\title{
AIDS, Intimacy and Care in Rural KwaZulu-Natal
}

A Kinship of Bones

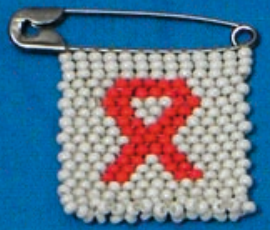


AIDS, Intimacy and Care in Rural KwaZulu-Natal 


\section{CARE \& WELFARE}

Care and welfare are changing rapidly in contemporary welfare states. The Care \& Welfare series publishes studies on changing relationships between citizens and professionals, on care and welfare governance, on identity politics in the context of these welfare state transformations, and on ethical topics. It will inspire international academic and political debate by developing and reflecting upon theories of (health) care and welfare through detailed national case studies and/or international comparisons. This series will offer new insights into the interdisciplinary theory of care and welfare and its practices.

\section{SERIES EDITORS}

Jan Willem Duyvendak, University of Amsterdam

Trudie Knijn, Utrecht University

Monique Kremer, Netherlands Scientific Council for Government Policy

(Wetenschappelijke Raad voor het Regeringsbeleid - WRR)

Margo Trappenburg, Utrecht University, Erasmus University Rotterdam

\section{PREVIOUSLY PUBLISHED}

Jan Willem Duyvendak, Trudie Knijn and Monique Kremer (eds.): Policy, People, and the New Professional. De-professionalisation and Re-professionalisation in Care and Welfare, 2006

ISBN 9789053568859

Ine Van Hoyweghen: Risks in the Making. Travels in Life Insurance and Genetics, 2007

ISBN 9789053569276

Anne-Mei The: In Death's Waiting Room. Living and Dying with Dementia in a Multicultural Society, 2008

ISBN 9789053560778

Barbara Da Roit: Strategies of Care. Changing Elderly Care in Italy and the Netherlands, 2010 ISBN 9789089642240

Janet Newman and Evelien Tonkens (eds.): Participation, Responsibility and Choice. Summoning the Active Citizen in Western European Welfare States, $201 \mathrm{I}$

ISBN 9789089642752 


\section{AIDS, INTIMACY AND CARE IN RuRAL KwAZuLU-NATAL}

A Kinship of Bones

Patricia C. Henderson 
Cover photo: Odette Herbert

Cover design: Sabine Mannel, NEON graphic design company, Amsterdam

Lay-out: JAPES, Amsterdam

ISBN 9789089643599

e-ISBN 97890 485I 4977

NUR 759

(C) Patricia C. Henderson / Amsterdam University Press, Amsterdam 2OII

All rights reserved. Without limiting the rights under copyright reserved above, no part of this book may be reproduced, stored in or introduced into a retrieval system, or transmitted, in any form or by any means (electronic, mechanical, photocopying, recording or otherwise) without the written permission of both the copyright owner and the author of the book. 
For the late Pippa Stein and my parents 



\section{Contents}

Acknowledgements 9

Preface $\quad$ I3

$\begin{array}{ll}\text { Introduction } & \text { I7 }\end{array}$

I. The Vertiginous Body and Social Metamorphosis 4I

The life and death of Nkosinathi Dladla 44

Symbolic investments in the body 5 I

Conclusion $\quad 56$

2. Mortality and the Ethics of Ethnographic Research 59

In the presence of death $\quad 59$

$\begin{array}{ll}\text { Theoretical pathways } & 64\end{array}$

Accompanying Mandla Shabalala in his illness 70

Conclusion 80

3. Children and Youth in Pursuit of Care 83

$\begin{array}{ll}\text { Introduction } & 83\end{array}$

The variable living circumstances of the children and youth of $\begin{array}{ll}\text { Amatikwe } & 87\end{array}$

The pain of mobility $\quad 95$

Expressive genres 99

$\begin{array}{ll}\text { Conclusion } & \text { IO2 }\end{array}$

4. Healers Negotiating the Local and the Global I05

Exploring healer narratives: Ntuthuko Hadebe Io8

Nonhlanhla Duma $\quad$ II3

Ties between the living and the dead, a conduit of knowledge II6

The politics of illness $\quad$ II9

$\begin{array}{ll}\text { Conclusion } & \text { I25 }\end{array}$

5. Love in a Time of Adversity $\quad$ I27

$\begin{array}{ll}\text { Part one } & \text { I29 }\end{array}$

$\begin{array}{ll}\text { Part two } & \text { I44 }\end{array}$

Conclusion $\quad$ I50

6. On Accompanying the Ill I53

Zinhle Vilikazi $\quad$ I57

Life experience and philosophy in relation to becoming a
volunteer

$\begin{array}{ll}\text { Home-based carers as brokers } & 167\end{array}$ 
The illegal sale of medication from a public health facility $\quad$ I70

Beginning a journey with antiretroviral therapies $\quad$ I72

Conclusion $\quad 176$

Epilogue I8I

Appendix: Interlocutors and Research Methods $\quad$ I87

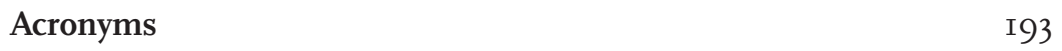

Glossary $\quad$ I95

$\begin{array}{ll}\text { Notes } & \text { 2OI }\end{array}$

Bibliography 225

Index 243 


\section{Acknowledgements}

Having completed a doctorate in social anthropology and a post-doctoral fellowship at an American university, I returned to South Africa in 2002 hoping to find work in the field of HIV and AIDS. With its overwhelming presence in southern Africa, the disease seemed to present one of the greatest challenges facing the newly formed South African democratic state. Its effects added an especially cruel burden to the multiple social and economic problems South Africa would have to confront. Through a series of serendipitous events, and in ways that suited my love of detailed anthropological and ethnographic research, I would indeed begin to work with people living with and alongside HIV and AIDS.

The years 2003 to 2007 marked a long and painful, yet rewarding journey in which I came to record individuals' experiences of living in the context of HIV and AIDS in Okhahlamba, a sub-district of KwaZuluNatal in the region of the northern Drakensberg. The period began with three years of intensive ethnographic fieldwork, followed by two years of writing an ethnography. My profound gratitude and respect are due throughout to Eleanor Preston-Whyte, the head of the Social Science Research Unit at the Centre for HIV and AIDS Networking (HIVAN) at the University of KwaZulu-Natal, who graciously oversaw the work, giving me freedom to devise plans for fieldwork and to explore, think and write as I chose. At the commencement of the project, Sean Jones not only recommended that I be approached to do the work, but wrote and submitted successful funding applications to the National Institutes of Health (NIH) and to the Rockefeller Brothers Fund, without which the research and the book would not have been possible. My heartfelt thanks are therefore also due to these funding bodies.

With regard to time spent in Okhahlamba, I cannot thank enough the many people whom I met, some of whose 'stories' concerning illness and care appear in particular chapters in the book. Each person whom I came to know has enriched my life in enduring ways. Through our exchanges in a time of AIDS, even in the midst of death and great sorrow, there was often a sense of beauty and human generosity: qualities that were interwoven with local cultural practice and ways-of-being. I do not mention the names of my friends in Okhahlamba in order to protect their identities. Yet I wish them to know that if I could, I would proclaim their names loudly. During my stay in Okhahlamba, several people I knew died of lesisifo (this illness, the local term most frequently used to refer to AIDS). What I have written is dedicated to their memory. 
The body of research I came to complete encompassed my relationships with home-based carers who had received some training in palliative care and who looked after the ill in their homesteads; with individuals suffering from HIV and AIDS and their families; a number of diviners and herbalists; and a group of young people from one settlement who had lost one or both parents through death. Without their acceptance and friendship, the work would not have been possible.

In particular, I would like to thank the home-based carers whom I visited in their homes and whom I accompanied on visits to some of their patients. My gratitude and respect are due to the few people who allowed me to accompany them in their journeys with the illness. I thank the healers whom I met for their wide-ranging philosophical discussions. The 3I 'Leaders of Tomorrow (LOT)' - young people whom I visited in their homes and at school in the community in which they lived - never failed to uplift me with their youthful exuberance. I thank them for their creativity, laughter, and performance, and for their playful description of anthropology as the exchange of unbounded 'stories about nothing'. I recall with happiness their accompanying me in walking the mountains to and from their homes.

On my arrival in the region, personnel at the then uThukela District Child Survival Project (TDCSP), a non-governmental organization (NGO) in Bergville, welcomed me and facilitated my relationship with home-based carers and young people. Special thanks are due to Monica Holst for agreeing that TDCSP form a research partnership with my own organization, HIVAN. Claire Kerry, who straddled both organizations, supported intervention efforts on the part of my research assistants and expressed frequent interest in the research.

Undoubtedly a great debt of gratitude is due to Phumzile Ndlovu and Zanele Mchunu, community workers and project managers at TDCSP, who became my research assistants and companions in the field. Without them, much of the work would not have been possible. I thank them for their growing enthusiasm for 'ethnography'; our often painful journeys together; and their hard work, unfailing support, and ingenuity in the face of many frustrations. Amagama abo adumile! (Their names are well known!) Xolisile Zondo patiently transcribed tape-recorded interviews in isiZulu and made excellent translations of them into English. Bernhard Gaede and Samantha Padayachee, friends and medical doctors in the region, sustained and stimulated me throughout my stay. Bernhard read what I wrote, distributing draft papers amongst hospital personnel. He kept me informed about developments at the regional hospital in relation to planning for the antiretroviral (ARV) roll-out, and when it was operational, of its progress. His unfailing enthusiasm for and knowledge of the region and its challenges continues to inspire me.

Deborah Heustice, who was our HIVAN project manager, visited Phumzile, Zanele, Xolisile and myself on numerous occasions, bringing her organizational skills and calm friendship to bear on the often painful 
experience of fieldwork. She listened unflinchingly as we unburdened ourselves of what we had witnessed in the lives of our ill and dying friends. Diane Merchant and John Robertson of the HIVAN administrative staff in Durban provided unstinting and efficient logistical support.

Friends who visited me in the field, or whom I in turn visited over weekends, mitigated the loneliness one sometimes feels when doing fieldwork and strengthened me in my purpose: they are Elizabeth Gunner, Jackie Chambers, Fiona Ross, Pamela Reynolds, Kelly Gillespie, Vivienne Bozalek, Abigail Baim-lance, the late Pippa Stein, Malcolm Purkey, Lyn Middleton, Vernon Solomon, Sue Mathieson, Tessa CarlyleMitchell and Terence Wulfsohn. I remember with fondness the visit of my sister, Elizabeth Marshall.

A number of people took care of me following a serious car accident in 'the berg'. I thank them all and in particular my indefatigable aunt, Shiela Henderson. She showed an unfailing interest in the work and frequently visited me in the 'hobbit's hut'.

Having left Okhahlamba at the end of 2005, in 2006 , a six-month research association with the Wits Institute of Social and Economic Research (WISER) enabled me to do some archival research and to write in a stimulating atmosphere. I thank Deborah Posel, and John Hyslop in this regard. A three-month summer residency at the Centro Incontro Humani in Ascona, Switzerland, provided a beautiful and peaceful setting in which to seriously write about the young people whom I came to know in the Drakensberg. I would like to thank Angela Hobart for her interest and generosity in hosting me, as well as Giovanni and Laura Simona for their assistance in Switzerland. In 2007, HIVAN, at the University of KwaZulu-Natal, remained an ongoing home in which to complete the manuscript.

Through their prolonged engagement with my work, Pamela Reynolds and Fiona Ross have offered intellectual companionship of a particularly 'fecund' sort, and have read, in stages, the entire manuscript. In particular, Fiona Ross and I have shared our work over many years. My deep gratitude goes to her for the mutual delight we take in discussions around our work, for her meticulous reading of my own, and for our deep friendship. S'bongile Maimane of HIVAN ably assisted me in checking the spelling of words in isiZulu that appear in the manuscript. Ngipabonga Ma! (Thank you mother!)

Apart from those already mentioned above, the following people read and commented on portions of the work at different times: the late Pippa Stein, James Williams, Aaron Goodfellow, Tamaryn Crankshaw, Claire Kerry, Fiona Scorgie, Helen Ibbitson, Beth Filiano, Deborah Posel, Lyn Middleton, Danilo Pedrelli, Tessa Carlyle-Mitchell, Sue Mathieson, Pareskivi Stavrou, Elizabeth Marshall, Jennifer Crouch, Deborah Heustice, Lesley Green, Steve Robins, Nicoli Nattrass, and Olga Nieuwenhuijs.

My research colleagues at HIVAN participated in lively and generous seminar discussions in response to the chapters of the book as they were 
written. Apart from colleagues whose names have already been mentioned, I would like to thank Gerry Coovadia, Steve Reid and Rob Pattman for incisive comments in the seminars they attended.

I am indebted to the inter-disciplinary Vimmin's Writing Group (VWG) for their lively response to my writing, and in particular to Astrid von Kotze, Ingrid Winterbach, Alleyn Diesel and Cheryl Stobie.

Yvonne Winters and Nellie Sommers of the Campbell Collections assisted me in tracing historical references to Okhahlamba. I owe thanks to the librarians of the Gubbins Africana Collection at the University of the Witwatersrand, and at the University of KwaZulu-Natal. At the University of the Witwatersrand, Carolyn Hamilton generously made some of her personal library of rare historical works available to me.

Thanks are also due to Trudie Knijn of the University of Utrecht and to others associated with the Amsterdam University Press, including Jaap Wagenaar, Saskia Gieling and Vivien Collingwood.

Lastly I thank my deceased parents, Olive and Gordon Henderson, who bestowed upon me a love of words, storytelling, and a certain obduracy of application.

Early versions of four Chapters of AIDS Intimacy and Care in Rural KwaZulu-Natal: A Kinship of Bones appeared in the following publications and in the following order:

For Chapter I: 2004. The vertiginous body and social metamorphosis in a context of HIV and AIDS. Anthropology Southern Africa, 27 (I\&2): 4353 .

For Chapter 2: 2005. Mortality and ethics of qualitative rural research in a context of HIV and AIDS. Anthropology Southern Africa, 28 (3\&4): 78 90.

For Chapter 3: 2006. South African AIDS orphans: Examining assumptions around vulnerability from the perspective of rural children and youth. Childhood, I3 (3): 303-327.

For Chapter 4: 2005. A gift without shortcomings: Healers negotiating the intersection of the local and global in the context of HIV and AIDS. Social Dynamics: Special issue: AIDS and Healing Strategies in South Africa, 3I (2): 24-54.

Patricia C. Henderson

November 2011 


\title{
Preface
}

\author{
Isihloko senkondlo yami sithi Gciwane Ndodana \\ kaNgculaza*
}

The heading of my poem, it says 'Germ, son of AIDS'**

Trinity Njoko Busisiwe

8 August 2005, performance

Philakahle Hall, Bergville

NginguGciwane Indodana kaNgculaza.

Iningi lenu liyangazi.

Kepha laba abangaziyo

abavumi ukuthi ngaziwe njengelunga

lomndeni wabo.

Kunalokho bayateketisa. Bathi ubaba wami uyindoda yale,

phesheya kwelase-Melika.

Kanti qha! Akunjalo.

Ngingu Gciwane, indodana kaNgculaza.

Kubobonke laba abasho

Njalo, akulutho.

Mina, Ngiyafika kubona.

Abanye baze bateketise ngayo.

Yonke indlela abuze ukuthi ngabe

ngighamuka kuliphi.

Ngithi nginendawo yokuhlala.

Ngihlala emzimbeni womuntu.

Nginethezeke ehotela lami, okuyigazi.
I am Germ, son of AIDS.

There are many of you

who know me.

Yet those who know me do not agree that I be known as one among their relatives.

There are those who waver. They say my father is a man from over there, across [the seas] from America.

But no! It is not like that.

I am Germ, son of AIDS.

There are those who always say,

it is nothing.

Yet, I arrive among them.

Others waver.

They ask in every way how it is

that I have suddenly appeared.

I say I have a place to stay.

I stay in the body of a person.

I am at ease at my hotel, the blood of a person. 
Ingani ngibangisana

nomakhelwane wami

abambiza uMasotsha oMzimba.

Phela, nginobhuti wami omcane.

Abambiza uZifo zoCansi.

Ingani uyena ongisizayo

ukuba ngibhebhetheke.

Ngigcwale izwe lonke

Ngomzuz' owodwa.

Ngihlasela ikhulu labantu

ikakhulukazi laba abazonda

umalume wami uKhondomi.

Kubona ngifika

sengiphindaphindeka

okwezinwele zomuntu.

Phela! NginguGciwane, indodana kaNgculaza.

\author{
Angikhathalele ukuthi \\ umude noma ingabe umfushane, \\ noma ingabe umuhle noma ingabe, umubi \\ noma ingabe umnyama noma ingabe \\ umhlophe, \\ noma ingabe upisigwili \\ noma ingabe uyisichaka, \\ noma ingabe uyisangoma, \\ noma ingabe udokotela. \\ Angikhathalele lutho. \\ NginguGciwane, indodana kaNgculaza.
}

It is because I contend

with my neighbour

whom they call, Soldiers-of-the-Body

[the immune system].

Indeed, I have my younger brother.

They call him Disease-of-the-Mat [of sex].

It is because he is the one who helps me so that I flare up.

I have filled all the land

in a single moment.

I attack hundreds of people

with a vengeance, especially those who hate my maternal uncle, Condom.

It is amongst them that I arrive

to return and return again

like the hairs [on the head] of a person.

Truly! I am Germ, son of AIDS.

I am not concerned about

whether you are tall or short,

whether you are beautiful or ugly,

whether you are black or white,

whether you are prosperous or

someone without money or livestock, ****

whether you are a diviner,

whether you are a doctor.

I am not at all concerned.

I am Germ, son of AIDS. 
Abanye baze bangakhela uhlelo

beluthatha esilungwini.

Onezinhlamvu ezithathu.

Bathi kukhona uA.

Bathi kukhona uB.

Bathi kukhona $u$ C.

Bathi uA uthi hlala ungayi ocansini.

Ulinde ukuthi uze ushade.

Bathi uB uthi thembeka

ube nomngane oyedwa.

Bathi uC uthi faka ijazi lomkhwenyana,

loyoke uKhondomi.

Ingani ngiyazi ukuthi

niyamzonda umalume wami

uKhomdomi.

Kulaba sengifike, qáthatha!

Angidlali.

Phela mina nginguGciwane, indodana

kaNgculaza.

He! He! Bamb' isandla sami, we maARVs.

Sihambe mina nawe.

Senza isethembiso, sami nawe

singefezwe umuntu

ngaphandle kwethu sobabili.

Engikwaziyo ukuthi wena ungumsizi wami

futhi ungumnyatheli, nomgxobi, nomcindezeli

womntwana ongahlelelwe emhlabeni onguGciwane

Mina nawe esithembisweni sami sathi

ebhuhleni nase bubini...

Siyofa silahlane.

Sihlukaniswe ukufa, impilo yami yonke.
Others have built a programme taken from the whites.

It has three syllables, three seeds.

They say there is A.

They say there is B.

They say there is C.

They say A means stay without sex, without going to the mat.

Wait until you are married.

They say B means be trustworthy having only one sweetheart.

They say C means put on the jacket of the son-in-law,

the one who is Condom.

It is because I know

you hate my mother's brother Condom.

I have arrived amongst those.

Qáthatha! ******

I do not play.

Truly I am Germ, son of AIDS.

He! He! Take my hand ARVs.

You and I go together.

We made a promise, mine and yours

that no person can fulfil

apart from the two of us.

What I know is that you are my

helper,

also a stamper, a trampler,

an oppressor

of the unplanned child

who is the virus.

You and I, in my promise we

have said

through good and bad

we will throw one another away

[only] when we die.

We will be separated by death,

for my whole life. 
Ngibonge kwabakwa Broad Reach ngokungi faka ohlelweni lwemishaguzo yama ARVs
I thank those of Broad Reach who have placed me within the programme of ARV medicines.

* Note that ingculaza, the Zulu word for AIDS, is also sometimes spelt with an ' $i$ ' as the last letter of the word. (See, for example, Roman Khumalo's poem in Chapter Two.)

** In isiZulu, gciwane is the word used to translate the English word, germ. It is also the term used for the human immunodeficiency virus. Its everyday meaning is 'a small particle floating in the air' (Doke et al I990: 236), or 'ash particles which rise when blowing fire' (Dent \& Nyembezi I969: 352).

**** Ukubhebhetheke means 'to spread fiercely as a fire' (Dent \& Nyembezi I969: 3II).

***** (Dent \& Nymbezi I969: 323).

***** Qáthatha is an ideophone of arriving (Dent \& Nyembezi I969: 464), of 'lightly dropping or falling down' (Doke et al I990: 690).

Possible roots of the word 'ingculaza': - ncu (adj.) very small, little; (i)nculu (noun) one who eats very little food; laza (v) turn sour, scatter as clouds, pass season without being covered by a bull, spread out in the wind as something running or flying (Dent \& Nyembezi ig69: 403). 


\section{Introduction}

From March 2003 to February 2006, I lived in Okhahlamba, a portion of the uThukela District in the South African province of KwaZulu-Natal. I had come to this mountainous region abutting the northern Drakensberg (Dragon's Mountain) to record the experiences of people living in a context of HIV and AIDS among African communities in the Ngwane and Zizi chieftaincies, and adjoining African freehold settlements. I hoped that whatever I came to write would reflect the concerns of rural people and would pay close attention to local ways in which the illness, through time, was folded into everyday life, as well as how people used language to reflect upon its devastating presence. My aim was to provide an ethnographic record of a particular period in which suffering from the illness was acute, and where, prior to readily available antiretroviral treatment, death was inevitable. In particular, I wished to trace repertoires of care outside of the formal institutional domains of hospitals and clinics, in order to show what people in limited circumstances brought to bear on the illness when there was little assistance forthcoming from the state. As it happens, the book spans a period in which antiretrovirals were initially unavailable, and moves on to a time when treatment became accessible in various ways. It therefore begins with the presence of overwhelming death and mourning, after which hope gradually became manifest in the recovery of a number of people through antiretroviral therapies and 'the return' of bodies they could recognize as their own - bodies that had recovered from a state of emaciation. ${ }^{\text {I }}$

Notwithstanding the 'crisis of representation' that has unsettled anthropology over the last 25 years by overturning the discipline's former claims to objective 'truth' (see Clifford i988, Clifford \& Marcus I986), I uphold the value of ethnographic study both as a research methodology and as an art of writing. In so far as ethnographic research implies protracted interaction with people over time, where an attempt is made to reflect a range of local views and practices pertaining to interlocutors 'in the field', it provides important records of and insights into the unfolding textures of everyday life (Fabian I983). These are textures that include the presence of the anthropologist, a presence that has its effects. In writing an ethnographic account of individuals' lives at a time of AIDS, I draw for inspiration on several ethnographies that in their diversity, attention to detail, styles of writing, and patient and subtle exegesis approach themes similar to those that appear in my own work. They are the themes of suffering, social and structural inequality, illness, violence, mourning, sensibility and intimacy (see Biehl 2005; Das \& 
Poole 2004; Csordas 2002; Petryna 2002; Das et al 200I, 2000, I997; Davis 2000; Desjarlais 1997; Nadia Seremetakis I996, I99I and Kleinman I995, I988). What I have written clearly reflects my own 'literary' style. Yet, in true empirical fashion, I have sought to record what was 'out there', as I encountered it, while at the same time acknowledging the shifting nature of the everyday. To my mind, far too little time is given to conducting rigorous research in dialogue with research participants across differing sectors of society in South Africa. The above omission comes to limit our understanding of political and ethical engagement with the world and its diversities.

\section{What's in a name?}

I begin the book with a brief exploration of a particular metaphor attached to the ways in which people living in Okhahlamba often spoke. It has to do with the increasing visibility of the outline of a person's bones as HIV and AIDS takes its alarming course. The title of the book draws upon a mother's account of the death of her daughter, and the textured implications of human bones within a living world, where care is brought to bear on the intrusion of illness, death and mourning. Having lived in Okhahlamba for a period of three years and having visited it intermittently for one year thereafter, a consideration of bones has come to hold for me a multivalent cluster of 'feeling-tones' related to sociality, relationship and intimacy, to the paring away of flesh, and to loss, mourning and death. Yet bones are also linked to the emergence of surprising strength. With their durability, they evoke memory, history and the endurance of people who have been dispossessed over protracted periods of time. All of the above thematic elements form ongoing 'threads' that weave their way through what I have written. They are the conduits through which I explore the overall theme of the book. They encompass the ambivalence of care that is both proffered and withheld in relations of intimacy, kinship and neighbourliness.

Turning to the mother's story of her daughter's death: in August 2003, on the day that she died of lesisifo (the name that is commonly given to HIV and AIDS in Okhahlamba), sensing that death was near, the daughter of a home-based carer thanked her mother, as she expressed it, for having 'touched [her] bones' while nursing her ('Ngirabonga ukungithinta amathambo'; 'Thank you for touching my bones'). The daughter insisted that if she had gone to a hospital to die, she would not have been touched in the same way. In 'touching her bones', her mother showed a love that neither quailed in the face of her emaciation, nor ignored it, but rather encompassed it through the movements of her hands. Her mother washed, cleaned and caressed her, giving shape to her daughter's suffering through feeling the outline of her bones, their density beneath her skin. It was an act that upheld the daughter's humanity and the va- 
lued threads of interconnection between herself and her mother in the face of death.

Luce Irigaray (I986) conveys the importance of touch that, although addressed to a body replete with flesh, is apposite in reflecting on the young woman's reciprocation and acknowledgement of her mother's love. In her words, touch becomes a medium of recognition, an act of giving that underscores social being as predicated on exchange:

Before orality comes to be, touch is already in existence. No nourishment can compensate for the grace, or the work, of touching. Touch makes it possible to wait, to gather strength, so that the other will return to caress and reshape, from within and from without, flesh that is given back to itself in the gestures of love. The most subtly necessary guardian of my life being the other's flesh. Approaching and speaking to me with [her] hands. Bringing me back to life more intimately than any regenerative nourishment, the other's hands, these palms with which [she] approaches without going through me, give me back the borders of my body and call me back to the remembrance of the most profound intimacy. (Ibid: 232-233)

At her own insistence some weeks before her death, the young woman asked her mother to accompany her in various tasks. In order to accomplish them, her mother carried her on her back like an infant to board a minibus taxi to travel to Johannesburg where the daughter had worked. Her mother then carried her through the streets of that city to the place where she had lived to recoup her possessions and important documents. On their return to Okhahlamba, her mother carried her to the relevant state department to secure the birth certificates of her children, documents that would be needed to obtain state grants for her children after her death. ${ }^{2}$

Through her actions, the mother re-enacted a tender and practical gesture related to childhood in most parts of the African continent, one in which a child is comforted, and in which the bearer's hands are freed for everyday tasks. The infant is cradled with a cloth against the back of the person carrying it, held with the front of its body against the warmth of an older person, its legs and arms embracing the contours of the carrier's body. In evoking the dependence of a child through the use of the word 'teta', yet using it in relation to her adult daughter who could no longer walk, the mother expressed how the act of bearing her child had become one imbued with sorrow. Instead of presaging a future of increasing capabilities, it pointed towards the ending of her daughter's life. The work taken up by the mother in relation to her daughter constituted their mutual attempt at ordering life in preparation for death. ${ }^{3}$

One social meaning of the mother's actions in touching her daughter indicates that although the flesh of a person undergoing AIDS falls away, the body's frame, the skeleton, with each bone linked to another, becomes a metaphor for the insistence on a certain coherence of person- 
hood in a dying person. A defiant insistence on the coherence of personhood on the brink of death points to the conviction that the dead are not utterly lost to the living. In Okhahlamba, burial of the physical body enables the person, after a certain lapse of time, to become an ancestral shade linked once more to the living. Touching the skeletal foundation of a person through skin, where the flesh has withered away, points therefore to both acknowledging death within life and the future possibility of the re-emergence of a form of life within death.

The South African novelist, Phaswane Mpe (200I), in Welcome to Our Hillbrow, depicts the lives of several characters, some of whom come from a rural place not unlike Okhahlamba, who have found their way to the city of Johannesburg. Amidst the maelstrom of city life, the novel encompasses the presence of HIV and AIDS and the way in which the flowering of young people is destroyed through premature death. Refentše, the person in whose voice the novel is written, refers to the girl he loves as 'the bone of my heart' (ibid: 24). It is a metaphor that projects, in his case, the wish for durability within an intimate relationship, the longing for a point of stillness in a social world rent with unpredictability. It strives for solidity where little coheres. Another person encompassed as the bone of one's heart renders visible a longing for the intense, emotional weight of relationship, for a certain interdependence. It is an idea that holds the importance people have for one another. Granting another person the centrality and weight of 'a bone within one's heart' cannot, however, anchor them unequivocally to the self. Herein lies the pain of relationship, the ways in which, for example, in Mpe's novel, Refentše and his lover, Lerato, find themselves unwittingly betraying one another. Another as a bone within one's heart emphasizes, too, the ways in which a person who has died lingers in the memory of the living with an obdurate weight. Another's bone, as a hook within the heart, becomes a metaphor for mourning, as well as the capacity for inflicting pain on those for whom one cares.

An awareness of bones, and the touching of bones issues into being a sense that death has crossed into the fabric of social life and points to the ways in which death within life occupies the space of the living. ${ }^{4}$ The mother's account of her actions in touching and accompanying her daughter in the face of death demonstrates a quiet resolve to keep the unravelling effects of death at bay. Yet inevitably, within the trajectory of the illness, the approach and eventuality of death profoundly unsettles social life. The story I have told reiterates the major themes within the book: those of care, intimacy and relationship in a time of AIDS, where the latter processes are grounded in the human body. 


\section{Body, illness and sociality}

I revisit Trinity Njoko Busisiwe's poem from the book's preface in order to begin reflecting on the intertwining of body, illness and sociality. Within the poem, the social effects of AIDS mirror and exacerbate already existing fault-lines in the social world. And in being faced with bodily disintegration, sociality, in turn, 'finds a mirror for itself'. ${ }^{5}$

In August 2005, after some months of having experienced the effects of antiretroviral therapy, Trinity wrote her extraordinary poem as a marker of her own relationship with the illness and with the medication. She performed it for a general home-based carers' meeting at which I happened to be present. In her poem, the virus and the disease are folded into everyday life through the use of metaphors of kinship, blood and relationship.

The kinship terms she uses draw attention to the way in which HIV and AIDS has come to dwell within families and within neighbourhoods in Okhahlamba, ${ }^{6}$ to insert itself in relationships of intimacy and to take up 'luxurious' residence in the bodies of persons. The juxtaposition of metaphors of illness and relationship exacerbate ongoing friction within spaces of intimacy and genealogy, in which ideals attached to notions of kinship are profoundly shaken and yet reiterated in uncanny ways.

HIV, like an unruly relative, a pugilist, has arrived, and as Trinity expressed it, has jumped down lightly within the space of family, ready for a fight. As it is ideally imagined, the space of family offers nurturance, protection and continuity, attributes that are hard to sustain in the context of migrancy, mobility, separation and impoverishment. The family is always a site of struggle and pain, notwithstanding ideals. The arrival of AIDS renders bare the tensions and fault-lines of family, so that the space of family becomes increasingly acrimonious and, indeed, murderous, because it is linked to death. Just as difficult unruly relations cannot be utterly repudiated, because claims of lineage and blood seek to cement relatedness, so the presence and the effects of the virus within the body of a person cannot be wished away or denied. In this way, the virus takes on the attributes of a difficult relative, one who disrupts normative ideals and whose influence is deeply felt. So, too, the effects of the virus are scored within the bodies of individuals, and are witnessed within the parameters of family and beyond. In a world where relationships of intimacy and of kinship bear the weight of structural forms of violence growing out of particular political economies and violent histories of dispossession within South Africa, the ways in which relationships do not cohere and begin to unravel provide, in turn, a set of metaphors with which to describe the effects of the illness.

The body in Trinity's poem becomes a dwelling, a house, a hotel, in which a pair of belligerent brothers unites against the outside world: Germ, the virus, takes up residence in his 'hotel', the blood of a person; his younger brother, Disease-of-the-Mat (referring to sex) causes the dis- 
ease to flare up, as in a fight. Germ and Disease-of-the-Mat are particularly keen to fight those who 'hate' and reject their maternal uncle, Condom. The brothers attack their neighbour, Soldiers-of-the-Body (the immune system) without reservation. The accumulative instances of their prowess are as numerous as the hairs on a person's head. Through the juxtaposition of the interior of the body with fraught social relations, Trinity's poem has captured the ways in which the biological folds into the social, and the ways in which the body holds a host of metaphors for the organization and disorganization of social life. Whereas the two brothers are unapologetically indisposed to their neighbours, their maternal uncle, Condom, is a benevolent relative when engaged with positively. Local values attached to a maternal uncle imply that he is a relative from whom one can demand certain generosities, with whom one can be open about sexual matters, and from whom one can, within limits, demand various goods. Maternal uncles are concerned with the continuation of threads of social life and with the well-being of their sisters' children, and they often play a loving and mediatory role between families. ${ }^{7}$

Bearing in mind both the mother's experience of her daughter's death and Trinity's poem, I would like to suggest that in contrast to the ways these women have confronted and reflected upon the embodied experience of AIDS, few academic studies have closely examined the excruciating suffering that individuals undergo through the illness, and in terms that they would recognize. Given the extreme ways in which AIDS systematically attacks the body so that it is worn away, it is not surprising that those confronted with a person who is afflicted with the disease may experience fear. People suffering from AIDS also often experience radical alienation in relation to their own bodies. It is thus partially the corporeal challenges of the illness, not only for people who are dying, but also for those who witness their demise and who may be responsible for their care, that are linked to the ways in which people may reject or isolate a person undergoing AIDS.

In relation to healing, and in ways that are equally applicable to illness, Thomas Csordas (2002: 3) stresses the importance of turning to phenomenology and the idea of embodiment, 'insofar as it speaks of immediacy, indeterminacy, sensibility - all that has to do with the vividness and urgency of experience' (ibid). In writing of individuals in relation to HIV and AIDS in Okhahlamba, I seek to remain close to the 'urgency' of their experience. Csordas further suggests that language constitutes an embodied gesture towards exploring experience, something that resonates profoundly with both the bravery of a daughter in thanking her mother for touching her bones, and in the sardonic and socially aware language of 'Trinity's poem, in which, for example, her 'love relationship' and 'marriage' with antiretroviral medication and the illness have come to imitate the social equivalent. ${ }^{8}$ For Csordas (2002: 4), language becomes 'the enactment of a mode-of-being in the world', and for Maurice Merleau-Ponty (I962: I96 citing Goldstein I933: 496), 'a manifestation, 
a revelation of intimate being' and of the individual's link to the world and to others. In the book, I plan to show how the immediacy of body and emotion are linked to language and social relationship in ways that sometimes cohere and sometimes unravel.

\section{Sketching the parameters of care}

In the mother's story about her daughter, I have introduced three aspects of care, as I encountered them in Okhahlamba. They relate to what it means to touch and be touched, to carry and be carried, and to exchange speech in the context of illness. Each strand, grounded in actions and issuing from the body, bears philosophical possibilities.

As we have seen, touch is not simply involved in the mechanics of daily care and cleanliness, but becomes a subtle conduit of love, affirmation and recognition. The act of carrying a person conveys not only the literal act, but what it means to accompany and to lend one's bodily forces to another, who because of illness can no longer accomplish journeys or actions on their own. The notion of accompanying a person raises the question of how this may be done respectfully. I have also intimated that careful and caring language is a learnt and unfolding process of exchange between an ill person and his or her associates and carer(s). It goes without saying that the above aspects of care are linked to intimacy and ethics. Inherent in all such 'actions' are the possibilities of refusal, rejection, abuse of power, and the unravelling effects of the intrusion of visceral responses to social life.

Reflecting on the multiple implications of the words 'to touch', 'to carry' and 'to care' in isiZulu, I bring forward some of the multivalent meanings attached to the actions they evoke. These terms also hold presumptions of hierarchy that, although not inevitable in the ways they may be qualified in use and in social relationship per se, allow an appreciation of how care can be permeated with unequal relations of power and forms of condescension.

Local implications of touch (ukuthinta), for example, are multi-layered in additional ways to those mentioned above. In saying that they have touched a person, healers do not only mean literal touch, but that their touching, their interaction with an ill person and his or her body, has effected a change, a transformation in his or her way-of-being, a 'cure'. The latter ideas are not unlike Irigaray's conception of touch as a form of nourishment (see page I9). A healer's touch, bringing with it the influence of the ancestral shades who work through them, shapes the living. It becomes the social conduit through which ancestors, although deceased, are able to reach the living. Touching, in the latter sense, is to reconfigure a person's physical, emotional, and social being in an act of reshaping, of making, which involves the social weight of predecessors. 
The verb 'to carry' (ukuphatha) literally means to carry with the hands, but with the addition of appropriate adjectives, to treat a person in certain qualitative ways, whether well or badly. Within its horizon of meaning lies the notion of power, in that a ruler or a carer is configured as being in charge of people whom they command, or for whom they care, or both. Doke et al (I990: 649), in relation to the verb phatha, claim that it means, on the one hand: 'to handle and to hold; to feel and to touch; to carry and to contain'. On the other hand, the word implies: 'to treat, to deal with; to engage in; to manage, to superintend, to be in command of, and to take charge of'.

Lastly, 'to care' (ukunaka) connotes concern for a person, but also the action necessary in taking care of them. As vulnerability is assigned to the very young, the elderly, the disabled, the chronically ill and otherwise sick, the word 'umnakabaphath', meaning 'that which is of concern, or the person who is of concern to those in charge', derives its weight in relation to care for the young. In doing so, it refers to a baby or very young child who needs special attention and care from those responsible for it. In the context of widespread illness in Okhahlamba, home-based carers extend the word's applicability to encompass their relation with the chronically ill. AIDS sufferers share certain vulnerabilities with young children, in that they require special, ongoing care and consideration. Implicit in the latter usage of the word is the responsibility borne by caregivers in relation to the ill. It points to the way in which those who care for the ill may assume power over them. Its use is a demonstration of the way in which repertoires of care may be socially extended, the point being that the dependencies of and obligations to childhood are always embedded in social relations, even those ostensibly of adults.

Many home-based carers referred to ill people whom they tended as 'iziguli zami (my ill ones), a less hierarchical naming. As Arthur Kleinman (I988) argues in his now classic book, The Illness Narratives: Suffering, Healing and the Human Condition, the use of the word 'illness' as opposed to that of 'disease' comes closer to the lived experience of those who are ill. By using the term, his aim was to 'conjure up the innately human experience of symptoms and suffering'(Kleinman I988: 3). Similarly, home-based carers, in referring to their patients as 'my ill ones', seek to underscore the journeys they have taken together and the ways in which stories and experiences of illness have been shared.

Given what I have written above, care of the individual, whether by the self, within the family or within a neighbourhood, does not comprise a distanced set of procedures, those that might, on one level, encompass the professionalization of care: the sets of methodical, standardized acts that are sometimes striven for within a hospital setting, for example. Rather they bear the emotional weight invested in bodies and gendered subjectivities. They are proffered or withheld within the social play of such relationships, and in the face of challenges to social expectations embedded in relatedness in the presence of the disease. In the fault-lines 
that HIV and AIDS throws up within differing forms of relatedness, recognition of an ill person in the specificity of their illness is not always forthcoming. A lack of recognition precipitates particular kinds of alienation, and even social death. A person who is ill may come to know what it is to remain unseen within a space of relatedness that in other circumstances would offer a degree of recognition. It is within spaces of alienation that aspects of care related to speech, for example, become poisonous or trite, and in which silence may seem apposite. ${ }^{9}$

Everyday practices of care may also assume invisibility because they are seldom publicly valued and are taken for granted. It is clear that women and girls carry out most immediate activities around care in relation to cooking for, cleaning, feeding and accompanying the ill. The care offered by men is not as 'hands-on', but is nevertheless conveyed through visiting, speech, and through leading funeral proceedings, where the qualities of the deceased are often praised. Repertoires of care are therefore gendered, infused with power, and woven into the textures of subjectivities. To a degree, assumptions underlying care and the inequalities of power within relationships of intimacy are forced into visibility through the disruption of the disease.

Although I draw on a wide and eclectic range of philosophical and anthropological literature to assist me in thinking through ethnographic details in the book, I mention here the two writers who have helped me most in considering care in its ambivalence. On the one hand, I draw on the loving and exacting philosophy of Emmanuel Levinas (200I: 56-III), with his concern for ethics and responsibility. I draw on his founding philosophical notion that sociality is prior to any epistemology, and that before we are subjects we are already social beings. This is pertinent to the idea of what passes between a person in need of care and a carer, in that Levinas is at pains to face ubiquitous human vulnerability and mortality, attributes of humanness that cannot be easily understood or described by another. It is the care with which he sketches out how people may approach one another that I find has resonance with my aims. In particular, Levinas' notion of solicitude (Levinas 200I: I08) describes a form of respectful attention offered to another, one that is open to surprise and does not perform the violence of seeking too quick a definition of the other or of their experience. His ideas have resonance with the local South African philosophical notion of ubuntu, where a person is a person by virtue of other people, and where one cannot claim selfhood in the absence of threads of inter-relationship. Within the horizons of his philosophy, we come into ourselves through our relationships with others. Levinas' (2002: 57) description of suffering as being a form of solitude, of being cut off and shut up within the self, suggests ways in which people may enter a space of both physical and social pain, including social death - a set of observations on suffering that are particularly pertinent to people afflicted with AIDS. 
On the other hand, I draw on the incisive reflections of the psychoanalytic philosopher Julia Kristeva (1987, 1982), and her meditations on both horror and desire. Her notion of abjection (Kristeva I982) has aided me in approaching unbounded visceral responses in relation to illness, bodily fluids and the viscous. She describes the horror of the abject, attaching to such substances that are profoundly disturbing because they unsettle ontologies of solidity. In a superb rendition of Kristeva's ideas and drawing on the anthropologist Mary Douglas' writing on pollution, Elizabeth Grosz (1994) explores the body's permeability as a disturbance of the ordered body. The above set of ideas has assisted me in approaching the immediate, sensorial experience of undergoing and witnessing AIDS, with its unrelenting attack on the human body and its transformation of the solidity of flesh into its demise, often into the fluid. Kristeva's (I987) exploration of desire has helped me to approach the affective dimensions of relationships; for example, in relation to the discovery that we find ourselves already in love (Kristeva 1987). Being in love is not something that we choose, but something that becomes tangible through heightened bodily 'symptoms'. In rationalized responses to HIV and AIDS, including the formulation of prevention campaigns, we have often forgotten the 'unruliness' of desire. To conclude, both Levinas and Kristeva have assisted me in beginning to sketch out what I call an anthropology of intimacy - one predicated on a phenomenology of embodiment (Csordas 2002, 2000; Lock \& Farquhar 2007 and MerleauPonty 1964, 2000).

\section{The study in relation to local literature}

In articulating the particular contribution of my work in relation to other literature, I do not claim to draw on an exhaustive set of references dealing with HIV and AIDS, as there is now a vast and diverse body of research in South Africa, much of which has little resonance with my own.

In what may broadly be termed the social sciences, the earliest works on HIV and AIDS in the region were prognostic in nature, drawing on studies in relation to the pandemic in America in the I980s and dealing locally with its unprecedented scale and possible societal outcomes (Abdool Karim et al I992a, Abdool Karim S. \& Abdool Karim Q. 2005, Barnett \& Blaikie I99I, Barnett \& Whiteside 2002, Dorrington 200I, Dorrington et al 200I, Dorrington, Bradshaw \& Budlender 2002, Dorrington, Moultrie \& Timaeus 2004, Whiteside \& Sunter 2000). Researchers created numerical projections and surveys of the epidemic, and called for prompt responses in containing it, pointing out the multiple social, economic, and political problems that were foreseen as developing in its wake (Sunter \& Whiteside 2000). ${ }^{10}$ Their predictions, based on generalized theories of economics, psychology, family and sexuality, bore little relation to how people lived 'on the ground', to the social nuan- 
ces of everyday life, or to the weight of history and its effects on the provision of health care and on local views concerning illness. Perhaps many would argue that given the seriousness of the epidemic and the importance of galvanizing society's forces to meet its challenges, there did not exist the time or space for longitudinal qualitative research about people's experiences around living with and alongside HIV and AIDS. Yet such studies, including my own, become increasingly important where researchers are now hard-pressed to understand why prevention campaigns and attempts at promoting changes in sexual practice to mitigate risk have largely been unsuccessful in South Africa.

If early studies concerning HIV and AIDS were broad in scope, more recent research is increasingly pointillist in dealing with specific aspects of intervention, prevention, and social issues around antiretroviral treatment regimes. Here, for example, work within the overall field of sexuality, 'behaviour modification', violence and risk may focus in on the expansion of safe-sex methods, informed by a recognition of gender inequalities and power differentials within a predominantly patriarchal society. ${ }^{\text {II }}$

Some studies of a more anthropological nature have emphasized the emergence of localized explanatory frameworks for the disease at odds with common universal claims. Peter Geschiere's (I997: 2I2) conception of witchcraft as the dark side of kinship is in sympathy with what I have written (see Chapter One). He argues that bewitchment 'expresses the frightening realization that aggression threatens from within the intimacy of the family', and upholds the view that 'the discourse of bewitchment includes the effort to maintain relations despite its threat' (my own emphasis). In citing the Douala proverb, 'One must learn to live with one's sorcerer', he provides an exemplar that resonates with the ambivalence of care within relations of intimacy, as I have outlined in the previous section. Geschiere concludes in ways that are apposite for Okhahlamba, arguing that in Cameroon, families remain the 'cornerstones of life' and that individuals cannot live without their intimacy - an intimacy that includes jealously and aggression. ${ }^{\text {I2 }}$

Careful and more 'anthropological' work that has bearing on HIV and AIDS and that pays attention to cultural specificities and local ways-ofbeing may be broadly placed within a field of studies relating to sexuality, or the play of intimate relationships in relation to gendered identity formation. ${ }^{\mathrm{I}}$ Because these studies pay attention to the unfolding of local worlds and their imaginaries, as well as their location within changing historical and material circumstance, they assist in problematizing many assumptions in standardized AIDS research.

Such studies include the demographer Mark Hunter's (2007, 2005, 2002) exploration of masculinity and the materiality of everyday sex in several communities along the north coast of KwaZulu-Natal, and Fiona Scorgie's $(2004,2002)$ measured work based on prolonged anthropological fieldwork in the Centocow region of southern KwaZulu-Natal, con- 
cerned with the construction of contemporary identities among women and girls. The significance of Hunter's work is to trace changes within South Africa's political economy, straddling both apartheid and postapartheid periods, linking them with changes within forms of exchange in relation to intimacy and sexuality and their accompanying discourses. With the globalization of South Africa's economy, he shows (Hunter 2007, 2002) how increasing impoverishment and diminishing levels of employment for both men and women have been accompanied by the formation of multiple sexual partnerships, entangled with forms of material and affective exchange. Hunter undercuts moralizing discourses in relation to sexuality, as well as a number of terms used in AIDS research that have limited applicability - 'prostitution' being one, for example. ${ }^{\text {I4 }}$ In my view, transactional sexual relationships have long been established in South Africa due to entrenched labour migration. Women in Okhahlamba, for example, explained to me that when husbands neglected to send grandmothers, mothers and themselves remittances from their places of employment, or 'disappeared' into the cities never to return, they survived through 'strengthening the fence', a metaphor implying the taking on of lovers.

Scorgie, in turn, explores the revival and growing popularity of virginity testing as a local response to HIV and AIDS within the framework of a nostalgic revisiting of the past, in which women and girls strive to reconfigure everyday experience. ${ }^{15}$ Such rituals assume significance in the context of everyday circumstances, where women in the region have come to know the material strains of raising children and grandchildren in often multi-generational households of grandmothers, their daughters and their daughters' children. She explains how a broad spectrum of women's practices nevertheless take place within patriarchal frameworks in which the sexuality of men, as well as their shared culpability in spreading sexual disease, is omitted from scrutiny, and where the most vulnerable members of society, young girls, are publicly held responsible for controlling sexuality through abstention, and for thus upholding 'purity'. ${ }^{16}$ My work is similar to that of Hunter and Scorgie in that it seeks to pay attention to the details of everyday life outside urban metropoles as well as to the terms and practices employed within that life, within relationships of differing kinds, and within a context of widespread death. It differs from their work in that my ethnography is made up, in the main, of detailed individual stories that show how common local practices may be taken up in differing and multiplicitous ways.

More recently, Didier Fassin (2007) and Nicoli Nattrass (2007), although from very different perspectives and epistemological standpoints, have sought to come to grips with the parameters of the erstwhile South African AIDS debate, particularly in relation to what was termed 'denialism', as it circulated in public discourse on the part of the then South African president, Thabo Mbeki and his health minister, Manto Shabalala-Msimang. Fassin and Nattrass have both thoroughly docu- 
mented the latter debate in important ways, including the history of differing approaches at the level of the state's response, and in relation to bodies of scientists and HIV and AIDS activists, where social movements, most importantly, the Treatment Action Campaign (TAC), took up strategies similar to those pertaining to the struggle against the apartheid state in securing antiretroviral treatment for South African citizens.

Nattrass's book traces the consequently rocky formulation of initial AIDS policy in South Africa, together with the courageous fight for state provision of antiretroviral treatment on the part of activists. Due to mounting TAC mobilization, pressure from the trade unions in South Africa and a cabinet revolt in October 2003, the health minister was forced to formulate a plan for the state rollout of antiretroviral treatment. However, because of the generally slow pace of the rollout, by the end of 2005 , fewer than a quarter of those who needed antiretroviral therapies were receiving them (Nattrass ibid: 5 ). Nattrass concluded her book by celebrating improved national AIDS policy, as laid out within the Department of Health's 2007-20II, strategic plan. ${ }^{17}$ In relation to my own ethnography, it is important to recall that antiretroviral rollout through the local state hospital in Okhahlamba only began in March 2005. Prior to that, fewer than a hundred patients had received the medication that had been made available to them through an NGO.

In the field of medical anthropology and as a medical doctor, Fassin's (2007) wide-ranging work explored the specific logics of a multiplicity of responses to and experiences of HIV and AIDS in South Africa. His aim was to soften the derisive, polemical standoff between 'denialists' on the one hand, and activists, scholars and scientific bodies on the other. Through an examination of histories of racial inequality, domination and dispossession, and their attendant discourses, he explained the ways in which Thabo Mbeki's stance became comprehensible, though not excusable. He likewise strove to show that scientific bodies were not only purveyors of truth. The fact that treatment regimens were improved over time indicated their processual nature, something often obscured in presenting medical science's 'inviolable face'. In addition, scientific bodies, as part of colonial histories that characterized the ill within dominated populations in racist terms, practised health care in discriminatory ways. Fassin drew on the work of historian, Shula Marks (2002, see also Walker, Reid \& Cornell 2004) to show how racial inequality and poverty in South Africa shaped the epidemiological distribution of disease in earlier years and was equally important in relation to HIV and AIDS. ${ }^{\mathrm{I}}{ }^{8}$ However, as Steven Robins (Cape Times 2007: 9) pointed out in a critical review of Fassin's book, linking disease to political economy, underdevelopment, poverty and ideology within an African context was nothing particularly new (see, for example, Kark I950, I949). He concluded that constituencies challenging President Mbeki's 'denialism' were profoundly aware of the weight of histories in relation to illness, yet recognized the importance of promoting antiretroviral therapies that were 
known to prolong people's lives. In my work, I too suggest how illness cannot be encompassed without its relation to painful histories (see in particular Chapter Four).

Turning to my own approach in the book, I pay close attention to language use in Okhahlamba and to rituals concerning relationship, death and mourning in all their variability. In doing so, I do not claim that these are unchanging, yet I argue for the importance of recording cultural specificities that are interwoven within the everyday and that are often excluded from broad-based descriptions of social worlds and their structural underpinnings. I argue that there exist aesthetic possibilities within everyday life that provide repertoires through which people respond to adversity, and that guard against their worlds being defined in terms of unmitigated deficiencies. In suggesting the latter points, I do not mean to exclude the sometimes oppressive contours of cultural practice, nor its often hybrid and multifaceted nature. ${ }^{\text {I9 }}$ I am therefore concerned with the mobilization of cultural and social ways-of-being in relation to HIV and AIDS and with the intimacy of care. I consider different parameters of care, ranging from the most physically immediate to the more philosophical and ideal. Care embedded in social relationships emerges in the exchange that is inherent in them: exchanges of sexual fluids, the offering and acknowledgement of services, the exchange of gifts, the exchange of words, and the generation of affect or emotional investment. The latter are exchanges that may be refused also. I describe a full range of care: parental, sexual, intimate, that encompassing friendship, and the difficulties associated with each. As I describe it, care is not one thing, nor is it stable. It is ongoing work, a commitment in which some people succeed and others fail to sustain one another and themselves, and in which the state is sometimes absent and sometimes present, but seldom reliable. In addition, in attending to language, I show how people use poetry, imagination, desire, and fantasy to recreate worlds that are nevertheless fragile. The book is about living in the fullness of language and relationship and with the recognition of their shortcomings. It is about prolonged struggle: the coming and going of care, the efforts to sustain, the sadness when it fails. It charts the poetic as a mode of the everyday, not in the sense of transcendence, but in the sense of a taken-for-granted way of relating in the world that sometimes succeeds and sometimes places burdens that are too onerous on the living.

\section{Of place and history}

Okhahlamba is characterized by particular forms of inequality that bear the trace of history, inequalities that are marked in how land is inhabited and how different regions are still largely occupied by different racial groups. On its north-western borders, the towering peaks of South Africa's most significant mountain range, the Drakensberg, rise in places 
higher than 3000 metres above sea level. The region is made up of communal lands abutting the mountains held by the Ngwane and Zizi chieftaincies; eleven freehold areas in which African people live; large commercial, mostly white-owned farms on which maize, wheat and beans are grown and where cattle are reared; and a number of mountain resorts frequented by wealthy tourists. Rivers in the area include the Thukela and the Mlambonja, which have their headwaters in the mountains. Winterton and Bergville, two small towns, provide a limited number of services. The closest major towns are Escourt and Ladysmith, both outside the sub-district. In 2003-4, doctors at the local hospital estimated the population of Okhahlamba to be in excess of the 1996 census figure ( 136,000$)$, at approximately 150,000 .

I now turn to a brief overview of how the Ngwane and Zizi chieftaincies and the African freehold settlements in Okhahlamba came to be, as it was among people living in these areas that I conducted my research. I do so to trace forms of dispossession and increasing impoverishment, realities that are neither unrelated to the state of health of the many inhabitants of Okhahlamba, nor to the ways in which issues of health are considered and interpreted.

In the I8Ios, the Ngwane people, who lived on the banks of the White Mfolozi River in a part of what was to become the Zulu kingdom under Shaka, were displaced by powerful clans who seized their cattle. They travelled over 200 kilometres to settle in the upper Thukela River region in the foothills of the Drakensberg (Laband I995: I5-16). The clans that they, in turn, had scattered came to offer Matiwane, the Ngwane leader, their allegiance (Wright I989: 220). These included the Zizi people, who had lived in the region of the upper Thukela for over two hundred years (Wright \& Mazel 2007: 73, Bryant 1929: 335). In I822, the Ngwane were displaced once more when their cattle were seized by Shaka's general, Ndaba (Web \& Wright, I978: 6, Bryant 1929: 139). Having climbed the escarpment, they attempted to secure land and cattle and eventually travelled a considerable distance to the south west into lands occupied by the Mthembu, in what is today the Eastern Cape. ${ }^{20}$ In August I828, the Ngwane were resoundingly defeated at Mbholompho by a Cape colonial force made up of British, Boer, Mthembu, Gcaleka and Mpondo conscripts and levies (Wright I989: III). After his father's death, which followed shortly on the defeat at Mbholompo, Zikhali, Matiwane's son, returned to the Drakensberg to reconstitute the Ngwane presence there.

In I843, the British imperial government annexed a swathe of land to the west of the Zulu Kingdom, including the northern Drakensberg, to form the colony of Natal. Competition over land between the African majority, Boer pastoralists who had entered the region in I837, and English farmers who were apportioned land in the I840s and 50s, became regulated under British colonial rule. In I849, the Hlubi, Ngwane and Zizi occupation of lands along the northern Drakensberg was formalized 
as part of a reserve system to be administered through indirect governance (Brookes i987: 60). ${ }^{\text {2I }}$

Although there were approximately I০০,০০০ Africans living in the colony of Natal, the bulk of the colony, including the best farming land, was made available to approximately Io,000 white settlers (ibid: 60). The Upper Thukela locations formed a buffer zone between white settlers and the displaced San and Basotho over the mountains, who had become adept cattle rustlers (Wright \& Mazel 2007: 23-48). ${ }^{22}$ By the I86os, an active peasantry had emerged among some Ngwane and many of their neighbours among the Hlubi, with wealthier families selling surplus grain to colonists. ${ }^{23}$ Pressure was soon exerted from white farmers to end such competition and to ensure a supply of labour on their farms. By the I870s, men across the region had begun travelling on foot to the diamond mines in Kimberley, some 600 kilometres away, to secure goods and money to pay a number of particularly unpopular taxes, including a marriage tax.

Langalibalele of the Hlubi, whose people too often ignored the strictures of the colonial government, including the injunction to register guns purchased through working in the diamond mines, encountered the punitive face of the colonial state, and his people were completely subjugated. At his trial, described as a travesty of justice by the Anglican Bishop of Natal, John William Colenso, Langalibalele was accused of treason and imprisoned on Robben Island, and was later sent into exile in the vicinity of Pietermaritzburg, the capital. In the initial clash with colonial forces, many of his followers were killed (Guy I983: 202), with the surviving women and children forced into indentured labour on white-owned farms around the towns of Escourt and Pietermaritzburg (Wright \& Manson I983: 4I). The Ngwane were not unaffected by these momentous events, which partly explained their reluctance to take overt part in the I906 Bambatha uprising against the imposition of furthers taxes, thirty years later (Guest I962). ${ }^{24}$

Until the I88os, homesteads in the reserve areas of Natal were able to sustain themselves and to pay taxes through the selling of surplus crops or animals, or through wages accrued in sending young men intermittently to work in towns or on white farms. Increasingly, however, the reserves became overcrowded, and the majority of people sought work elsewhere for longer periods. Lands available for cultivation and cattle herds became smaller, having been decimated during the I896-7 rinderpest epidemic (Wright \& Mazel 2007: I24).

In I9I9, the Industrial and Commercial Workers' Union (ICU) was founded among dockworkers in Cape Town. From I927-28, farm workers in Natal began to join the union under the charismatic leadership of its national secretary, Allison Wessels Champion. ${ }^{25}$ The ICU, linked with emerging forms of nationalist thought and the hope of land restitution, had offices in the towns closest to the Upper Thukela Locations. Reaction from the white population was swift. In Bergville, for example, 
thirty Natal Carbineers conducted a raid on the union offices, burning all documentation and assaulting its office bearers (Wright \& Mazel 2007: I22-23).

During the I920s, 30 s and 40s, migration to the major cities of South Africa to find paid work had become a way of life for the majority of men living in the reserves and for an increasing number of women. Mechanization on white-owned farms in the I950s and Gos led to the eviction of African labour-tenants who had exchanged labour on a six-month system for small wages and the right to erect homesteads on farms, with limited access to fields for cultivation and grazing land for their animals. Many evictees sought land in the already overcrowded reserves and as lessees on privately owned land bought by mission-educated Africans in the late Igth century (Surplus People Project (SPP) I983). Under the apartheid government that came to power in 1948 , the Bergville area was one of the first districts where labour tenancy was prohibited by law (ibid: 293). From I960 to I983, 300,000 farm workers were evicted from farms in the province (Platzky \& Walker I986: I0). Under the apartheid regime's forced removal policy and its attempt to consolidate ethnically separate bantustans or homelands, 60,000 people from the Ngwane chieftaincy were threatened with removal into the neighbouring valleys of the Ngwe and Hlubi. Met with fierce opposition, and taking into consideration the considerable costs of relocation, the plan was thankfully jettisoned (Wright \& Mazel 2007: I40). Nevertheless, 3000 people on Ngwane reserve and freehold land were forced to move with the construction of Woodstock Dam (SPP I983: 293), built in I979, to increase water supplies to the industrial heartland of the country, the Witwatersrand. The KwaZulu homeland government, with jurisdiction over Ngwane territory, deposed and exiled the Ngwane chief, Tshanibeswe Hlongwane, who supported the resistance against the removals in which some people died. Not unlike Langalibalele of the Hlubi, who was granted permission to return to the Drakensberg as an old man shortly before he died, Tshanibeswe returned to his home in 2002 , only to die two years later.

When jurisdiction under the kwaZulu homeland government was suspended with the ending of apartheid, Ngwane and Zizi leaders and many of their followers began to distance themselves from Zulu nationalism, which had been consolidated within the Inkatha movement within KwaZulu-Natal in the I970s and 80s. In 2007, press reports recorded that the Ngwane, Zizi and the Hlubi were among a number of groups whose chiefs began to assert claims to independent kingship on a par with the Zulu king. The Ngwane leaders argued that their ancestors had departed from their home around the headwaters of the White Mfolozi River before Shaka had consolidated this area within the Zulu kingdom. The Zizi claimed never to have lived under the jurisdiction of the Zulu state (Daily News, II August 2005; Mail \& Guardian online, 8 July 2007; Mercury, 2, 6, and 7 July 2007 and Sunday Tribune I July 2007). 
An event that occurred in Ngwane territory in 1956 still haunts the imagination of people living there today. A group of armed men attacked police who were searching for marijuana in their fields around Ngoba. Five policemen were killed as a result. The apartheid state retaliated by arresting 23 men, 22 of whom were found guilty of murder and subsequently hanged at the notorious hanging jail in Pretoria (Wright \& Mazel, 2007: I40). Trading in marijuana has long continued as part of a lucrative 'shadow' economy within the region to this day. In his play, 'Bergville Stories', Duma ka Ndlovu, a contemporary playwright from Okhahlamba, re-evoked what had happened in 1956 . His explained the 'lack of development' in the region to be a consequence of what had happened in I956. In his view, the state had deliberately 'forgotten' the area ever since as a form of punishment (SABC 2006: 4).

\section{Some statistical dimensions}

Bearing in mind that the gathering of statistics in South Africa is not always accurate, the census data for I996 (seven years prior to the commencement of my own study) reinforced a picture of marginalization for Okhahlamba. With regard to employment, 63 per cent of people of working age were unemployed. This figure increased to 83 per cent in $200 \mathrm{I}$ (OM 2006: I8, SSA 200I), with only I7 per cent of the population in formal employment (ibid: I8). In the I996 census, most residents were described as unskilled or semi-skilled. The majority of households accrued collective earnings less than a minimum living level of RI 600 (\$228.57) per month, and 73 per cent of workers received incomes below the minimum living wage of R80o (\$II4.28) per month: figures that implied severe economic hardship.

Drawing on the same data, educational levels for the majority of the population were below Grade ıo, or two years below the completion of secondary schooling. Twenty seven per cent had no education, 4 per cent had matriculated, and tertiary education was negligible. The Okhahlamba Municipal Integrated Local Economic and Development Programme 2006-2010 (OM 2006: I6) showed very little difference with the I996 statistics in that 26 per cent of the population were said to have no education. In 200I, Isikhugusethu Environmental Services (IES 200I), having drawn up a development plan for the region, suggested that 56 per cent of the population over five years old was functionally illiterate and that their educational level was below Grade Six, the first year of secondary school (IES 200I). In 200I, the Okhahlamba municipality recorded that only 7.2 per cent of the population had passed the final year of secondary school and only I per cent had acquired a tertiary qualification in the form of a Bachelor's degree or diploma (OM 2006: I6).

In relation to the health status of the population, mortality and morbidity data for Okhahlamba from January to June 200I recorded that for 
adults, the greatest percentage of deaths was caused by preventable tuberculosis (33.7 per cent) and HIV and AIDS (12.8 per cent); and for children, by gastroenteritis (37.5 per cent) and respiratory disorders (4I.7 per cent) (data cited from IES 200I, section Health, point 2.72).

With the contemporary shrinkage of availability of unskilled work across the country as a whole, it comes as no surprise that people in Okhahlamba are increasingly dependent on welfare grants, including pension, disability and child support grants. Lack of employment has resulted in an escalation of crime, particularly in cattle theft and dependence on the cultivation of marijuana (Wright \& Mazel 2007: 139).

\section{Research context and method}

In March 2003, I was employed by the Centre for HIV and AIDS Networking (HIVAN) based at the University of KwaZulu-Natal to embark on a five-year research project in Okhahlamba, recording the experience of people living with and alongside HIV and AIDS, in which the first three years were spent doing fieldwork and the last two in writing up the research. I worked alongside two young women, Phumzile Ndlovu and Zanele Mchunu, who were employed by a local NGO that had worked in the region for over twenty years, and with whom HIVAN had established a partnership. The NGO was involved in a wide range of intervention activities and acted as a charitable conduit for donated goods from overseas constituencies.

My ethnographic project was to emerge from accompanying Phumzile and Zanele in their work in relation to home-based care initiatives, on the one hand, and 'orphans and vulnerable children', on the other. Phumzile and Zanele's knowledge of the area, companionship and friendship proved invaluable. With their influence, my spoken isiZulu began to revive. I had learnt the language in the I970s, during my time as a founding member of the Junction Avenue Theatre Company at the University of the Witwatersrand, where many of the songs of the plays we created were sung in isiZulu. In the I980s, working against the apartheid policy of forced removals and as a cultural activist within the Congress of South African Trade Unions (COSATU) in the Pietermaritzburg, it was imperative to speak isiZulu.

In working consistently with the two young women, and sometimes on my own, I came to know a wide range of people in Okhahlamba, including home based-carers, a number of people suffering from HIV and AIDS and their families, doctors at the local government hospital, HIV positive support-group members, children and young people who had lost one or both parents to the disease, a number of izangoma (diviners) and izinyanga (herbalists) who were concerned with widespread deaths in the region, and two poets. My research not only encompassed recording activities undertaken in NGO work, but also ongoing open- 
ended interviews with many of my interlocutors in isiZulu. In relation to children and young people involved in the study, I employed a set of theatre techniques in facilitating more open communication between ourselves. Continuing visits to individual homesteads and attendance at community meetings and ceremonies, including funerals and weddings, cleansing rituals around death and aspects of courtship more generally were carefully recorded in field notes that also provided a space for my own ongoing reflections. Recorded interviews conducted in isiZulu were transcribed and then translated into English in ways that aimed to retain some of the expressive qualities of the original Zulu. Details pertaining to groups with which I interacted and to the methods employed in undertaking the research are described in Appendix I at the end of the book.

\section{Chapter outline}

Each chapter within the book includes a theoretical theme linked to a detailed ethnographic account, revolving around the stories of individuals or groups. Names of most individuals have been changed to protect their identities, as have the names of some neighbourhoods, mountains and rivers. The names of the poets whose poetry appears in the book are real, in acknowledgement of the public nature of their work. As a consequence, I avoid any discussion of their personal lives.

To describe the shape of the book, I begin by focusing on the human body afflicted by the disease and work towards individuals' relationships within families; with myself, the outsider-ethnographer; with lovers; within neighbourhoods and with home-based carers.

In more detail, Chapter One explores the effects of HIV and AIDS on the human body linked to local notions of bodily integrity, as a reflection of the 'proper' physical and social body. Through a careful account of one young man's life and death, I link the falling away of bodily coherence, its vertiginous disintegration in undergoing AIDS, to fracturing social relations of intimacy within families where the ill reside. As Mary Douglas, Julia Kristeva and others have argued, those aspects of the body that threaten its coherence - the body's permeability and its fluids - are often linked with notions of pollution and deep-seated visceral response. The erosion of the individual's body in experiencing AIDS is thus inextricably intermingled with the idea of both bodily and social pollution and their attendant fears and prejudices. The chapter is thus an exploration of the ways in which care may be withheld in the face of a ravaging disease,

Chapter Two raises the question of ethics and the notion of ethical care in relation to undertaking research with people who are dying, or who are in mourning. It equally throws up ethical problems in relationships within families that resonate with the previous chapter. Ethnogra- 
phically, the chapter charts Phumzile's and my journey in friendship with a particular young man and his family over a five-year period. Theoretically, I draw on the philosophy of Emmanuel Levinas and Alphonso Lingus, whose work indicates the importance of pre-empting too quick an understanding of illness and suffering, and for allowing space for the ill to set the pace and the content of relationship. Levinas' insistence on solicitude and responsibility in the presence of the vulnerability of another is linked to the ways in which Phumzile and I, in addition to being of practical assistance to our friend, learnt through mutual interaction how to listen, how to remain silent, and how to respond when challenged. The chapter emphasizes the processual unfolding of ethics and care.

Chapter Three explores the ways in which 3I children and young people from a particular settlement in Okhahlamba, who had lost one or both parents through death, sought care and relationship within wider networks of kin and neighbourhood. The chapter revolves around notions of mobility and variation between the living circumstances of 'orphans'. I question the ways young people described as 'AIDS- orphans' have been uniformly and pathologically depicted in public discourse and a broad spectrum of media. Too narrow a focus on the vulnerabilities of young people who have lost parent/s through death obscures the ways in which they share similar circumstances with other poor children and youth, as well as the strengths they bring to bear on their circumstances and in fashioning care for themselves. The chapter therefore questions the way in which care has been framed in relation to orphans in development discourse. It gestures towards local repertoires of care and to social networks on which young people draw that 'refuse' their imagined social placement as orphans through the reach of global conceptions of vulnerability.

Chapter Four considers local parameters of care from the point of view of two healers, a nyanga (herbalist) and a sangoma (diviner), one of whom is HIV positive. They demonstrate the way the illness is folded into the overall dimensions of social life, including a sense of its apocalyptic disintegration, where illness cannot be understood outside shadows cast by histories that continue to haunt the present. The chapter encompasses the healers' personal wanderings beyond local environments and the ambivalence with which the wider world is viewed - an 'elsewhere' that nevertheless intersects with 'the local' through, among other things, migrancy. The healers' narratives provide particular examples of the construction of 'remoteness' and its appeal, a remoteness that has to do with the attempt to claim particular identities that are to a degree set apart from wider constituencies. The healers' stories show the multiplicity of healing frameworks that inform people's lives - the combination of both 'indigenous' and biomedical procedures and materia medica in the pursuit of health, and the construction of meaning that 
incorporates both exclusionary histories and aspects of Christian spirituality.

Chapter Five traces care between two lovers - both afflicted with the disease - who sought to marry, and who through time expanded their conceptions of self through 'holding' to relationship; through accommodating the illness as a third within it, as if it were a child; and through not abandoning one another. The chapter explores the interrelationship between sexual desire, the desire for procreation, intimacy and care. It draws attention to the ways in which care as social substance circulates through an exchange of sexual fluids in sexual relations that are blocked through the advent of HIV and AIDS and the necessity for 'safe sex'. The chapter therefore raises irresolvable problems around fertility and HIV and AIDS. It also explores ideal social expectations of care within the parameters of family, as symbolized in domestic objects exchanged through marriage. It throws into relief the rub of such expectations against the forms of care devised by the lovers in relation to supporting one another through illness. The chapter charts care in relation to its transformational possibilities, in that through not giving up on one another, the couple to some extent reshaped common masculinities and femininities in Okhahlamba within their own relationship.

Chapter Six is an overview of the extent of care of the ill undertaken by home-based carers in the neighbourhoods in which they lived, through a detailed account of one home-based carer's work, as I came to know it over time. The chapter explores horizons of local home-based care far in excess of any narrow definition. It shows how the care offered draws on both ideal notions of care within households and the procedural aspects of palliative care learnt in formal training courses and ongoing dialogue with a particular medical doctor from the local hospital. I explore the idea of home-based carers as brokers between different institutional domains, well placed to expand their patients' understandings of illness from a bio-medical point of view, but also to critique the oversights of hospital and clinic practice. In their interaction with people who are ill, what is particularly appreciated is their knowledge of bureaucratic systems and their sometime emotional sophistication in supporting them in ways that are respectful and that bear witness to their humanity. Philosophically, the chapter considers what it means for an ostensibly ablebodied person to accompany one whose capacities for endurance have worn thin through illness. Accompanying another entails the lending of bodily forces to an ill person in order to accomplish long and arduous journeys in the pursuit of health that would be impossible if contemplated alone. It is in such journeys, taken together, that mutual recognition emerges. Finally, the chapter traces the obdurate patience and endurance necessary on the part of ill people and their home-based carers in negotiating state assistance and institutional support. The chapter shows how everyday, ongoing care is predominantly in the hands of women and advocates on their behalf, arguing that the extent of their work 
be acknowledged, and that they receive some compensation from the state.

The Epilogue begins by drawing together threads of everyday life as described in the ethnography, that demonstrate the ways in which care is both given and withheld, or blocked. I pull together threads, showing how care and its opposite are found at many levels; the state, hospitals, nurses, home-based carers, family, the self. I suggest that the book has traced all of these, but not in a linear or mechanical fashion. Rather, it has described them as people navigate them in their everyday practices of meaning-making, health seeking, repairing, redressing, sundering, and for some, dying; for others, caring for the dying. I conclude by reiterating how people have used all their resources in confronting the illness, including poetic ways of speaking, imagining and navigating the everyday, such as, for example, the moral economies of 'gifting'. What has also become clear is that the state is absent or present so inconsistently that it can scarcely be relied upon. 



\section{The Vertiginous Body and Social Metamorphosis}

In 200I, Andries Botha, a South African artist, contributed a work to an exhibition on AIDS at the South African National Gallery. On close inspection, the piece, 'Rupture', proved to be a rendering of human skin. The curators of the exhibition, Kyle Kauffman and Marilyn Martin, wrote that it was a:

landscape of the body. There are bruises and veins that appear as stark and defoliated trees. The work ... emphasizes the bruised and battered skin of the body. It evokes notions of illness, abuse, decline and disintegration: a rupture. (Kauffman \& Martin, exhibition catalogue, 200I: 6-7)

Botha's depiction of skin in the publication in which it appears was accompanied by a written coda:

Skin represents the fragile physical membrane that mediates body, humanity, and identity. Its tenuous veil negotiates our relationships with the physical and emotional world. It also provides the necessary illusions of permanence, endurance and inviolability. (Ibid: IO-II) ${ }^{\mathrm{I}}$

The chapter marks both the sufferings of the flesh and the ways in which cultural understandings around HIV and AIDS in Okhahlamba at times increased the suffering of those dying of AIDS due to social isolation, and to the attachment of ideas of physical and moral pollution to those who were ill. Prior to the availability of antiretroviral treatment, notions of social and bodily coherence could not be upheld in a context of death on such a large scale. The literal and figurative dangers attached to the body's fluids were powerfully experienced in a context of AIDS, where transmission was precisely due to the permeability of bodies and the communication of fluids between sexual partners and between the ill and their caretakers.

Social worlds dictate which social categories of people may touch whom and in what ways. Spaces of intimacy in social life often begin with care of the body, through an older person tending to the bodily needs of an infant. The infant is cleansed, fed, and fondled, coming to know different parts of its own body through their being named and touched. The social relation between the older person and the child, their affinity, and to a degree their social interchangeability, is under- 
scored. ${ }^{2}$ Infants' helplessness is accepted, as people anticipate their growing independence. In the context of HIV and AIDS, the helplessness of a young adult or a child suffering from a multiplicity of afflictions that culminate in death is an inversion of the nurturing forms of care given to the young, in which the fullness of protracted adult lives is wished for.

In Okhahlamba, a plenitude of flesh beneath skin connoted health and beauty, as well as forceful occupation of the world. ${ }^{3}$ When the body's flesh eroded through the progression of AIDS, a person was left only with bones. 'Usala ngamathambo', 'You remain with bones', as the local saying went. The visible paring away of the body - its substance and efficacy in the world - was often mirrored by a paring away of benign social relations in relation to the person afflicted. At least the antagonistic substrata of many social relations of apparent intimacy began their stark and unforgiving emergence in the face of the disease's progression. Fear, although experienced in acutely intimate ways within specific family groupings, resonated on a broader social level. Public discourse was full of the muted yet powerful presence of AIDS, in that the virus with its attendant afflictions was often referred to indirectly as 'lesisifo' ('this illness'), one that could not be directly named. Not surprisingly, it was linked with shame, in that public reference to AIDS as a cause of death at funerals was rare.

In the ongoing ways in which AIDS rendered the body disorganized, the skin, the body's envelope, no longer smooth, erupted and became an angry, painful, perforated surface from which there was little respite. Multiple parts of the body were experienced as alien. When someone was particularly afflicted by their skin, people in Okhahlamba said that when they died, they had died of the skin, meaning the failure of the skin. Someone had died of the feet (izinyawo), referring to the swelling of the legs and feet; feet that could no longer endure shoes, legs that could no longer hold a person upright. Someone had died of the head (ikhanda), of protracted headaches associated with meningitis. Someone had died of the chest (isifuba), the lungs ravaged by tuberculosis or pneumonia. Lymph nodes swelled to obscene proportions in an armpit or a groin, the throbbing of such protuberances, an unendurable yet inescapable presence. A person had died of her stomach (isisu); she no longer had control over her bowels. Nothing that was eaten or drunk could be absorbed by the body, and everything flowed uncontrollably out of it. The mouth, through which a person spoke and ingested food, was coated in the white effulgence of thrush; gums bled. The entire body was rendered uninhabitable.

The vertiginous disintegration of the body, as manifested in a successive series of afflictions without a cure, drew fear. The failure of bodies to hold, to maintain a modicum of coherence was externalized and mirrored an experience of collapsing sociality. It was a sociality sometimes marked by mothers rejecting their returning sons - sons who had failed 
to maintain their rural homes and their ties with relatives through a distribution of their resources. Generally, the migrant was viewed with ambivalence, as being both a source of sustenance, but also one who could abandon a rural home. HIV and AIDS exacerbated family fears in relation to migrancy, as a son or daughter could return home to die ignominiously of an affliction that brought disrepute to the family concerned. The death of a breadwinner cut off the continuity of a homestead in tangible ways.

Michael Herzfeld (200I: 2I8, I992) writes of the social production of indifference - 'the production of callous disregard of large-scale suffering'. As Veena Das (1996 cited in Herzfeld 2001: 219) argues, anthropologists are challenged with the task of rendering suffering meaningful in a context where bureaucratic systems often justify exclusion of certain categories of people and therefore cannot recognize their suffering. She writes that lack of recognition 'stems in part from the fact that a society must, to some extent, hide from itself how much suffering is imposed on individuals as a price of belonging', and that 'the social sciences may be in danger of mimicking society's silence towards this suffering'.

John Caputo (I993: I58) suggests that 'Flesh is soft and vulnerable. It tears, bleeds, swells, bends, burns, starves, grows old, exhausted, numb, ulcerous'. Flesh is the soft perishable medium in which suffering occurs. 'What is suffering if not this vulnerability of the flesh, this unremitting unbecoming?' (ibid: 203). William Connolly (1999: 50), in reflecting on Caputo's work, seeks to bypass the abstractions of contemporary ethical theory by placing suffering at the centre of moral attention. He grounds ethics in the flesh, suggesting a concomitant obligation to respond to it, an obligation that is 'palpable, specific, situational and guttural'. He seeks to rescue ethics from the flattening effects of secularism, theology and philosophy (ibid: 48). As appealing as Caputo's approach may be, a critique of his ideas centres around the ways in which they position those who suffer as objects of obligation in relation to 'helpers' (ibid: 50). Connolly writes:

Some of the most difficult cases of suffering occur when people suffer from injuries imposed by institutional identities, principles, and cultural understandings, when those who suffer are not entirely helpless but are defined as threatening, contagious, or dangerous to the self assurance of hegemonic constituencies. (Ibid: 50-5I)

Drawing on the idea of the body's permeability, Steve Pile (I996: I84) has written of it as a site for the 'articulation of power, desire and disgust, of the individual, the social and the spatial'. Internal space, through the analytic framework of psychoanalysis, becomes interwoven with the external spatial and social geographies that individuals inhabit and produce. In relation to the above themes, I aim to show how internal and 
external geographies blur, in that the affliction of the body in relation to HIV and AIDS has powerful social resonance.

The story of Nkosinathi Dladla, as I came to know it, is related below as a way of bringing forward individual suffering, ${ }^{4}$ not only of the flesh but also in relation to fraught family relations attendant upon his affliction. Submerged within it are pointers to the way in which bodies undergoing AIDS were handled with unease and associated with pollution. As will be seen, these relate to the issue of using gloves to handle the young man, reluctance to clean his living quarters, a withdrawal of touch, and the general ambivalence with which he was viewed by some of his kin.

\section{The life and death of Nkosinathi Dladla}

\section{Nkosinathi's illness and treatment}

Like many young men in Okhahlamba, Nkosinathi left for Johannesburg, where he worked for several years. He set up house with a young woman from his home area. They were not married. One word used in isiZulu for the kind of informal relationship they had is kipitile. Its implication is that one forms a relationship without any strings attached. Nkosinathi became ill in 2000 , and after consulting doctors in Johannesburg received his first round of treatment for tuberculosis. He tested positive for HIV in 200I, yet kept his sero-positivity to himself on his return to his natal home in May 2003. His brother-in-law, a successful businessman in Johannesburg, brought him home when he was too ill to remain there. Although he returned to his mother's homestead with his girlfriend, she soon 'ran away', as family relations became more fraught. Phumzile was to learn through a conversation with a neighbour of the Dladla family that Nkosinathi's girlfriend had told her of her concerns while collecting water at a communal tap near the homestead. She intimated that Nkosinathi's mother refused to give them food, and instead used her money to bewitch them because she was angry that he had gone to Johannesburg without sending money back to his home. ${ }^{5}$ Nkosinathi witnessed his mother making umphako (food for the road) for one of his sisters who was returning to Johannesburg. While food was given to his sister, he remained hungry.

Zinhle Vilekazi, a home-based carer from a neighbouring community whose work is explored in detail in Chapter Six, had, on occasion, walked over a mountain to visit Nkosinathi at his mother's home. ${ }^{6}$ Many of Zinhle's terminally ill patients, those who appeared to have the bodily manifestations of full-blown AIDS, who had wasted bodies, and who suffered from diarrhoea and had lost all their strength, found a modicum of relief through being put on a drip at the local clinic. Zinhle asked Nkosinathi's mother whether the family could transport him there. As she expressed it, 'the water in Nkosinathi's body was finished'? She 
asked whether Nkosinathi's brother-in-law, the businessman working in Johannesburg, could transport him to the clinic, as ambulances in the region travelled between clinics and hospitals and not to individual homesteads. He agreed to do so, during a long weekend when he would be home. Zinhle also wanted to assist the family in obtaining a disability grant for the young man, and the family requested she accompany Nkosinathi on the visit to a clinic to register for the grant. I happened to be staying at Zinhle's home and we both attempted to meet up with Nkosinathi at the clinic in question. After having walked there, we found that the family had not arrived after all. A phone call established that, according to Nkosinathi's mother, he was reluctant to go to the local clinic because his girlfriend's relative worked there. He was afraid that she would inject him with the HI virus. ${ }^{8}$ Whether this was the mother's fear or what Nkosinathi had said to her, Phumzile and I did not know.

On the 27th of September 2003, the Monday following the long weekend, I offered, with the family's agreement, to take Nkosinathi to another clinic in a small neighbouring town. To Zinhle's and my surprise we found Nkosinathi's brother-in-law still in residence when we arrived to fetch him. Nkosinathi had been brought from his mother's homestead further up in the mountains the previous night, so as to easily facilitate our journey from his sister's home on the main road the next day. On entering the homestead, Nkosinathi's brother-in-law's silver BMW, which was being polished for his return to Johannesburg that afternoon, was most conspicuous. In conversation, Nkosinathi's brother-in-law insisted that he would like to send Nkosinathi to a good hospital, Grey's Hospital, for example, in Pietermaritzburg. The family appeared to have the resources to do so. Not only was the brother-in-law a successful businessman, his wife had a lucrative municipal post in the small regional town. Yet it seemed that despite what had been said, the family was reluctant to send Nkosinathi to a hospital that would incur further expenses.

When Nkosinathi emerged from a back room, emaciated and silent, he did not have a belt with which to secure his trousers, which were now too large for him. He walked extremely slowly, with one foot painfully following the other. He could not negotiate his way into the back of the truck where he thought he would be most comfortable, lying down. Rather, he sat next to me in the front passenger seat, after I had lifted his legs into the car. The two young people inside the house did not come out to wish him well. His brother-in-law exchanged a perfunctory wave at the door. As we were about to drive out of the driveway, his sister emerged from the house - she had remained hidden up to this point saying that she would accompany us. It was painful listening to the conversation between the sister and Zinhle in the back of the truck. The sister said that she hoped her brother would die soon, as there was no one to look after him during the day. She herself would have done so, she said, if she had not worked in town. Neither would her husband 
agree to his remaining in the homestead for a long period. It seemed that other family members were also reluctant to support him.

As soon as she saw Nkosinathi, the nursing sister in charge at the small town clinic threw her hands up in dismay and said, 'This man must go to hospital immediately'. She explained that she did not have a drip and suggested he go either to Emmaus, the local rural hospital, or Ladysmith Hospital. Nkosinathi whispered that he would go to the hospital his sister thought best. She decided to take him to the more distant hospital in Ladysmith. ${ }^{9}$ Fewer people would know Nkosinathi there. It was also generally thought that people received better treatment at this hospital.

After having dropped Nkosinathi at Ladysmith Hospital at Io.30 in the morning, I returned to Okhahlamba, taking it for granted that he would be admitted because of what the clinic sister had told me in the district town clinic. At 5.30 in the afternoon, Nkosinathi's sister telephoned to tell me that the doctor had seen her brother at 4.30, refusing to admit him. Nkosinathi's sister eventually found a lift back for them to Okhahlamba that evening, from relatives living in Ladysmith.

It had emerged in the doctor's interview at Ladysmith that Nkosinathi spoke of an HIV test he had taken in 200I, in which he had tested positive. Until the conversation with the doctor at Ladysmith Hospital, he had not told his relatives or the home-based carer of his status. After the abortive first visit to Ladysmith Hospital, Nkosinathi later returned there. A doctor gave him medication that seemed to improve his state of being, in that he began to eat again.

\section{Nkosinathi's death and funeral}

On the I6th of November 2003, Phumzile and I were informed that Nkosinathi had died three days previously. The next day we attended Nkosinathi's isililo, an all-night gathering of mourners where women related to the deceased receive people wishing to speak about the dead. (Isililo literally means 'lamentation'. See Dent \& Nyembezi I969: 404.)

Arriving at the Dladla homestead at 6.30 in the evening, we took off our shoes on the threshold of the house and entered, sitting on the righthand-side, close to the door. The women of the family were seated opposite us on the left-hand-side and at the back of the room, facing the entrance. There were traces of impepho (helichrysum Miconiaefolium, a cleansing herb associated with clarity and ancestral shades) that had been burnt next to a candle. ${ }^{\text {Io }}$

The five women sitting opposite myself and Phumzile belonged to Nkosinathi's mother's family. One was his mother; another, his mamncane (younger mother referring to his mother's younger sister); another, his malumekazi (mother's brother's wife). Closest to the door was his younger sister, Sibongile. The older women sitting against the wall, facing the door, were Nkosinathi's paternal aunts. The aunt who intro- 
duced the family members to visitors opened the discussion by saying: 'We have lost, we of the Dladlas!' ('Silahlekelwe thina bakwa Dladla!')

The conversation began innocuously enough. A senior paternal aunt spoke of how Nkosinathi had worked in Johannesburg for three years, 'supporting his mother with groceries', although Phumzile and I knew that this had not in fact been the case. She continued: older people sent their children to schools because they had never had the opportunity to learn themselves. The young could count, whereas older people could not count accurately. When children die there is great sadness. Oh! There is death (kuyafiwa). Her words suggested how the world is inverted when the young die.

It transpired that Nkosinathi's younger sister, Sibongile, became important in the care of her brother before his death. Although she was a married woman and lived in her own homestead, she regularly brought him fruit and vegetables; she cooked for him, fed him and spoke with him. Zinhle, the home-based carer, had also spent hours speaking with Nkosinathi, cleaning him, feeding him and speaking of various ways of coming to terms with death, including its transcendence through religious faith, she being a staunch Christian.

Sibongile's thoughts about her brother, as she expressed them during the isililo, revealed some of the underlying tensions within the family in relation to Nkosinathi's decline. Her words underscored her tender involvement with her brother and his particular isolation whilst dying.

Sibongile spoke of how Nkosinathi had gone to work in Johannesburg three years prior to his death. She felt his absence because during that time, he had not communicated with his family in Okhahlamba. On his return in May 2003, he stayed in his mother's house. At the end of each month Sibongile bought airtime for Nkosinathi's cellular telephone so that he could telephone her, which he often did, telling her that he was hungry. She would bring food, sit with him and feed him. She would shout at the people in her mother's homestead, asking them why they had not made him food. They would reply that he had been telling lies about not being fed. One day, when Sibongile visited her brother, he asked her to hold him. He had said, 'Come and hold me. Hold my hands'. She could see that he was very ill. She held him in her arms. She did not know what he felt when she held him, yet she knew he wanted to be touched.

Another morning, Sibongile was inclined to spend a long time with her brother. She lingered with him and he told her to go to work. 'You have to go to work', he said. 'Who will buy me food if you do not?' Remembering this intimate detail, Sibongile felt the loss of her brother acutely and exclaimed, 'Oh, he is gone! What is there to say?' Sibongile then continued telling us that Nkosinathi had walked a short distance the week before his death to his grandmother's house. She thought he was recovering. He could now make food for himself when he was hungry. 
Sibongile thought of Nkosinathi's educational achievements the morning of the isilito. He had always been bright at school. She had looked at his matriculation certificate. He obtained B aggregates in mathematics. When her own child had problems with mathematics, she would tell him to visit his uncle. In the morning, Sibongile sat handling and reading his diploma in accounting and bookkeeping, as well as his driver's licence. While Sibongile held and read her brother's certificates, she longed for his skills to be transferred to her so that they would not be lost. His death seemed a cruel ending to what he had acquired. He had received more training than any other member of the family. In the end, Sibongile concluded that Nkosinathi's gifts belonged specifically to her brother, and that no matter how she desired their transferral to herself, as a means of perpetuating his presence in some way, this could not be done.

On the Friday when Nkosinathi died, Sibongile, his mother, and his mother's sister were present. He could no longer speak. His legs were cold and his head hot. Sibongile prayed for him together with her family. When they stopped praying, they saw that his spirit had gone. Nkosinathi's mouth was open. It was as if he had wanted to say something. He had died whilst they were carried away in prayer because 'God [did] not like people to see how he [took] a person back to himself'. When Nkosinathi's mother saw that her son had died, she fell to the floor. This seemed to suggest to Sibongile that in spite of her mother's rejection of her brother during the time of his illness, she had loved him. She had not fallen to the floor when her husband had died, Sibongile noted.

I attended Nkosinathi's funeral on the following Saturday. Despite the incipient conflicts in his family, Nkosinathi's funeral integrated him back within his family and the community. The Priest and choir of the Dladla family's own church were busy conducting another funeral, so a priest from another denomination agreed to perform the service. Many important dignitaries came, as the Dladlas were a prominent family. Nkosinathi's girlfriend did not attend; neither had she visited the family to commiserate about his death. Rather, Nkosinathi's ten-year-old daughter who lived in Durban - a child from a previous relationship - was present. Eight young men with whom Nkosinathi had worked and lived in Johannesburg drove down to the Dladla homestead at three o'clock that morning. They sang and danced on top of his coffin, stamping layers of soil onto the grave several times before anchoring it down with a circumference of heavy iron-stone and a blanket of fresh grass. They informed me during the funeral feast that they came from all over Zululand and would return to Johannesburg immediately after eating and washing themselves. Whatever the conflicts within Nkosinathi's family prior to his death, many people attended his funeral and it was carried out in a way deemed fitting. His grave formed the newest in a line of five, including that of his father. Given appropriate family rituals, he 
would in time join the abaphansi (those from below), the ancestors, where he would continue to play a role in the affairs of the living.

On the Ioth of February 2004, I met Sibongile once more. She was suffering the loss of her brother greatly and had no one with whom to speak of her anger in relation to the fracturing of family relationships attendant upon his illness and death. She insisted that, although she was the only family member who cared for her brother before his death, family members were now fighting over his possessions. Her mother had recently called her to a dispute over one of his television sets. Sibongile refused to go, saying that having her brother's possessions was not important to her. In any case, in her opinion, Nkosinathi's daughter was the person who should be entitled to anything that he had bought while working in Johannesburg. He had been a good worker. He always bought items in pairs. This was his particular style: two television sets, two wardrobes, two cell phones, and two beds. It was hateful to her that relatives who avoided him because they knew he was HIV positive were now fighting over his possessions. Before he died, Nkosinathi told Sibongile that he wanted to give her his special pens. She looked around the room for them but could not find them. Her brother remarked sadly that their disappearance showed that the family was already taking things that belonged to him before his death. His desire to give his pens to his sister while he was still alive marked his acknowledgement of her care for him at the time of his greatest affliction. It was also a way of openly sharing with her that he knew he was to die.

\section{The significance of touch}

Reflecting on Nkosinathi's story, it is important to acknowledge the complexities of touch in the context of AIDS. Touch is an embodied way of insisting on an intimate, shared, social world. It is precisely at the places of intimacy that the social is simultaneously upheld and begins to unravel. It is through the skin that we are also able to touch the world. The surface of the body receives textures, the varied degrees of heat of animals and objects. Non-violent touch is that subtle interchange where the hand bears witness to the life of others, both animal and human, or the presence of objects and the particularities of their density, weight and contour. Non-violent touch that lies alongside that which it touches, allows for mutual exploration and surrender. ${ }^{\text {II }}$

Through his visit to Ladysmith Hospital and through the presence of his oldest sister, Nkosinathi inadvertently acknowledged to his family his HIV positive status. Such a status, although not publicly declared, was tacitly pointed to in many ways. These included the withdrawal of food by his mother's household, the antagonism directed towards him by his mother, an almost blanket withdrawal of care on the part of most members of his family, and a reluctance to clean his quarters. Later, his younger sister could speak openly to him about his condition. She told 
Nkosinathi that he should not be unhappy at her request to use gloves to wash him. It was not that she did not love him or that she found him offensive; wearing gloves was to protect herself from the virus. The word Sibongile used in isiZulu to refer to the fact that she did not find him offensive is a powerful one, ukunyanya. Ukunyanya connotes disgust or loathing and suggests uncontrollable and visceral responses to areas of life. Nkosinathi's response to Sibongile delicately negotiating the use of gloves to bathe him was that he had been relieved of a great burden. He had been conscious of his own potential to 'infect' her.

To return to the story of Nkosinathi, his plea for a sister's touch, a particular sister who continued her loving relationship with him in spite of the extreme changes in his body and the social, moral and physical pollutions attributed to his illness, underscored the way in which his experience traced the increasing discomfort of bodily disintegration, and a concomitant isolation, not only due to bodily processes, but to frightening social exclusions. The plea to be touched was an attempt to insist on a particular kind of sociality and love, an affinity that implied a trafficking across what Susan Sontag (2002: 3) has named 'the kingdom of the well' and 'the kingdom of the ill', the kingdoms to which we all have dual citizenship, making them both part of a claim to humanity. It was a plea for recognition that he was still the same person despite the ravages inflicted by his illness.

Touch in relation to care is important in soothing the sick. When women expressed its importance to me, they in most cases repeated a similar physical movement with their arms. They created a sense in which their arms were able to surround a person who was not feeling well, 'to make him happy'. The embrace suggested a containment of the affliction, a re-appropriation of a person into a shared world out of the isolation of being ill.

In the conception of an ideal local world, that is, one without fear, touch in relation to care and to erotic life was ideally of the sensuous kind where skin touched skin, where one could 'taste properly' the life and warmth of another. This was directly expressed, for example, in rejection of condoms, as in sexual intercourse, the sensation of 'skin to skin' was deemed important.

At a church service to which I had been invited by Zinhle Vilekazi, Nkosinathi's home-based carer, the mutual washing of feet between herself and her HIV-positive patient, and in my own with a friend who was HIV-positive (also the home-based carer's patient) became significant. It was an equalizing gesture mirroring the biblical story of Christ washing the feet of his disciples, a mystery deepened by the idea of a god's humility, and his taking on the flesh of mortality. In the ritual of the washing of feet, the distinctions between each pair seemed to dissolve, between the person who was ostensibly well and one who was not. In the gesture of mutual touching, respect and cleansing, the line dividing two people collapsed into coevalness. The one who was now ill had once been well, 
and the one who was ostensibly well would come, at some point, to a place of being ill. It seemed that this gesture allowed a place for compassion to emerge, as well as mutual recognition that went beyond the distinction between so-called 'health' and 'illness'.

\section{Symbolic investments in the body}

\section{Pollution and the abject}

I begin a more theoretical exploration of the idea that fear, silence and stigma in some respects have to do with the body's metamorphosis in undergoing full-blown AIDS. Ethnographically, my claims are based on what Veena Das and Pamela Reynolds (2003: 6-7) have called the importance of contingent moments in anthropological research; moments that unfold in time without the researcher's probing, moments that emerge because of long-term immersion in a research context. For ethical reasons I found it inappropriate to interrogate Nkosinathi's experience of his own bodily demise. The ways in which ideas of pollution were submerged in his story have already been mentioned. Information in relation to fear attached to bodily fluids resulting in stigma was gathered obliquely across many social contexts in the region. One setting included the hospital where I, together with a group of home-based carers, observed nurses deliberately ignoring patients who wanted to relieve themselves. In reflecting on their time spent in the hospital assisting patients, home-based carers recounted stories in which nurses were astonished by their quick response in cleaning AIDS patients who had become incontinent, and in which nurses told them of the 'necessity' of wearing three pairs of gloves in handling patients in order to protect themselves. On numerous occasions in large meetings, smaller support group meetings and in individual meetings with Phumzile and myself, home-based carers shared stories in which families left the ill to lie in their own bodily fluids, and where the carers redeemed patients' humanity in the act of cleaning their bodies and teaching family members how to do so. The ways in which patients were strongly associated with pollution were born out in stories in which food and utensils were handled in relation to the ill. In rare and private moments with individuals who were afflicted with the virus, they disclosed to me their own alienation from their disintegrating bodies. For example, Mandla Shabalala, whose story appears in the next chapter, discussed with me the way in which the skin peeled off his body daily; how in this highly visible condition he refused to journey outside his homestead, not even to access medication, because of the shame attached to his body, in that it was so easily 'read' by others. It was a shame mirrored in his girlfriend's increasing reluctance to clean his blankets. Here an individual expressed horror at his own condition and came face-to-face with the abject in himself. It is on the basis of such 
multiple contingent moments that I explore theoretically the idea of abjection. In the places of intimacy, of care, where the illusion of the body's boundaries was palpably exposed, fluids attached to the body were understood as contaminating. The uncontrollable voiding of faecal matter, for example, came to stand for a prefiguring of death and the ways in which death could be passed from one to another. ${ }^{12}$

Drawing on anthropological and contemporary philosophical literature, theoretical strands linked to the body as a symbol of coherence, as well as the eruption of the abject into the space of coherence, are unravelled in the following three sections of the chapter. Although the disintegration of the bodies of individuals afflicted with AIDS aroused fear, irrespective of gender, an examination of how particular fluids were viewed more negatively than others, and indeed tended to attach to gender, is important in pointing to the ways in which blame for the virus was often differentially allocated. A differential allocation of blame also points to the way in which the virus precipitated unease, not only amongst broad groupings of kin, but also within intimate sexual relationships. Fluids regarded as polluting were linked to gender in specific ways that rendered invisible male culpability in the face of the affliction. The ways in which negatively viewed fluids attached to gender is explored through the utilization of some ethnographic literature, as well as ethnographic data collected in Okhahlamba concerning women's use of a jelly-like substance in controlling the sexuality of their male partners. Although data from Okhahlamba pertaining to ancestral involvement in conception and the qualities of semen does not appear in the chapter, conversations with a number of traditional healers in the region have brought up philosophical ideas in relation to conception similar to those expressed by the ethnographers Alex-Ivor Bergland (1976) and Harriet Ngubane (1977), to which I refer.

Returning to the discussion of the abject, in relation to the obduracy with which particular body parts are imbued with specific meanings, in her volume, Volatile Bodies: Towards a Corporeal Feminism, Elizabeth Grosz (1994) writes:

The investments and significances attributed to the different regions of the body image are not simply the consequence of the subject's sensations or the subject's relation to others but also result from the significance of body parts for others (their own as well as the subject's). In this sense they are never self determined, voluntarily adopted, or easily shaken off, for they are to a large extent a function of socially shared significances. (Ibid: 79)

It is a well-established anthropological idea that the human body provides a rich source of symbolism in relation to social and political relations. ${ }^{\mathrm{I}}$ In many cultural contexts, the ways in which the body's coherence is constructed reflects notions to do with social cohesion and propriety. When the body itself implodes, when subjects no longer have 
control over their eliminatory functions, or control over the ways in which substances are ingested and digested by the body, and where groups of people come to witness widespread deaths, as in the case of full-blown AIDS, it is to be expected that the body's disorganization may come to exist alongside talk of dis-ease within social worlds. The response of onlookers to the disintegration of the body in those who are afflicted also calls forth emotions and actions that are not happily admitted in ideal imaginaries of social life. It is within the network of sometimes unpleasant processes that many individuals who are ill come to a place of increasing isolation. The poet John Donne expresses the nature of such isolation in relation to his own struggle with illness in ways that resonate with Nkosinathi's story, as it has been explored above. He writes:

As sicknes is the greatest misery, so the greatest misery of sicknes is solitude; when the infectiousness of the disease deters them who should assist, from coming; even the Phisician dares scarce come ... it is an Outlawry, an Excommunication upon the patient. ( 1627 , from Devotions upon Emergent Occasions referred to by Susan Sontag 2002: I20)

It is the irruption of the abject, and the experience of the afflicted in being relegated to a place of abjection, that in some respects marks the ways in which hegemonic society skirts around the suffering of individuals. $^{\text {I4 }}$

As Mary Douglas has argued, substances that constitute the abject, or the unclean, do not constitute dirt in themselves (Douglas I980: 5I). Rather, the abject is 'what of the body falls away from it while remaining irreducible to the subject/object and inside/outside oppositions' (Grosz I994: I92). Dirt is therefore that which 'upsets or befuddles' order (ibid). AIDS creates disorder in the bodies of the afflicted, as well as in social worlds, due to large-scale deaths. This was particularly the case, for example, with regard to Nkosinathi, when access to antiretroviral drugs seemed the prerogative of the privileged - those with access to money, resources, and easily accessible services. All of these seemed to be realistically unobtainable from the point of view of many people living in rural communities at the time, or from the point of view of people who returned to rural homes from the cities to die.

\section{The indeterminancy of fluids}

In an appropriation and expansion of Douglas's ideas, the general theme of Julia Kristeva's Powers of Horror: An Essay on Abjection (I982) has to do with the qualities of fluids in relation to ontologies that have tended towards solidity. ${ }^{\text {I5 }}$ Non-fixed parts of the body, including its fluids (blood, tears, urine, semen, menstrual blood, saliva, faeces, vomit and pus), retain something of the value of the body even when they are separated 
from it. Grosz (I994: 79) has written how they remain 'magically linked' to the body image. Body fluids suggest the body's permeability and its dependence on an outside. There is always the possibility of collapsing into the outside, as in death. The divisions between the body's inside and its outside are therefore not inviolable, and carry with them the ideas so well expressed by Douglas to do with pollution, matter out of place, and the consequent necessity of their control and containment through bodily comportment and practice. As Douglas argues, the fluid connotes a borderline state. Despite all precautions in relation to trying to establish the clean and proper body, fluids trace the paths of entry or exist from the body and mark the routes of interchange or traffic with the world (Grosz I994: I95). 'What is disturbing about the fluid is its refusal to conform to the laws governing the clean and proper, the solid and the self-identical, its otherness to the notion of an entity' (ibid).

\section{Body fluids and gender}

Sexuality - that area of life so visible in the public sphere yet hedged around with secrecy, shame, explosive violence and unconscious relations of power in the spaces of intimacy - is coupled with danger, danger unto death. ${ }^{16}$ Although erotic life has always been associated with the relinquishing or transgression of boundaries, with a kind of death, as well as with the transformation of pain into pleasure (de Sade I990, I988, I987; Bataille I998, I997, I991, I988; Foucault 1978), in the face of multiple actual deaths, the world becomes a dystopia in which libidinal freedoms are irrevocably sinister. In Okhahlamba, the ideal homestead strove for solidity, bridging the urban-rural divide. A wife was expected to anchor the rural homestead through her presence and to await the arrival of her husband. Yet these attempts were challenged in painful ways. It is as if the illusions with which peripatetic migrants battened down their rural homes as places of solidity and genealogical coherence, as places of origin to which one returns, began to unravel when 'sexuality unto death' threw up gendered fault-lines. ${ }^{17}$ It is as if these fault-lines were too threatening to acknowledge, as with their acknowledgement a whole restructuring of society would be inevitable. They were fault-lines that brought sexuality under scrutiny. Yet too close a scrutiny of male sexuality was, and is, something that is fiercely resisted in patriarchal worlds. Thus the reasons for the epidemic were deflected into a multiplicity of existing explanatory frameworks to do with witchcraft, the signifying of women as carriers of pollution, and the projection of blame onto an erstwhile category of oppressors. ${ }^{18}$ While this was what was stated publicly, in the painful trajectory of individual illness and the shrinking sociality that many of the afflicted came to endure, there was often a painful self-questioning as to where blame should lie. For example, a husband may have come to feel the pain of knowing that he was responsible for infecting his wife because he had been too afraid to declare his 
status openly and had consequently continued having unsafe sex with her. $^{\text {I9 }}$

Douglas' conceptions of purity and danger are linked to the relation between what we hegemonically describe as the two sexes. She views pollutants in relation to social order as analogies. In some contexts, each sex is a danger to the other through contact with sexual fluids. In other symbolic systems, only one sex is endangered by contact with the other. In most cases, females are dangerous to males. Douglas' point is that the two sexes 'serve as a model for cooperation and distinctiveness of social units’ (Douglas I980: 3).

In local conceptions held by many people in Okhahlamba, the ancestral shades of both men and women are present during sexual intercourse. The shades of the woman bring the woman's blood to the place of conception. The shades of the man bring semen, which is referred to as water with all its positive, purifying and life-giving attributes. ${ }^{20}$ Semen is seen to be the active agent, moulding the child out of the blood brought by the woman's shades (see also Berglund i976: II7f). Through her blood, the women's shades give 'food' to the growing infant. The male shades build the strength of child, and the mother will say to the father when the child is kicking strongly in the womb that he has strong shades. In fieldwork undertaken in the Nyuswa and Ximba areas of KwaZulu-Natal, Harriet Ngubane (I977: 94-95) pointed to the use of metaphors likening women to soil and men to the sowers of seed or the quickening sun. These ideas are similar to 'western' notions to do with gendered bodies and their fluids, where semen is 'the precious stuff' circulating in sexual relations. It is therefore not 'the movement of desire, the exchange of pleasures, but the transmission of seminal fluid, oozing through the male body into its resting place, the female body' that is deemed important (Grosz I994: I96).

Aristotle's (I979) view on the operation of semen is likewise similar to local conceptions among some Zulu speakers as outlined above. For Aristotle, semen not only provides form for the developing foetus, but also for the formlessness of menstrual fluid itself. He writes that semen acts upon menstrual blood as rennet upon milk, setting menstrual fluid into a form (On the Generation of Animals, Book II.IV).

Like local models, 'western' models that deal with the movement of bodily fluids do not consider the polluting contamination of sexual bodies as a two-way process. The acknowledgement of contamination as a two-way process demands a sexual symmetry that is missing in patriarchal structures. In most literature about male seminal fluid, it is 'understood primarily as what it makes, what it achieves, a causal agent and thus a thing, a solid: its fluidity, its potential seepage, the element in it that is uncontrollable, its spread, its formlessness, is perpetually displaced in discourse onto its properties, its capacity to fertilize, to father, to produce an object (Grosz I994: 199). ${ }^{\text {2I }}$ 
In Okhahlamba, fears around HIV and AIDS and control of one's men folk gave rise to stories about the ingestion of a substance called inoni, reputed to be a jelly-like material from the sea that women drank in the form of a tea to keep their sexual partner/s from straying. ${ }^{22}$ In line with fears to do with fluids and the viscous, inoni was said to expand when placed in a bucket - there was no limit to the expansive potential of the substance. Inoni, when given to a man in food or drink, kept him faithful to the woman who gave it to him, and even an ugly woman would become beautiful in his eyes. The ingestion of inoni by a man could, however, lead to his death, or so one old woman argued during a taxi journey. She blamed her son's death on bewitchment from his girlfriend whom she called a prostitute for using inoni to keep her son bound to her. She could tell that the substance had killed her son because he died of a distended abdomen. This was due to the propensity of inoni to expand in the body of a man once he had ingested it. Although many women viewed inoni as innocuous, in that its chief attribute was the promotion of beauty in the woman, it was said to result in the production of worms issuing from women's vaginas, something viewed with abhorrence. ${ }^{23}$ It was through such talk, in this instance about inoni, that sexual diseases, which came to lodge in women through heterosexual intercourse, were blamed on them. In public discourse, some men were also quick to blame women for AIDS, the reason being that women used contraceptives that were said to be antithetical to 'natural' sexual relations. It was only when talking privately and confidentially that women expressed fears that husbands may have brought the illness to them, as they claimed powerlessness in relation to husbands and lovers in negotiating condom usage. Women were expected to be the 'grinding stones' of their homesteads, their keepers, while their husbands were away. Using condoms with wives was said to promote their promiscuity. Although men might use condoms with their girlfriends, they were reluctant to do so with their wives, as they constituted the anchor of homes within a wider context of fluidity - at least, that is what men hoped.

\section{Conclusion}

I have explored the relation between the demise of bodies afflicted with AIDS in relation to the social dislocation of AIDS sufferers. In so doing, I point to new areas of research concerning the blurring of biological and social boundaries. Spatial considerations do not only refer to external geographies acting as a ground for social life, but also show that the body and its internal landscapes are affected by, and in turn influence, the everyday textures of the social.

By way of drawing the chapter to a close, I return to the story of Nkosinathi. When Phumzile and I were about to leave his isililo, his older sister and her husband arrived, asking whether we would like to see a 
photograph of her brother before he was ill, when he was 'strong'. We reentered the house and gazed at the large, framed image of Nkosinathi in his prime. It was a formal portrait of his face and torso. He looked out of the picture frame with assurance, with the confidence of a handsome young man. He sat weighted by a flesh-filled body, a fuller face. The image suggested a presence anchored in physical plenitude. The young man we had known occupied the world predominantly in silence, his elongated frame shaking with every effort to move, in which every gesture took on enlarged proportions due to the slowness with which it was executed. In bringing his image to the isililo, the family wished to recall Nkosinathi as he was before his illness, to hold up an image of apparent solidity against the horror of his decline. In looking at Nkosinathi's photograph, I began to weep, my body wracked with sobbing. My tears had to do with the untenable juxtaposition of the photograph and the man I had come to know.

In what has been written above, there is the constant presence of a 'doubleness', the idea of a fight for coherence held up against disintegration. Body maps created by women with HIV and AIDS in Cape Town visibly reproduce this doubleness. Each image contains a solid background figure superimposed by another bodily outline, in which the virus is invariably depicted as a series of piercing holes (see Morgan et al 2003: $16,36,62$ ). The paring away of fleshly existence over the course of full-blown AIDS is hard to bear and, as has been argued, its effects, already social, resonate outwards into intersubjective relations beyond the parameters of the body. 



\section{Mortality and the Ethics of Ethnographic Research}

\section{In the presence of death}

I wish to sketch briefly the reception of individual deaths in the neighbourhoods in which I came to know people, to create an awareness of the effects of the multiplication of deaths within the society of the living; the ways in which death casts shadows amongst those who survive; the ways in which a preponderance of death is deeply disturbing to people's sense of the world and its proper construction. In the previous chapter, I dealt with how the particular forms of death attendant upon AIDS - preceded as they are by protracted, corporeal suffering, and attached to notions of shame - may realign social relationships. Here, I relate Phumzile's and my ongoing interaction with another young man, Mandla Shabalala, and his family. Through remaining close to our unfolding relationships, I seek to delineate the ways in which questions of ethics, in relation to research and in the face of a particular person's suffering, emerged through time, in careful mutual creation of co-presence. An ethical thread to our interaction could not be presupposed through an appeal to a pre-given set of rules. Instead, it emerged within sensitivities, including the capacity on our part to suspend a particular approach and to reconfigure how to listen to pain and silence at different moments. In short, through our interaction with Mandla, we learned how to accompany a particular person in his suffering. We developed an ethic of suspending too quick an understanding, of holding off the impulse to intervene, or to fill silence with speech, to allow an ill person time in which to engage in ways that they had chosen.

The research, commingling with a certain intimacy, as is the nature of ethnographic work, was increasingly conducted with a weighty sense of the presence and possibility of death. Phumzile and I frequently attended and heard of funerals. In September 2003, Zinhle, the homebased carer of the young man whose story appeared in the previous chapter, compiled a map with me of 68 homesteads out of the hundred in her neighbourhood. We placed a red dot next to 22 out of the 68 homes in which no deaths had occurred from November 1999 to the day on which we drew the map in September 2003. From November I999 to September 2003, a total of I07 people had died in the remaining 46 homesteads. They were mostly between sixteen and 57 years old. In 
43 homesteads, one to three people had died, in one seven and in two homesteads, six each. Subsequent to making the map, I came to know of ten AIDS-related deaths in the same community, including one of a dear friend who, although she had survived HIV and AIDS, was killed in a car accident. Although not all of the above deaths can be unequivocally attributed to AIDS, many of them can, as the HIV status of patients was in most cases known by Zinhle. She identified three non-HIV-related deaths: one she attributed to old age, another to murder, and the third to suicide. While we made the map, she recalled stories of each person who had died. There were a number of widows in the community, many of whom were HIV-positive, who shared their HIV test results with her, and subsequently with Phumzile and myself. (Fieldnotes, September 2003)

The way multiple deaths haunted the living and everyday life was marked visibly in one of the widow's homes. She lived alone in a wellappointed 'modern' house roofed with red tiles. Her two daughters and a son had contributed earnings towards the building of her home. The woman's children, together with her son's spouse and child, had died. In addition, two of her brothers who had lived in the same homestead had also died. Altogether, seven kin and household residents had died. In anger, the woman asked me how it was possible that a house built by her children, a house that marked their effort and success, was now empty, not only of people, but of meaning. The beauty of the house, its deceptive solidity, constituted a bitter mockery in the wake of their deaths. Her home, although bearing the marks of care, a startling newness, was in reality a sepulchre.

In learning through two telephone calls that both an adult son and an adult daughter had died on the same day in two different hospitals, a mother collapsed onto the floor of her home, rolling from side to side in her grief. Zinhle was present in the homestead when the mother received news of the death of her second child. (Fieldnotes, September 2003)

In May 2005, another home-based carer arrived at our office in the small district town of Bergville to ask our advice (fieldnotes, II May 2005). A woman accompanied her, frozen in her grief, her body rigid, her speech jagged. Her son had been buried that morning. After his funeral she had learnt that her young daughter had died the same day in hospital.

A grandfather, whom I met in the neighbourhood of Amatikwe where I met frequently with 3I children and young people who had lost one or both parents through death, told me that his five grandchildren who lived with him had come to replace five out of six of his own children who had died. One of his sons had died at his place of work from a drowning accident. Four other children, including the mother of a brother and sister with whom I interacted on a regular basis, had died of lesisifo ('this illness'). ${ }^{\text {I }}$ The old grandfather had one remaining son living in 
the homestead with his young bride (umakoti) (interview, 20 October 2003).

In February 2005, Phumzile and I came to know Rain, a little girl aged four years who was HIV-positive. In 2004, her mother, an adolescent, died of an AIDS-related illness. Her mother's mother and her grandfather had also passed away from the effects of the same disease. Rain lived in her maternal great grandmother's homestead. She was so ill that she required anti-retroviral treatment. Her great-grandmother and her mother's brother's wife did not want her to take anti-retroviral syrups, as they held store by amakhambi esintu (indigenous herbal medicines). The complexity of administering precise and differing measurements of antiretroviral syrups to children seemed to defeat Rain's great-grandmother. A home-based carer offered to house Rain in her own homestead, where the syrups could be administered in the correct quantities and at the prescribed times. Rain's great-grandmother did not want to part with the little girl because she described her as being the belt with which she comforted herself ('Uyibhande lami engiziduduza ngalo'). The metaphor described their relationship as one in which the girl's presence bound and held her stomach, a place in which the great-grandmother felt grief had palpably come to lodge itself. The metaphor implied that she sought to shore up and to hold to herself layer upon layer of grief. (Fieldnotes, May 2005)

In September 2005, I attended the funeral of an HIV-positive woman I had known for two years. There, a grandmother described to me the scale of deaths she had experienced, saying, 'My child, we are being attacked from the four directions'. Pointing to each direction, she said, 'We are being attacked by death from other there, from down below and from both sides' ('Sihlaselwe ukufa ngenhla nangezansi nasemaceleni').

Throughout my stay in Okhahlamba, people in many parts of the region increasingly remarked on the number of deaths in their homesteads and neighbourhoods, and noted that they were called upon to attend more funerals than other community gatherings. Grandmothers and grandfathers, who bore the brunt of a younger generation's deaths in that they shared the responsibility of caring for those who remained, often asked the question, 'Who will bury me when I die?' Old women recognized the scale of mourning, as they moved from homestead to homestead, sleeping in the homesteads of the bereaved to offer comfort prior to a burial, sometimes for ten days at a stretch and for a few days afterwards. Older female relatives, as well as neighbours, were required to support the bereaved in this way. If neighbours did not appear to support homesteads in which a person had died, they were sometimes accused of having an interest in the death and hence of bewitchment.

There was a sense that the forward-looking nature of everyday life was being reversed. The young were dying before the old. What then of the continuity of generations, the penultimate consolation in the face of 'normal' deaths? Death was compounded by the general fear surround- 
ing AIDS; the sorrow that AIDS was issued into being in the most intimate spaces of social life, in the very place where human life was created. All were aware of the fearful attrition in the bodies of those afflicted, and were conscious of the social wounds accompanying the affliction.

Mam' Dladla (interview, I6 June 2004), the mother of an HIV-positive home-based carer, Ntombikhayise, whose story of love is related in Chapter Five, remarked on the layering of deaths in her own extended family in a particularly vivid manner. She was an isangoma esinabalozi, a diviner of the highest order. Here the voice of the ancestral shade who is said to possess the diviner is heard issuing from different parts of the dwelling in which a consultation is taking place. ${ }^{2}$ Ancestral shades make their presence known to diviners through the air, as is the case with abalozi, through sneezing, and through dreams. In 2002, Mam' Dladla's eldest son died of AIDS. He refused all medication and quickly died. Before his death, Mam' Dladla attended to her husband's sick mother, who also died. Her husband's younger sister died, following on the death of her son, and one of her own daughters quickly followed. A succession of deaths in her husband's and her own families meant that she had been in mourning for a period of five years. During the time of mourning, as is typical of many women in the region, she was not allowed to work. She had to abstain from undertaking the work of the abaphansi (those from below), the abalele (those who are sleeping), the ancestral shades. Customs pertaining to mourning and the continual mourning brought on by the deaths of those close to her meant that she had not been able to gather medicinal herbs from the surrounding hills. Mourning required that she 'sit down', her 'head bowed'. The special house in which her ancestral shades gathered, and in which the umsamo (shelf on which offerings were placed for the ancestors) was built, had disintegrated.

When I visited her, Mam' Dladla related a dream in which an old man sat shivering and weeping in the wet of the rain-drenched house of ruins. She interpreted her dream as a direct message from her deceased father that the house should be resurrected. The pitiful state of the ancestral shade she had seen in her dream marked the way in which the people's relation to the shades was being undermined. Mam' Dladla then undertook the repairs, despite her still being in mourning, carrying with her the awareness that her remaining daughter, who had recently married, was also HIV-positive. In rebuilding the house of the shades, she symbolically and forcefully tried to reverse the attrition of so many recent deaths in her family. She was able again to 'lift up her head' from mourning and to begin reversing the process that rendered her an ' $u$ uphuphe wesangoma', 'a degenerate sangoma', someone whose powers had faded, whose intellect had dulled. She maintained that the only valid response in the time of Mashaya Bhuqe (the Great Annihilator, a 'praise name' for HIV and AIDS) was to approach family members and neigh- 
bours with love. Naming is an important part of spoken isiZulu. Praise names, often involving a condensation of imagery, are given to most people, including powerful enemies. In the phrase, Mashaya Bhuqe, HIV and AIDS, is constituted as a powerful enemy to be placated and criticized through the giving of a name that underscores its power and devastating effect. (See Dowling 2004 for an exploration of praise naming in relation to HIV and AIDS.)

What is described here, then, are sediments of grief, laid one upon the other caused by death and loss; the effort that went into attending the dead and those they left behind; the erosion of work, as people held to customary practices of respecting the dead; and the effort required to repair relations between the living and ancestral shades.

The effects of HIV and AIDS on social and cultural continuity, identity and the creation of homesteads was eloquently captured in the words of the poet, Roman Khumalo, with whom I met on several occasions to discuss his poetry. His words convey the accumulation of grief, the 'topographical' way in which sediments of grief, attendant upon each death, came to augment one another. The poem is a demonstration of local Zulu oratory, carrying forward the art of praise-naming into a relationship with illness, something not unprecedented.

Maye! Ngalesisifo seNgculazi,

Maye! Mashaya Bhuqe.

Uyisifo esinjani kwezinye izifo na?

Izifo zonke ziyelapheka. Wen'awulapheki, Ufun' ukuqotha imbokodo nesisekelo,

Ufun' ukugojel' intsha namaphethelo,

Ufun' ukudla silaza udle lufumuka,

Ufun' ukudla khaba udle ntshakazo,

Hhawu! Maluju Ngculazi sekwanele. Yekanini ngemiqemane yezintombi, Imiqemane yezinsizwa, Amabhungu namatshitshi, Avel' awohloke okwezimba lenzala,

Edliwa nguMashaya Bhuqe, Wo! Lihlasele leligciwane, Lihlasela omame, lihlasela'obaba,
Alas! There is this affliction, Ngculazi (AIDS)

Alas! The-One-that-Annihilates-All.

What kind of illness are you that you are unlike all others?

All illnesses have cures. You do not.

You want to finish the women, the grinding stones, the foundations of the homesteads.

You want to gulp down the youth so that they come to an end.

You want to eat yesterdays' beer, as well as the unfermented beer.

You want to eat young crops, as well as the maize flowers of grown maize.

Oh! Maluju* Ngculazi, it is enough...

Oh! The girls' strength

The young men's strength,

Boys and girls not yet in love

They just fall down like ears of corn and grass seeds.

They are eaten by the Great Destroyer.

Oh! The virus is attacking.

It attacks the mothers, it attacks the fathers. 
Lihlasela uwonkewonke,

Hhawu! Maluju. Ngculazi sekwanele.

Maye! Ngentsha ngekusasa lalelizwe,

Maye! Ngamagugu alelizwe,

Awu! Ngirazisa ngezingane zethu.

Ezigojelwa nguMashaya'Bhuqe.

Awu! Ngezimbali zezwe,

Ezighol'umhlaba ngensada namakha,

Namhla zibunile kuselizintandane,

Ezikhihl'isililo sikaNandi zingenambheki,

Hhawu! Maluju! Ngculazi sekwanele.
It is attacking everyone.

Oh! Maluju! Ngculazi, It is enough.

Alas! Young people, the future of this nation,

Oh! The treasures of the nation,

I know our children.

They are gulped down by the Annihilator.

Oh the flowers of the nation,

They perfume the earth with their abundance.

Today they droop, orphans remain.

They weep Nandi's tears without a Guardian. $* * *$

Oh! Maluju! Ngculazi, it is enough...

* Maluju is an exclamation when disengaging from a fight.

$* *$ Nandi, the mother of the Zulu king, Shaka, together with the little Shaka, were chased from the homestead of Shaka's father, Senzangakhona, back to Nandi's family at eLangeni. Shaka was therefore abandoned by his father and was hence without a guardian (see du Preez 2004: 94). In a similar way, the poet implies that children who have lost their fathers to HIV and AIDS are without guardians.

(Extracts from the poem, Ibhekiswe Kwi HIV and AIDS, performed at the Durban City Hall HIVAN AIDS Exhibition, 5th August 2003, recorded and translated by myself.)

\section{Theoretical pathways}

\section{The vulnerability of the other}

When considering ethical questions in research concerning the experience of people living with HIV and AIDS, I begin to draw on the work of Emmanuel Levinas. Of all the philosophers of the late twentieth century, Levinas has perhaps conveyed to us most clearly the ethical responsibility we carry for each other in the aftermath of numerous, and sometimes unprecedented, social evils (see Levinas 200I, I999, I991, I989, I987, I985: 83-92). He suggests that violence exists in every political system, but that the evil it infers is unable to destroy 'senseless, incidental goodness in the human, the compassion proceeding from one private man to the other...outside all redemptive institutions, political or religious' (Levinas 200I: I20). Levinas characterizes vulnerability in terms of what he calls 'the face of the other'. In his view, the face divests a person of social roles, confronting the onlooker with the other's mortality. It is in being 
confronted by mortality that goodness and the human emerge (200I: 56 III.) Levinas is insistent that solicitude for the other person precedes the creation of knowledge. In his words, solicitude 'precedes a manner of speaking of thinking, precedes the desire to know, precedes objective thematization' (ibid).

Solicitude linked to responsibility in relation to the other is not divorced from a welling up of affection and warmth. Levinas speaks of the importance of responsiveness to the other, and an apprehension of their uniqueness 'isolated from all multiplicity and outside collective necessities' (200I: I08). Such a relation points to transcendence of circumstance; 'grace', as it has been named in religious discourse, and to which Levinas also refers (200I: III). It is a relation that refuses to place an individual within a common genus, and that consequently leads to a 'newness of rapport' between two persons interacting in the face of their mutual vulnerabilities. ${ }^{3}$ Levinas points out, that two persons are never alone in the world, because there is always a third to be considered. In incorporating the third, 'the necessity of comparing what is incomparable' arises. The incorporation of a third is the first violence, in that individuals are now compared, judged, and, although unique, are 'restituted to their genera' (200I: II6).

As anthropologists, we seek understandings of the world in terms larger than the individual and thus tell stories of more general pertinence. However, in attending to detail we hold the tension of the ways in which individual stories may disrupt our search for some kind of generality. In coming to meet the individual with whom we wish to interact with respect, we attempt to suspend preconceptions we may have concerning the cultural context in which our interlocutor is living. In our conversations with individuals, there is always a space in which they may surprise us.

A point arising out of Levinas' thinking that has particular bearing on my coming to know the dying and those who died, has to do with suffering. Levinas suggests that suffering encapsulates a state of solitude cut off from sociality. His work echoes Elaine Scarry's (1985) notions to do with the dissolution of language by pain. She argues that pain inflicted by torture divests the sufferer of meaningful language, and hence of the ability to communicate or give meaning to their pain. Torture implies the literal and figurative dismemberment of a self, as well as a person's separation from a shared world. Levinas (200I: 57) states that, 'Suffering is being closed up within oneself, this superlatively passive suffering is like the impossibility of getting out of it'. Certainly, as suggested in Chapter One, the suffering of those afflicted with HIV and AIDS is corporeally excruciating, and in Okhahlamba was accompanied by a diminishing sense of sociality, in that social bonds - often of the most intimate kind - were in many cases radically altered. People suffering from AIDS were sometimes isolated within their families, and at times even hidden from neighbours. ${ }^{4}$ In families where those afflicted by the disease were 
not rejected, an individual's self-worth could yet implode through the effects of radical alienation from their own bodies, of self-disgust and shame, and in the presence of the general circulation of pernicious forms of speech. ${ }^{5}$

Some of Levinas' concerns resonate with attending to the afflicted and the dying, and point to the importance of: compassion, responsibility, solicitation, warmth and affection, 'rapport from the unique to the unique', and an appreciation of the isolation caused by suffering. They are important to bear in mind when Mandla Shabalala's story is related towards the end of the chapter.

\section{On accompanying the dying}

Alphonso Lingus writes that meaningful conversation between individuals is 'subversive of some established order, some established set of values, or some vested interests' (1994: 72). He argues that in significant conversation, there is always the risk that people approach edges that may be sensitive, difficult, and may transgress what is considered normative. Within a relationship that emerges from paying attention to the extremely ill who may face death, we sometimes approach such an edge. The manner of approach, however, is best set by one's interlocutor. Ethical relationship evolves and is modified through time by allowing one's interlocutor to set the pace of exchanges.

In taking up the theme of pace in exchange, Lingus writes: 'To enter conversation with another' is to 'lay oneself open to surprises, contestation, and inculpation' (ibid: 88). He insists that the meaning and significance of what is communicated is not merely contained in spoken words. What is equally significant is 'the rhythm, the tone, the periodicity, the stammerings, and the silences of communication' (ibid: 90). In relation to my bearing witness to people who were dying, or in interacting with the relatives of those who died, pace and timing were of seminal importance, as was allowing pause for silence. The haste with which one may attempt to fill silence indicates, in my view, a researcher's own fear in the presence of the gravity of affliction, as well as a desire to do something where there may, on a level, be nothing that can be done.

Because language is a means of sociality, it always holds the possibility that something new or significant can be said that outstrips numbing clichés that come inevitably to describe the world. ${ }^{6}$ In paying attention to the dying, one hopes that in acknowledging and accepting their HIV status, the silencing involved in a widespread suppression of the cause of their illness will be, at least for the person concerned, reversed. When meeting a person about whom one may write, one does not begin from a position of understanding. Rather, understanding unfolds through time, and with the way in which the person whom one faces rises up to challenge or surprise. Of equal importance here is not only how to elicit free 
forms of speech, but how to witness corporeal presence in all its agony in ways that do justice to the sufferer.

Describing the pain of accompanying his mother as she died, of offering her his presence, Lingis shows the way in which language fails in the face of death. Although it is difficult to say anything, as all language seems inadequate in the face of death, it still remains important to say something. Lingus describes how it is not what is said that becomes important, but that something in all its inadequacy is said. It is at death that a 'rift opens up' between the saying and the said. In giving support to the dying, however, it is not appropriate to take over the tasks of the dying person through a misdirected solicitude (ibid: II8).

In a moving passage describing the touch of consolation, Lingus (ibid: I78-I79) points towards many things that I think important in learning to sit with the extremely ill. He writes:

The touch of consolation is not itself a medication or a protection; it is a solicitude that has no idea of what to do or how to escape. Its movement is nowise a project; one goes where one cannot go, where nothing is offered and nothing is promised. The touch of consolation is an accompaniment, by one mortal and susceptible to suffering, of the other as he sinks into the time that goes nowhere, not even into nothingness. The touch of consolation opens the path, in time of endurance and suffering, to an accompaniment of dying and finds brotherhood with the other in the last limit of his or her destitution.

He insists that the dying person's corporeal substance and suffering cannot be thought of as so much data for interpretation or intervention (ibid: I77). One cannot substitute one's own powers for those of the dying person. Corporeal or carnal suffering lies exposed and can only call forth one's tenderness.

\section{On writing and speaking of the dead}

Before his own death, philosopher Jacques Derrida came to speak and write of many of his illustrious friends in the wake of their deaths. In a set of collected obituaries (200I), he, like Lingus, expressed the impossibility of speaking in the face of a friend's death, but also insisted that 'silence, absence or a refusal to share one's sadness would be equally impossible' (Derrida I989: xvi). He outlined the dangers in speaking of the dead, dangers that are not easily circumvented. These included 'using the dead ... despite one's own best intentions, for one's own purposes' (ibid: 6). Tact and taste were required in writing of the dead. Yet Derrida knew that it was always a struggle to avoid bad taste, just as there is always the danger of narcissism or self-pity in the face of the death of a friend (ibid: 6-8). Even though each death is unique (ibid: I93), Derrida insisted that every time we mourn 'we add another name to the series of 
singular mournings', committing a kind of 'posthumous infidelity' (ibid: I6). Not only is the singular death taken up in the rituals and codes of mourning - codes that might deflect attention from the particularities of certain kinds of death - but the reiteration of death (and especially, I would add, the multiple deaths attendant upon AIDS in a circumscribed region) leads to a situation in which we can never be sure of the object of our mourning. In other words, a 'slippage from one death to another' occurs, implying a transfer of the sentiments of mourning (ibid: 8).

In 'Lyotard and Us', Derrida (ibid: 235) described how Lyotard juxtaposed 'the beautiful death', as outlined in ancient philosophy, to the exception of Auschwitz where ever since, to borrow Theodore Adorno's (2003: 428) phrase, 'fearing death means fearing something worse than death' (Lyotard i988: 88). The way in which people's deaths, and hence their erstwhile existences, were obliterated in the camps is born out by Lyotard, who writes, '[I]f death itself can be exterminated, it is because there is nothing to kill. Not even the name Jew' (ibid: IOI). In the beautiful death, death is rendered meaningful because it is preferable to life. The authority of the family, the state or religion gives the individual the order to prefer death. In both the beautiful death and its opposite, mourning is outlawed, in one case, because the former is the fulfilment of a life full of meaning, and in the other, because the very names of individuals are murdered (Derrida 200I: 127).

Of what relevance are Lyotard's notions concerning a prohibition or erasure of mourning to the particular deaths and ways of living and dying of those afflicted with HIV and AIDS in Okhahlamba and South Africa as a whole? In alluding to extreme cases in which prohibition of mourning is evident, I do not wish to draw an exact comparison between the Holocaust and other forms of genocide, for example, and the mounting deaths of many people suffering from AIDS in southern Africa. However, there are ways in which public mourning of such deaths is muted. At a local level in Okhahlamba, the cause of death was rarely made explicit at funerals. Many individuals withheld the exact nature of their affliction from neighbours and family. They carried their pain in solitude. There was an unspoken prohibition of speaking of some experience. At a national level, until quite recently, state policy towards HIV and AIDS patients had been ambivalent at best.?

In a lecture entitled 'The Liquidation of the Self' delivered on the I5th of July 1965, Adorno (2003: 430-43I), like Derrida, draws our attention to different kinds of death. When Adorno declared that there was something worse than death to fear, he was suggesting that fear lay in not only the obliteration of a person's physical existence, but of all traces of their having had a claim to a place or a name. Here the metaphysical consolation of death as the culmination of a rounded life is no longer possible to uphold. He writes: '[T]he reconciliation of life, as something rounded and closed in itself, with death, a reconciliation that was always questionable and precarious and, if it existed at all, was probably a happy excep- 
tion - that reconciliation is out of the question today' (ibid.). In the face of the specificity of death consequent upon AIDS, Adorno's insistence on the disappearance of a rounded life is especially apt.

\section{The treatment of death in anthropology}

In their accounts of society, many early anthropologists sought to show how death was contained within an overall social structure. The effect was to domesticate it.

In her study of death rituals of Inner Mani, Nadia Seremetakis (I99I) challenges the ways in which many anthropologists (for example, Durkheim I947 \& Radcliffe-Brown I933) contained death within presumed, formalistic structures of particular societies, as does Johannes Fabian (I973). In anthropological explanations, death rituals were viewed as one of a set of important life-course-rituals, including birth, coming-of-age and marriage. Death rituals were described as separating the dead from the living with the aim of reintegrating those in mourning back into everyday life. In spite of how the latter accounts shored off the effects of death in reshaping the everyday, some of the ways in which death may unravel social order were intimated in a variety of symbolic inversions still present in many death rituals (for material on Zulu-speakers, see Bergland I957: 364-8I, Bleek I952, Holleman I940, Krige i936, \& Tyler I89I. See also Jeffreys 1951). Although Van Gennep (I960), in his formulation of rites of passage, suggested that space was invariably created for liminality, or in-betweeness in passing from one social state to another, he concluded that rituals to do with rites of passage, including those of death, ended with the reintegration of the living into social worlds. In contrast to accounts of death rituals that bear the consolation of a return to social cohesion, Seremetakis asks us to consider mourning:

which acknowledge[s] the problematic nature of discrete beginnings and endings [where] there is never full restoration of social stability; that death, its representation, its discourses, and its performative elaboration can haunt society and become an essential collective metaphor of social experience beyond the margins of ceremonial performance. (I99I: 48)

With the accumulation of attempts to write about social suffering and terror (see Das et al 1997, de Boeck 1998, Ross 2003 and Valentine-Daniel I996), there is a growing body of anthropological work that acknowledges the eruption of the past into the present, the carrying of death and mourning into the ragged fabric of everyday life. It is to a similar process that I now turn, offering an extended description of Mandla Shabalala's illness and the ethical responses it enjoined. 


\section{Accompanying Mandla Shabalala in his illness}

\section{First meeting: October 2003}

On the 7 th of October 2003, on a hot day, Sizakele Mdunge, a homebased carer from a neighbourhood in Okhahlamba, accompanied Phumzile and myself to the home of a very ill man. We entered a small homestead through the kitchen, where we met the man's kindly mother and a young woman, Vuyiswa, his girlfriend. Vuyiswa was thin, her arms covered in scars from local wounds. She abruptly beckoned us saying, 'Here is the man who is sick'. The young man lay on a mattress in the adjoining room. His head was wrapped in an orange cloth, his body draped in an eiderdown. He greeted us in a strong voice that was unexpected, given his extreme physical condition. He seemed wracked with pain, his words punctuated by rasping breaths, his head rolling from side to side, his body shaking with cold despite the heat. He wanted us to assist him in obtaining the pension due to him from his place of work in far-away Johannesburg, and perhaps a disability grant that could contribute to living costs within the homestead. He described his symptoms, telling us of the searing pains over the surface of his skin and of sores that covered his body. His girlfriend drew back the eiderdown, revealing his shoulder. It was hugely swollen, the armpit a dry white, the skin stretched to capacity, an insistent watery protrusion. He did not want to go to hospital. In his view, hospitals did nothing for one - perhaps a small bottle of ointment would be given for his suppurating skin, a bottle that might last one week.

Like many others in his position, he had returned home when already very ill. Unusually, his girlfriend accompanied him. It was she who took out his identity document and his payslip to show us where he worked. Out of respect, I did not open his payslip to see his wage, although his girlfriend later suggested that I do so. It seemed shameless to me. I had already been invited to look at Mandla's swollen shoulder. I preferred to hear his strong, yet pain-filled voice. What was the best way of witnessing a man's pain and his simultaneous resistance to the state in which he found himself, of acknowledging the corrosive effects of his flesh?

Phumzile and I offered to try to get a doctor to visit him in his mother's homestead the following week. (Over-stretched doctors at Emmaus Hospital did not visit patients in their homesteads.) We offered to assist Mdunge to obtain a basic set of medicines for Mandla from the clinic. $^{8}$

Mandla's quest for money was not simply a preoccupation with immediate survival. It had to do with upholding relationships, with the ideals and expectations of a migrant son, strongly felt, even in the face of death. Like Nkosinathi in the previous chapter, Mandla had found work in the city and had failed to send money home to his mother. Now, in extremis, he had returned. He initially expressed guilt at coming 
home incapacitated without anything to show for his time in the city. His mother had received him without recriminations, unlike Nkosinathi's mother, who made clear her rejection of a son who had not shared his earnings from employment. ${ }^{9}$

Although we were successful in arranging for a doctor to visit Mandla in his homestead, his family organized transport for him, at a cost of R Ioo (\$ I4.30), to the nearest clinic the following Tuesday. The urgency of the situation spurred them on to make their own arrangements before hearing whether we had been successful in persuading a doctor to do a home-visit. Mandla told the clinic sister on his arrival that he was HIVpositive. The doctor in attendance placed him on a drip and began procedures necessary for his application for a disability grant. ${ }^{\mathrm{IO}}$ The doctor was also asked to write a letter to Mandla's employers about his illness and the necessity for sick leave. In the late afternoon, Mandla was admitted to Emmaus Hospital so that the abscess in his armpit could be surgically drained.

The following month, the family was forced to make another trip to the clinic, again hiring a car, as the doctor had forgotten to write the letter to Mandla's employers. It was subsequently prepared. Phumzile suggested that she fax it directly to Johannesburg to circumvent the need for Mandla and his girlfriend having to travel all the way there, as they had initially suggested. Later, she followed up the letter that she had faxed to Mandla's workplace by telephoning and speaking to the personnel manager. She was informed that, as Mandla had written a resignation letter, he was only entitled to monies accumulated in a pension provident fund, and that these would be made available to him within three months. After the latter communication, however, many interactions with the company ensued on Phumzile's and my part, involving letters, telephone calls and a memorandum of all of our interactions, in an attempt to secure Mandla's pension money. At the time, these efforts were of no avail.

\section{Speaking of HIV status, affliction and relationship: February 2004}

We visited Mandla again in February 2004. On the day of our visit he sat upright in the shade of a tree, an astonishing change for the better. We offered him a small gift of fruit and yogurt. After initial greetings, in which we had expressed our happiness at seeing his improvement, he told us for the first time, and without solicitation, that he was HIV-positive. His was not a new illness, he said. He had begun to get ill in I998. He visited several Johannesburg hospitals, including Hillbrow, the Johannesburg General, and Baragwanath. He had undertaken a further HIV test at the Oliviershoek Clinic, where he had gone to visit the doctor after our initial visit. The young woman, who had tested him there, had been gentle and kind. Although declaring his HIV status to us openly, Mandla insisted that he first became ill due to witchcraft at his place of 
work, where he said an ill-wisher had placed harmful medicines on the steering wheel of the forklift machine he drove.

During the visit - a visit close to Valentine's Day, to which Mandla referred - he said that he would never have survived without his 'darling', Vuyiswa, who had accompanied him home. They had met in Johannesburg. She was from emaXhoseni (the former Transkei) in the Eastern Cape. When he became so ill that it was time for him to go home, her friends had said to her, 'Yini ulandela ithuna?' ('Why are you following a grave?') They thought it best for her to abandon him to his fate. But she said that her ancestors had given him to her, and would not be happy if she did so. She encouraged Mandla to walk everyday and gradually he built up strength to walk to his grandmother's and sister's houses. She taught him how to slowly lift his arm so that he could wash his own body. This, she felt, would build up his strength, and it also gave him dignity.

As we left the Shabalala homestead, Mandla walked slowly towards the gate to shut it. Although he could walk, he did so as an extremely old man would - his hands shook and he shuffled, unable to hold his back upright. Yet through the gesture of closing the gate, he marked his presence as one who could still perform a useful task. The slow pace with which the task was accomplished had the effect of making it writ large, a visible act of importance. His old mother made way for him to complete the task, although she was more dexterous than her son. Her holding back became a subtle courtesy and an act of generosity.

\section{Withdrawal from the outside world: May 2004}

We next visited Mandla in May 2004. He was clearly in pain, his body covered with inflamed, perforated skin. Every position seemed to cause supreme discomfort. He angrily told Phumzile not to touch him. His anger indicated that he was in physical pain, but also that social niceties had become unbearable. He laboured to rise to his feet, insisting on standing on his own, and staggered around the house into the shade of a rondavel. We asked Vuyiswa for a pillow onto which he could place his head on the raised clay lip that surrounded the house, as the effort of sitting up proved too onerous.

We were joined in the shade by Vuyiswa and Mandla's mother, who had been repairing the homestead by smearing its walls with mud, a common activity in the dry, winter months. Vuyiswa ate a bowl of food that had been grown in Mandla's mother's fields - pumpkin, beans and maize meal. Phumzile then asked Mandla if he would like to tell the story of his illness into a tape-recorder. I sensed that it was not an appropriate request, given Mandla's obvious discomfort, which I indicated to Phumzile. I felt it would be more respectful to simply sit with Mandla and speak gently about whatever he chose. My intuitions proved correct, as Mandla adroitly avoided speaking the 'story of his illness', saying that 
he would prefer to get Vuyiswa to write it down. The effort of dictating a narrative to be written down, however, seemed beyond reach. Perhaps the anger, pain, and dis-ease generated by the illness could not be coherently rendered in words.

So we sat. Since we had last seen him, Mandla had travelled to Ladysmith, where a doctor had asked him to return regularly every month to receive new medication. However, Mandla informed us that he no longer wanted to travel long distances because the journey by crowded taxi was too painful. The pain was both physical and social, as his affliction was written across the surface of his body. Another reason he did not want to go to the doctor was that the effort of getting there required a painful walk up a steep incline to the main road in order to get transport.

Mandla informed us that he and Vuyiswa had lived a 'fast' life in Johannesburg. Brawls were not uncommon in the hostel in which they lived and entertainment there often revolved around the consumption of alcohol. At one time, Mandla fought brutally with a young man from his home area, nearly killing him. The man had recently returned to Mandla's neighbourhood after a long absence as a migrant worker in Johannesburg. Mandla no longer wanted to make his way outside the homestead because he was worried that the man might encounter him in his weakness and attack him. Given his condition, it would be easy for another to end his life. And for his life to end in such a way, without being able to put up a good fight, would be ignominious. Rather, Mandla wanted Vuyiswa to be given money by his mother to go and fetch the medicine on his behalf.

Although Phumzile offered to take Mandla to Ladysmith to get his medication, on the day arranged he did not arrive at the main road. She walked down to the homestead, the road being impassable due to the rains. Mandla seemed to be withdrawing increasingly from the outside world. Even though his mother and several older women in the neighbourhood implored him to go, it seemed he had reached a point of refusal. He would not go. He was too ill. He insisted that Vuyiswa go on his behalf. It was as if Mandla had come to a point where he would no longer travel the painful roads beyond the homestead. Some said that through his refusals he was indicating his wish to die.

On the above occasion, Mandla's mother informed Phumzile that she had been forced to ask neighbours to make wide detours around the homestead because at times Mandla walked around the yard unclothed. In part, Mandla walked unclothed because clothing caused extreme discomfort to his burning and itching skin, but it can be read, too, as a form of social protest in a context in which exposing the most private parts of one's body publicly has, at times, indicated extreme disgust at a social or political state of affairs.

In May, during conversations with Mandla's home-based carer, Mam' Mdunge, we began to learn more about the state of play within Mandla's family relations. Despite the apparent closeness between himself and 
Vuyiswa, during some of the visits we had made, Vuyiswa had on occasion taken money from Mandla's mother ostensibly to go and get medication for him. Instead she went drinking and 'wandering about the roads' ('ezula emgwaqeni'). Wandering was a metaphor for indiscriminate sexual encounters. Mdunge was concerned that she would 'bring the illness to the young men of the neighbourhood'. Mandla's state became difficult for Vuyiswa to bear, as, according to Mdunge, she was increasingly reluctant to wash his blankets onto which he had shed portions of his skin. She told Mdunge that it was all becoming too difficult for her. She wanted to run away, but she did not have the means to do so. She suggested that perhaps she should stand on the highway asking for a lift from truck drivers back to Johannesburg. When Mdunge spoke to Vuyiswa about the possibility of her being HIV-positive too, she vehemently insisted that she did not have the illness.

On a subsequent visit, Mandla complained to me and Phumzile about his neighbour, a young woman who claimed to have borne his child many years ago. The boy, now an adolescent, was behaving in unacceptable ways in the neighbourhood, at times stealing from homesteads and being extremely rude to older people. Mandla's sister, a woman who worked as a teacher, insisted that Mandla was the boy's father, but he denied it. His heart was unsettled, he claimed, because it felt as though someone had 'sold [him] a field' without his knowledge. Speaking metaphorically, he suggested that had he indeed been sold a field he would have claimed it by ploughing it. He insisted that he had not done so. The above ideas are condensed into the Zulu phrase, 'Ungidayisela insimu engingayilimanga' ('You have sold me a field without my having ploughed it'). As intimated in the previous chapter, a set of metaphors common in isiZulu links female fertility to passivity, and the womb to the idea of earth. In relation to these ideas, male sexuality is linked to images of working and fertilizing the land. Mandla did not want to acknowledge 'the produce' of a 'field' he had not 'ploughed' (a woman's son). His mother and sister were insistent upon including the boy within the family, and on recognizing him ritually. They had recently performed rituals introducing him to his father's ancestral shades, as the reason for his bad behaviour was attributed to the fact that he had not been properly 'seen' by his true ancestors. Throughout the boy's childhood, Mandla's sister had bought clothing for him. Mandla was adamant in distancing himself from the kinship claims advocated by his relatives.

During the same visit, Phumzile informed Mandla that his grant application was going through, and that he could receive food vouchers prior to the actual issuing of the grant money, and that the value of the vouchers would be deducted from the eventual grant payment. He refused to take the vouchers, suggesting that this was another way in which the outside world sought to cheat him. 


\section{Hospitals, humiliation and moments of joy: July 2004}

In a letter dated the 5 th of July 2004 , hand-delivered by her daughter to our office in Bergville, Mam' Mdunge, Mandla's home-based carer, addressed Phumzile:

\footnotetext{
My daughter ... We are not well. Here I still have a problem with Mandla who does not want to go to hospital, and he says he does not want to be seen by people, because he says he would rather die than be seen by people. Phumzile, it is now very difficult with Mandla because when he scratches himself he cries. He is short tempered and he does not have mercy ...
}

All these concerns about Mandla pointed to his increasing withdrawal from the wider world, as well as a partial setting of himself against the expectations of family. Not only did he view institutional domains outside the homestead with suspicion, but also relations within his family.

Phumzile and I went to visit Mandla the following day. At that point, it seemed we were the only people outside of his family whom Mandla was prepared to see. He told us of his anger at the unexpected visit of another researcher a few days previously, who had accompanied a group of home-based carers in the distribution of donated food to different households, including his own. He insisted that we were the only 'outsiders' he was prepared to see, as we were 'used to' one another and had known one another for a long time. We had slowly built our relationship and had learnt how not to ask painful questions, allowing whatever he chose to speak about to unfold.

Despite the sadness expressed in the letter, our visit in response to it proved to be one of the most happy. When we arrived at the homestead, Mandla lay outside on his back on the sunny side of the house, covered in a shawl. A small fire had been made in an enamel dish to keep him warm, it being a winter's day. Phumzile and I walked up to him and announced our presence by making the onomatopoeic sound for knocking on a door. He slowly sat up and greeted us. I offered him a bag of apples and Phumzile a two-litre bottle of sour milk (amasi) and several bags of enriched porridge made available by the state for AIDS patients. Mandla's mother was happy to see us. I thanked her for the delicious pumpkin she had given me on my previous visit. It had been a moving gift, firstly because she had grown it, and also because she supported her ailing family on a meagre old-age pension. Soon she emerged from her kitchen carrying the last pumpkin of her harvest as a gift for Phumzile and myself. She brought it out of the house to the accompaniment of a lovely song, a hymn: her body swaying to its rhythm. She said that she did not have the mouth with which to thank us, as her son was still alive because of us. Mdunge agreed, saying that when Mandla had come home in September 2003, he had refused to go to both clinic and hospi- 
tal. It was only with our visits that he had had the abscess under his arm drained.

The first payout of Mandla's disability grant was imminent, and he happily discussed his desire for fresh vegetables and how he would buy them with his money. Vuyiswa asked him if he would buy her a new pair of shoes out of this first grant money. She pointed to her plastic sandals and laughed. The sandals were not suitable footwear for the extreme cold of winter. She asked, after a pause, whether she would have to pay back the money for the grant in the event of his death. This was the only occasion on which the possibility of Mandla's death was overtly mentioned in our mutual presence.

Without our asking any questions, Mandla began to speak of his medical treatment. He told us about his use of Zulu medicines in conjunction with pills issued by the clinic and Ladysmith Hospital: the local inyanga who sold him izimbiza (herbal medicines) had told him that it was altogether in order for him to take infusions of his medicine together with pills from the hospital.

He also told us about his fear of hospitals and of what he perceived as doctors' fear in relation to his illness. Sitting on the grass embankment to which he had slowly walked when he became too hot from the fire, he described what he saw as the doctor's disgust at his changing body. The word he used for disgust in isiZulu was ' $u k u n y a n y a$ ', the term referred to in the previous chapter denoting visceral rejection.

Mandla explained that he would not want to be in a hospital if he could no longer walk properly to the bathrooms to relieve himself or wash himself. Vuyiswa said that when he had gone to hospital to have the abscess removed, she had found him unwashed, because the nurses would not bathe him or change him. Mandla recalled the humiliation of crying with pain when a drip was inserted. A woman who came around the ward to place plates of food next to the beds chastised him, asking loudly, 'How can a man be a coward?' Although the Sister in charge of the ward had in turn chastised the woman, telling her not to say such things, Mandla had felt the disgrace of this taunt. Lack of control over bodily processes and an inability to move and cleanse his own body sharpened the shame and exposure he felt at the hands of medical personnel.

As a counter-balance to his declarations of unease and lack of dignity, Mandla related a trickster-like tale describing a sojourn in Baragwanath Hospital in Johannesburg, where he had been admitted in I998 for tuberculosis. Whilst in hospital, he remembered that he had left RI200 in the migrant workers' hostel in which he was living in Johannesburg. He attempted to 'escape' the hospital by putting on a male nurse's uniform and making his way through what he described as security checkpoints. There had been many gates through which he passed. It was only at the taxi-rank that an official from the hospital recognized him as a patient, and sent him back. When Mandla was discharged, he was pleased to find that his money had not been stolen. 
Both Phumzile and I were moved by Mandla's stories and his openness in tracing particular vulnerabilities in relation to hospital care and how they intertwined with the intimate comportment of his body and sense of self. In the midst of the silent pause following the telling of his stories, Phumzile, with perfect timing, greeted Mandla with his clan name and the beginning line of the Shabalala praises, 'Mshengu Shabalala (the clan name), Donga LaMavuso' (meaning that the wall of the house of the Mavusos - a clan related to the Shabalalas - is being built), which seemed to restore Mandla's sense of dignity.

Mandla asked for uphuthu (maize porridge) and the amasi we had brought, and ate in a stance frequently adopted by local men whilst eating - legs widespread and bent at the knees, eating from a bowl of food on the ground between them. Vuyiswa served him and sat next to him. Whilst he ate, we asked her how she was. She replied that she had not been well and that she was experiencing pain in her upper back. It struck me then with conscious force that she, too, was ill. Although she was stronger than Mandla, the signs of her illness had been visible from the start - she, too, was thin, and her arms were covered in scars. Throughout our interaction with Mandla, our focus had remained on him - his illness, his preoccupations. Vuyiswa had been positioned as the one who took care of Mandla. She was the one who washed his blankets and his clothes, who brought him food, who travelled distances to fetch his medicine, and who lit the fire in an old enamel dish outside of the house to keep him warm in the winter sun. The moment in which Vuyiswa first mentioned her own pain seemed a profound point of rupture in which her suffering suddenly came to the foreground. It was a moment in which the ethics of paying attention were tested, and where, to use Levinas' phrase, the 'third' entered forcibly into 'the society of two'.

Despite my feeling of 'dis-ease' at the discovery of my own lack of attention to Vuyiswa, the afternoon turned out to be a joyful one. A month previously, Mandla's mother had bought a plucky little puppy from a neighbourhood family. Mandla and Vuyiswa named him Honey. Mandla described him as an inkunzi (a bull), because of his strength and persistence. Honey clearly recognized Mandla as the human to whom he owed allegiance. His antics made us laugh: undeniably, he brought lightness and joy to the homestead.

A few days after this visit, Mam' Mdunge came to see us in the office. Mandla's mother was very happy about the way in which her son had spoken so openly with us and that he had even been able to laugh.

Mandla soon received his disability grant. We were to learn, however, that he did not share any of the money with his mother, who was understandably hurt. Rather, he and Vuyiswa began to cook separately from the rest of the household, an expression of autonomy for one whose dignity had been sorely undermined, but an act that hurt his mother. 


\section{A windfall and instructions in anti-retroviral treatment}

In February 2005, Phumzile received an unexpected telephone call from a new personnel officer from the company for which Mandla had worked in Johannesburg, who explained that he had found all our correspondence in the files and that he had a cheque made out for $\mathrm{R}_{32,000}$ (\$457I.43) for Mandla; his long-overdue pension payout. It was with joy that we related to Mandla, his sister, and mother that he was to receive the money owed to him. He travelled up to Johannesburg with a friend to fetch the cheque. Phumzile helped him to open a bank account. On his return, the first things he purchased with his money were a double bed and a television set. Mandla said that he would assist his mother in repairing her house. He sent Vuyiswa home to the Transkei, giving her $\mathrm{R}_{3000}$ (\$428.57). It was not clear whether she would return to the homestead. He subsequently gave his mother Riooo (\$142.84), an amount that seems extremely small, given her support of him. He also wanted to give Phumzile and myself some money for helping him get his pension. We refused.

In March 2005, antiretroviral therapies began to be issued at the local Emmaus Hospital. At the end of 2005, Mandla's CD4 count was below 200 and he was ready to begin anti-retroviral treatment. He accessed the treatment on his own initiative after having attended three orientation lessons at the hospital, in which the importance of life-long adherence was impressed upon him. ${ }^{\text {II }}$ When I visited him in June 2006 , he was a different man. His face and body had filled out. His skin was smooth and healthy looking. He walked with vigour and greeted me with deep laughter. He told me that he did not need to attend a support group because he had dealt with his illness on his own from the beginning. He said that he watched programmes on the television he had bought with some of his pension money, which helped him remain steadfast in his fight against the illness. His responses did not surprise me, as they seemed in keeping with his qualities as I had come to know them.

When I first wrote about Mandla, he was still a very sick man. At the time, he agreed that I could tell his story, but he did not want it reflected back at him in written form because it would have be too painful for him to be confronted with a 'picture' of himself in a diminished state. With his recovery, however, he later welcomed a copy of his 'story' as I have described it.

\section{Drawing together threads from Mandla's story}

At certain points in our ongoing interaction, I saw Mandla taking up some of the attributes that an anti-hero might assume. Alongside overt defiance, he carried a degree of self-disgust that surfaced intermittently, folding into an experience of horror at the disintegration of his body - in particular, his skin - and his loss of control over bodily functions. In the 
midst of Phumzile's and my interaction with Mandla, he refused to recognize his son; he would not share food with his mother, although she had supported him when he was empty-handed and incapacitated on his return to the homestead; he refused for the time being to go to hospitals; his irritability could no longer be contained. He had had enough of a pain-wracked body, and wore his defiance by appearing without clothing in his mother's yard. Running alongside the above responses was Mandla's fear of going beyond the homestead. He felt he would rather have died than be seen by people.

On one level, he became a stranger to himself, not only through corporeal suffering but through the anger directed at his own family. It cannot be claimed that Mandla came to behave in an ethical way towards his mother or his son, for example. Yet through a reiteration of physical gestures, he insisted on claiming adult personhood. Examples of the latter insistence were born out in a set of everyday embodied gestures that, in the course of daily life, become invisible because they are taken for granted. The gestures were Mandla's insistence on getting up from the ground unassisted, the manly and powerful stance he took in eating, an insistence on being cared for in many ways by his girlfriend, the deliberate way in which he accompanied us to his gate to bid us farewell, his closing it behind us, and the way in which he pushed his voice strongly out of his body when we first met him, defying his physical condition.

Mandla seemed consumed with anger about the failure of the wider world, or at least the propensity of the wider world to 'cheat' him. His fears were compounded on many levels: the 'white man's economy' had failed him; his health had slowly imploded due to witchcraft; his 'double', in the form of a healthy young man whom he had at one point nearly killed in a fight, had returned to haunt him, not only with a mirroring of his erstwhile health and belligerence, but with the possibility of a swift death in contrast to the death that seemed to be steadily approaching through his long illness.

\section{The crafting of ethical relationships}

Apart from the practical ways in which Phumzile and I assisted Mandla - through facilitating a disability grant, liaising with his former employer with eventual success, helping to monitor and facilitate his treatment at the local clinic and hospital - we visited Mandla frequently over time. During visits he began to share some of his experience of being ill, as well as other concerns of importance in his life. Both Mandla and his mother came to express appreciation of our visits, of our coming to a place where Mandla chose to speak and to laugh.

There were two particular points in our ongoing interaction when we, as researchers, were challenged ethically. The first arose from the skilful way in which Mandla sidestepped the request to tape-record the story of his illness; the second was the realization that, in paying attention to 
Mandla, I had neglected his girlfriend, Vuyiswa. As can be seen from the above example, paying attention is not an easy thing to do. On the one hand, attention may be intrusive and one must remain alert to the ways in which an interlocutor may steer one's attention away from certain things. Thus Mandla chose not to relate the whole story of his illness, a refusal that was gracefully tendered. On the other hand, too close attention to one person may displace recognition of others' suffering, as was the case in relation to Vuyiswa and Mandla's mother.

Another memorable moment in our time together had to do with pace - the perfect timing of the moment in which Phumzile called out Mandla's clan name and praises - a human interchange that granted Mandla his dignity in the aftermath of shared vulnerabilities. This moment was important in relation to ethical considerations, in that it constituted a point in time at which trust was expanded. In telling us of his vulnerabilities, Mandla was met with a response that acknowledged them and that simultaneously affirmed that their disclosure had not diminished his dignity in our eyes.

Although these moments were particularly powerful, Phumzile and I came to realize that our unfolding interaction with Mandla conjoined learning to listen and bearing witness to Mandla's corporeal suffering. Paying attention involved not pressurizing him with questions when he was in pain, allowing him to set the pace and content of our exchanges, allowing ourselves to feel compassion, warmth and affection for him. We learned to sit with discomfort, including our own. In so far as we allowed Mandla space in which, as Lingis (I994: 88) puts it, to surprise, contest and inculpate our understandings, ethical ways of interaction emerged in the give and take of relationship and intimacy. We became aware of a process of reconfiguring ethical ground through time. It was also through time that we came to see our collusion in a failure of ethics in relation to Vuyiswa and Mandla's mother.

\section{Conclusion}

Adam Philips (2002: xi) draws our attention to the ways in which care for the other is not always unequivocally moral. He suggests that there may be unconscious ways in which our care is threaded through with more dubious aims. He writes:

If the best thing we do is look after each other, then the worst thing we do is pretend to look after each other when in fact we are doing something else ... [T]his distinction, upon which most of our morality depends, is often spurious because we are always likely to be doing both things at once. (Ibid)

As Derrida maintains, there are aspects of social life, including writing about and bearing witness to the lives of others, that may at times come 
close to breaching taste and tact. Yet I have taken this risk in order to write of the weight of death attendant upon AIDS in a particular region of South Africa, and about a particular individual whose story, as I have told it, may enable readers to begin thinking about ethics in relation to intimacy, compassion and attention - an ethics unfolding in the open horizons of relationship.

Levinas' insistence that we have a responsibility to the other when faced with their mortality is particularly apt in the context of widespread suffering due to HIV and AIDS. Apart from any practical assistance Phumzile and I may have given Mandla, part of our responsibility towards him involved a complex process of paying attention. The kind of attention paid required flexibility in the face of pitfalls where too much of a focus would become intrusive, or where too singular an attention to an individual obscured another's pain. Learning sensitivity to subtleties required solicitude. Part of solicitude involves an appreciation of an individual's uniqueness. Yet in the context of anthropological research, attention must move from the particular to the shared. Although the details of Mandla's story are his alone, some of the emotions he expressed, his struggle with health institutions, with his family and with the outside world were shared by many others. In 'accompanying' the ill, researchers may provide a space in which those who suffer find relief in sharing what is not easily shared with family or community members. It is also incumbent upon researchers to find ways of writing about the areas of social life that are rendered inaccessible by taboo and that are situated within spheres of intimacy. 



\section{Children and Youth in Pursuit of Care}

\section{Introduction}

I now turn to the lives of young people who lost one or both parents, many to the HIV and AIDS epidemic, in the Amatikwe neighbourhood of Okhahlamba. In doing so, I trace the ways in which the young people themselves often sought relationships of care with adults, including relatives and neighbours. A focus on everyday life enables an appreciation of the multiple and varied nature of the young people's lives and begins through a description of their relationships; a description that is at odds with the assumptions of passivity and unmitigated vulnerability circulating in discourse concerning 'AIDS orphans'.

In an essay inviting research to do with children in relation to geographies of political violence and structural inequalities that are in themselves violent, Veena Das and Pamela Reynolds (2003: I) acknowledge that forms of violence can be most fruitfully considered together. When they are treated separately, being poor is perceived as a condition not unlike an illness. It is constituted as a generalized lack where poor people are rendered passive victims, and yet paradoxically often blamed for their poverty. As a consequence, poverty is depoliticized. ${ }^{2}$ In contrast to the idea of considering children as passive victims, Das and Reynolds call upon researchers to 'focus on the child navigating the everyday with care-giving responsibilities and devising strategies of survival'. ${ }^{3}$ Paying attention to children, a task more difficult than is often assumed, allows suspension of 'the tendency to interpret [their] lives within the languages and scripts we use for understanding adults', and the shedding of 'assumptions taken-for-granted about normality and pathology' in relation to children's survival strategies (ibid: 2). The strength of Das and Reynolds' approach is to uphold what I shall refer to, for heuristic reasons, as the double nature of everyday life worlds - a consideration of the everyday life of children and youth as holding within them a 'continuous recreation of both belongingness and survival' (my emphasis) (ibid: I).

The spectre of the AIDS orphan, as it has circulated in global discourse across many forms of media, has linked the idea of parental death to various kinds of social pathology. In the most extreme cases, it is assumed that children who lose their biological parents through death necessarily remain without adult guidance, do not receive proper care, become homeless; and are in danger of not being socialized appropriately, and, therefore, of demonstrating criminal, anti-social behaviour. ${ }^{4}$ 
With commentators insisting upon such forms of vulnerability, children are emptied of the knowledge and abilities they may have. The ways in which they are often embedded in and commandeer their way through larger networks of social relationship that include both young people and adults are denied.

It is within the space of the insistence upon a patronizing form of vulnerability that assumptions to do with 'appropriate childhoods', implicit within child-rights discourse, become intertwined with intervention projects. The result is frequently a crude insistence on the promulgation of presumed ideals of childhood within particular localities. In many cases, imported knowledge utilized to shape an intervention is taken for granted, and may block any appreciation of local understandings. The ways in which globalizing assumptions may be inappropriate may therefore be submerged.

\section{Exploring further predictions}

In a thorough overview of literature outlining the social consequences of orphanhood in South Africa, and drawing on comparative studies undertaken in Botswana, Zimbabwe and Uganda, Rachel Bray (2003) has critically engaged with the tenor of predictions to do with the state of being an orphan, and suggests that many are sensational and alarmist. ${ }^{5}$ Through drawing parallels between arguments concerning children and the AIDS pandemic, and notions that youth who had participated in the political struggle for change in South Africa would have a detrimental effect on society once liberation had been achieved, she reveals the shared underlying structure of both arguments. ${ }^{6}$ In relation to South African youth, it was assumed that because they had sometimes participated in, or been on the receiving end of, extreme confrontations with the apartheid state, they would carry forward indiscriminate violence into the new society. In both sets of assumptions, fears around youth and children's autonomy are linked to the idea of the disintegration of social worlds. ${ }^{7}$ It is salutary to note that Bray argues that there is no evidence that AIDS-related deaths lead to greater degrees of criminality amongst 'unsupervised youth', or to a thorough disintegration of social worlds.

In an important paper to do with language use in relation to the construction of orphanhood in South Africa, Helen Meintjes and Sonja Giese (2006) insist that in a context where many South African children are marginalized due to poverty, the circumstances of poor, non-orphaned children may not be that different from those of children who have lost one or both parents. It is not uncommon for grandparents to contribute to the ongoing livelihoods of households and of children through supporting them with their old-age pensions, irrespective of whether children are orphans or not. This is because many parents are unemployed; the unemployment rates in South Africa, and particularly 
in KwaZulu-Natal, are staggering. Given the above realities, Sonja Giese et al (2003) recommended to the South African state that a basic incomegrant be distributed to all poor families, irrespective of whether children had been orphaned - something the state has thus far rejected.

Bray (2003: 15) and Meintjes and Giese (2006) point to a social, economic, and political history in which parents were, and still often remain, separated from their children for long periods of time, due to erstwhile apartheid laws and persisting patterns of migrancy related to the search for remunerated employment. Due to sets of pernicious influx control laws, the separation of parents and children was particularly common in rural areas, where both men and women inevitably sought work beyond their home areas. South Africa's children and youth have thus long been involved in fluid child-care arrangements whereby not only adults, but also children, have been mobile in pursuit of schooling, work, health care, and political safely. A body of ethnographic research in South Africa has highlighted the changeability of children's lives in general and their relation to multiple caregivers over time (see Jones I993; Henderson I999; Ramphele 2002 and Ross I995). Apart from the mobility of children between caregivers before the AIDS epidemic, positive values are attached to the range of kin upon whom a child may call for support (see Henderson 2003).

The above points do not mean that the long-term attrition of multiple deaths attendant upon the AIDS epidemic, particularly in southern Africa, has not and will not have a profound effect on social relations, and hence the lives of young people. ${ }^{8}$ Neither do they imply that children living within the presence of death do not suffer in ways that are hard to bear and even more difficult to describe. Statistical projections of deaths due to AIDS and concerning the numbers of orphaned children are alarming, and even if inflated, are cause for concerted action and concern. ${ }^{9}$ However, generalized, one-dimensional conceptions of poverty and AIDS - both forms of structural violence inflected with the political - are problematic. Textures of lightness, beauty, love, strength and conviviality, often equally present in social contexts of scarcity and pain, are excluded from analyses in an attempt to depict the gravity of the epidemic. I will thus argue that while we should not underestimate the devastating effects of HIV and AIDS on children's lives in South Africa, there is improvisation and dexterity despite the fractures within social worlds in which AIDS, and consequently death, is prevalent.

To my mind, there is something unethical about an obsessive fixation on points of violation or personal pain, particularly on the loss of parents and the meaning of that loss for individual children in a context of high HIV prevalence. The grief and loss that AIDS orphans experience in relation to their parents' deaths can only be approached obliquely. It is important for researchers to respect children's silences in relation to personal pain. It is preferable for children and young people to choose at which point they deem it appropriate to speak of such things, if at all. 
However, there may well be the possibility that grief related to AIDS deaths is not overtly acknowledged due to the stigma attached to the disease, and to cultural patterns whereby young children are 'shielded' from the death of a parent by adults who do not speak to them about it. ${ }^{\text {IO }}$

\section{Resistance to imposed notions of orphanhood}

Meintjes and Giese (2006) and Bray (2003) have pointed out that researchers' definitions of orphanhood vary, in that orphans are defined as those who have lost either one or both of their parents. The differences between having lost one or both parents are not always made explicit in widely circulated accounts. Local conceptions of orphanhood among African people, including the young people whom I knew in Okhahlamba, do not focus solely on the loss of biological parents. Rather, the condition of orphanhood, as locally described, embraced existential dimensions, and had more to do with destitution, alienation and a lack of belongingness. Theoretically, the idea of being orphaned could therefore be attached to a person who still had parents, but who had experienced profound displacement, for example, through war. To be orphaned in this sense was to be without moorings, social support and place. More philosophical implications regarding the state of orphanhood are also attached to older usage of the term in the English language (Meintjes and Giese 2006).

The young people with whom I worked in Amatikwe adopted the name 'Leaders of Tomorrow' (LOT, 'Abaholi Bakusasa') and rejected outright being called izintandane (orphans). Rather, their chosen name implied a determination to survive, and to contribute to future social worlds. In line with the many heroes and heroines of children's literature, or at least in the world's body of folk tales, these young people strove to sustain themselves in ways that suggested the coupling of adversity and strength. ${ }^{\text {II }}$

\section{Drawing on the inspiration of literature}

In breaking from stereotypical descriptions of childhoods, particularly those of poor children, I draw inspiration from Ben Okri's (I99I) prizewinning novel, The Famished Road. Although the book is an adult's description of life from the perspective of a child, it raises many pertinent themes: the importance of describing not only the lack and loss within such worlds, but also the creativity of children in negotiating the everyday. In his book, Okri takes on the voice of Azaro, a spirit child. In a set of ideas that mark the proximity of life and death in early childhood, spirit children in West Africa come to earth reluctantly, and are drawn towards early death in order to rejoin their spirit companions. However, Azaro, instead of rejoining his spirit companions, decides to live, as he cannot bear the suffering that his death will cause his mother. He there- 
by takes on the uncertainties of mortality through compassion - a compassion that he extends to his father, who at one point beats him severely. His father's cruelty is placed within a framework of understanding where he witnesses both his parents engaging in back-breaking work and various forms of humiliation to sustain their small family. Azaro is a wise child with prognostic powers. He acts as witness to the turbulent, poverty-stricken worlds in which he finds himself. These worlds are characterized by political and economic instability, and the uncompromising pursuit of scarce resources on the part of poor people and unscrupulous politicians alike. The book charts the physical intimidation experienced by the poor at the hands of the powerful. The ways in which life and death are closely intertwined is reflected in worlds where the living and the dead, the spirit worlds and the mundane, cross over into one another. ${ }^{\mathrm{I2}}$ The book describes a context of fluidity and flux, where cultural repertoires are shredded and reconfigured. Lines of continuity and innovation are etched. At no stage is this life viewed as pathological.

As has been intimated above, sociological categories frequently hold poor and ill people 'at arms length', and view them as categories of persons to be manipulated out of their lived circumstances. In contrast, in Okri's book, the harsh and the gentle, the unpredictable and changeable nature of experience are interwoven and viewed with understanding. The worlds of the young people of Amatikwe, as I will describe them, shared many of the characteristics of Azaro's worlds. These young people, too, were often capable of creative gestures in spite of the realities pitted against them. Although the group who called themselves 'The Leaders of Tomorrow' had all lost one or both parents through death, their everyday lives differed from one another, as did the nature of their individual suffering.

\section{The variable living circumstances of the children and youth of Amatikwe}

The Leaders of Tomorrow, who were involved in a gardening and chicken-raising project as part of an NGO-initiated intervention for 'Orphans and Vulnerable Children' (OVCs), counted seventeen girls and fourteen boys among its members. In 2003, there were also three 20-year-old youths in the group. In the same year, the younger children were between fourteen and eighteen years old.

Members of the project had lost one or both of their parents through death. The group was constituted in this way despite the fact that when setting it up, Zanele, the manager of the OVC programme in Okhahlamba and my research assistant, was challenged by adults who came forward to form a children's rights committee. They pointed out the similarities between 'orphans' and non-orphans in their community, particularly the fact that many children lived in conditions of extreme 
poverty. The adults suggested that it would be unfair to distinguish between orphans and non-orphans - not only in terms of some tangible similarities between children, but also in terms of the opprobrium with which the term 'orphan' was burdened in metaphoric usage in isiZulu. Even though the language deployed in the formation of the project referred to 'orphans and vulnerable children', in actuality, children and youth who had lost one or both parents became the members of the group and other equally poor children were excluded. ${ }^{\mathrm{I} 3}$

Most young people in LOT attributed their parents' deaths to isifuba (the chest); a reference to tuberculosis, an illness increasingly associated with AIDS deaths. None of them directly imputed the cause of their deaths to AIDS. Yet the ways in which they often described their parents' painful and protracted demise implied that, indeed, most had died due to the virus. The one obvious exception was the father of a youth who was killed in a road accident. Many of the young people, together with their current guardians, made reference to bewitchment as a deep causal reason for the death of parents. It was only in the children's creation of a play, 'Imidlalo Yethu' (Our Play), about life in general in Amatikwe, that the theme of AIDS and the deaths that it held in its wake was introduced (see below).

Ongoing visits to the young people in their homesteads, and in-depth interviews with them and their guardians, led to an appreciation of the varied circumstances in which they lived. I have pointed out that African children in South Africa have long been involved in networks of care that extend beyond care offered by biological parents. Drawing on the history of the spreading of care within kinship networks, I now refer to one of the children from Amatikwe, Sophie Zondo, a fourteen-year-old, who lived with her grandmother from a very young age. The reason for doing so is to demonstrate the ways in which parental absence pre-dated the AIDS epidemic. Sophie was conceived in a previous relationship before her mother married, and, as with many children in southern Africa, remained with her mother's people after her mother's departure for her new married home. In the patrilineal family structures of Okhahlamba, it was not unusual for a child to remain with her maternal kin when the father had not formally married the child's mother. Sophie's mother's death formed part of various forms of separation between herself, her mother and her father. Although Sophie's father, as far as she knew, was not deceased, he had long been absent. After having gone to Johannesburg to seek work when she was seven years old, he failed to return home to his father's homestead. Sophie's mother's mobility, however, did not diminish the pain of her death for her daughter.

\section{Sophie Zondo}

I was born here at Amatikwe. I lived with mother. I started living in this house [with mother's mother] when I was six years old. Mother then worked 
in Ladysmith [a large regional town in the uThukela District] and I was left with grandmother. I lived with my grandmother for a long time. Mother then returned. She later went again to work in Johannesburg. While she worked there, she found another man. She went to marry him and I remained living with grandmother, and still do. Grandmother sent me to school and mother helped her. Mother then died in 2000. She returned home. She was sick. She suffered from terrible headaches, and blood came out of her nose. She was well in the hospital when we visited her. The following day she left hospital with grandmother to come home. I was at school. I was told that she died unexpectedly that day. She died in this home. She was buried at her husband's place, at the Mdakanes over there. [As Sophie related the death of her mother she began to weep.]

Father left a long time ago. I was studying first year [at primary school]. He went to work in Johannesburg and never came back. We went home to the Zondos [her father's family] to look for him. We could not find him after he left for Johannesburg. No one knows where he is. The Zondos are at Mangweni. (Interview, Io June 2003)

Having suggested that parental absence is not only linked to death for the children and youth of Amatikwe, I now relate in detail the stories of three children and youth from the same community, pointing out the similarities and variation between them.

\section{Happy Mbhele}

When she was thirteen, Happy lived with her mother and sister in a house her mother had begun to build for herself on a hill opposite Happy's father's homestead. Happy's parents were unmarried. Happy nursed her mother before her death in 2000 , and also cared for her four-year-old sister. She remembered that she was in her first year at secondary school the year her mother died. As caretaker of her family, she would wake up early in the morning to prepare her mother's bath and to cook for the household. She then got ready for school - a 45-minute walk away. Sometimes, if there were early morning classes, she had to be at school at six in the morning. Happy was extremely thin throughout the duration of the research. Her clothes and those of her sister were old and threadbare.

Of her mother's illness she said:

Her body was painful all over. She had diarrhoea, messing herself [wayezihudela]. Some days she would say that she had sharp pains in her head. When she was about to die she said it was as if there was something beating her ... and she died. I can't explain what she really had. She was ill for a long, a long time. In the summer she had sores all over her body. (Interview, 5 September 2003) 
During the first formal interview with Happy, her evident stoicism was underpinned by anger. Her habitual set of gestures whilst speaking was to repeatedly pull at her clothes and to rub the skin on her arms. These restless movements may have unconsciously warded off, yet simultaneously reiterated her mother's suffering as manifest in a body covered with painful sores - suffering with which, as her mother's caretaker, she was intimately familiar. Happy insisted that her bravery was 'inherited' from her mother. Her capacity for endurance was learnt from her mother, a hard worker, who sold chickens and thatch-grass so that they could live.

After her mother's death, Happy and her sister went to live with her father's brother's wife, her mamkhulu (literally 'big mother'), a widow with six children. Happy seldom saw her father, who worked in Johannesburg as a taxi-driver. There was a time when the two girls went to live with her maternal grandmother, an isangoma (diviner). Happy complained that her grandmother was never at home and that there was no food in the house. She would leave the children alone for days while attending clients in distant areas. During her absences, they often did not have even a candle with which to light the house at night. Given the circumstances of their grandmother's home, the girls decided to return to their father's brother's household. Since their mother's death, their mother's relatives had not come once to enquire about Happy and her sister in their father's brother's homestead.

In December 2003, Happy and her sister visited their father in Johannesburg. She described the journey as follows:

It was neither bad nor nice. We went there and we lived with my father and mamncane [father's new wife; literally "little mother"]. Mamncane treated us like her own children until they sent us back here. The only thing that disappointed us was that they did not buy us anything. There was no umphako [food for the road]. We came back in the clothes that we had worn to go there. My father did not give us any money, not even for small necessities [izidingo ezincane] like school fees. Instead he wrote a letter and told mamkhulu to chase us away from here, and he told her not to ask him for anything for us. But mamkhulu is happy to stay with us. And she is better than anyone else. So we will stay here until we are able to stand on our own [ukuzimela]. Sometimes mamkhulu swears at us, but it is not so bad because we get smiles, and we are able to continue with our schooling, even if we haven't paid school fees, or are short of things for school. But it is okay. I am very happy with schooling because it means we will be able to help mamkhulu one day. Everyone has abandoned us, and we do not have our own mother. My sister and I passed school last year. My class teacher helps me with my work, even in subjects that she does not teach. Mamkhulu helps me, especially in isiZulu. I help my younger sister with her work. (Interview, 5 September 2003) 
In our interaction with Happy, it seemed that her own plight and that of her sister were the most difficult of all the children in LOT, because they could not find a secure place within their mother's family. In addition, their father refused to condone their presence in his own family because he had not paid ilobola (bridewealth) for their mother.

\section{Cebsile and Bongi Mazibuko}

The following account involving two sisters shows how Cebsile and Bongi, who in 2003 were seventeen and fifteen respectively, remained unsupported by relatives for a time, and initiated ties with neighbours in order to survive. Even during the most difficult of times, however, they did not abandon their wish to reconstitute their homestead. Their story shows, as does Happy's, the decisions that young people take in relation to their own survival.

Cebsile had two brothers, an older sister, and a younger sister, Bongi. As children, they had lived with their mother and father. When Cebsile was twelve years old, and in Grade Seven at a primary school in Amatikwe, her mother died. She too described her mother's death as due to isifuba (the chest). Her older sister looked after her mother while she was ill. After their mother's death, her older sister and brother went to the coastal city of Cape Town, a considerable distance from KwaZulu-Natal, to search for work. After her two older siblings had left to look for work there, it was not long before Cebsile's father also became very ill with isifuba. As the oldest girl in the homestead, Cebsile took care of him, leaving school for some time in order to do so. Cebsile's father died while she was in Grade Nine at secondary school. Her brother and sister, who stayed in Cape Town, returned for the father's funeral and then left again. During their absence and prior to their father's death they had not supported the family.

Cebsile was left with her second-oldest brother and younger sister, Bongi. They tried to support themselves by cultivating the family fields. The younger brother helped neighbours to plough during the planting season so that they would in turn help him to cultivate the fields belonging to his homestead. In this way, they were able to harvest their maize. Nevertheless, they did not have money for isishebo (relish) and other necessities. Consequently, their younger brother left to search for work in Cape Town.

The two girls, Cebsile and Bongi, were left alone. They decided to look after their homestead during the day and to sleep in neighbouring households at night. They began to ask neighbours for things that they did not have. It became extremely difficult to live in this way. Sometimes they slept without food and were afraid to ask for more from neighbours. They then wondered whether they should not leave their homestead altogether to live with neighbours on a more permanent basis, contributing directly to the maintenance of the households in which they stayed. 
They discussed which neighbours would be best to live with, and agreed that neighbours who demonstrated ubuntu (humanity) should be approached.

At the time of our first home visit to Cebsile, she was living in a neighbour's homestead. She sometimes also stayed in one other neighbouring homestead. Her sister, Bongi, lived with different neighbours further away. The people with whom the sisters lived were not relatives. In one of the families with whom Cebsile lived, the makoti (young bride) belonged to the same clan as the Mazibukos. Because Cebsile shared her clan name, she could claim a putative kinship relation with this family.

As Cebsile related her story, her deserted homestead was visible in the near distance. She said that sometimes she saw people stealing maize from it, especially at night when the moon was full. The furniture, however, remained untouched.

Although she had been taken in by neighbours, she was not treated in the same way as other young people in the homestead. She commented:

Living in this homestead does not mean that I live so nicely. There are things that happen that make me feel bad. Like when we come back from school, they tell me that there is no food. At the same time they will tell their own daughter to look in the pot and see what there is to eat. Sometimes they will tell me to make myself tea and to eat uphuthu [a stiff maize porridge] with the tea. They will then tell their own daughter to make eggs for herself. One thing I cannot come to terms with is that I had such a short time to call someone "mama" [mother], whereas others continue to call someone "mother", and are happy. (Interview, 7 September 2003)

In December 2003, Cebsile's oldest sister, who had returned to Amatikwe for the Christmas holidays, was struck by lightening (not an uncommon occurrence in the mountains), and tragically killed. The sister's death, adding to the weight of her parents' deaths, was particularly difficult for Cebsile to bear. After her sister's death, Cebsile and her sister Bongi returned to their family homestead, because her younger brother, a young man who was now in his twenties, had come back from Cape Town for their sister's funeral. He married a young woman from a neighbouring area and reconfigured their homestead by taking on the role of homestead head. The presence of a new bride seemed to revive the homestead. On my last visit to the two sisters, their brother and his young wife were building a new house for themselves in the old homestead. There were plans to rebuild one of the round houses that had fallen into disrepair. Bongi and Cebsile remarked how nice it was to have a young bride with them.

It is remarkable that notwithstanding all the difficulties they had endured, Cebsile and Bongi passed their school exams in 2003. At the beginning of 2004, Cebsile began Grade Eleven, and Bongi, Grade Ten. It was not clear, however, how the household would be sustained in the 
future, as their brother had not returned to his work in the Cape fishing industry. He led us to believe that he would return when there was a seasonal demand.

In January 2005, we learned that both Cebsile and Bongi had contracted informal marriages (ukugana) with young men, as had two other young LOT women. When young people 'married' in this way, the marriage was sometimes initiated or announced through staged abduction (ukuthwala). Informal marriage, where bridewealth had not been given to the bride's family, nevertheless involved elaborate exchanges of gifts between the young man and girl's family, including grass mats, mattresses, blankets and utensils. In these forms of exchange, presents were given not only to the living but also to deceased relatives. Through the intimate symbolism implicit in an exchange of items to do with sleep, warmth, eating and washing, the closeness between ancestral shades and the living were underscored. The metaphoric resonance of objects exchanged in courtship and marriage and their connection to the overall theme of care in the book are explored in detail in Chapter Five. The above forms of marriage left it open as to when bridewealth would be paid. In many older relationships in the region, bridewealth had never been paid or completely paid.

Returning to the story of Cebsile and Bongi, once the young women had gone to live in the homesteads of their 'young men', it was expected that they would take on strict forms of avoidance behaviour and respect in relation to their 'in-laws'. Their 'marriages' indicated the cessation of formal schooling, yet ensured a broader network of family on which to draw, an important safety net in a time of widespread deaths. ${ }^{\mathrm{I}}$ Such relationships also provided a social context in which babies could be unequivocally welcomed. Only time will tell whether these relationships will consolidate through the completion of bridewealth payments or dissolve, allowing other forms of relationship.

\section{Thulani and Vusi Hadebe}

In contrast to the above accounts of young people who lost their parents, the story of two other young sixteen-year-old boys, Thulani and Vusi, one of whom lost his mother and the other his father, is qualitatively different. The boys, whose fathers had been brothers, lived in adjoining homesteads alongside the boys' paternal grandparents, who lived in a large homestead on the top of a slope of ground below the impressive sandstone and basalt massives of Umdedelele Mountain. ${ }^{15}$ Beneath their grandfather's homestead were the homesteads of three of his sons, each laid out in a pleasing formation of separate round and rectangular thatched houses. One of the sons, Thulani's father, had died. To the one side was the homestead of a fourth son whose wife, Vusi's mother, had died. Three daughters-in-law lived in the cluster of homesteads with their children. The entire set of homesteads was separated off from 
others due to mountainous terrain. All these homes formed a close-knit network.

One of the grandfather's sons was employed by an electrical company. The grandfather, who had worked for many years in the coastal city of Durban, and his wife, gave general support to a large extended family of fifteen grandchildren and three daughters-in-law. Thulani, Vusi and Vusi's young sister, Phiwe, did not exhibit the same loneliness and consciousness of being misplaced as, for example, Happy. His grandfather lent Vusi's younger brothers a number of sheep to tend. Any lambs born to the sheep belonged to the boys. In the latter form of exchange, ukusisela - one in which assets were exchanged for care - the boys' grandfather demonstrated respect for them, and they in turn were growing up to develop a knowledge of animal husbandry, and a sense of responsibility. ${ }^{16}$

The loss of a father in Thulani's homestead and the loss of a mother in Vusi's homestead registered in different material ways in each set of dwellings. Thulani, who lost a father due to a road accident, lived in a well cared for homestead with his three younger brothers and sisters. The homestead comprised his mother's round house, his own square roomed-house, and his deceased father's house, recently constructed.

When I first visited Thulani after a long walk into the mountains to his home, I noticed that his room had been destroyed inside by fire, and was uninhabitable. It seemed that the room had burnt when a candle was left unattended. Yet the 'deep' explanation for the fire was that it should be read as a sign from Thulani's deceased father. Thulani's father wanted to convey the message that correct procedures had not been followed in caring for the dead and in accommodating his spirit in the world of the living. Thulani's mother explained that it was important to create a proper house for Thulani's father, even though he was deceased. Only after such a house had been constructed could Thulani live happily in his own room. In the months that followed, Thulani's grandfather and his sons built a 'proper' house to house the spirit of Thulani's father. Like all the other dwellings in the extensive set of homesteads, it was built with mud (udaka). In addition, 'modern' touches were incorporated large glass windows and a mass-produced carved wooden door. New furniture and a cement floor were installed, all in preparation for the inauguration of Thulani's father's spirit as a shade of the ancestors, a ceremony that usually took place six months to a year after a person's death. Once his father's spirit was properly accommodated, Thulani was in a position to repair his own house without there being further signs of his father's displeasure.

It was not unusual to encounter the close accommodation of the dead and the ways in which the dead registered in the lives of the living in Okhahlamba. Many of the 3I young people with whom Zanele and I interacted told us their stories while sitting in a room in which the treebranch named umlahlankosi (Buffeldooring tree, Ziziphus mucronata) - 
used to call back the spirit of their deceased parent to their home - was threaded through the rafters, and in which the horns of a slaughtered beast, marking the cleansing of a family after the parent's death, as well as their inauguration as a shade, were tied to the rafters. As ancestors were considered to be deeply involved in the affairs of the living, the children of Okhahlamba felt themselves to be in close proximity to the dead. Dreams were one way in which the deceased sent helpful guidance to the living.

Returning to the differences between Thulani's and Vusi's homesteads, in Vusi's homestead, where no adult woman was present, the houses, although clean, remained undecorated. The outside walls needed to be repaired with fresh mud. Neither did they display the usual bands of colour painted on the upper reaches of the outside walls of each dwelling, which traced horizontal lines around their circumferences.

Despite the material differences between Thulani's and Vusi's homesteads, the boys, both of a similar age, were firm friends. They lived their lives in large homesteads with three 'mothers', and in which their grandparents were respected and loved.

The above sketches of interaction with children and youth draw out different degrees of incorporation of the young within groups of kin. They share many characteristics with the life stories of all 3I of the young people with whom I worked in Amatikwe. They emphasize young people's pursuit of care within limiting circumstances, demonstrating in two cases the frequent mobility of children in relation to securing survival. They suggest the importance of linkages between children in creating a sense of well-being, a point often neglected in studies of children, and they stress the importance of long-term involvement with young people in tracing the ways in which families may disperse and reconfigure over time, as in the case of Cebsile and Bongi.

Submerged within the above tales is a sense of the layered cultural repertoires on which children draw, and with which they make sense of their experience. The accommodation of young people in social worlds is not, however, seamless. There is a great deal of pain and jaggedness in the reconstitution of relationships and means of survival. Insecurities attendant upon a devastating and highly stigmatized disease draw in their wake the 'shadow' sides of cultural possibilities. These have to do, for example, with accusations of witchcraft between kin and neighbours in relation to the deaths of loved ones, with the occasional suicide of young people in facing the social devastation of AIDS, ${ }^{17}$ and unremitting poverty.

\section{The pain of mobility}

In the above narratives concerning the household circumstances of some of the LOT members, I have pointed to the differing degrees of 
dexterity and mobility of children within networks of kin, as well as to their active pursuit of care within households. I would like to end this section of the chapter with a story in which one particular young woman's mobility takes on a clearly double nature, where fluidity is both a gift and an indication of turmoil. It is a story about the elusive pursuit of identity, an attempt to locate firm ground on which to pin a sense of self.

\section{Xoli Bhengu}

In an environment in which some children lived for more time with their mothers than with their fathers, due to fathers' migrancy or due to the informal nature of the relationship between their parents, in a public sense, children still marked their identities through their father's family. Children insisted that a sense of who they 'really' were became recognized and cohered through performing the rituals pertinent to fathers' clans. Young people who behaved badly attributed their 'unruliness' to the fact that their father's people, including their father's ancestors, had not properly acknowledged or 'seen' them. The shades were unable to see their descendents unless appropriate rituals were performed for them.

Xoli, an eighteen-year-old LOT member whose father had died, had two predominant ways of presenting herself. She was, on the one hand, extremely lively, loving, and exuberant. On the other hand, she lacked concentration and was renowned for being 'loud'. Other young people often remarked in her presence that she sang badly, disrupting the rhythm and harmony of collective song-making. (The term used for this common accusation is 'upabhimba'.) She sought variation and change, revealing an underlying restlessness, and frequently told us a story in which she doubted whether the woman with whom she lived was her 'real' mother. She expressed a great deal of pain around her lack of knowing.

Gloria, the woman whom she sometimes referred to as her mother, was reputed to have treated Xoli badly. She withdrew her from school at an early age to look after younger children in the homestead. In addition, Xoli was required to do much of the heavy work. When she, through her own initiative, found a job nursing a teacher's infant, Gloria would take all of her pay. Gloria also tried to prevent Xoli from attending a weeklong workshop with all of the other LOT members that I convened. Xoli insisted on coming, however, and hid her packing from Gloria in order to make her 'escape'. At one point in her young life, she had lived for several years with another family in Zwelisha, a settlement in Okhahlamba, when Gloria sought work in Durban. Xoli's memories of the Zwelisha family were happy. In January 2004, having asked the teacher for whom she worked for money for transport costs, she ran away to an 'aunt' who lived near Bergville. Xoli begged her aunt to inform her of her 'real' identity, and was told that her father's relatives lived at Nta- 
bamhlope, a community near Escourt, approximately II5 kilometres from Amatikwe. According to her aunt, Xoli belonged to the Bhengu family, her father's family. The aunt accompanied Xoli to a Mrs Bhengu, who turned out to be her father's brother's wife, a strict yet loving widow. This woman informed Xoli that she knew her mother's sister, who lived in Durban. Mrs Bhengu was a staunch member of a local church. To Xoli's delight, Mrs Bhengu invited her to live with her and sent her to night-school. Xoli proudly showed me and Zanele her school books when we visited her some time later, as well as a garden she had begun to cultivate. Mrs Bhengu told Xoli that if she began 'playing with boys' she would have to go and live with her father's other brother, who did not have such a nice home, and who had to support many children. Xoli herself was deeply religious and throughout our friendship happily offered to open meetings with a prayer or to sing hymns. The heightened theatrical resonance of local preaching styles seemed to suit her preferred forms of expression.

Mrs Bhengu, to whom she referred as mamkhulu (older mother), was of the opinion that Xoli needed counselling and that she should take her case to social workers in Bergville. To this end, a 'family conference' was convened by a social worker between Gloria, Xoli and her 'new mother'. The social worker informed Xoli that she was now old enough to live with whom she pleased. Throughout the family conference, Xoli was extremely brave and confronted Gloria about the treatment she had received. Mrs Bhengu described Xoli as having isibindi (a liver), an indication of courage. Xoli insisted on knowing who her 'real' mother was. When Xoli and Mrs Bhengu first related their meeting with the social worker, when we visited them at Ntabamhlophe, they stated that Gloria had admitted under pressure in front of the social worker that Xoli was the child of one of her father's girlfriends who had died, and that her father had brought her to Gloria, asking her to look after the little girl. Generally, people in Amatikwe and in Ntabamhlophe seemed not to know whether this was really the case, because Gloria appeared with Xoli after she had lived and worked in Durban for some time. No-one recalled seeing Gloria pregnant and people often remarked that Xoli's complexion was considerably lighter than that of Gloria's other children.

Xoli appeared to be very happy in her new home with the Bhengus. She wrote a letter to both me and Zanele, asking us to visit her there, which we did. An extract from the letter addressed to Zanele suggests Xoli's delight at the change in her life. It also shows her closeness to both of us and the ways in which our friendship over time supported her:

Oh my God! I thank God for taking me out of the mud. He has placed me in the light. Gloria threw away all my opportunities. Until I die I will not forget how she made a fool of me [udlala ngami] wasting my time. But at home [meaning at the Bhengu's place] they love me. They have sent me to night- 
school. I am so grateful, Ma[ka]Zethi [mother of Zethi, referring to Zanele], I am so happy, I am cool [ngipholile]. If I was not short of money, I would come to tell you nice stories that do not mean anything [ngazonixoxela ezimnadi izindatshana ezingasholutho]. ${ }^{18}$ I would like you to come here to Escourt, to Ntambamhlophe, to Golton with Patti [myself]. (Letter, 28 February 2004)

Xoli, however, soon began to meet with boyfriends when Mrs Bhengu went to church conferences. Mrs Bhengu, true to her word, asked her to go and live with her father's brother. Mrs Bhengu told Zanele over the telephone that she still allowed Xoli to visit her and to sometimes spend the night, because she loved the young woman and wanted to see her. She also wanted Xoli to feel that she was really a member of the Bhengu family. Whilst Xoli lived full-time with Mrs Bhengu, she managed to get an identity document (ID) - an often rare yet indispensable means of exercising the basic rights of citizenship: seeking work as an adult, voting in national and municipal elections, and opening a bank account. In order to get the ID, Mrs Bhengu used her own and that of her deceased husband as if they were Xoli's parents. Because of the difficulties associated with acquiring identity documents in Okhahlamba, many young people who did not live with their parents or whose parents were deceased appealed to people bearing the same surname to stand in for them as parents in order to get an official ID. If both one's parents had passed away, the difficulties in getting an identity document had to do with producing both deceased parents' identity documents and death certificates when submitting an application. If the parents had not lived with one another, it was often extremely difficult to access the document of the distant parent. Many parents died without death certificates because when families were too poor to afford the costs of a mortuary, they were buried at home without their deaths being officially registered. Although the state has recognized the diversity of family forms in South Africa at the highest level of policy development, the logistics of acquiring vital documents at the local level reinscribe the often fictitious centrality of a nuclear parental pair in granting to individuals their identity as citizens.

What was particularly important in Xoli's story was a simultaneous coupling of strength and fragility. This, together with Xoli's general demeanour, demonstrated a profound restlessness of spirit - a compulsion to be mobile. Yet running together with this was a resourcefulness and determination to make her own way in life. While Gloria often suggested that Xoli was 'crazy', to my mind she possessed a kind of incandescent 'craziness'. 


\section{Expressive genres}

Young people's 'shyness' in relation to Zanele and myself in the secondary-school classroom where we regularly met had, in part, to do with the ways in which children in Okhahlamba were taught repertoires of respect. In terms of the latter widespread practice, politeness was indicated by not initiating conversation with older people and by answering their questions in concise ways. In briefly answering Zanele's and my questions in the classroom setting, children and youth were performing a set of avoidances in line with the practice of ukuhlonipha. ${ }^{19}$ Ukuhlonipha implied bodily and verbal forms of respect that not only marked age differences, but also gender relations - those for example, between young brides and the male members of the families into which they married, where they were required to avoid eye-contact with older males, bow from the waist in their company and avoid words that contained any repetition of portions of their names. Brides also desisted from calling out the names of their in-laws and from walking across certain spaces in their homesteads.

In the Introduction to the book, I mentioned that I had employed a set of theatre games into our weekly meetings with the young people at their school. The effects of the games were that the younger children became more spontaneous and exuberant in our company. Due to creating an atmosphere of fun within the classroom, children and youth began to share with Zanele and myself some of their own performance genres: genres that combined self-praise and expansive bodily expression, coupled with an insistence on powerful presence. The genres came also to annunciate social bonds between the young people concerned. I give one example here.

In a cultural context where collective cooperation was greatly valued, there remained forms of expression, where individual qualities and skills in the deployment of physical movement in dance were acknowledged. The calling out of praise names for individual dancers, for example, was a way of singling out individuals for special attention - attention granted to an individual by his peers. The particular form of dance I will describe was one in which weight, and a sense of self, were given to an individual's embodied occupation of the world. This particular dance was one in which boys and young men participated. Each boy or youth danced individually, with the remaining boys and girls surrounding and supporting him by singing and clapping. Each time a boy raised his foot to the level of a shoulder and then returned it forcefully to the ground, often adding in the moment of the foot's contact with the ground the thrill of a slightly delayed stress in the overall rhythmic pattern of the song, the children called out one of the boy's praise names (isihasho sahke) - a praise name particularly attached to his specific embodied way of performing. The young people accompanying the dancer simultaneously clapped their hands on each stressed beat of the accompanying 
song, as well as on the delayed beat of the descending leg. Each praise name constituted a challenge to opponents and boasted of a particular dancer's prowess. The verbal delivery of each isihasho, in sequences of syncopated repetition, underscored the musical and rhythmic qualities of isiZulu. I write four izihasho below:

Ikopi lithi, 'keqe' (the tin says 'keqe'). This isihasho played on the association of the onomatopoeic sound of a metal cup clattering down onto a hard surface with the sound of the boy's dancing, the sound of his feet bearing down into the ground.

Ayakudla amadayisi (the dice are eating you). Here the implication was that the dancer in dancing so well was winning in a game of dice against his opponents.

Gijima uzungifice (run until you reach me). This dancer clearly meant to 'win the race' against the others.

Sibuz' ukuthi uvelaphi (we are asking where you come from). The phrase is a provocative declaration informing the other dancers that they are inferior to the one who is dancing, and that they have not been taught properly in the areas from which they have come.

One day, after having visited Thulani and Vusi at their large cluster of homesteads high up in the mountains, Vusi's younger sister, Phiwe, and Jabu, a young girl who was also a member of LOT, asked me if they could show me their dancing beads. I was delighted that they do so. The young girls ran immediately to their homesteads to don the beads of amatshitshi, young girls who have not yet entered into sanctioned relationships with boys. They returned with beautiful beads around their necks and waists. Those attached to their waists incorporated long strands that soared up into the air, creating an aesthetically pleasing calligraphy of ever-changing lines as the girls danced. As they and the boys took up a stance in which their upper bodies twisted away from their lower bodies, and in which the boys' raised arms took on the shape of spread cattle horns, they insisted that I photograph them. It was a joyous moment in which the young people declared themselves to me with visible pride. They lined up against the fading evening light in tall winter grass, the sandstone cliff-face of a mountain behind them.

Through the dances the young people shared with me in their school setting, I began to have a sense of the importance of dance for young people and of its multiple metaphoric associations. The joy with which Phiwe and Jabu showed me their dancing beads, and the four young people's insistence on being photographed, persuaded me that it was important to watch young people dancing on those occasions when dancing naturally occurred. I was later to learn how the young frequently 
travelled across the region to dance at the parties of older girls who had chosen a lover (ukuqoma), to dance at both formal and 'informal' weddings, and other ritual ceremonies, and that in doing so they practised not only the art of dance, but of courtship. The nature of the dances also set up playful rivalries between neighbourhoods, in which dancing teams would try to outshine one another. The young had therefore claimed for themselves powerful repertoires of expression that preoccupied them and that boasted of their particularities, beauty and strength. They also underscored the social ties between the young and the ways in which they could call upon one another for certain forms of assistance.

I now turn my attention to the play LOT members created through my facilitation. As mentioned above, in December 2003, Zanele and I took the group away for a week-long workshop on the south coast of KwaZulu-Natal. The play, in my view, became a form of embodied description of life in Amatikwe, as the young people understood it, and into which they wove some of their dances. Themes within the play were elicited from the young people themselves. I asked them to make a list of problems within their community, and of important institutions or people who were helpful within it. Each scene was then based on a series of improvisations in smaller groups around a particular theme mentioned in the above lists. The content, dialogue, use of language, and bodily comportment contained in the play emerged from the young people themselves, and included reference to HIV and AIDS without approaching too closely the contours of personal pain. The excursion not only resulted in the creation of a play, but brought the children, Zanele and myself closer together. Processes initiated at the workshop provided spaces in which children could accomplish something collectively, through hard work and enjoyment.

In their play, Imidlalo Yethu (Our Play), the 3I young people of Amatikwe showed that they were astute commentators on their everyday lives. In one scene, children are shown to be more familiar with the latest developments in social services than older people. The group was cognisant of the often exasperating dealings with government departments in pursuit of such services. In the play, children specifically 'teach' those acting the parts of grandparents about the niceties of grant applications, accompanying them to the local town to effect the reissuing of their identity documents. In the play, new documents are necessary because they have been burnt when the old people's homestead caught fire. The grandparents' documents are required in effecting successful grant applications. The two young people who act parts as the granddaughters acknowledge that they are orphans and that their parents have died of AIDS. They explain to their grandparents that a new child support grant supplied by the government has been announced at school, and that they, as izintandane (orphans), are entitled to it. ${ }^{20}$ The play contains scenes where traditional healers and diviners lament widespread death due to the virus (igciwane). In their practice they attempt to deal with the 
disease, as well as to locate cattle thieves and stolen cattle, cattle-theft being an additional and painful loss within many of their families. There is also a scene in the play in which the young people draw attention to crime. After an old grandfather had been robbed at an automatic teller machine (ATM) in town, having withdrawn his savings, he and his companion report the matter to the local 'Scorpions' - a group of men attached to the chiefly authority who attempt to locate the thieves and punish them. ${ }^{2 \mathrm{I}}$ The last scene in the play perfectly depicts the mannerisms of a Church of Zion congregation, where the prophet (umphrofethi) appeals to God to assist his followers in the time of the Mighty Destroyer (Mashaya Bhuqe), one of the evocative names given to AIDS in isiZulu. A desire to transcend the harshness of everyday life is conveyed in the scene through the relief that powerful, collective singing, dancing and prayer can effect. Young people's knowledge and playfulness is underscored in the play, and yet an intimation of the deeply unravelling effects of HIV and AIDS is given, of the desire to enter a completely different reality.

We see, then, that in the play, the young people were able to refer to HIV and AIDS, and even to act out parts as 'orphans' - the name given to them in schools and employed by NGOs - when in their everyday lives, it is generally too painful to describe themselves in this way or to state directly that many of their parents may have died of AIDS. The fact that young people themselves brought up HIV and AIDS as a theme threading through their play suggests that in acting out parts, they could point to areas of pain without discomposing themselves in the company of their peers.

\section{Conclusion}

The chapter has pointed to the dexterity young people brought to bear in drawing on networks of kin to reconfigure a sense of place for themselves, and yet alludes to a layering of pain that is not easily exposed. I have also suggested varied ways in which children and young people, who had lost one or both parents through death, were held within networks of kin. Even where networks began to be seriously compromised, the young drew on local repertoires of relatedness to create new bonds. This was particularly the case for Cebsile and Bongi, who entered into early informal marriages. Networks of assistance did not only involve relatives, or people with whom one could claim relatedness due to a shared clan name. Neighbours, too, in many instances tried to support children who found themselves alone, and brought them into their homes for periods of varying duration. The case of boys whose networks of relatedness began to seriously fracture is not that clear, however, especially if they remained without relatives, without much education, and 
without work, as was the case for one otherwise extremely talented young man in LOT.

I point to the importance of long-term interaction with young people in beginning to sense the layering of hurt they carried, as well as the accomplished ways in which they nevertheless reconstituted the everyday. Their accomplishments were based on a deep knowledge of their physical and cultural environments, including the way the dead were closely folded into the living world through their burial in homesteads, and through rituals that transformed them into ancestral shades who, it was believed, would continue to take a keen interest in the affairs of the living.

Habitual ways in which embodied forms of respect were re-enacted in a community like Amatikwe imply the difficulties of accessing the freefloating and self-reflexive voices of children and young people. Here children's experimental, playful and critical voices were often located in unusual social spaces, for example, in the creation of the play. They also erupted spontaneously into the spaces of children's work and play, including local performance genres revolving around dance and song. In the spaces of inventive conversation between children, language was shaped and played with. ${ }^{22}$ Similar spaces also emerged between Zanele, myself and the children after we had travelled an extended journey together over time, where habitual forms of interaction were suspended and where experimental openness was achieved, often through trust and mutual curiosity; where, to use Xoli's words, space was created for the young to 'tell nice stories that [did] not mean anything'. 



\section{Healers Negotiating the Local and the Global}

In Okhahlamba, death attendant upon AIDS was not perceived as the outcome of a neutral affliction for which there was no cure. Rather, death, on the scale with which it came to dwell among people, was tied up with the notion of a continuance of past social dissonance and histories of oppression, racial discrimination and dispossession. ${ }^{\text {I This }}$ chapter explores these understandings of a preponderance of death and illness, and how they intertwined with people's relationship with the state.

I approach the latter relationship tangentially by marking the ambiguities with which modernity was viewed from the point of view of two healers. To do so I draw on diverse conversations with them, as well as others, about the phenomenon of ill-health within the context of divisive histories in general. In their accounts, the failure of the wider world to support rural worlds is couched in apocalyptic terms, terms that reveal a sense of shared alienation from centres of power.

In tracing the life story of Ntuthuko Hadebe, an inyanga (the most common term for a diviner/herbalist of some kind), ${ }^{2}$ I seek to show how his relationship with worlds beyond the one into which he was born, and to which he returned, was expansive. In his life of migrancy, he welcomed opportunities through engaging tenaciously with the 'ways of the road' and by keeping 'his eyes open'. All that he encountered beyond his place of birth was coloured by the inflection of his calling as an inyanga. The second story is that of an isangoma (a diviner), ${ }^{3}$ Nonhlanhla Duma, a woman who was herself HIV positive and whose account of being called to undertake training as a diviner marked a return to an edge of difference, at least for the duration of the journey to her trainer's home. Her being summoned by an ancestral voice steered her, against her wishes, away from Johannesburg and its ways. Both accounts contain the importance of maintaining 'custom', not only in relation to healing, but in relation to a re-evocation of 'tradition'. Yet in the face of the AIDS epidemic, both healers insisted that they had no solution to the disease within their own healing frameworks. The isangoma also spoke volubly of the favourable effects of antiretroviral treatment.

The chapter considers the parallel existence of indigenous notions of health and healing and those belonging to bio-medicine, as well as their frequent combination. As has been outlined in Chapter One, conceptions of health shared by many African people living in Okhahlamba 
had to do not only with the health of the human body, but also with an appropriate arrangement of various configurations of social relationship. Therefore 'indigenous' medicinal repertoires, in addition to healing any physical manifestation of illness, sought to correct social relationships between the living, and between the living and the dead.

In amakhambi esintu, ukwelapha kwesintu (literally, 'the curative herbs of humankind, the ways of healing humanity'), much medicinal practice revolved around protection against pollution, whether this was of the individual, of homesteads, or of larger groups. Practices of strengthening and cleansing were carried on, in and through the body in processes of envelopment or ingestion: inhaling the smoke of medicines (ukubhema); being washed in the foam of medicinal plants (amakhambi okuge$z a$ ); steaming the body with herbal infusions (ukugquma); rubbing medicines into small incisions on different parts of the body (ukugcaba); drinking medicines that caused vomiting (ukuphalaza); receiving enemas (ukuchatha) that lead to the expulsion of faecal matter from the intestines; and the sprinkling of medicines over people and their environment (ukuchela). As suggested in Chapter One, the body, its exits and entrances had to be protected from substances directed with malevolent intent that sought to undermine the well-being of a person, or persons. ${ }^{4}$

In biomedical descriptions, Susan Sontag (2002) has alluded to the predominant use of military metaphors in explaining the body's workings. She writes that AIDS has a dual metaphoric genealogy. Like cancer it has been described as invading the body, and in considering transmission, it is experienced as a form of pollution, as was syphilis in the Igth century (ibid: IO2-IO3). It is precisely these ideas of invasion and pollution, together with their remedies - those of repulsion, expulsion and cleansing - that overlap with notions of illness and healing amongst many people in Okhahlamba. The discourse of powerful public health networks, often with global reach, is characterized by the description of disease as invading society and as marking off certain sections of the world's population as dangerously infected - in the case of HIV and AIDS, particularly southern Africa. Preventing the spread of disease is often couched in terms of fighting a war against an already existing or potential threat (ibid: 95).

The above metaphors bear a submerged apocalyptic thread, the idea that because of the smallness of the contemporary world, due to an unprecedented degree of human mobility, fatal disease has the capacity to travel swiftly and widely. In Okhahlamba, metaphors of war, invasion and of annihilation in relation to lesisifo (this illness/AIDS) were not unknown. They took on the contours of social worlds, including ways in which the past came to haunt the present in relation to racial, social, political and economic divides in South Africa. Specifically in the context of HIV and AIDS, whenever the depletion of the immune system was explained to groups of people in Okhahlamba, metaphors of soldiery were deployed. The term used in isiZulu for the immune system is 'the 
soldiers of the body' ('amasotsha omzimba'). As HIV takes its toll, it is said that the soldiers of the body are no longer strong enough to fight off invading viruses and germs. The common phrase for such depletion is, 'Amasotsha omzimba aphelelwe amandla' ('the strength of the soldiers of the body has come to an end'). A CD4 count of 30, for example, is then expressed as a person having only 30 soldiers left in the body.

In Okhahlamba, the body in which illness came to reside was open to invasion by alien or outside forces that subdued its protective soldiery. Military metaphors relating to illness and the body came to resonate deeply with a social history where a series of political and economic dispossessions to do with the social polity were made possible prior to and during colonial rule, and up until and during the apartheid era, themes that have been alluded to in the Introduction.

Here, I begin to sketch out the idea that dislocation, neglect and dispossession, being set apart, sometimes assumed a double valence for people who anchored their notion of home within the rural domain of Okhahlamba. A sense of being set apart assumed a double valence that was sometimes imbued with positive qualities, claimed in contradistinction to the wayward ways of the city. This tangential existence became a place from which to claim the remnants of pre-colonial identities - ones that were ironically shaped by the ossification of cultural difference and rendered 'inherent', 'natural' qualities by the apartheid state - and by the control of the institution of chiefly rule. ${ }^{5}$ The notion of cultural difference was sutured to a rural hinterland, as the appropriate place for the majority of Africans in South Africa to live. It is this place, which cannot be figured without its connection with urban life, that nonetheless facilitated a space in which people felt they could be themselves. An insistence on ethnicity and racial and linguistic divides during the apartheid era and the bitter weight of various forms of colonial dispossession, have had their lingering effects.

Debbora Battaglia's comments concerning nostalgia are resonant with what I wish to convey:

Nostalgia may in fact be a vehicle of knowledge, rather than only a yearning for something lost. It may be practiced in diverse ways, where the issues for users become, on the one hand, the attachment of appropriate feelings toward their own histories, products and capabilities, and on the other, their detachment from - and active resistance to - disempowering conditions of post-colonial life. (I995: 77)

Is it surprising then, that the ways in which people in Okhahlamba were taught about how the HI virus works within their bodies, using metaphors of depleted soldiery, had resonance with the body's territory being externalized into a parallel evocation of the social geography of the mountains, where the coherence of local homesteads was severely challenged through widespread deaths and loss of work in the cities? 
I now return to the two healer narratives, tracing their differing movements between the pull of 'modernity' and 'tradition', constructions that nevertheless are deeply implicated in one another and cannot be thought of separately.

\section{Exploring healer narratives: Ntuthuko Hadebe}

Ntuthuko Hadebe was born on the 5th of October, I948, the year in which the Nationalist Party came to power, bringing in its wake the ossification in law of apartheid policies that had some antecedents in colonial segregationist practice. Ntuthuko was born on a white-owned farm in the vicinity of the rural town of Bergville. Despite the difficulties he encountered whilst growing up, he was hard-working and resourceful. After his father's death, as the eldest son, he took responsibility for his brothers and sisters' welfare and, although he never went to school himself, assisted them in getting some education so that 'they could at least sign their names and write letters'.

After several unsuccessful attempts, the eventual acquisition of a passbook $^{6}$ was attributed by Ntuthuko and his family to a direct appeal made to his grandfather's ancestral shade. With pass-book in hand, he travelled to the City of Gold (Egoli, Johannesburg), learnt the trade of plasterer and began to work for an Italian employer - a relationship that would last for over 30 years. In the course of his work, he travelled to Mozambique and Malawi, and internally within South Africa to many towns on the Rand and to Cape Town and Plettenberg Bay.

In the I970s, Ntuthuko travelled on weekends to Moyeni, part of one of thirteen wards in Okhahlamba, to build a large family home that still bears the marks of his trade as a plasterer. Before his death, his father bought a plot of land there so that his children could put aside the limitations of life for Africans on white-owned farm land, and could easily journey to metropolitan regions in search of work.

As a child, Ntuthuko learnt a great deal about medicinal plants from his grandfather, who took him on walks into the mountains surrounding their place of work, in search of various medicinal plants, and who later requested that he search for these on his own.

After his grandfather's death, Ntuthuko quickly put his interest in medicinal herbs aside. As a consequence, he became extremely ill during his early working days in Johannesburg. He began dreaming important dreams. A spate of misfortune within his own family reinforced the understanding that he was being called to carry on the work of his grandfather as an inyanga.

After becoming an inyanga, Ntuthuko made the most of his journeys to other countries and of his wanderings within South Africa. Not only did he work as a plasterer to fulfil the building contracts his employer had obtained, but he made a point of meeting healers from other regions 
to learn about their particular ways of healing and the medicines employed in their work.

From I99I to I995, Ntuthuko worked as a taxi-driver in Johannesburg to pay off monthly instalments for a second vehicle he managed to acquire while formally employed - a taxi he bought on hire-purchase. Because of the amount of money required each month for the payments, he worked during the day, ferrying children to school, and at night as a taxi-driver, sometimes driving people between Johannesburg and Durban. He returned home in 2000 , to live with his wife and younger children. His extreme efforts in purchasing the taxi did not come without added pain: the fear that his wife and children would not have enough to eat during this period.

In a portion of the yard surrounding Ntuthuko's homestead lay the graves of his father and two older brothers, one of whom he thought had died of AIDS. There was also the grave of his oldest daughter who had succumbed to lesisifo, and who returned home for nine months, 'suffering from the afflictions of the feet and the head, vomiting and diarrhoea' (interview, 20 July 2004). She died shortly after the young man she was to marry had also died. He had wanted to begin transactions for the completion of a proper marriage, the transfer of ilobolo (bridewealth) to her father. Both Ntuthuko's brothers and his daughter died in 2002. He buried his mother in November 2003. Of his mother, he said that she had been extremely old yet not old enough to die ('Wayesekhulile kakhulu kodwa wayengakhulele ukufa') (interview, 20 July 2004).

Ntuthuko's life at Moyeni was a full one. He practiced as a healer and was an active member of a provincial healers' association. He was also well known at a local clinic, to which he referred some of his patients. Before inkosi (chief) Menzi Hlongwane was installed by the Zulu King, Goodwell Zwelithini, as chief of the Ngwane on the 26th of February 2005, Ntuthuko was one of the counsellors to the regent, Maswazi Hlongwane. $^{7}$

\section{Threads within a life}

Ntuthuko claimed that it was through 'paying attention' (ukunakisisa) and through 'keeping his eyes open' that he learnt to navigate his way about the world. Paying attention had enabled him to learn the various skills he had acquired.

Another theme that threaded its way consistently through Ntuthuko's talk was an exploration of how knowledge was acquired through exposure to pain; the pain and illness accompanying the call to serve the ancestral shades; the literal infliction of physical pain by a first employer when he was a young worker learning how to plaster; the pain of political conflict he witnessed during the days of 'Black Power' in the late I970s and 8os; and the aftermath of excruciating violence he saw prior to the I994 elections, when ferrying people by taxi at night. 
Ntuthuko was voluble in relation to some of the above experiences of violence. Of his employers, for example, he said that they 'hit' him, 'playing' with him, 'teaching him how to work' (interview, 20 July 2004). And that as a young man in Johannesburg, he learnt to defend himself against wily opponents through learning karate, having been forced to set aside the sticks used in learning the art of defence at his rural home.

In describing the horror of certain forms of violence that accompanied the emergence of a new state, Ntuthuko coupled violence with the actualization of prophecy:

At night I took people from hotels to the locations [Ntuthuko used the word "location" to refer to African townships]. I drove on the roads in a car at one and two o'clock in the morning. It was the time of the elections. You would find a person with his head cut off and lying on the road because people were fighting. If you drove around with the lights of the car on, and if you looked around, you might find dogs eating a person. You might find a person cut open with axes [izimbazo].

I have seen everything on this earth. May God keep us! When I was born, it was said that there would be many izangoma, many izinyanga and many prophets, water and fires. People at that time would rise up against one another. And the nations would rise up against one another. The nations have risen against one another. People have fought, cutting one another open, burning one another, doing all these things. That ended. People are dying like flies from this illness; they are being hit by cars, and they are killing one another. The things that I have seen in this country, on this earth are difficult in a way that is surprising. (Interview, 20 July 2004) ${ }^{8}$

Despite all the difficulties and pain that issue from an enmeshment with forms of violence, Ntuthuko concluded that it was through exposure to forms of violence that he was 'able to defend [himself] in life because [he] had been beaten in every way [ukuxhaphazeka]'. (Interview, 20 July 2005).

\section{The roads of the earth, the sky and of water}

In Ntuthuko's telling of the story of his life, there was an intermingling of difficult circumstances with an adamantine determination to seize opportunities, to develop skills within the broader world, and to fashion the means of confronting it. The predominant metaphor in his life-narrative was the idea of a journey, of the road. Learning on the road implied learning between places, learning on the move, suggesting that one is both outside conventional sites of learning and that one brings an improvisatory quality to the process of learning. Paying attention, keeping one's eyes open and learning along the way all came to characterize learning as a form of appropriation. In Ntuthuko's words: 
Everything that I have learnt, I have learnt from the road [Konke engikufundile ngifundele emgwaqeni]. So anything that I speak of, I keep on speaking about it, because everything I do I have found in the streets. Working, and everything else, I met with these things on the way. (Interview, 20 July 2004)

The ways in which Ntuthuko worked successfully with the harsh surfaces of aspects of his life are best captured in his phrase, 'I have learnt to navigate the roads of the earth, the roads of the sky and the roads of the water'. I will describe how these ways of coming to travel the world literally were also inflected with the particularly dense symbolic resonance of these elements within the calling of an inyanga.

In relation to learning the roads of the earth, although Ntuthuko was illiterate, he compensated for not being able to read maps or road signs by memorizing visual landmarks for the different routes along which he was required to drive a car, for example, from Durban to Johannesburg, as well as in his work as a taxi driver in Johannesburg:

I had to look very closely ... I had to know where the street [or highway] was within myself. I did not learn to find streets through reading maps. I had to learn through just walking ... I do not say that I cannot do this because I am not educated. I found difficulties, but I tried to find a way out of these difficulties. (Interview, 20 July 2004)

Ntuthuko tangentially commandeered the power of literacy through employing the writing skills of others in his work. Having completed secondary school, his daughter wrote the names of all her father's medicines and their usage on small slips of paper that were placed inside the profusion of lidded storage jars on the shelves of the shop counter in his fragrant pharmacopoeia. Even if he was not at home, his daughter and wife were able to read about the particular qualities of the medicines and, in uncomplicated cases, gave them out to those who required them.

Ntuthuko was extremely proud of different certificates, a few written documents that attested to his training in diverse ways: a membership certificate of the 'Trans-Herbalist Association' he received in Bloemfontein in I979; and the plastering certificate he acquired on the Rand in I987. Ntuthuko had a more recent certificate to mark his attendance at an AIDS training course in 2002. All the above documents were prominently displayed on the walls of his ikhemesi (chemist's shop), as was a picture of one of his heroes, Bruce Lee, cut from a magazine. The image referred to his having learnt karate, as mentioned above. The photograph on the certificate he received for successfully completing his training as a plasterer showed that he wore the hair of a diviner at the time, hair known as 'umyeko', indicating that he had already entered the water, a seminal part of the process of becoming an inyanga. 
Ntuthuko learnt to traverse the roads of the sky and the roads of the water during the course of his working life as a plasterer. He began to have repeated dreams that he was flying on 'a bird that laid the biggest eggs' (interview, 20 July 2004). He dreamt for eight months that he was flying through the air, sitting on top of the bird, clinging to its feathers. He asked his mother why he was dreaming such dreams. In time, his employer informed him that he wished to send him by aeroplane to Cape Town for a building contract. Although Ntuthuko was terrified, he began to fly, and it was wonderful for him. He thought at first that because there were no visible roads in the sky, the plane would not know where to go. He had experienced similar fright when travelling on a pontoon across a large expanse of water in Malawi. It accommodated a number of vehicles. People were nonchalantly reading newspapers in their cars. Ntuthuko felt afraid. What if the boat sank and they all died? How would his family get his body back from such a distant place? In the above-mentioned ways, Ntuthuko became accustomed to the roads of the sky, the roads of the waters and the roads of the earth.

In the image of flying on a bird that lays the biggest eggs, Ntuthuko was alluding indirectly to the-bird-of-the-sky, inyoni yezulu, that is said to bring lightning to earth. The bird dives to the ground to create a furrow in which to lay her eggs. In order to outwit the abelusi bezulu, the heavenherds - men who learn the art of controlling storms and who appeal for rain during times of drought - the bird seeks a way to lay her eggs when the paths of her multiple attempts are visible in forked-lightning. The many strands of forked lightning prevent heaven-herds from locating the eggs laid by the bird. Finding the eggs necessarily implies having some control over the lightning and where it will strike. ${ }^{9}$ Ntuthuko's dream suggested, rather audaciously, that he would acquire a degree of control over the forces of lightning, a skill of untold importance in the high mountains of Okhahlamba, where people are regularly killed by lightning. Indeed, in his travels to Mozambique and Malawi, Ntuthuko collected medicines for the control of lightning. Pointing out a root in his ikhemesi, he said: 'You burn it if there is lightning. If the lightning strikes it runs away. You can even sprinkle [ungachela] it'.

With regard to the importance of water within Zulu healing frameworks, Ntuthuko spoke of the significance of entering the water in being called as a healer, and of the importance of water as a medium of healing in both Zulu medicine and local Africanist churches. He spoke not only of the association of water with purity, but with life-force in relation to living waters, the ocean and the rain. He described the auspicious arrival at her home of an ithwasa (a newly initiated diviner) in the rain who had completed her training with him. ${ }^{\text {IO }}$

Of the dream that presaged his entering the water, Ntuthuko said:

I was always sick, and I had bad dreams. [Ntuthuko switched to the present tense.] I dream that I am in water, sitting in water with people. I have an 
abundant supply of medicines with me. I am in the water in this dream, yet although I am in water I am no longer in water. I sit in a sandy place where I have medicines. (Interview, 20 July 2004)

In drawing comparisons between the healing frameworks of izinyanga and of Africanist churches, Ntuthuko said:

The things that are done by izangoma, the Zionists do them also. Both the person of Zion, and the (i)sangoma burn impepho [helichrysum miconiaefolium]. The (i)sangoma goes to the water. The person of Zion also goes to the water. Like myself. [Ntuthuko, in addition to being an inyanga, is also a member of the Church of Zion.] I am truly a person of water. In everything I do, I am supposed to give praise to water. Sometimes I pray in the open fields. Early in the morning before I speak to people [who come to consult me], I pray in this home so that I, as God's servant, am able to look after everything. (Interview, 20 July 2004)

Of his ithwasa Ntuthuko said:

I took her to the ocean. I submerged her in the living water. I came back with her. Rain fell. I came with her from Durban and travelled with her until we arrived at her home in Qwaqwa. The rain was falling gently. It was beautiful. (Interview, 20 July 2004)

We begin to see how Ntuthuko's learning to commandeer the roads of the earth, the water and the sky in a literal sense, through travelling upon, on and through them, lay alongside the poetic ways in which the elements of nature were imbued with power in local healing repertoires. The coupling of these two levels of experience amplified the potency of notions to do with healing, as well as Ntuthuko's personal sense of knowledge.

\section{Nonhlanhla Duma}

\section{Returning home}

I begin Nonhlanhla Duma's story with how she was called to train as a diviner, (isangoma). It is a story of being inhabited by an ancestral voice, submitting to the will of a shade. Nonhlanhla was born in 1953, in the Nkandla district of KwaZulu-Natal. In I978, she became so ill that she had difficulty walking. The boyfriend with whom she lived in Johannesburg began to pay bridewealth for her. He, however, dreamt of her deceased father who insisted that he and his kin did not want him as a sonin-law. Both young people were perturbed by the dream. One day Nonhlanhla asked her boyfriend for Rioo (\$I4.28), not being clear why she 
had asked him for the money. Her boyfriend gave her the money and left for work. As soon as he had left, Nonhlanhla became aware of a voice, a presence communicating with her in a whisper:

Then a man, the voice came and said it was time. He said I should take the money and find transport. I did not know where I was going. I asked myself whether I was going home. I took the money, but my mind was confused. The voice asked me what I was going to eat. I was surprised, because I had not eaten for some weeks because of being ill. I did not like food. The voice told me to eat snuff [a substance often sniffed by healers]. I did not like snuff.

I had committed myself to the church. The amadlozi [ancestral spirits] forced me out of the church. I bought snuff at the train station shop. The first train came. The man spoke to me, but I could not see him. He whispered in my ears. The second train arrived. That train was going to Germiston. He said I should board the train ...

I did not buy a ticket, but went straight to the platform as he had ordered me ... I was not sure of the destination. I had no idea where I was going. He said, "Get into the train". I boarded the train. The ticket examiner did not bother to ask me for my ticket and I sat down. The train arrived in Germiston and the voice told me to get off ... I got off the train. And still my thoughts were not in order. "Stand on the platform", said the voice. I did that ... While I was standing there, a car came by. It belonged to a person from my home area ... The driver was a Mr Buthelezi, a son of my father's sister. He looked at me and said, "Is this my cousin?" I am not sure whether I answered him or not. I think I did. He asked me to get into the car.

The voice told me to get into the car. I did exactly that. My cousin ... drove straight to Nkandla, because I was so sick. He was afraid that I might arrive home already dead. People at home might disapprove if he [made any detours, because] I was not in a proper state of mind. He stopped at the Fort Louis train station. He bought food for me. I did not feel like food. I had snuff with me [in my hands]. The person with the voice ordered me to eat and breathe up the snuff. I had money, but no fresh clothes to wear. I had not used a cent of that money. I had not bought a train ticket. My cousin asked for payment for taking me down to Fort Louis.

At Fort Louis, the voice told me to get out of the car. My cousin was still in the shop. I got out. He [the voice] ... showed me some trees. The trees were umsinga trees. Their shape is round, and they have thorns. Their leaves are clustered together making dense shade. "Go and stand in the shade", said the voice. No one could see me when I stood there. "Yes", the voice said, "Go down and sit under the tree". I followed the instructions. "Look at him [the cousin] and see what he is going to do", said the voice. I stayed silent. Mzala [cousin] walked out of the shop and went straight to the car. He started looking for me. "He is looking for you. Do you see him?" the voice whispered. I said, "Yes". My cousin looked from side to side, asking people if they had 
seen me. Things happened in a way that is hard to believe. When one talks about things like that people think that you are dreaming.

Mzala then drove straight to my home. He informed the family that we had come down together but that I had disappeared at Fort Louis. They should come and search for me immediately. When mzala got into the car, the voice said to me, "A bus is coming. Come out of the shade". I walked out of the shade. "Get in the bus", he said. The bus was going to Empangeni. I did not know where I was going and where I would have to get off. I was not familiar with Empangeni. I fell asleep in the bus while it went on its way. While I slept I saw a homestead. It had Church of Zion Flags hoisted outside. The flags were divided into two colours, namely blue at the bottom and yellow. People said it belonged to the Nenes. He [the voice] showed me the dwelling I was supposed to enter. I saw a mother and many trainee healers [amathwasa]. Amathwasa walked in and out of the room. While I was busy with these images in my sleep, the bus was getting closer and closer to my destination. The voice said, "Wake up". I woke up. I asked the driver to stop the bus. I got off the bus. The voice said, "Turn around and look back". The homestead was behind me, and the bus had passed it. I turned and saw the homestead across the river. I crossed the river and climbed up to the homestead. I don't know what happened after that.

I woke up the following day when the mother of that home asked me my name and where I came from. I answered her. "Where is your home?" she asked. I told her. "Where have you come from right now?" she continued. I said I was from Johannesburg. "Can you give me your address?" she continued. I gave her the address. It was then that I felt human. She wrote a letter to my family. After a few days my people arrived. They gave her permission to proceed with her work [with training Nonhlanhla as a healer]. (Interview, 27 May 2003)

Nonhlanhla's story suggests being called in a dissociated way to a 'place of difference', a journey marking an embodied 'sloughing off' of the 'modern' world and its trappings, a journey into which the magical is progressively inserted. Being inhabited viscerally by a voice of an ancestor, and submitting to its instructions, suggested a state of being radically different from privileged, rationality within the context of modernity. It was also a voice that contested a predominant notion of discrete subjectivities. The voice dictated that Nonhlanhla only eat snuff, a substance that enhanced her sensitivities to the shade who had come to inhabit her. Her protection by the shade ensured that she was not discovered by the ticket-collector on the train for not having paid her fare. The shade ensured her invisibility when it required her to leave her cousin to take another direction in her journey. All the above transgressions, with their attendant forms of protection, suggested the assumption of a way of being that marked Nonhlanhla off from what was overtly acceptable in places dominated by rational knowledge systems and their productions. Nonhlanhla's place of training was communicated to her in vivid detail 
in her dream. It was a distinctly rural home, busy with the promulgation of a form of knowledge that was submerged in the popular culture of the place from which she had come, and where she began to feel human once she had arrived. Her story then marks a path in which the ways of izangoma were permitted an increasing visibility and acceptability in the course of her journey.

Although Nonhlanhla could not separate herself from the city and its ways in an absolute sense, her story nevertheless is an arch of movement, opposing that of Ntuthuko's ever-expanding world as I have described it. Whereas Ntuthuko sought to travel with ways of being an inyanga into spaces where technologies of modernity were predominant, Nonhlanhla found herself being recalled to a rural place, where she continued to live after her training, and where the illusion of separation could be upheld. It is of relevance that prior to being called to the place of her training by the voice that inhabited her, she could not carry out the domestic work required of her by her white employer. She felt extremely ill whenever she tried to do any task. She explained the waves of illness as a manifestation of the refusal of the shades to allow her to do work for 'the white man', insisting that she leave to do work for her 'own people'. In many ways, Nonhlanhla's powerful experience points to the ways in which histories mark the body and come to dwell within it.

\section{Ties between the living and the dead, a conduit of knowledge}

Both Ntuthuko and Nonhlanhla insisted that the work of the ancestral shades was different from working for a wage. A healer could not initiate the work. Rather, the work of the ancestral shades appeared intermittently in the ongoing life of a healer due to the shades' prompting. The arrival of people coming to consult a healer was presaged in their dreams, as was appropriate treatment. Being a healer implied that one was inhabited by an ancestral shade that had chosen to bestow upon one the gift of divination and/or healing. The precise nature and extent of the gift given was also dependent on the shades who chose one. It was they who could withdraw their gift if one was no longer seen as a proper conduit for their intervention in the affairs of the living. It was, therefore, a relationship in which a healer literally embodied an ancestral shade or shades in their person, and that insisted on sustaining relationships between the broader community of the living and the dead. It enacted a form of social identity that insisted on shared qualities between the living and the dead in particular clans; a strand of identity in which it was impossible to extract the individual utterly from their embeddedness within a body of kin. 
Nonhlanhla expressed the hierarchical relationship between ancestral shades and the people through whom they worked, a hierarchy that was implicit in all relations where respect was due:

The work of an ancestral shade [umsebenzi wedlozi] is work that marshals itself [umsebenzi ozilawulayo]. It depends on how it has been given to you, on those who control you, who own the work [abanikazi bomsebenzi, the shades] and how much they want to give to you. (Interview, I5 June 2004)

Of the way ancestral shades indicated how a person consulting a healer was to be treated, Nonhlanhla said:

When you are asleep, your people will come to you. They will tell you which medicines to take and how to prepare them, and they will inform you that a certain person is soon to arrive. Even as you mix the medicines, the person will arrive. That which they have told you about is what you will use to touch, to heal that person [Lowo ababekutshela wona yiwo uzowusebenzisa ukuthinta lowo muntu]. You do what they have told you to do and the person will live and be healthy. Then the person will say, "She is a good healer, She raises you up even when you are dead, this expert healer [ukhokhovula]". (Interview, I June 2005)

Opposing the idea of being knowledgeable and an expert, Nonhlanhla used an evocative metaphor to describe the isangoma as a medium:

You are just a log, a tree-stump on which your people sit. You are a messenger. You do things because those who are no longer here work with us who are living. [Uwugodo wena abakini abahlezi kulona. UYisithunywa sokuthi yenza ngoba abangasekho basebenza ngathi thina esiphilayo.] (Interview, I5 November 2005)

With regard to the ongoing relationship between the living and the dead, and the ways in which the gifts of ancestral shades came to reside in the living to ensure threads of continuity between ancestors and descendants, Nonhlanhla proclaimed:

There is suffering that enters a home because of not paying attention to the old people who are asleep [abadala asebalala, the shades]. They are people, as we are people. You must not be misled. Obviously we are misled because there are many different beliefs. The shades are alive as we are alive. It is only the flesh that is below, that disintegrates. The shade is still the person because the spirit is still the person. Let me put it this way, if I sleep here [die and am buried in the earth] my flesh will be eaten by the soil. [Ake ngithi uma mina ngilala la inyama yami izodliwa yinhlabathi.] I will sleep [die], but my shade will be left to guard my home and my children. [Ngilale phansi kodwa umphefumulo wami uzosala uligadile lelikhapa lami nalabantwana 
bami.] My spirit can enter this child. [Umphefumulo wami ungavukela kulomntwana, indicating her granddaughter who was present.] Say I have been given ability, a gift without shortcomings. I have goats and everything [given as payment for having healed successfully]. I want to give this ability, my talent [lelithalente] to my child's child. At the time that I give this to her, I have risen up in her, in her body. [Ngesikathi ngimnika loko mina sengivukele kuye emzimbeni wakhe.] It is my spirit that I will use to work with her. At the time when she greets the shades she will say, "Gogo, ngiyakhuleka kuwe. [Grandmother, I am respectfully putting a request to you.] Here are the people who have come. They are in need of this and that". I am the one who is going to talk through her. I am going to say, "Child of my child, the people, who have come with respectful greetings to make a request are troubled by this and that. In order for you to help them with their problem, they must do the following". That is how it happens. (Interview, I5 June 2004)

Just as Nonhlanhla described the respectful relation with those who granted her powers, so she described a respectful relationship with the natural environment from which she garnered medicines. The topography of Okhahlamba, with the exceptional beauty of its towering mountains, rushing streams and indigenous forests, constitutes a powerful presence in the lives of all who dwell there. Different parts of the natural environment are imbued with autochthonous powers. The powers of waters, mountains and forests, including that of Woodstock Dam, ${ }^{\mathrm{II}}$ are associated with great snakes that are the manifestation on earth of the overarching power of the creator, uMvelingqangi, the Lord-of-the-Sky. ${ }^{\mathrm{I2}}$ The great snakes, too, have significance in the calling of a diviner who, on entering the water, encounters the king of all the ancestral shades in the form of a large serpent. It is this serpent that sits upon life-giving medicines in the water, granting them their curative powers. It is this serpent that is 'God's animal'. Nonhlanhla's reference to the importance of paying respect to such powers while undertaking the work of the shades - powers that inhabited different parts of the landscape - has resonance with what has already been explored in relation to Ntuthuko's narrative. In the following quotation, she speaks of paying respect to the 'owners' of different portions of the natural environment:

You speak respectfully with the owners of the mountain, because the mountain does not belong to you. You ask respectfully, saying that you have come to request a certain kind of medicine, to ask that they give this and other medicines, too. As you dig, having asked appropriately, other medicines will appear in one place, because you have asked nicely.

You must not listen to people, when they deceive you, saying there is a place without a king [inkosi]. There is no place without a king. The mountain has its own king. The river has its own king. The forest that is on the mountain has its own king. [Intaba inenkosi yayo, umfula unenkosi yayo, ihlathi elisentabeni linenkosi yalo.] (Interview, I5 November 2005) 


\section{The politics of illness}

\section{Explanations of the origin of lesisifo}

Nonhlanhla became a member of an anti-retroviral (ARV) rollout programme, the Broad Reach Healthcare Programme, ${ }^{\mathrm{I3}}$ in June 2005. The programme, supported by American state funding, initiated a rollout site around the towns of Bergville and Winterton in Okhahlamba in what is known as the Eleven Settlements, freehold land areas, and also around the town of Winterton and in parts of the Cathkin Valley. In March 2005, Emmaus Hospital began an ARV rollout programme for all i3 Wards in Okhahlamba, and planned to decentralize the ARV rollout service via the five clinics in region. ${ }^{\text {I4 }}$

Prior to training as a facilitator in Broad Reach, where her responsibility was to bring HIV positive patients from the community in which she lived into the programme, Nonhlanhla's explanation for Mashaya Bhuqe (The Great Destroyer), for lesisifo (this illness), became intertwined with the re-evocation of the divisions and suspicions of South Africa's past. She suggested that the kind of death associated with AIDS had become more prevalent since the first democratic elections in I994. Many people thought whites (abelungu) had deliberately infected African people with the virus, so as to finish them off once and for all. A final and insidious attack had to do with jealousy on the part of whites, who could not accept that black people had the vote.

Phumzile encountered similar talk while taking taxis, filling up a vehicle with petrol at a petrol station, and in many other public spaces. Some stories hinged around the idea that 'poor people's food' - food purchased at country stores where white shoppers did not go - was infected with the virus. It was thought that condoms themselves were deliberately infected with the virus, 'giving it to the young people'. Several individuals asked Phumzile if she had ever held a condom up to the light to see the 'worms' reflected there.

As late as the 30th of September 2005, one elderly man in a focusgroup discussion made up of older men, hosted by Phumzile, argued that it was since young people had been allowed to vote that they had begun to die quickly. Indeed, it was being able to vote that had caused their deaths. This was because, according to him, new policies encouraged young girls to use contraception, something that 'killed their natural fertility'. He also claimed that the new government was giving free money to young women (the Child Support Grant) ${ }^{I 5}$ and thus encouraging them to give birth. Encouraging them to do so had led to their deaths. He declared that the present government had 'killed this generation' ('uHulumeni usibulele lesizukulwane'). In the statements of the old man, as well as those of Nonhlanhla above, we see that the divisions of the past became combined with dissatisfaction with one of the overt faces of the current state, the administration of social welfare. In addi- 
tion, they were overlain with the perceived breaching of patriarchal authority structures, and the manipulation of sanctioned notions of fertility through bio-medical techniques.

Another man in the discussion group maintained that young people were dying because they frequented medical doctors. It was suggested that the young 'ran after' doctors because they no longer wanted to employ indigenous means of healing, namely vomiting (ukuphalaza) and the use of enemas (ukuchatha). The reason why the young were getting sick was that they visited these doctors who finished them off ('Baya kulabo Dokotela ababaqedelayo'). The old man in question did not frequent clinics or the hospital and attributed his ongoing state of health to his refusal to engage with the institutions 'of the whites'.

The above ideas clearly reflect local experience concerning a crisis of modernity, the consequences of abandoning 'custom' and a general distrust of 'foreign' institutions, seen to have their roots in the fraught colonial and/or apartheid past.

Other writers, such as Fiona Scorgie (2002), have noted the revitalization of 'traditional' practices, including virginity testing (ukuhlolwa kwezintombi) for young women and girls, in an attempt to respond to the epidemic in ways that are meaningful to rural communities - a practice that has also re-emerged in some areas of Okhahlamba. With respect to virginity testing, it was one of the few overt, local and public responses to the disease, yet in its exclusive focus on young girls, it removed responsibility for sexual conduct from men and boys. Responsibility was then placed on the shoulders of young girls, whose power to control sexual situations was often limited (ibid: 67; Leclerc-Madlala 2000: 3). Local responses to the epidemic, therefore, took on gendered fault-lines within common understandings of sexuality, gender and morality (Henderson, 2004: 50-5I; Scorgie, 2002: 67 and Farmer, I993). It was widely upheld that wives, the 'grinding stones' (imbokodo nesisekelo) of homesteads, were morally responsible for their consolidation and were expected to remain 'fixed points' in the peripatetic lives of migrants. ${ }^{16}$ It was sometimes claimed that the home was marked sexually by refusing to use condoms with one's wife and by using them instead with other lovers. Local 'solutions' to the epidemic, it would appear, were underlain by the naturalization of patriarchal threads within social life.

In conversation, Ntuthuko and other healers in Okhahlamba often appealed for the reinstatement of 'customary' sexual and courting repertoires, for example, non-penetrative sex, 'thigh sex' (ukusoma), before marriage. The suspension of complex social courting procedures that were still employed in some of the more 'traditional' areas in Okhahlamba was also lamented. Nonhlanhla, for example, outlined for me all the theoretically appropriate stages that were operative in the past, which would lead up to a girl choosing a lover (ukuqoma). At each point in the process, a young girl was guided by an older girl, a leader (inkehli), and the point was marked on the bodies of young men and girls by the beads 
they wore and by public acknowledgement of some sort. ${ }^{17}$ Nonhlanhla and Ntuthuko lamented that such practices were not universally upheld and were no longer enforceable.

In the complex interweaving of pasts, oppressions, identities and the ambivalent intermingling of institutions associated with modernity and those associated with custom, we begin to see a mercurial dis-ease within the social web of understandings in Okhahlamba, as well as, perhaps, the multiple ways in which individuals associated themselves with both 'Zulu' medicine and bio-medicine. ${ }^{\mathrm{I}}{ }^{\mathrm{I}}$ In what I have written above, I have intimated insecurities within the worlds of custom, as well as the distrust with which institutions associated with the white man and the new state were viewed. I now return to conversations with Ntuthuko and Nonhlanhla in order to explore apocalyptic visions of the present, given the perceived failure of local repertoires in combating the epidemic, and, in contradistinction, the hope that anti-retroviral therapies have brought, particularly in the experience of Nonhlanhla, who saw the results of medication in the lives of some of her patients. Both healers insisted on the particularity of the times, times when the gamut of responses across the society as a whole seemed inadequate. Both acknowledged that the healing frameworks of diviners and herbalists, as well as those of medical doctors, had not provided any cure for HIV and AIDS. Bio-medicine had, however, provided medication that could suppress the effects of the virus and that could prolong the lives of AIDS sufferers.

\section{AIDS as apocalyptic sign}

In exploring the particularity of the times, Ntuthuko said:

We grew up as people speaking about the days in which we now find ourselves - that there would be fire, lots of water and incurable diseases. The earth would come to an end [selibhubha] at this time. The nation has come to that pass [ithuba, literally "opportunity"]. We cannot take it anywhere. What we should do is to pray to God because we are living on "extra time" [English]. Do you not see that right now the time for living has finished? There is no time for living. It is a thing that is no longer here. The time that is here now is for death; we are dying a great deal; we are coming to an end. [Isikhathi esikhona manje esokufa sife kakhulu siphele.]

The shades speak of the illness. It is now our way of life. The time has come that was predicted. It is not that in that home, the home of an inyanga, there is no death and that there, in the home of a doctor who carries needles and strong medicines there is no death. Everyone is dying. The time has come. I myself saw fires, people being burnt, chained; burnt with tyres. ${ }^{\text {I9 I saw the }}$ conflict of "Black Power". ${ }^{20}$ We were oppressed by the Boers. ${ }^{21}$ Change came [kwafika uguquko]. The ANC and Inkatha started to fight one another. People died. Things happened. Here are the dams that were spoken about. ${ }^{22}$ 
People dying, I saw them with my own eyes. People die now, killed by this illness that is here, and it was spoken about when I grew up, that in the future there would be many illnesses. I saw that. Who said that? It was God and the Bible. It was known that at this time there would be many diseases. Here they are! You cannot prevent them. (Interview, 30 August 2005)

In his speech, Ntuthuko wove together a catalogue of disasters that have emerged in the turbulence of South African history, linking these on one level with dis-ease of a social and physical nature, and on another level, with the metaphysical apocalyptic predictions of the Bible. It is precisely in the dense allusions contained in the above speech that my attempt to show the inextricable intertwining of illness and social relations begins to cohere.

Despite the fact that Nonhlanhla found hope in ARVs through witnessing their positive effects, she still attributed human agency to the creation of the virus. In doing so, she held out a transcendent place beyond the world, where the person responsible for the virus would be shamed. Implicit in her conversation was the conviction that the creator of the virus belonged to the 'expert' world of scientific invention. She was fully aware of the malevolent potential of 'western' science. What she said had meaning in relation to the insertion of science within a politically fraught social field, as has been alluded to in the previous section of the chapter.

You know, the person who came up with AIDS sat down and planned carefully how it was going to wipe out the nation. He correctly identified sex as a "good tool". Eventually they made it. People do not trust the safe sex you are talking about. The very same people who are destroying them are those who are manufacturing condoms. But you see, that person who made AIDS - we are all going to go to Heaven. He might be an expert, but he is going to die one day. He will meet the people he is killing with AIDS. He will meet them in their numbers, showing their anger and strength. God does not spread AIDS. It is not he. He created you and loves you. This is somebody's creation. It is politics. It came with politics, that's a fact. Before the elections, there was no AIDS and after voting AIDS came. We have grandmothers, very old. They did not die. Our children die at the age of thirteen and fourteen years now.

Imagine just beginning to have sex and then you are gone! It is very difficult. It is hard. God will save us. Blacks were created by God. We are all his creation. He loves us. That is why he made us to decorate his earth [sihlobise umhlaba wakhe]. But now we are mistreated and killed in this way like flies that are sprayed with Doom [the brand name of a local insecticide]. (Interview, 27 May 2003)

Nonhlanhla's vision of a transcendent place was one in which the boundaries between 'white' and 'black' worlds were, in her view, appropriately 
upheld. It was a world in which the threads of continuity and responsibility between the living and the dead were insisted upon, a world in which the maintenance of proper social relations was upheld:

Heaven is still there. It is the new world to which we are going. We go to live there in large numbers, living as families, families, families. If you have done wrong, if you have been a sinner, you will not join your family. You were not good. But people are confused. They tell themselves that when they die they will go up above to heaven, and that when they get there they will find a white person [Phumzile and I laughed], that a white person wearing white robes and carrying a Bible who will say, "Come in" or, "Do not come in". Instead, you will go to your family. You will find your father and mother, and your grandfathers. You will find those whom you have called "demons", those whom you have called all sorts of names. Those are the people you will find in the end.

But do not be misled that you are going to a house that glitters. No, you will find your familiar home. There is your family. If you did good things [while still alive], when you appear they will say, "Here is iNkosazane" [term of respect for an unmarried woman, referring to myself], and they will be happy. But if you did bad things they will say, "Tell her to stand there". You stand there, far away, and you cannot come closer no matter how much you might wish to.

Because you did bad things, leaving them [the ancestral shades] hungry while still walking on the earth, how will you go to them? You see, they eat there. When we burn impepho, giving out smoke we are making food for them. They eat. You [the excluded shade] can see them [the other shades] eating and you are hungry. You can see them drinking and you are thirsty. You do not know how to get [food and water]. You wait until someone feels sorry for you, takes a bone and throws it in your direction so that it makes a clattering sound. And you will run for it quickly, because you did bad things [while still alive]. (Interview, I5 June 2004)

\section{No cure for HIV and AIDS}

Both Ntuthuko and Nonhlanhla insisted that neither indigenous medicine nor bio-medicine had come up with a cure for HIV and AIDS. They had both undergone training in ARV therapy and the illness from a biomedical point of view. Witnessing the effects of ARVs gave hope, at least to Nonhlanhla, who saw the improvement in the lives of many of her patients who had begun treatment. The evocative image she used to describe the results of taking ARVs was of people returning to their bodies (wabura emzimbeni), as if during the radical course of the illness their 'proper' bodies had been put aside. She stressed the importance of adherence, saying that if you left the pills you would have committed a sin. You would have built a treacherous donga in which the virus could rise 
up and increase. (Uma uwayeka wakha udonga lokuthi igciwane liphakame.) Of the effects of ARVs, she said:

Really ARVs reawaken people. [Ngempela amaARVS ayabavusa abantu.] I remember that I told you I had a person who was very sick in a way that cannot be described. I told you that I did not know what I could do. He now really has the hair of a person. [Manje usenezinwele zangempela zomuntu.] One can now endure looking at his face [literally, "His face can now be looked at", "Ebusweni useyabhekeka"]. He is stout [ukhuluphele]. When he walks on foot he is unable to walk slowly, he goes at a fast pace [literally, "he stabs with doves", ahlabe ngejubane]. He says it is as if he is dreaming of himself [as he used to be before the illness] because of the good life he is now living. (Interview, I5 November 2005)

Ntuthuko insisted that ARVs were a special case and could not be taken with amakhambi ensintu. In this instance, bio-medicines and the materia of Zulu medicine could not complement one another:

The different medicines do not connect even a little, because among traditional medicines there are none that have emerged and been tested that may claim they are especially for this illness. If you want [to become healthier], to live through eating these pills, you must stand together with the pills and not mix, because mixing is a problem. This is because the pills perform their own work. They have their own scale [anesikali sawo]. In Zulu medicine, there is not yet any medicine that is directed in a straight line at this illness. These containers of herbal medicine [izigubhu] that people buy make no difference. After a person has begun the pills, having drunk izigubhu, he will see then that help does not lie there. However, some people when they start ARVS return to izigubhu. In the end, if he happens to die the family will say he was killed by the pills. They say, "If you eat these pills you will die", whereas this shows their distrust [ukungathembi]. When you use ARVs, stick to them. I have seen many people getting well. I am speaking about something that you can hold, that you can touch, about people who were dying. We took them to get help. They are now living extremely well with their families [on the pills]. (Interview, I5 November 2005)

Nonhlanhla's own relationship with HIV and AIDS no longer seemed that threatening:

Even if it grows in me today I no longer care about it. I am not anxious, because AIDS is like a young boy in relation to me and I am a man in relation to it. [Ngoba iAIDS isiwumfana kimi mina sengiyindoda kuyo.] (Interview, I5 November 2005)

Accepting bio-medicine in relation to HIV and AIDS as a special case in which medicine from different kinds of healing frameworks could be 
combined, did not imply that Nonhlanhla had abandoned her calling as a diviner and healer, together with its wider social field of application:

I will not leave the work of the ancestral shades behind, because my ability to heal did not just appear [from nowhere] - my saying that I am an isangoma. I was given a gift, because it was granted to me. That is to say, those who granted this to me are the ones who will come and take it away from me. Because they have not taken away this gift, I treat illnesses not connected with lesisifo. It is only this illness that I do not treat. If a person consults me whose body is diminished and who is ill in many ways I ask them first to go to test their blood at the clinic. If they return, telling me that they have lesisifo, I do not lie to them and say that I can cure them.

Even those who carry me [the ancestral shades] have told me about the new illness. They say today is not like yesterday [namhlanje akusafani nayizolo]. They explain to me that the illness that is here today is not that of the past; it is another kind of illness. [Isifo esesikhona namhlanje akusiso lesiya esakudala sekungesiny' isifo.] The old people have come to explain. They say that I should listen and understand that the death of today is not the same as the death of yesterday. I saw my grandmother who explained that the illness that is here is not the illness of the past. It is a new illness. I even told her, "Grandmother, I would be happy if I could in the end understand the [illness] of today". (Interview, I5 November 2005)

\section{Conclusion}

Walter Benjamin (I977: 259-260) reflects on Klee's painting, the Angelus Novus, suggesting that the image depicts the angel of history with its back to the future, being driven inexorably forwards, although facing the debris of the past. It is an interpretation of history that implies the violent eruption of the past into the present and perhaps the ways in which the past may come to haunt the present. It implies, in a way that Benjamin may not himself have intended, that fragments of the past that come to haunt us may be juxtaposed together and interpreted in various ways, as has been born out in much of what has been written above.

Although South Africa has been a constitutional democracy since I994, this has not produced economic and social freedoms for most of its people, including many rural dwellers. Racial divisions remain within the geographies and practices of everyday life, and the disparities between rich and poor have in some cases been exacerbated, even though more Africans have entered the middle class. Rural dwellers' experience of public institutions demonstrates that these do not serve people appropriately. Widespread suspicion of public institutions is something that despite a change in government has continued into the present. It is in arduous interactions with such institutions that people have often received inadequate service, and have instead been exposed to inexplicable 
delays and in some instances, corruption and force. When the date for beginning the national ARV rollout was postponed, Nonhlanhla, for example, expressed her disappointment by saying that it was as if the state had placed a wooden bar across an entrance (umgoqo emnyango) that had already been revealed to people. (Interview, 22 September 2003).

David Atwell (2005: 7) argues that within a context of liberal capitalism, the challenge is to '[reconnect] the nation-state with a culture of rights and participatory democracy', and most pertinently, of 'localising and actualising what have become compromised universal principles'. ${ }^{23}$

In contrast, Jean and John Comaroff (2004: 6) have identified 'a counter-politics of ethnic assertion against the jurisdiction of the state', that, in their opinion, cannot be happily accommodated within the South African Bill of Rights. They go on to suggest that different notions of sovereignty are circulating in South African society, one being 'the sovereignty of African traditional governance and the kingdom of custom, in which ethnic subjects claim and are claimed by [a] species of authority [other than that of a liberal modernist state]'. Different kinds of sovereignty have led to conflicts in the public domain with regard to 'occult beliefs, corporal punishment, landholding, initiation ritual, inheritance and succession', and, I would add, virginity testing.

With respect to both indigenous and bio-medical healing frameworks in Okhahlamba, I have tried to show how, just as they may demonstrate difference, they are also intertwined, and that innovative ways may be found to accommodate them. Such complexities lie at the heart of modernity. And, as has been suggested in the chapter, forms of possession and dispossession that comprise modernity are played out within individual bodies and across social fields. 


\title{
5 Love in a Time of Adversity
}

\author{
'Set me as a seal upon thine heart, as a seal upon thine arm: for love is as \\ strong as death' \\ The Bible, Song of Solomon 7: 6 \\ 'You are a beautiful person, Toloki. That is why I want you to teach me how \\ to live. \\ And how to forgive.' 'You are the one who will teach me, Noria' \\ Mda I997: I5I
}

This chapter narrates the love story of two HIV positive people, Ntombikayise Dladla and Olwethu Njabulo Bhengu. Depicting how they came to desire one another and how their courtship negotiated the discovery of the affliction they held in common, it suggests the implosive presence of HIV and AIDS within a relationship, and yet indicates how they upheld their wish to embrace life. Despite being ill, they insisted on the completion of drawn-out marriage negotiations. ${ }^{\mathrm{I}}$ Neither Ntombikayise nor Njabulo came from wealthy families. The completion of a marriage held the possibility of respected personhood in the face of poverty and illness, notwithstanding the sometimes repressive contours of marriage. ${ }^{2}$ They came to live life in an acute way, apprehending the closeness of death: an apprehension that marked a journey through fear, through an initial compulsion to allocate blame - at least on Ntombikayise's part - into a place of mutual respect and care.

Ntombikayise's and Njabulo's story is one in which illness and the building of a particular kind of union were inextricably intertwined. In facing their illness openly, and in appearing in public together to speak of it, they came to reshape, to some extent, commonly held ideas of masculinities and femininities. Ntombikayise's and Njabulo's story is atypical of an area where many men insisted, both conceptually and often in practice, on a differential standing between men and women in their negotiation of intimacy. ${ }^{3}$ I relate it, however, because it suggests ways in which partnerships may become stronger through adversity, rather than dissolve. It indicates an amplification of each person's sense of self over time that is reminiscent of Foucault's emergence of the ethical subject through care of the self: 'the self taking itself as a work to be accomplished' (Davidson 2005: I28, Foucault I986). It is a story that, although marking changes in each individual, demonstrates the importance of interdependence between people. It is a story of hope that needs to be told in a context in which so many have died, because in Ntombikhayise's and Njabulo's case, death is postponed and a future envisaged. 
It is important to insert desire, or more pertinently, Eros, into an exploration of the effects of HIV and AIDS within intimacy, as its disruptive and generative power in relation to sexual relations and the creation of wider worlds has largely been omitted from 'antiseptic' discourses on the mechanics of sex in the context of HIV and AIDS. ${ }^{4}$ In writing about HIV and how people are taught about prevention, for example, sexual life and how it is interwoven with various kinds of social relations is invariably flattened, so as to focus on the mechanics of a limited form of heterosexual sex. The discourse employed is medical and technical. People are told to 'use a condom' to avoid contracting the disease - a matter of adopting a rudimentary technique. Yet techniques that seem simple to promoters of prevention campaigns may profoundly disturb the way people have come to experience and understand intimacy, such as that within marriage. ${ }^{5}$ The way sexual life is embedded in how people imagine the fulfilment and unfolding of desires, holding, yet reaching out beyond the act of sex, is omitted.

The chapter explores the absence of literal fecundity in relation to the surprising fecundities of a certain kind of love in the context of HIV and AIDS. It therefore raises the tensions between social expectations of fertility in marriage and the potentially death-dealing effects of AIDS on fertility. Part One charts Ntombikayise's and Njabulo's relationship and their accommodation of the illness over time. It is an account of the care each offered the other. Part Two deals with publicly held and enduring metaphors of care in the process of gift exchange between their respective families in completing the marriage. An exploration of the symbolism of care, together with particular hierarchical and gendered inflections, is accomplished through an examination of the exchange of everyday objects used in the ongoing cleansing, nourishment and comportment of the body. Their naming and use are layered with allusions to the generative force of desire, sex and fecundity. Their formal exchange within a heightened ritual context suggests how objects may 'impress' various meanings upon those who have come to exchange them, making visible how forms of care emerge through the taking up of obligations held and formed within relationships between and within families, in this case, created through marriage. The latter social relationships include those between the living, and between the living and the dead. ${ }^{6}$ Ongoing attempts at the formation and repair of the above relationships create the social ground from which hoped-for generosities may spring. Yet folded in with generosities is the shadowy undertow of everyday life, the way norms create forms of exclusion and silence.

The sections of the chapter appear alongside one another in order to draw out the tension between personal intimacy and the immediate challenges of the ravages of illness, and a simultaneous search for social recognition through the symbolic staging of publicly held norms of care in rituals to do with marriage. The personal and the normative imply differing temporalities. The first is linked to the disorganization that ill- 
ness intermingled with desire create within social worlds. In the face of chronic illness and the imminent possibility of death, futures are foreshortened. The second temporality implies the projection of a long-term future, in which ongoing generation is seemingly unproblematic and where the continuity between generations is provided by the protection and generative powers of ancestral shades. Ntombikhayise's and Njabulo's story is one in which the two temporalities of necessity mingle, and where the projection of a hoped-for long-term future bears its own defiance and poignancy.

\section{Part one}

\section{Of meetings}

I came to know Ntombikayise, her mother, her daughter and others living in and around her mother's homestead over a three-year period. I also met Njabulo, Ntombikayise's husband, his mother, his daughter, his brother's wife and her two sons. On first meeting Ntombikayise, I learnt of her activities as a home-based carer, a position in which she volunteered to visit the ill in their homesteads and to assist patients in liaising with formal health institutions. ${ }^{7}$ I visited her mother, a diviner (isangoma), in her own homestead. Soon Ntombikayise confided her HIV positive status to Phumzile and myself.

When we visited her at her marital home, Ntombikayise began to speak of her great love for her husband and the complex marriage negotiations that had taken place between their respective families. We poured delightedly over a set of photographs depicting major exchanges of gifts, a church marriage with seven bridesmaids and seven groomsmen, and a reception in Ntombikayise's parents' home area. Other photographs depicted the subsequent ceremonies at Ntombikayise's husband's home, where proceedings included her father introducing the ancestral shades of his lineage to her new place of residence and informing them of her marriage into a new family.

At Ntombikayise's marital home, I learned that her sister-in-law had contracted AIDS, having lost her husband to the disease a year earlier. Ntombikayise soon formed a bond with her in which they freely discussed their illness. They kept knowledge of their illness from their mother-in-law for some time. I then met Njabulo, her husband, who during the course of the research was involved in construction work in distant towns. He was a founding member of a seasoned isicathamiya group, the Black Notes, made up of men in their forties and fifties who had performed in the Ladysmith area and in Durban for many years. ${ }^{8}$ Njabulo was delighted that I visited his wife and mother at his homestead, and it was not long before I began watching some of the group's performances. 
Through deepening of ties, Ntombikayise, Njabulo, Phumzile and I became firm friends, and the couple began to visit me at my home. I attended public forums in which they spoke of their relationship, of their discovery of the illness they held in common, and their ways of dealing with it. They were persuaded to do so at the prompting of a local nongovernmental organization (NGO), which was attempting to spread AIDS awareness amongst church-goers. It was at the latter meetings that I became particularly aware of Njabulo's respect for and graciousness towards his wife: qualities that were conveyed in his rich use of language. I was also privy to the couple's stated need to sometimes withdraw from public appearances. In particular, I was privileged to be singled out by Njabulo as the person, a relative 'outsider', with whom he felt at ease in speaking of his illness, even when the need to withdraw from public appearances arose.

Ntombikayise and Njabulo were the only couple I saw speaking in public of their HIV-positive status. It is from the above diverse sets of interactions with Ntombikayise's and her husband's families that I write an account of their 'love story'.

\section{Beginnings of love and negotiation for marriage}

At the age of nineteen, Ntombikayise Dladla became involved with a man for the first time. (Ukuqala kwami ukuhlangana nomuntu wesilisa.) Soon thereafter, 'great misfortune befell [her]' (Ngavelelwa yishwa elikhulu): She separated (sahlukana) from her lover after having given birth to a daughter, Nonhlanhla. Nine years later, and having become a practising charismatic Christian, she met Njabulo, the man she was to marry. As their courtship progressed, Ntombikayise found that she wanted to make love to Njabulo, and yet because of the strictures of her church, thought it best to persuade him to delay a sexual relationship until after they were married. The desire they had for one another, however, proved too strong. For Ntombikayise, abstinence became difficult because she claimed: 'I loved [Njabulo] in an astonishing way, my flesh troubling me greatly'. ('Ngangimthanda ngendlela emangalisayo. Inyama yayingihlupha.') Once she had formally accepted Njabulo as a lover, an agreement referred to in isiZulu as ukuqoma, Ntombikayise was impressed that when she met with him, ostensibly to have sex for the first time, they spent the night speaking at length about their backgrounds, their families, the places in which they had lived as children and what they wished for in their relationship. It was some time after the above meeting that Ntombikayise and Njabulo began 'the work of the mat' ('umsebenzi wocansi); that is, began having sexual relations.

To Ntombikayise's joy, early one morning in June 2000, approximately nine months after their first serious meeting, an umkhongi (marriage negotiator) ${ }^{9}$ arrived at her father's homestead. In accordance with local protocol, he spoke from outside the homestead, projecting his 
voice, 'asking respectfully for good relations [ukukhuleka], and good friendship [ubuhlobo obuhle]' with the Dladlas. He asked 'to build a fire [ukokhela umlilo]': a reference to both the potential creation of a new hearth for the couple, but also to the life-giving heat generated by sexual desire and its consummation. With the above forms of address, the $\mathrm{um}$ khongi asked to open marriage negotiations. Central to his visit was the promise, or 'announcement', of a red heifer from the Bhengus to the Dladlas, a beast that would form part of ilobolo, the bridewealth; a gift of cattle from the groom's family to the bride's father. ${ }^{\text {IO }}$ Ntombikayise suggested that when she heard the umkhongi 'asking for good relations through a heifer, a red beast with four legs', she 'was so happy [she] did not know where [the sun] rose or where it set' ('Ngangingazi nokuthi liphumaphi lishonaphi) (interview, 26 May 2004). Implicit within the announcement of a red heifer was the idea of its future fertility, in that once it had reached maturity it would produce calves. As there is metaphoric resonance between people and cattle in the context in which Ntombikayise and Njabulo lived, the announcement of the heifer pointed to hoped-for fertility in a wife.

Subsequent to the umkhongi's first appearance, a series of protracted marriage negotiations ensued in which bridewealth cattle were ultimately given by the Bhengus to the Dladlas, and in which household gifts and clothing were exchanged between the two families in cycles of gift-giving, the most prominent of which were the ceremonies of umembeso and umabo (see below). On the one hand, the bride's family made up a list of izicelo (requests) for gifts to be distributed amongst their relatives, and on the other hand, the bride collected gifts over time to reciprocate those given by the groom's family. It was the umkhongi who, in Ntombikayise's words, acted as a 'postman' in delivering lists of gifts requested from each family.

\section{The force of desire}

The powerful attraction between Ntombikayise and Njabulo is best captured in Ntombikayise's words. They show the strength and enlivening qualities of desire, the way in which heartfelt resolutions may be disrupted, propelling one into states of emotional and physical acuity, into passions, suffering and delight over which one may have little control. Into a field of heightened feeling, the loving curiosity to know more about the person with whom one is in love is evident. As she told her story, her voice soft with tenderness, Ntombikayise's eyes sparkled. She smiled shyly and laughed, her right hand coming to rest at times on her heart. Her vibrant presence showed how a reiteration of past events created a welling-up of feeling and of desire.

Ntombikayise's attitude in the telling is reminiscent of that which Julia Kristeva (1987: 3) has described as a crisis of love: an enlivening affliction accompanied by a vertigo of identity and of words in the person 
struck by love. Yet in that very affliction, the possibility of renewal resides. For Kristeva, love is a 'sudden revelation', a 'cataclysm' of which one speaks only after the fact. She asks whether the manifestations of love in an unsettled body, 'the body swept away, present in all its limbs ...: shaky voice, dry throat, starry eyes, flushed or clammy skin, throbbing heart' could be likened to symptoms of fear. And suggests that the onset of love manifests both 'the fear and the need of no longer being limited ... the fear of crossing and the desire to cross the boundaries of the self' (ibid: 6). Returning to Ntombikayise, of her own experience of love, she said:

[In I997] I met a man, Olwethu Njabulo Bhengu, ${ }^{\text {II }}$ next to the butchery in Ladysmith (the major district town). A woman from the church accompanied me. I was still very taken with the Gospel at that time.

When he met me, this young man said, "Sawubona sisi [I see you, sister]". I acknowledged him. Then this brother said [to my companion], "I want this sister to cook for me at my home, to cook for my mother" [Ngifuna losisi ayongiphekela ekhaya, ayophekela nomama - overtly an assertion of the wish to marry Ntombikayise, yet quite a formulaic phrase used in courtship]. ${ }^{\text {I2 }}$ He then passed by. But his passing by left an open wound in my heart. [Wabe esedlula, kepha ukudlula kwake kwasala kuyixhwele enhliziyoweni yami.] I said, "Oh, my people! I have seen this brother". It was as if I had been hit on the head [Ngashayisana ekhanda]. Because I was still devoted to God, I said, "God, you said according to your word that I must examine closely whether a person is coming in truth".

It went on and on like that [my feelings for this man], and in I998, I was crossing an intersection from the robot near Kentucky, the old one. ${ }^{\mathrm{I} 3} \mathrm{He}$ came from the other side next to the [taxi-]rank. We met in the middle of the road where we looked at each other. Neither of us spoke. The robot closed [turned red]. I returned to the side of the road and he also went back with me. When we were next to the robot he said, "Sisi, I have seen you before". I also said that I had seen him before. "Where have you seen me?" I pretended I did not know. He then asked, "Aren't you the child of $u B a b a$ [Father] Dladla, the pastor?" I said that I was. He said, "It was you whom I saw, and I told you that I want you to cook for my mother at home".

The trouble started. My heart started to jump, jump. [Yaqala inkathazo. Yabe isiqala-ke inhliziyo yagxuma gxuma.] I said, "Oh! Here is this young man again”. It went on throughout I998 and I999. And in September I999 I accepted him as my lover [ngamqoma]. ${ }^{\mathrm{I}}$

... I had to meet with this brother. I told him about the Gospel, that people should not sleep with one another until they were married. This brother said he wanted to take me then [to have sex]. I also had my doubts about waiting for the correct time to meet because this thing is not really there [ayikho phela lento, meaning the strictures of the church were not reasonable].

... When we met, I thought we would do a big piece of work [sizokwenza umsebenzi omkhulu, an allusive reference to making love]. But this brother 
wanted to hear all about my background, my beginnings, all of it [usafuna ukuzokuzwa imvelaphi yami yonke]. I had found an amazing brother. He is not a believer [a Christian]; he sings ingoma yobusuku [night song] ${ }^{15}$, and dances the songs [uzigidela izingoma]. When we met, he said, "My sister, you said you are a Christian and you want us to come together in marriage. Today I ask that each of us speak the truth. Where do you come from and where are you going?" Indeed we slept the whole night without doing anything [without having sex]. Some time after this meeting we began the-workof-the-mat [umsebenzi wocansi, sex]. (Interview, 26 May 2004)

\section{Ntombikayise's illness}

As written above, the impassioned beginnings of Ntombikayise's and Njabulo's relationship and discussions concerning what each of them wanted from it led to the onset of marriage negotiations between their families. In the midst of the negotiations, in July 2002, Ntombikayise and Njabulo discussed their longing for a child. Ntombikayise had difficulties in falling pregnant. ${ }^{16}$ She and Njabulo each had a child from a previous relationship. Ntombikayise's daughter, Nonhlanhla, lived with her up until Ntombikayise's marriage, remaining in Ntombikayise's parents' homestead thereafter. ${ }^{I 7}$ Njabulo's daughter, Sbo, remained in her father's homestead after his marriage. Given the existence of children from previous relationships, Njabulo's and Ntombikayise's inability to conceive in a relationship linked to marriage was particularly painful. As Ntombikayise described it, after having gone to a hospital to try to locate the problem, a doctor suggested that she 'clean out her womb' (it was not clear whether this was a reference to a dilation and curretage (DNC) or to medication for an infection). She was also persuaded to have an HIV test, and it was then that she came to learn for the first time that she was HIV positive.

On hearing the news, Ntombikayise was greatly distressed. Her feelings were compounded by the fact that she had already lost a brother and a sister to the disease. As a home-based carer, she had unsuccessfully tried to persuade her brother to go to the clinic for treatment. Her brother had decided not to take any medication. ${ }^{\text {I8 }}$

When Ntombikayise first heard of her HIV status, the urge to commit suicide was strong. In a diminished state, she questioned her future plans to get married to Njabulo:

I saw it [the disease] as this thing eating me up. It wanted me to take something to kill myself. [Ngabona ukuthi lento iyangidla. Ifuna ukuthi ngithathe into ethize ngizibulale.] ... I said that this thing could not be cured. It is not curable. It was only that I had to wait for death. [Ngathi mina lento ayilapheki ayelashwa. Kusho ukuthi nje kufanele ngilindele ukufa.]

The reason I lost weight was not because of my being ill. I lost weight because of my heart. [Ngehla nasemzimbeni. Ngangingehliswa ukuthi ngiyagula 
ngangehliswa yinhliziyo.] I told my mother. She was worried, and then told my father. It was bad at home. I then asked them how it would be if we asked the kwaBhengu people [literally, the people from the place of the Bhengus] to wait. They should not continue with the negotiations because I didn't know what kind of a life we were going to lead. My mother said that she had an idea that I should tell my umkhwenyana [betrothed] that I had gone and found that I had this. At first I doubted whether I should tell him. (Interview, 26 May 2004)

Her words convey the idea of being taken over by the virus, and an apprehension of diminishing power within herself. She envisaged the disease as striking a blow, not only to her body, but also to her spirit, and indeed casting a shadow over all her future plans.

I then sought a way to tell this brother that we should leave behind the story of our wedding. [Ngase ngifuna indlela yokuthi ngitshele lobhuti ukuthi sihlukane nendaba yomshado.] I could not find a way because by that time he had asked for me, and had given ilobolo [bridewealth], but I had not yet been dressed [given the clothes] to prepare me as a bride. [Ngangingasayiboni indlela ngoba ngalesosikhathi wayesecelile walobola kodwa ngangingakambeswa ngilungiselela ukuba umakoti.] In my heart I told myself that when I met him in town, I would refuse him. I wanted to tell him that I wanted him to separate from me because he had poured this illness into me [usengithelele ngalesifo]. (Ntombikayise and Njabulo speaking at an AIDS education workshop, Busingatha, 27 July 2005)

Rather than succumbing to the disease's 'promptings' 'to take something to kill [herself]', Ntombikayise visited a clinic to seek medical advice, having been persuaded to do so by her youngest brother. Despite her knowledge as a home-based carer, it was only with her brother's support and insistence that medication would help her and that she should not give up that she became more hopeful. Ntombikayise was surprised and mollified by Njabulo's response when she eventually told him of her HIV-positive status. She had initially wanted to blame him in order to deflect any blame or rejection he might have directed towards her. Her anger is forcefully captured in her description of his having 'poured the illness into [her]'. The mixing of sexual fluids, that under optimal conditions suggests a mingling with another in which ecstatic dissolution of boundaries is welcomed (at least according to Kristeva), now takes on an opposing quality - one that is viscerally horrifying and life-threatening. ${ }^{\text {I9 }}$

In Okhahlamba, an optimal commingling of fluids in heterosexual sex is understood in particular ways. For many, the 'water of a man', semen, is perceived as the substance that moulds a child in its mother's womb through the work of a father's ancestral shades (see Bergland, I976: 94, II7). Female sexual fluids are often viewed negatively, and are, in some cases, controlled through the practice of 'dry sex', where women use sub- 
stances to absorb vaginal moisture and to 'tighten' the vaginal canal. ${ }^{20}$ The blood of a woman, however - that which is discarded monthly when not pregnant - is brought to the place of conception by a woman's shades, and is understood as providing the sustenance required in the formation of a child. When combined, 'water' and 'blood' are construed as positive, not only most obviously in being brought together to create a child, but also for the people engaged in an intermingling of substances. Because of its association with death, the presence of HIV leads to a violent overturning of such connotations. ${ }^{2 \mathrm{I}}$

\section{Suspension of blame}

When Ntombikayise first told Njabulo, he sat quietly and then suggested that if she had the illness, he most probably had it also. Neither Ntombikayise nor Njabulo showed any outward signs of illness, yet Njabulo had had intermittent periods of ill-health that he had successfully treated with herbal medicines. Njabulo's maturity must be taken into account in understanding his response to Ntombikayise. He was of an age where he wished to create a marriage in order to build a homestead. Becoming a respected head of a homestead ideally demanded dignity, and the careful ability to weigh up circumstances. Njabulo stated that neither of them was young any more. He was in his early forties and Ntombikayise in her mid-thirties. It was therefore not possible to say for certain where the illness had come from, as they had both had previous lovers. Njabulo was intimating indirectly that he, too, might be HIV-positive, although he had not taken a test. He affirmed that it was not possible to precisely allocate blame. Even if they both had the disease, it did not mean that they should abandon their plans to get married. They would get married and live the best life they could, 'as they were'. In Ntombikayise's words, spoken at a meeting to educate church-goers, she said:

He asked me how I had experienced the hospital. I said that I had gone well, but that the biggest problem was that I had ingculaza [the virus]. My intention was that I wanted to point at him [Inhloso yami ngangifuna ukuthi ngiyikhombe kuye], blame him for the illness. He sat quietly and then said, "If you have ingculaza it means then that I have it too". I thought that he would say that he had got ingculaza from me and that we should leave things. He did not tell that kind of story. He put it behind him. I asked him what we were supposed to do. He said I should continue to go along with the treatment [Ntombikayise was taking Bactrim to help prevent various opportunistic infections], and he said he would also go to test his blood. I said in my heart, "He is not leaving me, even though I thought we would part, and I would die". He did not go there. (Ntombikayise and Njabulo speaking at an AIDS education workshop, Busingatha, 27 July 2005) 22 
In Ntombikayise's narrative, fears were related not only to the possibility of physical death, but also the death of her social bond with Njabulo, and the heartfelt emotions with which she had invested her wish to be married to him. The prospect of physical death was interwoven with the excruciating pain of the possible death of intimacy. Neither can the two types of death be easily separated. Her initial horror was partially informed by her knowledge of the ways AIDS destroys ties of intimacy and relationship.

At the same meeting, at which Ntombikayise and Njabulo spoke to a group of church-goers, Njabulo was asked by members of the audience why Ntombikayise had not been blamed for the illness, as was the experience of many daughters-in-law in a patrilineal context in which they left their own people to marry 'strangers'. ${ }^{23}$ In his speech, Njabulo emphasized that he had never blamed her. Approximately three months before their wedding, in December 2003, Njabulo became increasingly ill. He developed suppurating sores all over his body and could no longer work. Njabulo linked Ntombikayise's blamelessness for the disease to his association of moral goodness with the institution of marriage. Here, blamelessness was associated with what was regarded as socially life-giving and admirable, as in Ntombikayise's case, above. Consequently, Njabulo suggested that the members of his household, who came to know of their HIV positive status after the marriage, tended to blame previous girlfriends for the illness:

In the big home [referring to his parents' home] they took it [the illness] as a death I had received in certain ways. [Ekhaya elikhulu bakuthatha ngokuthi ukufa nje ngakuthola ngendlela ezithize.] My bride, I insisted, had not yet arrived at my home. It was not appropriate [to blame her for the illness]. Rather they said [the people of my home], "These things [referring to girlfriends] that used to come in and out of this home, perhaps it is them?" [Kodwa bathi, "Lezinto (izintombi) ezazilibe zingena ziphuma layikhaya, mhlambe yizo?"] (Njabulo speaking at an AIDS education workshop, Busingatha, 27 July 2005)

For all Njabulo's generosity towards Ntombikayise, his statement deflects blame for the illness to other women, ${ }^{24}$ especially women who do not share the status of wife, and who are referred to disparagingly as 'things'.

\section{Completing a marriage}

Ntombikayise and Njabulo continued with their marriage plans. It was only in January 2004, after the marriage had been completed, that Njabulo eventually took an HIV test. Before his test, on the 27th of February 2002, Njabulo accompanied Ntombikayise's father and youngest brother to see ten ilobolo cattle, a definite indication that he was committed to 
completing the marriage. In July of that year, the cattle were transferred to the Dladlas. Although eleven cattle had been requested as ilobolo by Ntombikayise's father, one was withheld because Ntombikayise had given birth to a child in a previous relationship. ${ }^{25}$

On the 9th of October, 2002, the groom's family dressed Ntombikayise in the appropriate clothes of a bride (ukwembeswa). She received three sets of new clothes: two pinafores that reached the ground and a shorter red suit. The long dresses would be worn as the appropriate dress for a new bride. She was given a shawl and several headscarves with which to shield herself from the gaze of her in-laws. A particular form of dress whilst in her husband's homestead would become part of a series of respectful avoidances that she would enact in relation to her in-laws. The latter would include linguistic avoidance of words that rhymed with her husband's name and the names of older men in her husband's homestead. She would also no longer refer to Njabulo and his male relatives by name, but in the case of her husband, would call him 'father of Sbo', after the name of his child. ${ }^{26}$ The red outfit was for her to wear on trips to town, or to work. The groom and his umkhongi were also given complete sets of clothing by Ntombikayise's family. The latter gifts were part of the ceremony, umembeso, to which the groom brought a large number of gifts for the abakhwekazi (women from Njabulo's family-in-law).

Ntombikayise and Njabulo enacted the final ritual components of their marriage on the 2oth and the 2Ist of December 2003. They had a lavish church wedding in Ntombikayise's home area on the first day, and were married ebaleni, referring to a 'traditional' wedding in the yard and cattle kraal of her husband's people, the Bhengus, on the second day. In the second ceremony, Ntombikayise was introduced to her husband's ancestors. Her father, calling out the praises of the Dladlas, also introduced Ntombikayise's ancestors to her husband's homestead, informing them of her marriage at 'the place of the Bhengus'. The introduction was accomplished through a present to his daughter of the inkomo yomgano, the marriage beast, a beast from her natal home. Like the animal announced by the umkhongi at the beginning of marriage negotiations, the marriage beast was a heifer. ${ }^{27}$ It was on the same day that Ntombikayise distributed gifts to the abalingani (the groom's people) in the ceremony of umabo.

The church wedding took place in a hall in Thintwa, the mountainous area in which Ntombikayise had been born. Over 200 guests attended. The couple were accompanied by seven groomsmen and seven bridesmaids dressed in suits and satins. Ntombikayise wore a white wedding gown and veil; Njabulo, a blue suit with a Chinese collar. The wedding ceremony was conducted by a priest from Ntombikayise's church. The couple made vows to one another, exchanged rings, and signed a marriage register. The formal marriage was followed by a reception in the same hall with speeches given by both Njabulo and Ntombikayise, de- 
scribing how they had met and fallen in love. They did not refer to their HIV positive status in their speeches.

\section{Njabulo's illness and the pursuit of healing}

Three months prior to and during his wedding, Njabulo had been extremely ill. Consequently, Ntombikayise held him upright for part of the ceremony at Thintwa. Before the wedding, she had nursed him, bathing the suppurations covering his body. As she described it:

We were married on the 2oth of December 2003. From August of the same year, before we got married, he was sick. He was afflicted with boils [literally carried by boils, amathumba]. Right up until the day our marriage came, he was ill, sleeping down on the ground. He no longer worked. I asked what we could do. The day of our marriage steadily approached; he was a person who could only lie down. Yet he had offered himself to me, I had offered myself to him [Ngokuthi manje yena uzinikele kimi. Nami ngizinikele kuye]. The time came for the wedding. On the I9th of December 2003, the wedding began [literally "entered", referring the arrival of the groom's party]. On the 2oth we got married. When our wedding day came, I held him [up]. He told me to hold him with strength because if I had not done so he would have fallen, only to be hit by the ground. I saw that my groom was going [dying]. On the 2oth we got married in the church. On the 2Ist we married at the groom's home. Our wedding finished. On the afternoon after the marriage I came to see that this person was extremely ill, he was ill in the way a person is ill who is about to go, to die. (Ntombikayise and Njabulo speaking at an AIDS education workshop, Busingatha, 27 July 2005)

Njabulo had always treated his own ill-health with herbal medicines purchased from a particular inyanga (herbalist). Like many people in Okhahlamba, he associated hospitals with death and disrespectful treatment on the part of nurses. After the wedding, Njabulo and Ntombikayise were left without financial resources, due to the accumulated costs of the marriage. There was no longer any money to buy herbal remedies, or even food. In the week after the wedding, Ntombikayise despaired that her husband would die. As a person of the church, she began to pray, a course of action that led to an unexpected series of events. In her own words, and speaking in a public meeting at which both Ntombikayise and Njabulo were present, she said:

On Tuesday, during the first week of my marriage, I saw during the night that this person [Njabulo] was dying. He said I should take him from the bed, because he was sick and dying. I said, "Oh my Lord" to myself, "let me pray". I begged [ngikhuleke]. "This thing is nothing", I said to myself. "Let me take the Bible and begin by reading”. When I opened it, R200 [\$33] fell out. We did not have money; we had nothing [because of the wedding expenses]. 
He has an inyanga whom he used to visit from a place that I will not mention here. ${ }^{28}$ That inyanga of his pulled death so it would ease off [Leyonyanga yakhe yathi ukudonsa ukufa kwathi ukuthi gozololo]. When I looked I saw, "My! Here is money". I said, "Here is money, Father of Sbo". The prayer stopped. Everything stopped [laughter].

"Hawu! Nansi imali! Here is money!" He too woke up. He said, "Where is it?" I said, "Here it is, let us count". We found that it was enough money to go enyangeni [to the place of the healer]. Because when you scoop medicine that is smoked and licked from the palm of the hand [umuthi wokuncinda], just a small thing equal to the size of a finger is $\mathrm{R}_{50}$ [\$8], a small thing. We did not have money for food, but we thought that his younger brother should take him to an inyanga. That same evening I went to ask his brother to help to take Sbo's father early in the morning to an inyanga. I told him I did not have petrol. ${ }^{29}$ The money was only enough for the medicine of an inyanga. He said there was no problem [literally, no stories, akunandaba]. The younger brother got up in the morning and rushed him to the inyanga. He returned extremely ill. The medicine was here. We saw that it no longer worked. My spirit became depressed, because the medicine was not working and that had been the last of my money.

It came to me that I was a home-based carer. I said, "Now, the thing that we will do, father [ $b a b a$, referring to her husband], I ask that tomorrow we wake up so that you can go to the clinic". He replied that it was a place he would not go to. He said that he was extremely ill and asked what help the clinic would give him. I said that the clinic would help him a lot. Perhaps we would get a letter to transfer him to a hospital. He said he was not going to the hospital. I said to him, "Then eat this medicine!" When I counted all the bottles full of medicine in the house that had not helped him, I said, "Go to the clinic. When you return from the clinic you can continue with your medicines". He said he was not going to the clinic because they would send him to the hospital and when he arrived there he would die. I said I would not be stubborn with him [meaning she would no longer speak with him]. I spoke with his younger brother and suggested we take him to the clinic the following morning. "The stories of izinyanga [herbalists] are finished. The money has finished, and we are now rushing to the place where it is free [the clinic; isiphelile indaba yezinyanga. Imali iphelile. Sesijahe kwamahala manje]. We are now going to the free clinic". When we arrived at the clinic, I myself did everything, keeping a place in line to register so that we would get a card because I knew he did not want anything [he did not want to be there]. He stayed in the car. When the queue came near to his turn, I fetched him from the car. He went in to see the nurse. When we arrived in front of the nurse she saw that boils, amathumba covered his body. She sent him to hospital. Indeed, the nurse wrote a letter to transfer him to the hospital. It was in the hospital the we really got help. After that I counselled him by asking if he remembered that I was positive. He said that he remembered this very well. I asked, "How about you going to take blood so that you can see the cause of 
these boils?" He listened. His blood was taken. He returned back [to the hospital] and found that he was positive.

Afterwards, everything went smoothly because I had been his only support, his prop, his assistant [ngiwusekela wakhe]. Then the programme of CD4 count came. His was very, very low [70]. Mine was high [750]. He then learnt about the medicine, umshanguzo, the ARVs. He then began taking the pills. This is where I saw that if you listen to one another, if you understand and communicate with one another and listen to a person there is hope, because with him I am able to live in a large way. Again, my life is continuing very well with him. Uma nizwana nomuntu nilalelana likhona ithemba ngoba ngaye ngaphila khakhulu futhi impilo yami isaqhubeka kakhulu ngaye. (Ntombikayise and Njabulo speaking at an AIDS education workshop, Busingatha, 27 July 2005)

Ntombikayise's account charts the way in which she respected her husband's choice of medicine and at a point of extremis, tried to ease his inclusion into settings where biomedical treatment could be sought. She insisted on his going to a clinic when herbal medicines no longer were effective. She used all her powers to try to persuade Njabulo to try another way. And in the end, when persuasion failed, she found means of getting him to a clinic with his brother's help. Her words suggest many things: her refusal to give up, the importance of sharing fears, the uneasy coexistence of different repertoires of care, and yet the ways in which they may be used in combination, in oscillation, or sequentially.

\section{Courage in the face of death}

When Ntombikayise had completed her account of her relationship with Njabulo at an open public meeting in which she had told the above story, it was his turn to speak:

The mother has beaten strongly [meaning that she spoke in an admirable and inspiring way]. Now I will beat a little bit, I will speak a little. [Umama useshaye kakhulu. Manje mina sengi zoshaya kancane.] This is because I see that she is jealous [a joke and a compliment implying that Njabulo did not want to outshine Ntombikayise in his speech]. It is as she has explained it. I have seen that the heads of the homesteads have been digging [graves, abanumzane bayagubha]. I was blown here and there, I was weak. My flesh was no longer here. My trousers, I folded them over [at the waist]. [Ngase ngiphephuka. Izinyama sezingasekho. Ibhulukwe ngase ngiliphinda.] When I walked, looking at myself, I saw that it was finished with me [... sekuphelile ngami]. It was found that the mother, with whom I am married, has patience. She has a liver. [She is truly courageous.] I was covered with suppurating sores all over my body. I was burned, truly burned. The mother said that I should go and check my blood. I went to check. I went back to collect the results. They said I had ingculaza, the virus [HIV]. They said I was sup- 
posed to go to the CDC [Communicable Diseases Clinic] so that I could get pills. I then learnt about the pills. I studied until I received them. I am now eating the medicine [umshanguzo, ARVs].

Eating the pills has helped me, because in my life I feel that I am now well. I have life again. The courage of Ntombi helped me, because if she had been a light person without courage, it would have been clear. [I would have died]. However, it happened that a child of a person said, "No, wherever you die, I will be there also". [... umntwana womuntu uthi, "Cha lapho ufa khona ngizoba lapho". $]^{30}$ (Ntombikayise and Njabulo speaking at an AIDS education workshop, Busingatha, 27 July 2005)

Njabulo's words were a poetic and loving testament to his wife, Ntombikayise, suggesting that through her patience and courage, both were able not only to survive, but also to expand the ways in which they lived.

Levinas (1989 [1987]: 39-42) writes instructively of suffering and the approach of death in ways that resonate with Ntombikayise's and Njabulo's journey. He draws a distinction: 'While in moral pain, one can preserve an attitude of dignity and compunction, and consequently already be free; physical suffering in all its degrees entails the impossibility of detaching oneself from the instant of existence' (ibid: 39). In suffering there is an 'absence of all refuge ... The whole acuity of suffering lies in this impossibility of retreat. It is the fact of being backed up against life and being' (ibid: 40). The latter quotations give an indication of how Njabulo may have suffered corporeally when most ill, as well as the way in which the approach of death lay within his suffering.

For Levinas, it is out of the realm of human possibilities to meet one's death. Death is not something that can be assumed, but rather comes upon one. Even on the brink of death, if a person is still able to inhabit the present moment, what Levinas describes as 'the now', she remains in the realm of possibilities. For Levinas, death cancels out awareness. He argues that one is not present at the moment of death. Death is the end of heroism, because it catches a person unawares. ${ }^{3 \mathrm{I}}$ Thus death marks the limits of the human, and is essentially unknowable. With death's arrival, one is 'enchained', 'overwhelmed', and 'in some way passive'. However, prior to death, there is always a last chance. For Levinas, it is the last chance that the hero seizes, and not death. 'The hero is the one who always glimpses a last chance, the one who obstinately finds chances' (ibid: 42).

If we consider Njabulo's suffering prior to, during, and after his wedding, he himself felt the closeness of death, and his suffering constituted the inescapable experience of being 'backed up against life' (ibid: 42). Through the diminution of his powers, his life was being 'encroached' upon. The possibilities of his marriage and the future it implied were being 'overwhelmed'. Ntombikayise and Njabulo's relationship is marked by heroism, as conceived of by Levinas, in that both obstinately sought a 'last chance' in sensing the approach of death. Even when Nja- 
bulo asked to be removed from their bed, to be placed on the floor in readiness for death, Ntombikayise refused to give up, and through her actions and imprecations found a way that happened to lead to Njabulo's 'return to life'.

\section{Longing for a child}

In spite of the distinctiveness of Ntombikayise's and Njabulo's relationship, it took place in a context of broader social relations and expectations. One of the great expectations of marriage is that children be born into it. When Ntombikayise and Njabulo came to know of Ntombikayise's HIV-positive status, they learned that unprotected sex would increase the virulence of the HI virus in both of them. They tried using a condom. As Njabulo, referring to a condom, remarked, 'They say a coat holds the cold at bay' ('Bathi ibhantshi liyawabamba amakhaza'). Use of a condom, however, interfered with Njabulo's virility, and with ideas concerning what was appropriate for sexual relations within the context of a proposed marriage, a space in which intimacy and the exchange of fluids is most positively expressed. Both Njabulo and Ntombikayise wanted a child. To try and 'keep the virus down' they decided to limit sex to once a week. It goes without saying that the sex was unprotected. Shortly after the marriage in January 2004, Ntombikayise's menstrual periods ceased, although she was not pregnant. It was unclear whether this was stress related due to the progress of the virus in her own body, or whether it signalled the onset of early menopause. She was 35 years old at the time.

Ntombikayise confided in the counsellor who counselled her husband before he began taking ARV treatment. Both she and Njabulo belonged to a support group based at the hospital they attended. In discussion with the young man who headed the group, she said:

My child [a common way of greeting a younger person], as you can see I am HIV-positive, but I want a child because I am at my husband's house [emzini]. At my husband's house they are waiting for a child ... Now I am getting confused about why they do not start, my periods. My husband is sad that I no longer have my periods. That is what is troubling us badly, because we do need a child. Pray for us. We want a baby. People from my husband's house want to embrace, hold with their arms [ukugona] a child, want to look after a child ... Now that we are trying, we cannot have a child. But a child is a gift from God. We are waiting. If God wants to give us a child, we will have a child. If he does not want us to have one, we will not have [one]. (Interview, 26 May 2004)

Although Ntombikayise and Njabulo's relationship produced fecundities apart from procreation, the absence of a child was a painful leitmotif within it. In what I have described above, I have chartered the negotia- 
tion of a relationship between two individuals, Ntombikayise and Njabulo, as I came to understand it, and specifically the support each gave to the other over periods of time and at points of particular vulnerability. Each individual showed magnanimity towards the other: Njabulo, through refusing to allocate blame for the illness, and insisting on the completion of their marriage; and Ntombikayise, through refusing to give up on their quest for healing. Through Ntombikayise's protracted insistence that they go to a 'place of free medicine', even in the face of Njabulo's unwillingness to do so, he was able to regain his vigour and strength through being one of the first people in the district to join an antiretroviral treatment programme at the district hospital, and as a consequence, could resume work in the building industry. In refusing to give up on one another through adversity, the love between the two deepened, and the respect Njabulo had for his wife became palpable in his public declarations of her courage in the face of his near death.

Although theirs is a story in which the predominant gendered location of physical and day-to-day care is upheld - that is, where a woman, ill herself, nurses and cares for a man through his illness - Njabulo's willingness to join Ntombikayise on a public platform in telling the story of their love and its intermingling with illness and healing, suggests an amplification of regard, one for the other, and of respect beyond that which is often overtly given. ${ }^{32}$ The weight of the act of appearing together in public may be appreciated if we take note of the fact that in general, men in the area did not publicly discuss their illness, and that there were ways in which men presented themselves that militated against certain kinds of speech in public that have to do with intimacy and vulnerability, and that in certain ways women spoke the silence of men..$^{33}$ In appearing together in public, in listening to each other's 'testimonies' with respect and mutual confirmation, Ntombikayise and Njabulo demonstrated an achieved friendship, a visible equivalence. Although there was deference, one for the other, it was the deference of admiration, and contained surprise rather than power.

At one of the meetings I attended at which Ntombikayise and Njabulo spoke together, a pastor asked how it was for them to speak in public. Implicit within his question were fears around the vulnerability of general exposure. He asked: 'When you speak about a thing like this among the people, what is your experience of speaking in front of so many eyes?' To which Njabulo replied:

We are free, open with this. Again we warn the people that they should look at this with different eyes. We declare that it is better for people to see everything clearly in the open. People must realize that this thing should be examined closely, because it is really something that exists. [Sikhululekile kuloko. Futhi sixwayisa nabantu ukuthi bathi ukubheka ngamanye amehlo. Sithi abantu ababone konke kusobala naku kubonakale ukuthi ngempela lento kumele iqapheleke ngoba into ekhona.] 
Ntombikayise concurred, saying:

I myself support $b a b a$ [father]. Yes, there is the problem that when you speak you may become anxious. But it comes back to you that there are many souls who are dying. Right now, our children are dying a great deal of this illness. It is better that we speak about the story, the news so that the people who depart [die] are fewer. [Manje abantwana bethu bafa kakhulu yilesisifo. Kungcono siyikhulumeni lendaba ukuze abantu abahambayo babe yingcosana.] There is HIV! There is AIDS! In truth now, this is why we live with great courage. (Ntombikayise and Njabulo speaking at an AIDS education workshop, Busingatha, 27 July 2005)

Ntombikayise and Njabulo came to the point where they were prepared to be seen to be open about their pursuit of health and the accommodation of the illness. Thus although Ntombikayise was an exemplary daughter-in-law, proudly taking on the range of practices associated with ukuhlonipha, practices of respectful avoidance in relation to her husband and his kin, what emerged over time was her strength of character and agentive action in relation to family and the wider world. Consequent upon her success in negotiating the illness with Njabulo, Ntombikayise extended her openness about their illness to her sister-in-law, and, after Njabulo's health had improved due to antiretroviral treatment, to her mother-in-law. She spoke with numerous neighbourhood women, for example, at the communal tap where they collected water. Not only did her openness result in many people in her neighbourhood testing for HIV, but her mother-in-law also began to insert knowledge gleaned about the illness from her daughter-in-law into conversations between neighbours at her home.

\section{Part two}

\section{Gift exchange in a marriage}

Within their personal relationship, Ntombikayise and Njabulo offered one another particular kinds of care. Yet they lived in a social setting where expectation, power and gender-difference were folded into the daily practices and norms of care. Their wedding marked the formal recognition of their relationship by their families, friends and neighbours, and the exchange of gifts before and after the wedding enabled a staging of ideals of care and regeneration. In the face of their illness, they gained public recognition through the gift exchanges that legitimized their union.

The ways in which gift exchange creates sets of obligation and indebtedness through time between the parties involved in exchange is already a well-established theme in anthropological literature, as is rivalry, or 
staged antagonism between families offering a member in marriage. ${ }^{34} \mathrm{I}$ choose rather to highlight a submerged theme within gift exchanges in relation to marriage in Okhahlamba, one that has been largely ignored, and that has to do with publicly held metaphors around care and domesticity. The gifts exchanged in the build-up to Ntombikayise's and Njabulo's wedding, for example, bore a relation to the daily nature of care. I suggest that the ordinary tasks in serving others in domestic life take on meaning in relation to a 'language' of the objects used in carrying them out.

The drawn-out elaboration, and indeed elaborateness, of the exchanges - their mounting drama and tension - suggested the magnitude, importance and status of forming a formally recognized marriage for the pair, as well as for their families. The exchanges, too, in the ways in with they marked a mounting oscillation of approach and seeming withdrawal, mirrored the playful delay and building-up of flirtation and desire. In fact, some of the gifts in early courtship bore a relation to the aesthetic appreciation, beauty and maintenance of the persons being gifted. One example is the various gifts given to the bridegroom and his umkhongi. Ntombikayise and her family gave Njabulo and his umkhongi each a set of clothes, including an outer blanket onto which mirrors, toothbrushes, combs and money were affixed: all items that referred to and enhanced the attractiveness of the men.

\section{Objects and the metaphors of care}

On a visit I made to Ntombikayise's mother, high up in the mountains of Thintwa, she summed up the cycle of gift-giving between the Bhengus and the Dladlas, from June 2000 to December 2003, when the wedding eventually took place:

The story of umabo: I am going to call it umabo, because we [the bride's family] went to distribute gifts. It starts with amalobolo nomcelo [the opening of marriage negotiations around bride-wealth for a girl]. The requests, izicelo [for gifts for the bride's family] are taken [by the groom's umkhongi]. Some call them izibizo [things called for]. The izicelo are brought [to the bride's home], then the cattle [lobolo] are seen. This means that the groom is committed.

He comes to call them, [the bride's family] to come and see the lobolo cattle. They went to see the cattle. They were all there. We could see that the groom was really serious.

Then we realized that we had to start to gather pickings [izingcosho], little things, gifts. ${ }^{35}$ By then the cattle had been seen. The groom's party came back to ask about umembeso [where the bride is dressed in clothes appropriate to being a bride and where some of the requested gifts are given to the bride's family], and to ask how many we were [for the purposes of gift-giving]. We told them that there were twenty of us. Then they gave me a pot and 
some other things. Then they went back to prepare [the gathering of gifts]. And we were also left to prepare.

It went on and on, and Ntombi picked things up when she went to Bergville [a small regional town]. If we had some money, we gave it to her ["simgodlise", meaning, "we held her"]. She would buy things [izimpahla] and come back with them, things for herself, and for people at her husband's house, that she liked. (Interview, I6 June 2004)

Much has been written about ilobolo cattle (bridewealth cattle), as well as the symbolic resonance between people and cattle among southern African peoples. ${ }^{36}$ Yet writing concerning the exchange of other 'little gifts', the 'pickings' (izingcosho) alluded to above by Ntombikayise's mother, is comparatively threadbare. ${ }^{37}$ Although Krige refers in passing to gifts distributed by the bride to her new family, there is no exploration of their possible significance. ${ }^{38}$ The latter omission may have to do with their seemingly humble domestic nature, and the fact that many of them are given to, and some of them are made by, women. As is well known, early anthropological accounts are weighted in favour of an overall emphasis on cattle and men's wealth, as is legal literature.

During the umembeso and umabo ceremonies of Ntombikayise's and Njabulo's marriage, the Dladlas and Bhengus reciprocated with gifts for all older members of each respective family. The latter gifts included a sleeping mat made of thatching grass, a pillow, a sponge mattress and a blanket. The same gifts were put aside for older people who had died in living memory. As ancestral shades of both men and women are intimately connected with the ongoing well-being of the living, through their intervention in everyday affairs and most specifically in conception and desire, their inclusion in the handing out of wedding gifts is to be expected. ${ }^{39}$

Additional gifts were given to the bridal pair's parents. Even though Njabulo's father was long since deceased, he received a number of gifts over and above those given to everyone. All four parents received large enamel basins for bathing, soap and towels. The three parents who were still alive received sets of clothing appropriate to their gender: in the case of the women, pinafores, head-scarves and shawls, and in the case of Ntombikayise's father, a large trench coat. Both women were given tea sets, a teapot and a tray.

Ntombikayise's mother and her mamezala (mother-in-law) received gifts that at first may surprise. These included a blanket called isaka lokutetela' (the sack for giving birth), an imbeleko, a shawl used to carry an infant on the back, and a large blanket for shielding a child from air (umoya) and its sometimes malevolent influence. It was repeatedly claimed that that the blankets given by a daughter-in-law to her motherin-law, and by the son-in-law to his mother-in-law, were to thank each woman for having given birth to their respective partner. The set of gifts aimed at restoring what had been taken from each woman in the process 
of giving birth and marked, in some respects, the passing on of the responsibility for procreation to the next generation. ${ }^{40}$

The bride's gifts to her mother-in-law marked her entry into a home in which she was expected to produce children for her husband. It was expected that she would take on her mamezala's role in contributing to the continuity of the lineage into which she had married. The gifts drew attention to the hierarchical relationship between mother-in-law and daughter-in-law, and yet showed their 'equivalence', in that they were both 'strangers' who had come to contribute to the ongoing life of a family and a patrilineage not their own, by providing children and by undertaking work within the homestead.

To return to an itemization of gifts given: Ntombikayise's mother received a large, three-legged, cast-iron cooking pot from her son-in-law, and Njabulo's mother received a number of beer strainers, izivovo, and eleven brooms called, 'amasondo ezinkomo' (hooves of the cattle). The eleven brooms equalled the number of cattle asked for in ilobolo negotiations, and tangentially referred to the work Ntombikayise would accomplish within the homestead under the jurisdiction of her mother-in-law: work that had been compensated for through ilobolo. Exchanging cattle for brooms marked the exchange of cattle for work.

Ntombikayise also gave Njabulo's deceased father a clay beer-drinking vessel (ukhamba), a meat-tray (isiqenge, uqwembe) carved out of wood by men, a similarly crafted spoon for eating, and an enamel food-dish with a lid. They, too, are gifts that have a bearing on fertility and nurturance, as well as the service required from the daughter-in-law in relation to her father-in-law. It was stated that the enamel food-dish, for example, would be used to offer food made by Ntombikayise to her father-in-law at the umsamo, the place in the homestead where one made offerings to ancestral shades. The lid placed on top of a dish symbolized the ways in which she, as a daughter-in-law, would cover herself respectfully in the presence of her male in-laws.

Ntombikayise's mother likened the gift of the clay drinking vessel to a womb. As it was made of clay, it was associated with the ancestral shades who live in the earth and are named abaphansi, those from below, or of the earth. In offering beer to her deceased father-in-law at the umsamo, Ntombikayise would be making her husband's ancestors aware of their indirect responsibility in contributing to her future fertility through creating desire and sexual 'heat' in her husband. ${ }^{4 \mathrm{I}}$

A few of the above-mentioned gifts, including the $u k h a m b a$, have to do with hospitality, or forms of care beyond the parameters of a family: the cast-iron pot used in cooking food for feasts, is another, as is the isiqenge, the wooden meat vessel which men use to pass seared meat amongst themselves during ritual feasts. A clay drinking vessel is associated with the importance of relationship between kin and neighbours. Beer is drunk to draw attention to the importance of social relationships, including those accrued through marriage. ${ }^{42}$ 
The isiqenge, a wooden meat-platter carved by men, shares another symbolic equivalence with the ukhamba (beer pot), because they are both used to offer sustenance to ancestral shades. Small pieces of meat from an animal that has just been ritually slaughtered are placed on the dish when meat is offered at the umsamo. The meat is then burnt together with impepho (helichrysum miconiaefolium, a herb associated with them) on blackened pottery shards (izindengezi), so as to be made 'palatable' for ancestral shades. ${ }^{43}$

Hand-crafted objects carry emotional weight, as does the daily use and meanings of common gifts given to all - the grass mats and blankets. Gifts made by hand - grass mats, wooden meat trays, clay beer pots, brooms, beer strainers, wooden spoons - bring with them the high value attached to objects made from materials gleaned in the environment in which people live. ${ }^{44}$ They set up a resonance between people, the living and the dead, and nature. In their use and in their staging, they at times evoke a state of being where the person using them may experience a deep sense of 'being at home'. Having been made by hand, they uphold the value of artistry and skill, and the degree of self-reliance these imply. What are the attributes of a 'feeling of being at home', if not rituals of nurturance, together with attempts to contain the uncanny aspects of intimacy and the malevolence of everyday life? Crafted and bought objects, exchanged at the wedding, are used in caring for children, cleansing and caring for the body, sharing and cooking food, the sometime pleasures of sexual intimacy, and shielding individuals from pollution.

Ntombikayise's father gave his umkhwenyana (son-in-law) a bedroom suite, and even if Ntombikayise and Njabulo do not sleep on the grass mats during their marriage, grass mats are nevertheless associated with sexual relations and procreation. A large number of them were stowed on top of the wardrobe in Ntombikayise's and Njabulo's bedroom, two of which were given to Phumzile and myself as gifts. Sex is never referred to directly, but is called, 'the work of the mat'. Grass mats are used widely as presents to friends, visitors and neighbours, and are spread out daily for women to sit on.

Blankets have a wide number of associations, and their use is pertinent throughout a life cycle. They are used in the process of giving birth. They are used to cradle a child. The blanket given to each child, and the ceremony performed in introducing children to their ancestors, is still referred to as imbeleko, a reference to the sacrifice of a goat for this purpose and its skin used in the past to carry the child. Blankets are used to keep warm at night. They are used to shield female mourners from view, to create a sympathetic darkness around the body of a chief mourner, who is always a woman, because of the pollution of death. The blanket forms a covering over the body when a person is steamed with medicines aimed at dispelling pollution. They shield and mark a person's vulnerability, the fact of their being 'out of sorts' in occupying a place of liminality. 
In Okhahlamba, at every funeral I attended, each person was buried with a new sleeping mat and new blanket. The placing of the latter objects on top of the coffin in the open grave constituted a powerful moment, in which the continuation of care and social relationship between the living and the dead was demonstrated. From the point of view of the living, placing the objects in the grave suggested responsibilities in caring for the dead, and an appeal to the dead to sustain the living through their assistance in procreation.

Arjun Appadurai (2003[I988]: 5) points out a 'powerful contemporary tendency ... to regard the world of things as inert and mute, set in motion and animated, indeed knowable, only by persons and their words'. Yet, as I have described them above, objects utilized in the domestic sphere become steeped in associations with moral values, with care and generation. Gifts given to the living and to the dead etch a continuum of care, straddling both worlds.

In his famous book, The Gift: The Form and Reason for Exchange in Archaic Societies, Marcel Mauss (I990) suggests that things exchanged are imbued with attributes of the givers and are therefore a gifting of a part of the self. ${ }^{45}$ The latter may particularly be said of hand-crafted objects. Mauss (ibid: 47) elegantly expresses our need for others and for social ties. Thus, in gift exchanges, one is giving and returning 'respects' or 'courtesies'. And that by giving, 'one is giving oneself, and if one gives oneself, it is because one "owes" oneself - one's person and one's goods to others' (emphasis in original text). The latter ideas echo precisely Ntombikayise's words in recalling that in spite of her husband's illness, '[he] had offered [himself] to her', and '[she] had offered [herself] to him'. Things given are not inactive, but are 'invested with life', seeking equivalents to replace them (ibid: I3). The concept of ubuntu, or humane relations, is predicated on the idea of an ongoing generosity of exchange, and the claim that a person cannot live in an optimal way without obligations to others. It is one's relations with others that enable the good life.

People in Okhahlamba cannot conceive of everyday care or ritual without the incorporation of quotidian, yet highly significant, objects. Viewed in the latter way, gift exchange can be likened to an exchange of substances, what Mauss has termed 'spiritual matter' between 'clans and individuals' and 'distributed between social ranks, the sexes, and the generations' (ibid: I4). In exploring the nature of gifts exchanged in the marriage of Ntombikayise and Njabulo, I have highlighted the resonance between objects, the meanings with which they are invested - in particular, fertility and fecundity - and the human task of striving for continuity of care and of ongoing generation.

Given that Njabulo's and Ntombikayise's world is shaped by the force of a political economy, where poor people meet frequent challenges in sustaining themselves, challenges that are exacerbated profoundly by a life-threatening disease, we may concur with Mauss's idea that, 'Gifts to humans and to the gods [in this case ancestral shades] also serve the 
purpose of buying peace between them both' (ibid: I7). There are many ways in which ritual is held up against an imperfect world, attempting to re-stitch or right it. Ritual is often experienced as preparing for better futures in which the inadequacies of everyday life, its disappointments, sufferings and shortcomings may be overcome. The staging of ideals of care in gift exchange is held up defiantly in the face of the realities of social life, in which we may fail to care for one another, or in which continuity of care between generations may be blocked through infertility and death.

\section{Conclusion}

I wish to briefly allude to some philosophical ideas concerning love in the work of Julia Kristeva and Emmanuel Levinas, which may have relevance to the tale of love I have told. In their work, love, in its most open form, is linked to renewal and rebirth for the lovers concerned, prior to any procreation. Kristeva (1987: 4), for example, writes that love is: 'capable of transforming an error into a renewal - remodelling, remaking, reviving a body, a mentality, a life. Or even two'. And that the pain it inflicts 'bears witness to the experience of having been able to exist for, through and with another in mind'.

For Levinas (1989: 49), Eros does not imply the fusing of one person with another, or a sense of completing an alienated self through love, as was, for example, posited in aspects of Greek Philosophy. ${ }^{46}$ Rather, the pathos of love for Levinas is that it preserves alterity, 'an insurmountable duality of beings'. The person one loves withdraws into their own mystery. The expansive qualities of desire, and of touch, suggest an open future for lovers. ${ }^{47}$ In being surprised and reshaped within the throes of love, lovers enter a form of communication associated with fecundity. Levinas is therefore at pains to convey that Eros, as communication, differs from possession, power, and knowledge. The unfolding of Ntombikayise's and Njabulo's relationship may be said to have likewise generated its own fecundities in relation to the emergence of mutual respect and admiration.

Ntombikayise once showed me a photograph of herself and Njabulo captured in a stylized moment at their wedding reception. In it, she held a cooked chicken-leg up to Njabulo's mouth, and he simultaneously held a spoon of beetroot salad to hers. Ntombikayise and Njabulo open their mouths to receive the food given, each to the other. To my mind, the photograph captures a staged moment of equivalence, symbolic of the importance of mutual nurturance and care. In many ways, the love between Ntombikayise and Njabulo has lived up to an ongoing exchange, one in which both persons have been reshaped and renewed in relationship with one another. 
The account I have given of Ntombikayise's and Njabulo's relationship, however, neither implies seamless transformation within the presence of death, nor an easy accommodation of the challenging effects of illness. For them, the ways in which death, possible infertility, and disease may work against what is life-giving, particularly in relation to the longing for children, was an irresolvable paradox. It was as if the illness became an unexpected child, requiring constant care and vigilance - a vigilance that called forth bitterness in relation to the absence of children and hence of generational continuity.

At the time of writing, Njabulo's $\mathrm{CD}_{4}$ count had risen from 70 (when he was first tested for HIV) to 500, and Ntombikayise's had decreased slightly from 750 to 705 . Ntombikayise's menstrual periods had returned. Given the latter fact, and Njabulo's increasing health, they revisited their 'dream' (iphupho) of having a child. In spite of her high CD4 count, a doctor placed Ntombikayise on antiretrovirals to protect any potential child from the virus in the event that one was conceived, and to try to lesson the effects of cross-infection of the virus due to the exchange of body fluids in unprotected sexual intercourse.

The presence of HIV and AIDS raises many difficulties in relation to fertility, the social insistence on procreation within marriage, and the wished for continuity of generations. Endemic ill-health becomes folded into processes of conception, whether through the effects of an early beginning to ARV treatment, or in increasing the strength of the virus in HIV-positive partners, if sex is unprotected, or in the possibility of passing on the virus to an unborn child. Ntombikayise's and Njabulo's story may be envisaged as one which extends ideas of lack of protection from individual medical risk to that which encompasses social risk: both forms of 'unprotection' that rub up against one another in irresolvable ways. There is lack of protection in relation to disease, in not using a condom whilst making love. There is the potential lack of social recognition and sanction, in not having children with an attendant withdrawal of ancestral recognition. Yet in the midst of such difficulties, facing illhealth led to a quality of relationship for Ntombikayise and Njabulo that continues to delight both themselves and others. In appearing in public together, they opened a new social space in which, without their having set out to do so, they had become activists. 



\section{On Accompanying the Ill}

In I994, following the first democratic elections, the new South African state sought to create a unitary public healthcare system. It was to be a particularly daunting task, given the uneven, discriminatory and inequitable structures that had been inherited from the apartheid state. Out of a number of parallel and racialized health services, the new state planned to bring together and yet to decentralize health delivery across national, provincial, district and community levels of organization. Resources and services were to be distributed between the different organizational levels in order to provide a 'continuum of care' for patients through various forms of referral that, in addition to hospital and clinic care, encompassed community and home-based care (Marais 2005: 64).

Great emphasis was placed on supporting communities in carrying out their own immediate care functions. Promulgating 'the community' as a potential resource for care followed on from primary healthcare models in which people on the ground necessarily formed an integral part. The notion of community-based care, aligned as it was with the ideas of self-reliance circulating globally within neo-liberal discourse, had particular local appeal for an emerging nation, in which each person was 'called upon' to play their part, and in which 'local solutions' were high on an Africanist agenda. Indeed, relying on community-based care was not only envisaged as an activity that would solve issues of scale, quality and sustainability, but also as one that would contribute to community solidarity and mutual assistance. In the terminology of the 200I National Guidelines for Home-Based Care/Community-Based Care (DOH 2оога: 3), a bed-rock of community-based care was envisaged as something that would encourage 'traditional community life' and create 'responsibility' within particular localities (Mills 2004: 3, DOH 200га: 3). The latter idea demonstrated a surprising confluence between local systems of solidarity - on which poor people undoubtedly depend - and the ideal of ubuntu, a history of cooperative struggle in confronting the apartheid state and neo-liberal ideas of self-reliance (Marais 2005: 66).

In the guidelines, written before the availability of antiretroviral medication through the public health system, care was defined as 'the provision of health services by formal and informal caregivers in the home, in order to promote, restore and maintain a person's maximum level of comfort, function and health including care towards a dignified death' (DOH 200Ia: I). One of the rationales for shifting care away from formal institutions on the part of the medical 'fraternity' had been the fear that the formal health system would become flooded with AIDS work to such 
an extent that there would no longer be space for attending to treatable conditions (DOH 200Ib). Through limiting the numbers of patients admitted to hospitals, many AIDS patients who sought hospital assistance towards the end of their lives were medicated and told to return home, as was seen in the case of Nkosinathi in Chapter One. From a hospital's point of view, no purpose could be served in admitting patients for whom 'nothing further could be done'. By shifting the bulk of care for the chronically and terminally ill into homes and communities, the state sought to avoid a situation where care at the formal level would be compromised or 'rationed' in unacceptable ways (DOH 200Ia: 2). Yet in doing so, the formal health system obscured individuals' experience of rejection, when turned away after seeking hospital help. From the point of view of Nkosinathi, for example, not only had his family failed him, but his attempt to secure help from both a clinic and a hospital was in vain. The one person who assisted him with any consistency, apart from a sister, was Zinhle Vilakazi, his home-based carer. In the last chapter of the book, I therefore turn to a detailed exploration of the work of homebased care. ${ }^{\mathrm{I}}$

The chapter outlines developments within home-based carer organization in Okhahlamba, from March 2003 to December 2005. Set up through the instigation of the Provincial Department of Health, the group of initially 77 home-based carers were unpaid volunteers who received some training in nursing, and who cared for the ill in their home areas. Remaining close to my interactions with Zinhle Vilakazi - the home-based carer to whom I became particularly close, and with whom I lived for short periods - I describe the assistance she offered patients in her home area and beyond. The account straddles a period in which individual carers at first felt helpless in the face of the inevitable deaths of their patients, and then moves on to a time in which antiretroviral treatment became more readily available. Carers were now able to witness, in many instances, the positive effects of the medication for those who accepted treatment. In charting some of the changes within homebased care organization, and linking these to Zinhle's particular story, I point to the volunteers' collective and growing sense of their position as brokers between different constituencies in their region, including the formal health system. I conclude the chapter by considering the structural underpinnings and social consequences of the state's reliance on poor and unemployed women for the provision of day-to-day care for the ill and the dying.

In March 2003, Zinhle, Phumzile and I set up a widows' supportgroup for three HIV positive women whose husbands had died in the late I990s, when little was known in Zinhle's neighbourhood about HIV and AIDS. Zinhle supported the women through their husbands' deaths and their own mounting ill-health. The women were to convene nearly every month at her homestead for the duration of the research period, and still did at the time of writing. The group's membership ex- 
panded to twelve in October $2005,{ }^{2}$ to include younger women and wives who joined after a public meeting convened by Zinhle, in which antiretroviral medication had been discussed. With the hope that antiretroviral therapies promised, as well as the sometimes soothing qualities of conversation, the support group renamed itself Umthombo Wempilo (The Fountain of Health). I left Okhahlamba in February 2006. Thereafter, the group began meeting jointly with another group from a different area to which some men belonged.

Although Zinhle had tended a great many families from the time she became a home-based carer in I999, she and the women of Umthombo Wempilo insisted that people were reluctant to join because it publicly identified them as living with lesisifo (this illness). In most areas, men distanced themselves from support groups, as in the case of Mandla Shabalala described in Chapter Two. He and many other men preferred to deal with the illness alone, or within intimate sets of relationships.

I begin with an extract from a conversation within the widows' support group that took place before antiretroviral therapies were accessible through the public health system, and through other initiatives. ${ }^{3}$ As I recall it, the conversation evinced a deep sadness, as well as the wearying physical effects of the ongoing presence of HIV. In the women's exchanges, corporeal suffering made its presence felt. Their words, mingling with non-verbal forms of expression, took on the qualities of a sombre musical composition. There were no lasting ways in which the unfolding of their pain could be stemmed. Nevertheless, references to pursuing health and livelihoods were made through referring to activities Zinhle supported. The difficulties and arduousness of tasks undertaken in everyday life became apparent, because they demanded physical stamina where there was in reality a depletion of bodily forces. The women held up reflections to one another in ways that offered comfort and praise. Yet, the co-presence of Tholi, a woman wracked with coughing, who silently wept, marked a certain acknowledgement of the failure of words. Her suffering, therefore, formed a counterpoint to the encouragement offered. Laughter, erupting at the end of the extract, created a brave, comedic stance, even in the face of pain - a sometimes necessary disassociation from flesh that had become all too present. That it was also a disassociation from Tholi's pain remains evident. In our speaking, our silence and our inadequacies, I became aware of an overwhelming heaviness in my own chest. It seemed that life was being lived within the taking of each laboured breath by our friend. Yet, our audible exhalations as a group, when a story of determination and accomplishment was completed, affirmed life:

THOLI WEEPS

Tholi: I am not feeling well.

THOLI COUGHS 
Zinhle: Yesterday we collected wood from the poplar grove to build the enclosures for our home gardens. ${ }^{4}$ That is the reason everyone is feeling worn out. Ma'Hlatswayo (Mary) ${ }^{5}$ told me she was ill during the night because of being tired out.

THOLI WEEPS

Zinhle: Now do not cry, Mam'Mbele (Tholi), because we were all sick.

Tholi: No, it's just that I am suffering from the chest.

THOLI COUGHS

Mary: Yes, we are all sick. Yesterday when we carried wood everyone said, 'No, I am going to die today!' But that was good of you, Mam'Mbele (Tholi). Although you know that death is here, you did not say. 'My! I am dying'.

Phumzile: When did the chest start, Mam'Mbele?

Tholi: On Tuesday when I was on my way to Dukuza.

THOLI COUGHS

... I went to check for my disability grant money. Although I had received notice that it was at the office, the officials there said it had not yet been deposited. They said we should come back on 3oth [of October].

Phumzile: Sisi Qinisile (Sister Qinisile), how are you?

Qinisile: No, I am better than the last time. I am taking TB pills and they are helping me. Yet when I carry something big the load kills me.

Phumzile: You talked about going to the clinic for an injection. I did not ask what the injection was for.

Qinisile: They injected me with an injection. They said my TB was very high. They said I had to have an injection everyday for two months. I started walking to the clinic on the 28 th of July. I walked down in the morning and came back on foot in the afternoon until it was the 28 th of September, until I had finished (a five-hour walk). I was only able to do this because of the encouragement of Mam' Mkhize (Zinhle), our home-based carer. I finished my injections. Now I am taking TB pills for six months. They said umkhuhlane (a general term connoting influenza of different kinds) was very strong in me. So they said they were going to give an injection to boost the [TB] pills. It helped me. It woke me up. I became better because when I finished taking the injections I felt that I could even run.

THOLI COUGHS

Qinisile: It is much better because I am able to eat. My appetite is back. (Ngivuleke inhliziyo.) I can now eat, and that coughing, I don't cough that cough anymore that I used to cough. It was a real help.

EVERYONE SIGHS

Patricia: And you, Ma' Hlatswayo (Mary)?

Mary: There is nothing bad, but I also have been suffering from the chest. It has been three weeks now since I started suffering from the chest. Mostly it is blocked. I can feel my chest. It is like a chest of an old man who is a drunk. You see, it seems it is just going to fall in. It goes bho! bho! bho!

(General laughter)

THOLI COUGHS

(Widows' support group meeting, Io October 2003) 
Several broad themes are related to the above extract. One has to do with a situation of scarcity in which human and material resources were unavailable or withheld, and in which institutions were often harsh, faulty, overburdened and corrupt. In such circumstances, people often only had words with which to comfort one another. Through the course of their work, home-based carers frequently offered the people whom they supported certain kinds of language and communication that sought to repair social relations, or that stood against the unravelling of relationships that some patients faced. The latter tactful, often religious and loving speech was set in contrast to an apprehension of the effects of poisonous kinds of language use and rumour that circulated within families, neighbourhoods, and even within the formal institutional domains of the hospitals and clinics.

Another theme that emerges from the conversation concerns the support that home-based carers gave to patients in accompanying them through activities in relation to their health and livelihoods. The broad extent of home-based carers' activities was for the most part invisible to outsiders. Those who have not witnessed the scale of their work are unable to recognize the patience and time invested in mediating their patients' visits to hospitals, clinics, and government departments in pursuit of social grants, and in visiting them in their homes. Everyday forms of care offered by home-based carers in cleansing, feeding and soothing the ill, as well as the mediatory roles they often played within family groups, were generally undervalued and taken for granted as unquantifiable forms of women's and girls' work. ${ }^{6}$ The lack of recognition afforded to the work that was done by home-based carers is therefore difficult to redress. Their work also became unquantifiable, because it touched the 'private' surfaces of everyday life; that which was intimate, secret and hidden.

\section{Zinhle Vilikazi}

On the afternoon I first came to stay with Zinhle, Ndevu Hlatshwayo, an old man, together with Siyabonga, Zinhle's seventeen-year-old son and only child, were painting her kitchen wall and fixing a door. A week earlier I had met Ndevu on the road outside Zinhle's home. At the time, support-group members were accompanying Phumzile and myself to our vehicle after a meeting. Ndevu volubly greeted us there, and declared to all those present that Mam' Mkhize (Zinhle) had helped to raise him from the place of the dead ('Wangivusa kwabafileyo'). He then pointed to another woman in the group, saying, 'You see! You also awoke from death through Mam' Mkhize'. Zinhle had successfully seen Ndevu through a period of medication for tuberculosis, and he now showed his appreciation for her persistent and considered care through repairing her homestead. 
In the evenings when I came to stay with Zinhle, we would sit together on a grass mat, singing hymns before going to bed. As Zinhle was a dedicated member of the Seventh Day Adventist Church, this was her usual evening activity. She told me that the grass mat had been given to her by a widow whom she supported through her husband's death and through her period of mourning when there had been little to eat.' Zinhle made certain that the woman and her family did not starve. The widow presented Zinhle with the mat she had woven before relocating with her children to distant relations, because of poverty.

Literate volunteers kept exercise books in which they recorded the dates of their visits to patients, the state in which they found them, and whatever tasks they performed for them. In April 2003, when paging through her notes, Sibongile Mdletshe, another home-based carer, asked me, 'Should I tell you about those who have died, who have gone (abahambile), or those who are living?' Her book seemed a haunting memorial, a kind of reliquary, in that the majority of entries referred to people who had died, recalling their demise and their deaths, each marked by a thick black line, underscoring her last visit to them. In juxtaposition to records pertaining to the dead, the entries concerning those who lived seemed to mark inevitable trajectories towards death. This was particularly the case because antiretroviral medication was unavailable at the time.

Zinhle, who read a little, but could not write, carried the dead and the living with her in other ways that bore witness to her long involvement with and knowledge of her home area. In Chapter Two, I mentioned the map I drew on her instruction through Zinhle taking an imaginary walk along the roads and paths outside her home. In mapping homesteads, Zinhle asked me to mark each with the number of people who had died there from October 1999, when she had begun her work as a homebased carer, to September 2003, when we constructed the map. In each case, I was told whether the deceased person was a 'father' or 'mother' of the homestead, a 'child-of-the-home', a father's brother or sister, or mother's brother or sister, a bride-of-the-home (umakoti, a son's wife), a grandfather or grandmother, or a 'child of the children-of-the-home'.

As mentioned in Chapter Two, when we came to count up the number of dead, in 86 out of Ioo homesteads within her home area, they amounted to I70 people. The majority (37) were 'children-of-the-home', a category of persons that indicated young adults from approximately fifteen to 35 years old. Children-of-the-home included the young husbands of some of the 22 'brides-of-the-home' who had also died. The next highest deaths were amongst the 'mothers and fathers-of-thehome', where 20 fathers and I2 mothers had died. 'Mothers' and 'fathers' were mature adults between 35 and 55 years old. Deaths among the very old and the very young were extremely small in comparison to the other age-groups. ${ }^{8}$ What was particularly painful for Zinhle was that seven deaths had taken place in one homestead, and six deaths each in 
two others. She asked that I mark twelve people as being ill at the time the map was constructed. Although not all of the deaths Zinhle mentioned could be attributed to AIDS, it seemed to her, with her experience of the trajectories of illnesses related to the disease, and with the number of people who confided in her concerning their HIV status, that the majority were.

One other reason why I asked Zinhle to recollect some of her past work through our co-creation of a map was that I, as a stranger, did not want to intrude in homesteads into which I had not been invited, and that were labouring under the burden of grief. As time went on, I came to know people living in eight homesteads around Zinhle's home. In each of these lived a person afflicted with AIDS, who through Zinhle's promptings had tested for the disease.

In spending time with Zinhle during the course of her work and her everyday life, and in visiting her frequently in her home, I came to recognize her exceptional qualities as a volunteer. She was respected by people of all ages in her neighbourhood, by people from other areas who came to hear of her, and by the home-based care network of which she was a part. It was said of her that, 'igama lakhe liyaduma' (her name thunders), meaning that her name preceded her.

I give a brief description of the range of work carried out by homebased carers through outlining Zinhle's activities. I came to learn that many of her activities were common to a core group of approximately 43 home-based carers who regularly attended monthly meetings, where they shared accounts of their work. Yet, it must be said that not all home-based carers were able to carry out their work with equal dedication. The reasons for this were often due to harsh circumstances and their attendant fears.

Of the nine women whose involvement in home-based care I closely followed, one woman's husband was so violent that all his children refused to live at home. His wife was completely overcome by ongoing violence and scarcely moved beyond her own homestead. Ironically, far more material resources had been used in constructing and furnishing her husband's home than the homes of any of the other home-based carers whom I came to know well. The woman had appealed to her husband's colleagues, all policemen, to confront him about the violence in his home. They told her that they were equally afraid of him, and suggested she appeal to a social worker. There being only one travelling social worker in the sub-district made the idea that she would ever receive meaningful support inconceivable.

Another woman, although dedicated to her work as a home-based carer, struggled to support her ten children - five of her own and five of her deceased husband's. After having been a home-based carer, she became a community health-worker, receiving a small monthly stipend from the provincial department of health. Soon thereafter, she became ill, and it was concluded that she was being called by her ancestral 
shades to become a diviner. She had previously been a Christian of a fundamentalist variety, and her family and friends shunned her when she entered training to become a healer. This was because of her particular church's unequivocal rejection of 'traditional' spirituality. Although the woman made great efforts to support herself and her children, her life seemed one in which a series of conflicting demands and competing world views repeatedly undermined her attempts at creating a lasting sense of equanimity. Yet in all her relationships with care work of differing sorts, she remained committed to the idea of providing a service to those around her.

One other woman continuously returned to the memory of her exhusband who had divorced her and abandoned his children seven years previously. Her return to her natal home in Okhahlamba shamed her, because her parents were not in a position to support her. She consequently hired a one-room house for herself and her children, and lived a precarious existence. She was a profoundly lonely woman who, although she did some home-based care work, was predominantly preoccupied with her own family's problems and the past. Her obsessive return to the past compromised her abilities to listen carefully to the people whom she served.

Returning to an account of Zinhle's undertakings as a home-based carer, their scope cannot be confined to any narrow definition of homebased care. Her strengths as a home-based carer drew fundamentally on many important aspects of her own life, as well as on her familiarity with the circumstances her patients faced. The overarching reasons for the respectful way with which she was regarded were that she took time in supporting iziguli (the ill) and their families, and was a tactful negotiator in situations of conflict. She was clear and unequivocal in the information she gave community members about HIV and AIDS, and the changes in treatment and procedure offered through the clinics and the hospital. She skilfully accompanied individuals in their application for various governmental grants, patiently helping them to reapply when their first attempts were unsuccessful. She was prepared to visit families at all times of the day or night, apart from the day she attended church.

In the early stages of the epidemic, Zinhle taught family members how HIV was contracted, and tirelessly persuaded patients to test for the virus at clinics and hospitals, often accompanying them on their arduous journeys to and from institutions. She was open about the fact that she herself had tested for HIV. She trained family members in how to bathe and feed patients when they were extremely ill, and in many instances undertook the latter tasks herself. She spent hours speaking with patients who were alienated within their families, and who had retreated to a place of painful silence. In forming such relationships, she frequently became the one person to whom an ill person could speak in detail about their illness, fears and circumstances at their homes. She gave patients emotional, physical and often religious support in the face 
of their families' fears, and with the approach of their own deaths. She not only accompanied patients to clinics and to hospitals - trips that at times required more than a whole day's commitment - she also attempted to negotiate transport and funding when there was none, at times carrying patients on her back to transport nodes with the help of a widow from the support group.

Before the arrival of antiretroviral therapies in Okhahlamba, Zinhle and other home-based carers arranged regular trips to the distant district of Msinga in KwaZulu-Natal, where due to special circumstances, antiretroviral therapies had been available from November 2002. The homebased carers were inspired to take their patients to the Church of Scotland Hospital in Msinga after their own visit there in September 2004. ${ }^{9}$ They undertook journeys with their patients to the hospital so that they could receive antiretroviral therapies when it became necessary to do so. Accompanying her patients to and from Msinga involved catching ten different taxis for a complete return journey, when a group of patients did not have sufficient money to hire a vehicle to transport themselves. It was a round trip that covered a distance of 420 kilometres.

When families whom Zinhle had tended through a number of deaths could no longer afford a coffin to bury one of their members, she negotiated with a local counsellor to set aside some funding for their proper burial. ${ }^{\mathrm{IO}}$ She attended many an isililo ('wake' prior to burial) ${ }^{\mathrm{II}}$ and the funerals of her deceased patients, asking neighbours to contribute food to funeral feasts when families no longer had the resources to do so. She donated her own resources in supporting families, particularly widows and their children, when they periodically ran out of food, drawing on her family's maize-meal reserve - ground maize from the yearly harvest that was housed at a milling works in Bergville. She initiated broadbased meetings at a public venue in her community, where neighbours spoke and learnt about HIV and AIDS, and were informed of changes in the provision of medication through the public health department, as well as the dangers of taking medication that was not properly monitored.

Through developing tact, and yet through knowing when to state her views clearly and unequivocally, through familiarity with local conceptions of and explanations for disease, and through learning the art of speaking patiently with family members, she came to persuade increasing numbers of people to test for HIV and later for $\mathrm{CD}_{4}$ counts. She tirelessly tried to support individuals in regularly taking their various medications, including antiretroviral therapies, and when her efforts failed, continued trying to persuade individuals and their families about the benefits of doing so. Because of her exceptional qualities as a homebased carer, people came to hear of her from neighbouring areas, and individuals often approached her to assist them when there was no home-based carer close by, or when they were dissatisfied with the ways their own home-based carer treated them. In visiting patients in other 
areas, she caught taxis, often at her own expense, and in Nkosinathi Dladla's case (explored in Chapter One) she crossed a mountain to the neighbouring community on foot to regularly visit him.

\section{Life experience and philosophy in relation to becoming a volunteer}

As a member of the Seventh Day Adventist Church, Saturday was the Sabbath and a day of rest for Zinhle. She referred to her fellow congregants as amaSabatha (those of the Sabbath). She attended church for at least half the day every Saturday. No cooking or work of any kind, including home-based care work, took place on that day. Food cooked on the previous day was shared between congregants after the service. It was Zinhle's religious convictions that prompted her to begin certain activities that led smoothly into home-based care work, as will be seen below.

In September 1999, a sister at the clinic near Zinhle's home read out the contents of a poster to her that called for volunteers in unpaid homebased care work. The work, being unpaid, did not overly distress Zinhle at the time, as such volunteering seemed to complement steps she had already taken in 'ministering' to people who were ill and in prison. In a context of failing resources and little assistance, prayer remained one possible balm. Before becoming a home-based carer, Zinhle and a friend decided to visit the local prison and clinic once a week to pray for prisoners and patients'. In visiting the latter institutions, they drew inspiration from a particular biblical passage from the Book of Matthew. In Zinhle's words:

When diseases appeared unexpectedly, the [diseases] that are here, lesisifo [this illness, a reference to HIV], death, it worried me, seeing people sick and dying, even our neighbours, it was very bad. It was not good. It worried me. I used to visit them nevertheless, saying a prayer because there is a verse in the Bible, although I cannot remember where it is. It says: "I was in jail, imprisoned, you did not visit me. I was in hospital, sick, you did not visit me. You ask whether people saw me when I was sick and hungry". Then it says, "For those little people, what you did not do for them, you did not do for me". ${ }^{12}$ When I remembered this verse, I started thinking. I was a believer, seeing people who are sick and everything. I took a decision about people that are sick. I wished to pray for them. I asked others from the church to pray for sick and dying people. (Interview, 26 March 2003)

Chapter 25, verses 34 to 46 from the Book of Matthew is a prognostic text in which Christ proclaims how he will group those who have upheld his teachings on his right-hand-side, and those who have unknowingly failed to do so, on his left. In an envisioned future, he informs his 'true' followers that in all his incarnate vulnerabilities they have succoured 
him by feeding, clothing, and housing him. As a stranger, they have welcomed him; they have attended to him through illness, and have visited him in prison. The followers insist that Christ has not been in a position where compassionate actions on his behalf were necessary. He then tells them that in responding to the suffering of ordinary people, to 'the least' of his 'brethren', they have indeed in each instance acted on his behalf. Christ contrasts those who have alleviated the suffering of the 'least' of his brethren to those, on his left-hand-side, who whilst they may have attended to Christ himself have ignored 'ordinary' people.

Zinhle's words were an appropriation of the second part of the passage in which the suffering of 'little people' is ignored. Their implied inversion of an optimal world resonated with Zinhle's own experience of material scarcity and often emotional depletion; one in which succour was not always to be had.

In relating to me additional reasons for her taking up the work of home-based care, Zinhle drew on aspects of her past. As a girl, she suffered from ongoing illness, and as she matured, her father refused her permission to marry because of her persistent poor health. He was concerned that a husband would not have the wherewithal to care for her consistently. She nevertheless married the man of her choice. In Zinhle's view, her experience of being sickly as a child and as a woman enabled her to be sympathetic towards people who were ill. Because of her ill-health, she regarded the birth of her only child as 'miraculous'. In Zinhle's words, her experience of being treated successfully in hospitals consolidated her 'faith' in procedures offered by medical doctors:

\begin{abstract}
A thing that inspires me is that I greatly feel the pain of a sick person, because sickness is a thing I grew up with, and I live with it now. So now, when they say a person is sick, I worry, thinking that he is not happy. Sickness always makes you unhappy. You cannot see to yourself. You cannot go where you want to go. You cannot even be happy if people sit with you for a long time. When you are unhappy [because] you are sick, you stay in bed, you go to the hospital. You see that you are always troubled [uhlukumezekile] ...

Because of my own history, I like to get close to sick people ... Also, I wish to tell them that if they do what the health workers advise, they will live. I did not think that I would live this long, but I have by listening to what they said at the hospital. My body is marked by the scars of many operations I needed to get better. I think that there were three that I had to have. I teach my patients by giving them hope that when you do these things [suggested by the doctor/health worker], you live. (Interview, 26 March 2003)
\end{abstract}

In relation to broader philosophical ideas touching on personhood and ethics, Zinhle explored notions of being human through relationship, and the responsibility that being human bears: 
When I grew up, my mother told me that you can never be a human being on your own. A person is a person because of other people ... So now I often think about those words. I think of a house that has been built. It is not yours alone, but is for everybody. So now when a person comes to this house my heart is at ease. I know that because this person is a human being, I am also a human being because of her. My mother used to say that a home that no one visits is not a home. When you have a home, it must be a home for other people as well. When you have a home, you ought to cook. Your home should not be a place where people visit or pass by only to die of hunger ... A person must be given some porridge so that she does not die of hunger, because that person may have come from afar ... That is how we were brought up; that is what she told us.

That is what I always think: a person is a person because of another person. God also says the same thing. He says, "Love your neighbour as you love yourself". But this [idea] that a person must help his neighbour is linked [to what we have been saying]. God did not only mean that we should only help our neighbours that are near us. He meant every person is your neighbour, because you are on this earth. So then, I like people.

I like people very much. When I was growing up and still at school, I had lots of friends. Even after I got married, I still had many friends. The father of this house [Zinhle's husband] usually says: "You have a lot of friends girls, children, grandmothers, grandfathers. All these people are your friends!" I tell him that I know how to live with other people, how to laugh with other people. So I will not give up my friends because I like other people. He even says when we buy things for the house, "I am buying chairs for your friends to come and sit on". This shows that he knows that I am a person belonging to people. I love people by nature. He has also come to accept this. He no longer worries about it. You know, there are a lot of people coming to this house! A lot of people come to this house! So, I really do not have a problem about a person coming, and I am very happy about it.

I always say this is the truth. I often go visiting in Johannesburg. By the time I come back I have made a lot of friends. Another thing that my mother used to say is that when you go to a place, you have to make friends there. You must not think that when you have left, you have left all your friends behind. You ought to be able to live with the people you find wherever you go. She used to say: "There are friends where you are going to. You will find them when you get there. You will find other people and then make friends". So now I can see that there are friends wherever you go. I have found you [Phumzile Ndlovu and Patricia Henderson] and you have become my friends. By walking with you, by going with you to home-based care [meetings], I have found friends. I can see that my mother was right when she said that there are friends wherever you go. Wherever I go, I find friends, so I see that as the truth. (Interview, 7 October 2003)

In the above account, Zinhle draws on ethical and philosophical ideas that have a large circulation in Okhahlamba to do with the importance 
of generosity within social relations and the notion of ubuntu, where the emergence of self is only possible because of the individual's relation to others. It is clear that Zinhle's renown was linked to her expansive sociability, her willingness to listen to others and to spend time with them. Hers was a pleasing expansiveness that enriched her sense of self. It was an expansiveness related to new people she might meet in widening social contexts, a responsiveness open to what was not necessarily familiar.

I use an image derived from botany to draw out the qualities of Zinhle's sociability, as I understood it (see Taylor I990). Fractal branching increases the surface area of a plant, enabling it to absorb more nutrients and sunlight than would be possible if it were a solid enclosed mass. Each branch or stem supports the growth of further branches that, in turn, do the same. The expansiveness suggested in the branching structure of many natural forms allows an imaginative envisioning of how Zinhle's world expanded through a range of relationships within and beyond her home area and that crossed institutional domains. It is the range of such relationships that has enabled her and other homebased carers to make contributions to the health system; one's that should to be acknowledged.

The relationships that straddled Zinhle's life were ones that encompassed urban and rural spaces; that reached beyond her home-area to other neighbourhoods and districts, providing possibilities for comparison and therefore for critique; that closer to home connected her with each ward within Okhahlamba through the home-based care network and the NGO through which they were supported; that cemented conduits of communication between particular health personnel in the hospital and the clinics and community workers; and that provided unusual sorts of friendships, for example, with myself.

Zinhle's descriptions of why she did voluntary work were not unlike the accounts given by other committed home-based carers. Their explanations showed how new forms of work were folded into local notions about care within families and within gendered subjectivities. They drew on their status as mature women with a lifetime's experience of providing nurturance within their homesteads and beyond. Their motivations were refracted through their pasts, through aspects of what they were taught, and what they had overcome. Cruelties experienced in early life were often offered up as the reason why women developed compassion in later life. They did not want others to suffer in the ways they had as children. ${ }^{\mathrm{I} 3}$ The women frequently referred to their religious predilections, whether these were of a Christian or of a 'traditional' sort, or a combination of both. ${ }^{\text {I4 }}$ Their motivations were also linked to social relationships that increased volunteers' sense of themselves as a collective grouping that could take action on the part of their patients.

New social and knowledge-based possibilities opened up for volunteers through the work, and constituted an expansion of their social 
worlds and of their social standing that they enjoyed. They became brokers within their communities through mediating in conflicts within families, through introducing members to new developments in relation to treatment, and in accompanying the ill through institutions. They became brokers in other ways that fell outside of the bounds of being home-based carers. For example, they were well situated to identify the poorest families in their home areas, to whom quantities of maize were regularly donated by a group of concerned white farmers. ${ }^{15}$

Home-based carers praised the practical training in nursing they had received and their collective discussions in meetings, the mutual support afforded one another there, as well as the development of a knowledge-base to do with HIV and AIDS, of which their own experience and knowledge of their communities formed a vital part. Apart from providing altruistic motives for undertaking the work, many hoped that in putting themselves forward as volunteers, employment opportunities might arise.

Throughout the conversations and interviews I had with Zinhle, her one persistent complaint was that she received no financial reward for the work she undertook. Before she became a home-based carer, she augmented the small R200-a-month (\$24.57-a-month) allowance her husband gave her for 'extras' in the homestead by selling pinafores she had sewn. Married women often bought them for everyday wear. During the time I lived in Okhahlamba, work in road repair and maintenance became available through the municipality. Zinhle was eager to take it up. Patients and community leaders in her neighbourhood begged her not to do so, as they had come to rely on her care within families, and on her assistance in negotiating the bureaucratic procedures within clinics, the hospital and state departments. Being without earnings became particularly difficult when her husband returned home from his work as a truckdriver on the Witwatersrand with a collapsed left hip. He waited for over a year for a hip-replacement operation at Ladysmith Hospital. Soon after Zinhle's husband returned home, she helped him apply for a disability grant. The grant was finally issued eight months later, months during which Zinhle and her husband lived without a monetary income. In late 2007, Zinhle's husband was still unemployed and walked on crutches. He, not unlike Mandla Shabalala, whose story is recorded in Chapter Two, awaited a pension payout from his former place of employment.

Despite Zinhle's concern that she was not remunerated for her efforts in home-based care, her investment in the work was such that it seemed only a distant possibility she might relinquish it. In June 2007, however, she in turn had to have an operation to one knee that had collapsed under the strain of all her work and her walking. Although she recovered, the operation forced her to diminish the scope of her involvement. We see from both Zinhle's and her husband's state that the health of poor people, through a long process of attrition, is hard to sustain despite frequenting health institutions. 


\section{Home-based carers as brokers}

During the research period, home-based carers in Okhahlamba came to play a seminal part in seeking ways in which their patients could receive antiretroviral therapies before they arrived in Okhahlamba through the public health system. The most important precipitating experience in enabling them to do so was the visit of twelve of their members, including Zinhle, to the Church of Scotland Hospital in Msinga in September, 2004 .

Because of a badly injured leg, I could not accompany them on their journey, and so I asked them to write diaries of their experience. On her return to Okhahlamba, Zinhle, who could not write with ease, asked a young HIV-positive woman of twenty, Makhos', whom she nursed in her home area, and whom I frequently visited, to write down her recollections of the trip as she dictated them. Echoing the story with which I opened the book, Zinhle and a member of the widow's support group took turns to carry Makhos' on their backs to secure hospital care for her. Money to hire a vehicle to transport her from her home to the main road had not been available at the time. Makhos' was one of Zinhle's patients who would later survive on antiretroviral treatment. Her writing for Zinhle became a welcome gesture of reciprocation for the care and support she had received, and was, she told me, a process in which she became inspired by Zinhle's descriptions of the effects of antiretroviral therapies, as she had encountered them in Msinga.

Zinhle's 'diary' succinctly and with great lucidity documented her visits to five patients in the Msinga area, four of whom had begun antiretroviral treatment. In three visits, she listened to their stories of recovering strength and flesh, and of their return to work. In another case, a patient refused antiretroviral treatment because he persisted in attributing his illness to his ancestors 'sitting heavily upon him'. They had visited him with sickness because they were demanding certain rituals from him. In yet another, a young woman had begun antiretroviral treatment, but had suspended it because an aunt told her that the medication she now took was the cause of her illness. Her state of health then rapidly deteriorated. Her aunt, who was also ill, treated her niece and herself with herbal medicine. The aunt subsequently died. The woman told Zinhle she wanted to return to antiretroviral treatment, but was afraid of the doctor's response given that she had been warned of the effects of stopping and starting the medication. Zinhle's conclusions from the different accounts patients gave her when she visited them in Msinga were unequivocal. She had seen the positive effects of antiretroviral treatment and was determined to inform 'the ill ones' at home about them.

In an interview ten months after her visit to Msinga, Zinhle reiterated the impact of that journey: 
We went to Msinga last year to learn about the pills, about ikhambi [the name given to antiretroviral therapies], though our hearts were painful because we did not have them here in Bergville. It was painful for me, because I had people in a support group whom I did not know how to help. I only cared for them through speaking to them and learning who were HIV-positive. I did not know what I could help them with. When I arrived at Tugela Ferry [an administrative centre in Msinga], I heard about and saw the antiretroviral therapies. I wished to bring them here because I was thinking of the people who were left behind at home. What made me happy was that [the doctor at Tugela Ferry], when we asked him if we could bring our patients to him, he did not refuse, he did not prevent us from bringing our patients to Msinga. His response made me happy because I realized that what we had gone to Msinga for was not just to play [it was not in vain]. I even left the father of the home [husband] behind. He was at home on a holiday. He was at home for a whole week, having returned from Johannesburg. I thought that I should not let the opportunity go of learning about the pills, because I was thinking about my iziguli [sick ones] that I had here. I was happy after I returned from Msinga. I knew that I could send those who were ill to Msinga. I returned and brought the support group together. I told them. In a way that surprised me, they wanted to go to Msinga. The patients that I began sending to Msinga were five. When we arrived at Msinga the soldiers in their bodies [their CD 4 counts] had to be checked. What was found was that some had 500 soldiers. Three had very few soldiers, very low CD4 counts. One had 30, another 29 and the last 85. They started the pills. Right at the beginning, when they started taking the pills [literally "eating the pills"], we saw a great difference in them. The people who are ill are continuing with their pills.

It continued. I sent other patients to Msinga. I can't remember properly how many they were because I have been sending them regularly. Some patients got their pills and survived. Others did not survive [Ezinye zeziguli bezifika ziwathole amaphilisi zisinde ezinye futhi zingasindi] ... Two died. If I count, looking back to I999, I used to nurse, let's say ten or eleven people. Amongst these people I knew that even as I nursed them, even though they were not keen to check [their blood], I saw that they had HIV. Others checked. They told me [the results]. I knew that if there were ten [who were HIV-positive] they would all die, and I would start nursing a new set of people, and they would also die - all of them. [Ngangazi ukuthi njengoba bewu ten bazashona bonke ngiqalelephansi futhu nginese abasha, nabo futhi bashone bonke.]

I now see a difference because of the pills amongst those whom I started to nurse last year [2004], when the pills started. There are those that I now see who would have gone long ago [died] if they had not received the pills from Msinga. Of those who remain, only a few have died [abayimbijana]. The community sees this and says that going to Msinga has helped because there are those who are recovering. It is not as it was in the beginning when everybody died. I have seen that our going to Msinga has helped us a lot. I 
am so grateful that here at our Emmaus [Hospital] the pills have arrived, they have started. It is just that they have to become more organized. (Interview, 29 June 2005)

Home-based carers were inspired on their return home from Msinga to push for a speedy roll-out of antiretroviral therapies in their own area. Instead of seeing themselves as people who up until that time 'accompanied patients to their deaths'; had 'nothing really to offer'; 'delayed' or 'eased the deaths of their patients'; tried to comfort families when their relatives died, and intermittently supported families in their poverty, home-based carers found a renewed sense of purpose in bringing back the news of a therapy that, if properly administered, would prolong the lives of their patients in many instances.

When antiretroviral therapies arrived in Okhahlamba in March 2005, through the public health system, home-based carers continued monthly meetings with the doctor from the local hospital whom they respected and trusted. In the meetings, home-based carers communicated their concerns about gaps in local health protocols as they perceived them. Due to their now long relationship with the doctor, they were free and open in the questions they asked him. From the doctor, they received ongoing information in response to their questions about antiretroviral therapies, and explained to him social issues relating to the medication and any other problems as they emerged.

In Zinhle's case, for example, she was particularly concerned that ambulances in Okhahlamba neither fetched patients from nor delivered them to their homes. In order to board an ambulance, people who were ill had to find their own way to clinics. The experience of one young woman in her neighbourhood, who subsequently died, haunted Zinhle. A person had brought the young woman to the clinic early one morning, but had been unable to travel with her to the local hospital because of prior commitments. When the young woman returned from the hospital in the ambulance it was already dark and the clinic was shut. Despite this, she was told to disembark. As she was unaccompanied, she tried to stumble on her own through the dark in the direction of her home. After having walked for just over half a kilometre she collapsed at the side of the main road. It was a cold night, and rain began to fall heavily. The young woman was left to lie in water and mud. It was only by chance that a group of young men, walking through the night, found her. As no-one remained in her own homestead, she asked the boys to carry her to her neighbour, whom she said would make a fire for her to warm herself. It was not long afterwards that the young woman died. Zinhle related her story to me several times, and each time, we both felt the extreme sorrow of it. It was iconic and demonstrated how in uneven local circumstances, with eroding social connections, limited institutional reach and few resources, the intense suffering of people was amplified. 
Despite the particular problems revolving around transporting patients to clinics and hospitals, the doctor with whom the home-based carers frequently met was responsible for developing an innovative organizational framework that would ensure that antiretroviral treatment was made available to the largest number of people in the district in record time. ${ }^{\mathrm{I}}$

\section{The illegal sale of medication from a public health facility}

In October 2004, a month after the visit to Msinga, six home-based carers exposed a particular nursing sister engaged in the illegal sale of drugs in pill-form from her base in a free public health facility in Okhahlamba. When volunteers discovered that some of their patients were taking pills in large and often single doses that looked surprisingly like the antiretroviral therapies they had learnt to identity at the Church of Scotland Hospital in Msinga, they related these incidents at a home-based carer group meeting, inviting particular patients to speak of their own experience. Accounts emerged of how the sister had forced individuals to buy medication in secrecy through a skilful combination of authority, bullying and shaming. The home-based carers were especially concerned, because they knew of the importance of correct and regular antiretroviral dosage, life-long adherence to treatment regimes, and the effects of suspending treatment - understandings that were re-confirmed by the doctor in Okhahlamba with whom they had regular contact. The home-based carers informed other organizations at their monthly meeting about their suspicions. The then mayor of Bergville was alerted to what the sister was doing through a counsellor, who told him that medicine was being sold at a free clinic. Under pressure, the sister resigned her post. ${ }^{17}$ It would have been difficult to prove a case against her in court. Her selling medicine to patients took place behind closed doors, and it was not clear if any patient would be prepared to testify formally. Commonly too, disciplinary proceedings within the Department of Health were notoriously slow and often inconclusive in completing of their tasks. ${ }^{18}$

On the 29th of October 2004, a month after returning from Msinga, Zinhle organized a large and important meeting in a community hall in her neighbourhood. People attending it included community elders and leaders, support-group members, people of all ages from Zinhle's home area and beyond, a number of HIVAN personnel, including Phumzile and myself, and the doctor and his family from Msinga, whom the twelve home-based carers had befriended on their visit to the hospital there. The doctor, who ran the antiretroviral programme in his district, addressed the meeting, answering questions from the floor concerning antiretroviral therapies, their effects and dosage. 
When he had completed his address, a home-based carer from outside of Zinhle's area introduced a young woman of 3I years, Busisiwe Ngubane. Busisiwe explained how the nursing sister at a local clinic had begun selling her pills, pills that were later identified by her home-based carer as antiretrovirals:

I am also infected with ingculazi [the virus]. I wish to tell this story because my confusion has now passed. At first I took TB treatment [treatment for tuberculosis]. I finished the treatment. It did not end. The home-based carer from my area visited me and encouraged me over a number of days to take blood. Since I had tried many places and ways of getting well, I said, "Please take me". She gave me R5 (\$O.7I) for the taxi fare. I tested and wanted to deny the results on the first day. The next day, because I was very sick, she took me to the clinic again. This time I was given Bactrim by the sister. ${ }^{19}$ After three months, the sister told me I needed to start her special pills. She took them out of her handbag and told me they would cost R60 (\$8.57). I trusted her profession, so I borrowed R60 from my neighbours and bought the pills. She gave me three packets and told me to take five at once. They nearly killed me. Blood poured out of me. My sickness intensified. I was now confined to my bed. I hid these pills from my home-based carer. But because they made me so sick, I later showed them to her. The next time I went to the clinic I wanted Bactrim. I did not want to buy any more of the pills from the sister. But she said to me, "You think you are trying to be clever? You don't want to take my pills? Because of your stubbornness I won't give you any Bactrim. You are the one who allowed yourself to become HIV-positive". She put me on the scales and said, "How can you say you are a human being when you weigh so little? You are nothing but rubbish!" I now have vaginal thrush and I do not know how I am going to treat it because I do not want to visit the clinic again. (Home-based care meeting, 29 October 2004)

Busisiwe continued that when she had complained to the sister about a lack of appetite, she had given her a depo-provera injection that she said would increase Busisiwe's desire to eat. Busisiwe noticed, however, that the sister made no record in her clinical notes of having given her the injection. Busisiwe wept as she related her story, as did many of us listening to her. Hers was a particularly poignant tale because it highlighted her poverty and social marginalization, her sense that all systems had failed her, and a particularly sickening abuse of authority on the part of the sister. Busisiwe decided to speak of her experience at an open meeting because a number of home-based carers from Okhahlamba and from Msinga had visited her in her homestead. ${ }^{20}$ They had helped to ease her confusion..$^{2 \mathrm{I}}$ During the visit, she introduced the volunteers to her son, a boy of ten, who was extremely ill with the virus, his body covered in suppurating sores. She told them that she did not want to take him to the clinic because of her prior experience there. The home-based 
carers and Phumzile helped her by giving her R30 $(\$ 4.28)$ to bypass the clinic and to take her son directly to Emmaus Hospital. She and her son had been well received there. By the time she spoke at the public meeting, her son's wounds were drying due to the medication he had received at the hospital, and he could sit up.

\section{Beginning a journey with antiretroviral therapies}

A young woman of 24, Sibongile Mzinyane, a member of Zinhle's support-group, was present at the same meeting where Busisiwe spoke of her clinic experience. Sibongile's nickname, MaHlombe eNip, suggested a woman who was so thin that her shoulder bones stuck out like quartersized bottles of alcohol. It was a name used in humour and with a degree of cruelty in her neighbourhood, and occasionally within Busisiwe's support group, where she had become a recent member.

Although Sibongile did not live in Zinhle's area, she had approached Zinhle three months before, asking her to care of her. She complained about the home-based carer from her neighbourhood, who persisted in shaming her by saying that she had HIV because of the wild life she had led in Johannesburg. At the support group meetings in Zinhle's homestead, Sibongile impressed me with her irreverent, outspoken and lively personality. She was tall. When she attended the public meeting where Busisiwe and the doctor from Msinga spoke, I was appalled by her physical deterioration. She was emaciated, and so ill that she could no longer sit up, but lay on her side on the floor on a grass mat, her head on a cushion and covered with a blanket that Zinhle placed lovingly over her. As I knelt down to greet her, she told me that she had insisted on coming to the meeting because she knew it was there that she would hear about the 'new medicines that brought hope'. The previous day, Zinhle had travelled by taxi to fetch Sibongile from her home. Sibongile stayed overnight with Zinhle so that she could attend the meeting the following day in Zinhle's neighbourhood. Her presence at the meeting, in spite her extreme ill-health, pointed to her tenacious spirit.

After the meeting, in which Zinhle sought to inform her neighbourhood about antiretrovirals, she was determined to take Sibongile to Msinga with the hope that she would be given the treatment. In order to do so, Zinhle, together with a number of other home-based carers, hired a small truck to take Sibongile and other patients on the journey to the Church of Scotland Hospital.

For some reason, perhaps because she had left her $\mathrm{CD}_{4}$ count results behind, Sibongile was sent home from Msinga without being admitted to the hospital. She was determined to get treatment, though, because the diarrhoea she now had suggested to her that death was near. Zinhle accompanied her once more to the Church of Scotland Hospital, pleading with the doctor to admit Sibongile to the hospice, where over a peri- 
od of some months on antiretroviral treatment she could regain some strength before returning to Okhahlamba. This time she bore her CD4 results with her. They 'said that [she] had only 29 soldiers left in [her] body'. Because she had been tested for the CD4 count some months before travelling to Msinga, she said that she would not have been surprised if 'only one soldier remained in [her] body', because her condition had deteriorated and she sensed the proximity of death.

Sibongile stayed at the hospice in Msinga for three months, a place known by patients at Msinga as kwaLindusuku, the place of waiting for the day, the implication being that if one entered the hospice, one was simply waiting for the day of death. Sibongile claimed that many of the patients in the hospital's general wards were too afraid to go there when asked to do so by the doctor. Yet Sibongile was treated so well in the hospice that it felt like home. She had begun taking antiretroviral therapies: 'Stocrin, the medicine that goes with TB (tuberculosis), 3TC and iStavo (Stavudine) 30, the medicine for a person whose soldiers are below 6o'. She said of her relationship with antiretroviral therapies, 'You drink them. You eat them the whole time for your whole life until you carry soil with your chest' (Uyawaphuza. Uyawadla isikhathi sonke impilo yakho yonke till uze uthwale umhlabathi ngesifuba') - an allusion to death and burial. (Support group meeting, 8 February 2005)

Sibongile's condition improved greatly with the excellent treatment she received in the hospice at Msinga. Because she felt well, she asked her doctor if she could return to Okhahlamba to her family for Christmas. Zinhle went to fetch Sibongile and to accompany her home. During the same month, Zinhle accompanied another member of the support group, Nonhlanhla, to Msinga to collect her supply of antiretroviral therapies. Zinhle's journeys to fetch Sibongile and to accompany Nonhlanhla were long and arduous. They were also characterized by 'adventures of the road'. I asked Zinhle how many taxis she had to catch to get to Msinga and what the fares were. She replied:

You take five taxis. From here in my home area, it is R7.50 to go to Bergville. From Bergville to Ladysmith it is Ri5. From Ladysmith to Uitval at Ekuvukeni it is Rio. From Uitval to Pomeroy it is Rio. From Pomeroy to Tugela Ferry it is Rio. The total is R52.50 (\$7.50). With the return journey it is Rio5 (\$I5) per person. (Support group meeting, 8 February 2005)

Of her trip with Nonhlanhla, Zinhle said:

Here on the roads you have to sit and wait until each taxi is full [before it will begin a journey]. We kept on getting onto, getting onto taxis. When we reached Ekuvukeni, we were supposed to get a taxi going to Ladysmith. It was dusk and there were no vehicles. We were afraid about what we would do, because it was close to the time for Nonhlanhla to eat her pills. She was on the road. There was no water, there was nothing. It was hitting seven [it 
was nearing seven p.m., the time for her to take her pills]. We were in a field. I said, "Because it is dusk let us go to people's homes before we are caught by criminals". I said, "Let us go and ask for a place to sleep". We saw beautiful houses. I said, "Let us look rather for one that is poor and ugly, because the people who have built beautiful houses, like township people, they won't accept visitors" ... We entered a yard. They invited us in. When we went into the house we saw photographs with jackets [graduation gowns] hanging on the wall, and were worried [because we thought the people there would not help us]. It was the home of ebaThenjini [praise of the Mthembus]. We found young women who [had graduated] as school teachers. They lived with their grandmother. My! They welcomed us extremely well. We greeted them and asked for water to drink, because the time was passing and it was time to eat the pills. They gave Nonhlanhla water and she drank her pills. They cooked food for us and we ate. They made us sleep in a double bed in the room not used by any one. We slept very well at the home of people we did not know. We woke up in the morning. They made tea for us. We left and returned home. (Support group meeting, 8 February 2005)

Of her return journey home with Sibongile (S'bo), after she had commenced antiretroviral treatment, Zinhle said:

In December I went to go and fetch S'bo, so that she could come home to eat Christmas. They gave her pills for the time she was going to spend at home. She put them in her small handbag. I carried her large bag and her blanket. We climbed onto taxis, and got off and climbed on again. When we left Ekuvukeni for Ladysmith, it was chaotic [phithizela]. There were many people. It was December. ${ }^{22}$ We climbed onto a taxi going to Ladysmith. Just before we arrived in Ladysmith, Sibongile said, "Oh Ma! I forgot my bag on the taxi”. We looked and realized that the bag containing her pills had remained in the last taxi ... S'bo began to cry. I spoke with the boys [drivers] from the taxis, asking whether they knew the taxi we had left behind. They said they knew it and that perhaps the owner had gone back to Uitval. There was nothing that they could do. I said it would have been better if there was some other problem. What were we going to do about the pills? It was clear that now we had to go back to Msinga to the hospital. But we did not have money to return. By seven it was important that these pills be found [so that S'bo could drink them on time]. The boys said, "One of you should go to Ealing Road where the taxis arrive. The other should remain here so that if the taxi comes here first, she can identify it”. I suggested S'bo remain because she was still weak. I would go to the other taxi-rank in Ealing Road to look there. I asked the boys whether they had the phone number of the taxi driver. They found it and phoned him. They asked him whether he had seen a black handbag. He had. They asked him to bring it. By that time I felt free, although I new S'bo would be very sick where she was, because she was extremely worried and sad. 
Sibongile: I fainted. Someone put toothpaste in my mouth to try and revive me. He took toothpaste from my bag and put me on a chair because I had fallen down onto the ground.

Zinhle: Once I saw the bag coming it was like a dream.

Sibongile: It is not desirable for a patient to travel by herself...

Zinhle: That is true. If you had been on your own, you would not have found your pills. It took us six hours to find the bag. We were very excited because we did not care if the money in the bag was lost or stolen. We knew that we would be able to ask people for money. But there was no other place where we could get the pills. We would have had to return back to Msinga. I was happy. It was as if I was dreaming. Only God knew where the bag was, and in the end nothing was taken from it. (Support group meeting, 8 February 2005)

It is the above accounts given by Zinhle of two journeys with her patients, Nonhlanhla and Sibongile, that point to the ways in which poor people struggle to accomplish what from an outside perspective may seem simple. They were journeys that were drawn out through time and that were only successful because an able-bodied person accompanied one whose bodily forces were depleted. On a broader level, it is perhaps the journeys beyond the peripheries of institutions that foreground unrecognized difficulties in the pursuit of health. Small errors, for example, Sibongile leaving her medication on a taxi, can have serious consequences. It was largely due to Zinhle's determination that Sibongile's medication was recuperated.

In reflecting more philosophically on the generous lending of body, and sometimes voice, sight and learning to others across the boundaries of differing states of health, a chain of recognition is set up between people that sometimes build social relations against the grain of geographies of power. To accompany people as Zinhle did on so many occasions, without discounting or patronizing them, was to act and respond with consummate care, care that had not only to do with certain appropriate actions, but with affective acuity. It is within the latter crossings between people, where the disempowered and ill also gifted those who cared for them, that a spacious sociality was created. Here each person was left with a sense of expansion in the face of ongoing difficulties, if only for a time.

Through Zinhle's journeying, I have suggested that her work formed an example of the efforts 'ordinary' women took on the part of their patients, efforts that were made against a background of shared poverty and illness, institutional incoherence and uneven state delivery. In the face of such realities, in my view, the Provincial Department of Health should be obliged to provide home-based carers with a stipend, in the same way that community health-workers currently are. ${ }^{23}$ This would help to decrease the numbers of carers who, because of economic pressures, leave their work after a time. ${ }^{24}$ It would go a little way in acknowl- 
edging the importance of the women in their provision of an indispensable service and, on a more philosophical level, the importance of care within everyday life in threading together relationships and in facilitating the exchange of various generosities, without which social life becomes untenable.

The educational levels that are at present the criteria used to assess whether people applying to be community-health-workers will be capable of delivering health messages are not always a useful indicator of ability. Many community-health-workers are young people who, although they may have received some secondary school education, are not necessarily regarded as persuasive in the areas where they live. It has been suggested that the same criteria be used to choose home-based carers in order for them to qualify for a stipend. In my view this would be a grave error and would automatically push aside those women without a formal education who have given so much of their time and effort already in caring for the ill. As in Zinhle's case, her abilities to care effectively for her patients were based on maturity, discretion, her non-judgemental attitudes, knowledge of her area, concern, wisdom and generous sociability. Her lack of education did not mean that she was incapable of acquiring knowledge about HIV and AIDS. She was an exceptionally intelligent woman who expressed herself with great lucidity whenever she spoke. Over time, she had also acquired long-term experience in negotiating often crippling bureaucratic processes, while assisting people with obtaining a whole set of documents, including death and birth certificates, identity documents and affidavits, all of which were necessarily in applying for state grants.

\section{Conclusion}

In what has been written above, it is clear that the South African state has overlooked a case that could have been made for the extension of its responsibilities, rather than their curtailment in relation to providing care for its citizens (Dalley i996: xiv, Sevenhuijsen et al 2003). In seeking to divert care away from hospitals and clinics, the 200I national guidelines dealing with community and home-based care made no explicit reference to gender (Hunter 2005: 5), yet overwhelmingly, it is unemployed women and girls who, despite the multiple burdens they already bear, have come to provide daily care for the dying and the chronically ill. The state's utilization of the above strategy has diminished its own economic costs in providing care, and shifted these onto poor women whose abilities and resources in taking care of the ill are taken for granted (Mills 2004). Assumptions about the separate realms of family and state underlie policy formulations dealing with community care (Means and Smith 1998). It is often within the so-called 'private' do- 
mains of family that care becomes mystified as a naturally occurring form of exchange.

In placing the above trends within the frame of globalizing neo-liberal economies and discourse, Hein Marais (2005: 65) points out that:

The ethic of care as household and community responsibility, its veritable "privatization", consigning it to the sphere of the home - has coincided with the increasingly implacable subordination of social life to the rules of the market ... [T] he responsibility for providence and calamity, for life and death is lodged with ever smaller units of society...

In strong language, Marais (ibid: 66-67) argues that the consequences of dominant neo-liberal thought is that a 'fetish' has been made out of coping and the notion of resilience in a context where people have limited choices, and in which the very idea of meaningful choice is questionable. In Marais' view, the effect of celebrating people's ability to cope when their lives are increasingly precarious and where added burdens are placed upon them through, for example, championing policies of community based care, is 'morally base'. He writes that the 'stereotypical image of the stoic, strong and silent "woman of the house" is a blinding caricature' (ibid: 68) and that women, through the burden of their work, are subjected to mental strain, emotional depletion and extreme fatigue. $^{25}$

Although I am generally in agreement with Marais, in that I acknowledge the structural marginalization of poor women, the extent of care they carry out, and the ways in which they bear intolerable burdens of work, mental strain and emotional depletion, I have told a story of a woman (who in her work shared similarities with many other homebased carers) whose efforts must be acknowledged and, dare I say, celebrated. How does one acknowledge the contributions of women who, from an analytical point of view, may occupy a place of marginalization, restriction and lack? It would seem to me that even in the most extreme situations, the efforts people make to support one another are of the utmost importance. This does not mean that the state has no responsibility with regard to extending its contribution in sustaining the lives of its citizens. There are many people within South Africa who live within the margins of the state (Das \& Poole 2004), who strive to make lives for themselves beyond, despite and up against its inadequacies.

Selma Sevenhuijsen (2003), a feminist political philosopher based in the Netherlands, is concerned with highlighting the necessity of an ethics of care at every level of society, a recognition of the importance and value of care that enables the reproduction of social life, ideally, in optimal ways (see also Tronto I993, Sevenhuijsen 1998, Young I997, Kittay I999, Walker I999, I998 and Urdang 2006: I67). She encourages a broadening of political value systems to include care, and suggests that daily care, the maintenance of 'the body', 'the soul' and of 
'relationships', lies at the base of 'good human functioning' (Sevenhuijsen 2003: 180-8I). In many parts of Europe, and indeed in wealthier parts of South Africa itself, 'care functions' are no longer located exclusively in the home because of women's increasing participation in the formal economy. ${ }^{26}$

In southern Africa, however, as demonstrated above, there exists an opposing trend. In impoverished areas, there is a continuing reliance on home-care for the ill provided by unemployed women. The acknowledged violence of gender relations in South Africa, and the often strict division of labour associated with masculinities and femininities militates against any widespread acceptance by men of carrying out direct care work. In some respects, the latter trend is the outcome of a long history of marginalization in which, during apartheid, women were discouraged from working in the cities and were often endorsed out of urban areas in order to entrench apartheid's homeland policy. Women were expected to secure rural homes, largely through their day-to-day efforts in subsistence agriculture. The labour of women and children in sustaining rural homes, in providing minimal subsistence, and in bearing some of the burden of their own survival, became the apartheid state's 'justification' for the low salaries paid out to working male migrants.

Much of what I have written in the chapter has considered the exchanges between people in the giving and receiving of care of differing kinds. I have suggested that it is in these exchanges, in which care has been sought, given, and acknowledged, that the reward of care and its meaning lie. As I have already mentioned in Chapter Two, even in the most extreme situations, what Levinas (200I: I20) has called 'senseless, incidental goodness in the human ... outside all redemptive institutions', contributes to stitching a social thread.

Returning to Sevenhuijsen, she writes:

The notion of human nature embedded in the ethic of care diverges from the unilateral individualism which is central to many a moral theory and thus also to the normative assumptions of many policy theories. Relationality and interdependence are core concepts of the ethic of care ... The guiding thought of the ethic of care is that people need each other in order to lead a good life and that they can only exist as individuals through and via caring relationships with others. (Sevenhuijsen 2003: 183)

She goes on to list the dimensions of care as a moral orientation and a practice, these being: 'recognition, responsibility, competence and responsiveness' (ibid: I84) - all aspects of care to which I have referred in this chapter and, indeed, throughout the book. Sevenhuijsen, as I do, discusses the importance of attentiveness in providing care. She speaks not only of care-giving, but of care-receiving and thus underscores the importance of the relationship between caregiver and receiver. The re- 
sponsiveness of the person receiving care is of equal importance in constructing an ethics of care. As I have shown in Zinhle's journeys with her patients, as well as the gestures of reciprocation on their part towards her, these have been journeys in which Zinhle's contributions have undoubtedly become visible to the persons she has accompanied and in which they have found ways of showing her their appreciation. 



\section{Epilogue}

The book has drawn attention to care as a form of hospitality offered between the relatively well and the ill and dying in Okhahlamba. Forms of care were described in relation to a particular kind of illness, lesisifo, more broadly referred to as HIV and AIDS, that has come to dwell among people in ways that compromise so much of social life and yet that call for its reconstitution. The simultaneous unravelling and remaking of sociality across the boundaries of the living and the dead made up the parameters of care in the region.

Care and its opposite were found at many levels of social organisation, the dimensions of which emerged within detailed accounts of individuals' journeys towards health and death in relation to their illness. Journeying in search of healing on the part of individuals also encompassed the qualities of variable and transforming social relationships in which they were immersed. The isolation and form of social death Nkosinathi, for example, experienced, as described in Chapter One, became manifest when his experience of extreme suffering remained unacknowledged by some members of his family. Silence and lack of recognition, the withdrawal of touch - that which insists on our humanity and on the possibility of exchange between persons - issued into being a form of profound alienation.

More generally, the unevenness of proffered care became manifest at the level of the state, in hospitals, in clinics, in relation to the comportment of nurses, home-based carers, family members and the self. Care and its intermittent withdrawal were linked to forms of institutional incoherence, where institutions bore the trace of histories of neglect and deliberate discrimination. In the intimate spaces of family, the sometimes refusal of care could be partially understood as due to state interventions within families, where mobility and migration resulted in forms of separation and estrangement - forms of separation where people nevertheless strove to reconstitute rural homes as sites of significance, and as social nodes where senses of particular forms of belonging were located.

The possibility of a degree of suspension of care within the family was also understood in relation to the visceral dimensions of undergoing AIDS, as a form of dismembering, not only of the material body, but of the social body. In Nkosinathi's and Mandla's stories (see Chapters One and Two), I have alluded to the returnee migrant as a person viewed with ambivalence - as an innovator and yet someone who could renege on consistently sustaining rural households and their social ties. Migrants 
coming home to die occupied households in profoundly sad ways: their deaths were a disappointment to remaining family members, who often depended on them for the viable continuity of rural life. To some extent, migrants carried the hopes of projected time, the longed for fruition of painstakingly gathered skills, for example, in education, in which all family members had invested.

In detailed stories pertaining to individuals, I have tried to capture how the weight of history became manifest in everyday cruelties, and at times, in dismissive assumptions about those seeking care at all levels of social organisation. Rejection of self and of others is painfully linked to such larger frames. The book therefore traces a scale of care from its broadest, least affective dimensions to its most intimate refusals and forms of gift giving. Such dimensions are linked to people's everyday practices of meaning making, health seeking, repairing, and sundering - for some dying and for others, caring for the dying. I have tried to show the expansive dimensions of what it meant to accompany people on their journeys through illness towards death, or towards refigured forms of life.

Exploring individual life trajectories through which the impact of larger social forces is glimpsed, has been a deliberate political choice on my part. More distanced descriptions of the AIDS pandemic have often relied on the authoritative weight of statistical claims to force recognition of its seriousness. I have sought to relate the human dimensions of suffering and grieving, and the extraordinary degrees of tenacity and perseverance people have brought to bear on pursuing care - efforts that often go unmarked because they cannot be imagined from the perspective of persons situated in worlds where certain operations are accomplished with relative ease. It seemed important to me to leave a record of lives described in detail, where with time few records will remain.

Given the predominant absence of meaningful state support at the time the research was conducted, people were obliged to draw predominantly on their own resources in crafting care. The state, occupying a position of absent presence, inured individuals and their families to the necessity of developing patience and persistence in relation to its bureaucratic processes. We have seen how journeys in accompanying the ill and dying took up inordinate amounts of time, a reality explored in detail in the relationship between of Zihle and Makhos' (see Chapter Seven). The acquisition of official documents: death and birth certificates, and identity documents - papers required at the time in submitting grant applications to the state, for receiving antiretroviral therapies through state institutions, and in exercising the basic rights of citizenship, for example, in voting or opening a bank account - were often impossible to acquire. Such difficulties were due to government offices being dispersed over large distances; their own administrative procedures split between spaces, ill-planned and susceptible to error; their offices ill-equipped, and their personnel open to corruption. Difficulties in 
acquiring documents also had to do with the nature of social relationships between people, for example, in family groupings, where deceased parents of a child had never married and did not live in the same homestead, or where a family was too poor to take one of their deceased members to a mortuary to obtain a formal death certificate.

It was due to generous forms of sociality in which individuals gave of themselves unstintingly in supporting the desperately ill, that certain individuals were able to survive at all. This was demonstrated in the loving relationship between Ntombikhayise Dladla and Olwethu Bhengu in Chapter Five and in the relationships developed between Zinhle and her patients. The untenable aspects of life, within what have been referred to as social margins within a neo-liberal global world order, are spaces in which demonstrable forms of generosity on the part of many people living there are of the utmost importance. It is in such contexts that the contributions of individuals begin to matter a great deal. I list here a few such acts that emerged strongly in the research. There is the example of a particular doctor's commitment to find the most efficient way of rolling out antiretroviral therapies with limited resources, through spreading services available in the hospital to the clinics. He developed a protocol whereby nursing sisters were trained to administer many of the preparatory and ongoing tests in relation to HIV and to run particular meetings with patients. He arranged that doctors would travel out from the hospital to the clinics to consult with individual patients once they had begun antiretroviral therapies. Other examples included the exceptional qualities of Zinhle Vilekazi as a home-based carer in her compassionate and respectful approach to the people whom she tended, and to their families. The dedication of the NGO worker, Phumzile Ndlovu, in sustaining the commitment of home-based carers in the region, often when there was no material support she could offer to them, required immense effort. Such forms of generosity also related to the moral economies with which people reconfigured the everyday, and in which they drew on a plethora of frameworks of meaning from forms of Christianity, to politics, to local cultural ideas concerning the crafting of relatedness.

In relation to the notion of generosity, there is also the embodied way in which accompanying someone afflicted with lesisifo on their healthseeking journeys, required lending the relative strength of a person's body to another whose bodily forces had been thoroughly compromised. This created a form of interdependence that required trust, finesse, kindness, and sometimes laughter, that insisted on the social location of the ill. I have shown how people in Okhahlamba used all their resources, including poetic ways of speaking, of navigating and of staying in relation to understanding the illness, caring for individuals and ritually accommodating the dead. I have therefore suggested the aesthetic dimensions of everyday life as a creative and malleable resource for various sorts of repair and of defiance in the face of unravelling sociality. 
In doing so, I have not avoided the harsh dimensions of individuals' physical demise in undergoing AIDS, or the ways in which political economy has rendered certain people's lives an unremitting challenge how economic relations and oppressive forms of power are embedded in and have shaped everyday life and exposure to illness. I have paid attention to details pertaining to cultural repertoires through which experience is made meaningful, for example, in descriptions of Ntuthuko Hadebe's and Nonhlanhla Duma's journeys towards becoming healers, through turbulent historical times, and the ways in which HIV and AIDS folded into accounts of their lives. Through their example, I have demonstrated how interpretations of illness are never solely confined to the failings of the physical body, but are necessarily located within political and historical horizons through which people have come into being as particular kinds of subjects. People in Okhahlamba experienced themselves as being set apart by the state, as having been forgotten. With this apprehension in mind, illness was interpreted in relation to dispossession, discrimination and exclusion.

I would like to expand on the necessity of tenacity in survival, in seeking treatment and in seeking care. On their own initiative, home-based carers, having seen the effects of the antiretroviral therapies in a distant hospital, organized trips to this hospital for their patients before medicines were available in their own region through public health structures. Similarly, children and young people who had lost one or both parents to AIDS actively sought adult care, and turned to local courtship practices to expand the number of people, on whom they could legitimately call for assistance. I have described how women and girls bore the brunt of everyday care for the ill, but also how men played an important role in ritual processes of recognising the dead and in guiding the spirits of the dead to their homes. New forms of sociality also emerged in the process of care. Home-based carers, who were predominantly women and unemployed, became linked to the wider world through their organisation, and experienced degrees of empowerment in taking up action on behalf of the people for whom they cared and in expanding their knowledge of HIV and AIDS through regular dialogue with a committed medical doctor. In the process of caring for one another through the illness, Ntombikhayise and Olwethu (see Chapter Five) transformed common gendered ways-of-being in their own relationship and, through example, opened up possibilities for critique in the public sphere.

Very few studies in relation to HIV and AIDS have paid attention to the ways in which the illness is folded into already existing social and cultural repertoires or how it has in turn affected such repertoires. The book begins to address such lacunae. The importance of doing so helps us to write against the grain of many studies where people living outside of the dominant frames of discourse are characterised by a lack of qualities and possibilities, by passive 'emptiness' or forms of abjection in 
need of outside intervention, where vulnerabilities are both externally defined and pathologized.

The book has also raised ethical questions in relation to the difficulties of doing research among people who are dying and has suggested the importance of recognition and appreciation of forms of meaning-making that in relation to dominant discourses may be easily dismissed as anachronistic, archaic or conservative. I have tried to show how it is these very modalities-of-being that have rendered people's lives meaningful, and through which they find the strength to persist.

Following people's journeys towards health through time, shows how people draw on numerous healing repertoires, treatments and forms of medication in the simultaneous or sequential use of medicines issuing from both 'bio-medical' and 'indigenous' systems of healing. The temporal dimensions of journeys therefore show the entanglement of these approaches to health in the everyday lives of individuals. In addition, individuals' journeys uncover complex crossings: the ways in which 'the magic' or allure of 'traditional' treatments associated with 'nature' are incorporated into bio-medical approaches through bio-medical testing, and the ways some of the 'technological wizardry' associated with biomedicine is imported into 'traditional' approaches in a staging of appeals to authority and modernity: recall Ntuthuko's pharmacopeia in Chapter Four in which he staged his authority through the prominent display of a certificate stating that he had attended a bio-medical training course on HIV and AIDS. It is in temporal accounts of such journeys that a clear demarcation between the 'traditional' and 'bio-medical' begin to blur. This does not discount the vital role antiretroviral therapies have played in prolonging the lives of individuals in the region, who had they not taken the medication, would have long since died.

Within the sphere of bio-medicine, Georges Canguilhem (20II), a philosopher of medicine, has outlined an increasingly pointillist focus on smaller and smaller dissections of the human body - a departure from earlier approaches under Hippocrates, for example, that encompassed a close observational focus on the individual person as subject in relation to their symptoms and milieu. He writes that diseases have become more and more localised in, for example, the organism, the organ, the tissue, the cell, the gene and the enzyme. Forms of specialisation born out of the above kind of focus tend to excise or render invisible the relational aspects of healing and of medicine. Canguilhem argues that what is left out of bio-medicine is the experience of undergoing illness, the individual living disease as a forfeiture, a devaluation. These precise concerns have constituted the focus of this book. 



\section{Appendix: Interlocutors and Research Methods}

As described in the Introduction, my two research assistants in Okhahlamba were Phumzile Ndlovu and Zanele Mchunu. Within the NGO where they worked, Phumzile was responsible for co-ordinating the work of volunteer home-based carers in Okhahlamba, who had trained in palliative care in I999, and who were responsible for caring for the ill in their neighbourhoods. Zanele undertook intervention work with 'vulnerable children and youth', to use the terminology of the NGO and global development sectors. She had ongoing contact with children and young people who had lost one or both parents through death.

Describing the scope of their activities in more detail, once a month, Phumzile convened a large meeting of all the home-based carers within the region in the NGO offices in Bergville, in which she encouraged them in their work. On occasion, speakers were asked to address the meeting, including personnel from the Department of Social Welfare, Treatment Action Campaign (TAC) members from Pietermaritzburg, and more frequently, a doctor from the local hospital with whom carers had formed an ongoing and open relationship. Phumzile also attended support-group meetings for home-based carers in four areas of Okhahlamba, where volunteers could speak of their problems in relation to specific patients and their families, and of their own emotional turmoil in the face of the suffering they witnessed. She recorded the minutes of intermittent inter-sectoral meetings of interested parties across local communities and racial divides, where their contribution to confronting the AIDS epidemic was discussed. Groupings involved included: church groups, the police, personnel from the provincial education department, a few doctors from the local Emmaus Hospital, charitable bodies, the personnel of a small local orphanage in which only two children lived for most of the research period, other NGOs, myself and interested individuals. Phumzile attended an AIDS task group meeting set up at Emmaus Hospital, to which I was also invited. I attended many of the above meetings, recording them and writing notes concerning my observations of them.

Phumzile introduced me to the home-based carers at one of their general meetings, during the first month of my living in Okhahlamba. The group was made up of 77 members, although on average, only 43 regularly attended general meetings. Only two of the carers were men. One man was the poet, Roman Khumalo, who came to compose poetry about 
HIV and AIDS and who at the beginning of the research period became a voluntary counselling and testing (VCT) counsellor at one of the clinics.

Nine home-based carers agreed to interact intensively with me over time. By visiting them in their homes, I was to record their life histories and the scope of their work. I conducted open-ended interviews with them in isiZulu that were recorded on tape, and accompanied some of them on their visits to patients in their neighbourhoods. During the latter visits, I gradually came to know a number of patients in ways that allowed ongoing visits to their homesteads. I became particularly close to one home-based carer, Zinhle Vilikazi, whose work is described at length in the last chapter of the book. I lived with her intermittently for one-week periods, accompanying her in her work with patients.

The home-based care group was founded in October 1999. Most wards in Okhahlamba, with the exception of a few more remote areas, put forward the names of potential volunteers who were then interviewed as to their suitability for the work. ${ }^{\mathrm{I}}$ Mam' Shabalala, a retired nursing sister, who received her training from Baragwanath Hospital in Johannesburg in the I96os, trained the volunteers in three groups and thereafter trained volunteers in neighbouring districts.

It was through our ongoing relationship with Zinhle that Phumzile and I suggested she set up a support group. In addition, Phumzile encouraged a number of other home-based carers to do so in other neighbourhoods. Towards the end of my stay in Okhahlamba, we knew of six support groups that met regularly, two of which Phumzile regularly attended. Zinhle's support group began with a small number of HIV-positive widows in her neighbourhood. Phumzile and I routinely attended their meetings and recorded them with the permission of attendees. In time, the group was to expand, particularly when home-based carers initiated a way of accessing antiretroviral treatment before they had reached the local state hospital. During the period in which antiretrovirals were unavailable in the region, Phumzile, on her own initiative, arranged for twelve home-based carers from Okhahlamba to visit the Church of Scotland Hospital in Msinga, a rural district of KwaZulu-Natal, where antiretroviral treatment and its roll-out had been established for some time due to support from an American university that had established a research partnership with the hospital. The visit was easily arranged because of Phumzile's prior friendship with a doctor at Msinga Hospital. The group of twelve home-based carers returned to Okhahlamba determined that patients in need of the medication would receive it, and on their own initiative, arranged for those who were particularly ill to travel to the Msinga District - a distance of approximately 210 kilometres from home - to access antiretroviral treatment. I recorded this development through asking the women to write diaries and through ongoing interviews and conversations with them about their patients, together with a weeklong visit to Msinga myself. 
One of the home-based carers, Nonhlanhla Duma (see Chapter Six), who had accompanied the group of twelve to Msinga, was a sangoma (a diviner). She was also HIV-positive. I developed a particularly close relationship with her. Growing out of our friendship, I asked Phumzile to introduce me to other healers in Okhahlamba. Together we visited eight healers recording their views of the HIV and AIDS epidemic and their explanations concerning local conceptions of well-being, health, illness and medicine.

Phumzile and I accompanied eight home-based carers who visited Emmaus Hospital for four days in Okhahlamba in order to nurse patients in the wards and to learn about the workings of the hospital. The visit was conducted with the hope of improving links between 'community members' and the institution, and gave me an opportunity to record my own observations of everyday care in the hospital and volunteers' responses to the situations in which they found themselves. On occasion, Phumzile and I visited three clinics in the region, accompanying patients there, and at other times recording the experience of VCT counsellors who worked from the clinics. We were able to record aspects of the 'roll-out' of antiretroviral treatment, at first through Broad Reach, an international body with several projects in South Africa, and then through Emmaus Hospital. On many occasions, home-based carers visited the office in Bergville to report problems in their neighbourhoods and in their own lives, as did community members, who heard of our work and who wanted to enquire about appropriate services, or simply to tell us their 'stories'. Many informal conversations in the office and in public spaces, including taxis, proved invaluable for the research.

During the same period, I worked with Zanele. Prior to my arrival in March 2003, she had begun what later became known as the 'Leaders of Tomorrow' (LOT) project - a set of intervention programmes for orphaned children and youth in three communities in Okhahlamba. The latter areas were identified as having high numbers of orphans through a survey that had been previously commissioned by the NGO. In Amatikwe (not its real name), a rural community situated in beautiful, mountainous terrain in which I would later begin intensive ethnographic research, Zanele began an intervention project with 3I young people ranging in age from fourteen to twenty, and made up of fourteen boys and seventeen girls. Older children and youth were chosen as members because it was thought that they would have more to contribute to income generating projects than younger children. The group did not want to be labelled izintandane (orphans) and chose for themselves the name, 'Leaders of Tomorrow', a name that was later extended to all projects. The reason for the young people's rejection of the term 'orphan' had to do with local associations attached to orphanhood with which they did not identify, associations that conjured up for them images of having no social place, and of being completely destitute. 
The intervention project that Zanele initiated with LOT in Amatikwe involved community gardening and the raising of chickens for sale. A respected community member made land available for these activities. During the course of weekly meetings with the young people at the secondary school most of them attended, Zanele helped them to plan the logistics of running their project. In facilitating meetings, she used a series of exercises derived from a body of motivational theory known as 'Transformational Leadership Training' - a set of ideas strongly reliant on self-examination and the setting of goals in relation to creating change. She assisted children and youth in solving ongoing problems to do with the running of the project, and in addressing practical issues such as the drawing up of rosters for the young people to work with the chickens, and in their garden.

When I first arrived at the young people's meetings in Amatikwe, I was struck by a general shyness within the group. Children and youth answered Zanele's questions with few words. It seemed that the venue itself evoked entrenched ways of interacting in classrooms reminiscent of a current teaching style in which pupils affirmed and echoed what teachers presented to them and did not ask questions. Conversation, when it occurred, was predominantly monopolized by older boys and girls. I came to learn that the young people's 'shyness' also had to do with the way in which children and young people in Okhahlamba were taught repertoires of respect that took the form of truncated verbal exchanges with older people.

In seeking ways in which the young people would allow a more 'open' relationship with us, I introduced a series of theatre games into our meetings. My aim was to create a sense of fun, unpredictability and immediate accomplishment. After a few weeks, the younger children began to lose their inhibitions and to interact with Zanele and myself more freely. I began more intensive research with the young people by visiting them in their homes. With ongoing visits, on which Zanele often accompanied me, we came to know each child individually, something that had not been possible in the general melee of the classroom. The children and youth were greatly excited by our visits, some of which required us climbing for several hours over mountainous terrain to reach their homesteads, the roads being impassable by vehicle. We began an ongoing cycle of in-depth interviews in isiZulu with each young person and subsequently their guardians. Visits to homesteads provided an opportunity to observe the circumstances in which they lived and to appreciate the long distances from many of their homes to their secondary school, and to their garden and chicken project. In early 2004, I accompanied children in a series of activities often undertaken by them to contribute to their households, including the inspanning of cattle, the collection of firewood, the cutting and selling of thatch-grass, and seasonal repair work to homesteads. 
In December 2003, Zanele and I took the group from Amatikwe for a week-long workshop on the south coast of KwaZulu-Natal where, through my facilitation, they produced a play about their experience of life in their home area (see Chapter Four). In November 2004, at the end of the project with LOT, Zanele and I convened a last workshop, in which we once more took them to a conference centre away from their homes. Here I facilitated group discussions around themes that had emerged in previous interviews, and through the course of our ongoing interaction, about which I wanted to know more.

Tabulating my research with interlocutors, I gathered data from interacting with individuals in eighteen neighbourhoods in Okhahlamba made up of five in African freehold settlements, two in the towns of Bergville and Winterton respectively, and eleven in the Ngwane and Zizi land areas. I visited a nineteenth neighbourhood outside the sub-district, where I followed a home-based carer to her married home. As intimated in the introductory chapter of the book, all in-depth interviews with individuals were conducted in isiZulu and recorded on a tape recorder with the permission of each person concerned. Altogether, 26 90-minute unstructured interviews were recorded with home-based carers; sixteen with izangoma and izinyanga (diviners and herbalists); 55 with the young people who were members of LOT, together with their guardians; three with two poets; five with VCT personnel at Emmaus Hospital and at two clinics in the region; one with a retired nurse who had trained the homebased carers in palliative care before launching the home-based care programme; one with a doctor at Emmaus Hospital; and eight with people who were on antiretroviral therapy. In nine cases, support-group meetings were recorded, transcribed and translated. Altogether, I24 extended in-depth interviews were carried out in the region. The interviews were augmented with ongoing contact with the people concerned and with careful notes on developments within their lives over time.

Transcriptions of the tapes in isiZulu were translated into English, with important phrases retained in peoples' mother tongue. Xolisile Zondo, a young woman from the Bergville area who had completed some years of university training, for the most part, admirably transcribed and translated them. I read all of her translations as she completed them, checking that they remained close to the spirit of local Zulu expression.

The individuals I came to know and the groups of people to whom I was introduced were all aware that I aimed to write of the experience of people living with, or alongside, HIV and AIDS. Phumzile, Zanele and myself introduced the research by explaining that I would write about the circumstances of people living with HIV and AIDS in their home area, so as to share their accounts and concerns with South Africa and a wider global audience in ways that would reflect the local cultural repertoires that were brought to bear on the ways in which people came to meet the illness. 



\section{Acronyms}

\begin{tabular}{|c|c|}
\hline AIDS & Acquired Immune Deficiency Syndrome \\
\hline ANC & African National Congress \\
\hline ARV & Antiretroviral \\
\hline ATM & Automatic Teller Machine \\
\hline $\mathrm{CBO}$ & Community Based Organisation \\
\hline $\mathrm{CD}_{4}$ & $\begin{array}{l}\text { (Cluster of differentiation) } 4 \text {, refers to a glycoprotein on } \\
\text { the surface of various cells in the body, including the T } \\
\text { helper and regulatory cells. The CD } 4 \text { count test is used to } \\
\text { assess the relative strength or weakness of a person's im- } \\
\text { mune system in undergoing HIV and AIDS. }\end{array}$ \\
\hline COSATU & Congress of South African Trade Unions \\
\hline CSG & Child Support Grant \\
\hline HEARD & Health, Economics and HIV and AIDS Research Division \\
\hline HIV & Human Immunodeficiency Virus \\
\hline HIVAN & Centre for HIV and AIDS Networking \\
\hline ICU & Industrial and Commercial worker's Union \\
\hline ID & Identity Document \\
\hline IES & Ikhungusethu Environmental Services \\
\hline IFP & Ikhatha Freedom Party \\
\hline KIDS & The KwaZulu-Natal Income Dynamics Study \\
\hline LOT & Leaders of Tomorrow \\
\hline $\mathrm{NIH}$ & National Institutes of Health \\
\hline NGO & Non Governmental Organisation \\
\hline $\mathrm{OM}$ & Okhahlamba Municipality \\
\hline OVC & Orphans and Vulnerable Children \\
\hline PEPFAR & $\begin{array}{l}\text { The United States President's Emergency Fund for AIDS } \\
\text { Relief }\end{array}$ \\
\hline SAIRR & South African Institute of Race Relations \\
\hline SABC & South African Broadcasting Company \\
\hline SAC & South African Census \\
\hline SADHS & South African Department of Health Statistics \\
\hline SADOH & South African Department of Health \\
\hline SPP & Surplus People's Project \\
\hline SSA & Statistics South Africa \\
\hline TAC & Treatment Action Campaign \\
\hline TDCSP & uThukela District Child Survival Project \\
\hline UNAIDS & Joint United Nations Programme on HIV and AIDS \\
\hline UNDP & United Nations Development Programme \\
\hline UNICEF & United Nations Children's Fund \\
\hline VCT & Voluntary Counselling and Testing \\
\hline WISER & Wits Institute of Social and Economic Research \\
\hline
\end{tabular}





\section{Glossary}

As sentences, poetry and substantial phrases in isiZulu are accompanied by translation in the main body of the text, I list here only single words and short phrases in isiZulu inserted into the text.

\section{Nouns with the prefix 'aba'('abe')}

$\begin{array}{ll}\text { (abe)lusi bezulu } & \text { heaven-herds (those who can control storms) } \\ \text { (abe)lungu } & \text { white people } \\ \text { dala asebalala } & \text { old people who are sleeping (the ancestral shades) } \\ \text { hambile } & \text { those who have gone, who have died } \\ \text { kwekazi } & \text { used by a groom to refer to the bride's mother together } \\ & \text { with other mature female relatives in the bride's family } \\ \text { lele } & \text { those who are sleeping (ancestral shades) } \\ \text { lingane } & \text { used by a bride to refer to the groom's mature relatives } \\ \text { ngaseko } & \text { those who are not here (ancestral shades) } \\ \text { phansi } & \text { those from below (ancestral shades) }\end{array}$

Nouns with the prefix 'ama'

$\begin{array}{ll}\text { dlozi } & \text { spirits (ancestral shades) } \\ \text { khambi } & \text { medicines; sometimes used to refer to ARVs } \\ \text { khambi esintu } & \text { curative herbs of humankind (herbal medicines) } \\ \text { khambi okugeza } & \text { medicines used to wash oneself } \\ \text { si } & \text { sour milk } \\ \text { sondo ezimkomo } & \text { hooves of the cattle, referring to a set of brooms given in } \\ & \text { marriage by a new mother-in-law to her daughter-in-law } \\ \text { sotsha omzimba } & \text { soldiers of the body (immune system) } \\ \text { thambo } & \text { bones } \\ \text { thumbu } & \text { boils } \\ \text { tshitshi } & \text { prepubescent young girls }\end{array}$

Nouns with the prefix ' $i$ '

$\begin{array}{ll}\text { gciwane } & \text { HI virus (derived from the word for germ) } \\ \text { khanda } & \text { head } \\ \text { lobolo } & \text { bridewealth } \\ \text { mpepho } & \text { Helichrysum miconiaefolium (herb burnt to summon the } \\ & \text { ancestoral shades) } \\ \text { ngculaza } & \text { AIDS } \\ \text { ngoma yobusuku } & \begin{array}{l}\text { night song referring to the singing and dance genre, isi- } \\ \text { cathamiya }\end{array}\end{array}$


nkehli

nkomoyomgano

nkunzi

noni

nsangu

ntaba

nyama

nyanga, pl. izinyanga

nyoni yezulu

sangoma esinabalozi

sangoma, pl. izangoma diviner/s

thuna

grave

thwasa, pl. amathwasa trainee diviner/s

xhiba groom's home

bull

marijuana

mountain

flesh

herbalist/s leader (in this case referring to a leader of a group of girls in courting rituals)

marriage beast, head of cattle accompanying bride to

local term used to connote a jelly-like substance said to induce faithfulness in men

bird of the heavens (lightning bird)

diviner with whistling spirits

house made of grass ('beehive hut')

Nouns with the prefix 'im'

beleko

goat skin to carry a child on the back. Also refers to the ritual introducing the child to his or her ancestral shades.

bogodo nesisekelo grinding stone and foundation stone (metaphors for a woman as anchor of a rural home)

Nouns with the prefix 'in'

kosazane term of respect used to refer to an unmarried woman

kosi king, chief

Nouns with the prefix 'isi'

$\begin{array}{ll}\text { bindi } & \text { liver, used here to connote courage as in, 'she has a liver' } \\ \text { cathamiya } & \text { singing and dance genre meaning to tread softly like a cat } \\ \text { fuba } & \text { chest } \\ \text { hasho } & \text { discrete phrase called out to mimic particular rhythmic } \\ & \text { qualities of a dancer's steps } \\ \text { lilo } & \text { mourning ceremony from the word lila, to weep } \\ \text { shebo } & \text { relish, vegetables } \\ \text { su } & \text { stomach } \\ \text { qenge } & \text { wooden meat platter }\end{array}$

Nouns with the prefix 'izi'

celo

dingo ezincane

gubhu

guli zami requests made for gifts from the bride's family to the groom's family

small necessities

plastic bottles of herbal medicine

my ill ones, my patients 


$\begin{array}{ll}\begin{array}{ll}\text { mpahla } \\ \text { ngcosho }\end{array} & \begin{array}{l}\text { things } \\ \text { pickings, referring to small wedding gifts from the bride } \\ \text { to the groom's family }\end{array} \\ \text { ntandane } & \text { orphans } \\ \text { nyawo } & \text { feet } \\ \text { phonso } & \text { love charms } \\ \text { vovo } & \text { beer strainers }\end{array}$

Nouns with the prefix 'o'

dokotela bio-medical doctors

Nouns with the prefix ' $u$ '

\begin{tabular}{|c|c|}
\hline$b a b a$ & father \\
\hline babomkhulu & grandfather \\
\hline buntu & $\begin{array}{l}\text { humanity (personhood derived from one's relationship } \\
\text { with others) }\end{array}$ \\
\hline daka & mud used to smear homestead walls \\
\hline hulumeni & the government \\
\hline khamba & clay pot \\
\hline kwelapha kwesintu & $\begin{array}{l}\text { ways of healing humanity, humankind ('traditional' medi- } \\
\text { cines) }\end{array}$ \\
\hline makoti & bride \\
\hline malume & mother's brother \\
\hline malumekazi & mother's brother's wife \\
\hline mama & mother \\
\hline mamezala & mother-in-law \\
\hline mamkhulu & grandmother \\
\hline mamncane & $\begin{array}{l}\text { little mother, can refer to mother's younger sister or } \\
\text { father's younger wife }\end{array}$ \\
\hline mkwenyana & bridegroom \\
\hline moya & air, breath \\
\hline Mvelingqangi & God (literally, the first to appear) \\
\hline phuthu & maize porridge \\
\hline qwembe & wooden platter \\
\hline
\end{tabular}

Nouns with the prefix ' $u b u$ '

$\begin{array}{ll}\text { hlobo obuhle } & \text { good friendship } \\ \text { thakathi } & \text { witchcraft }\end{array}$

Nouns with the prefix 'um'

abo ceremony in which gifts (clothing and household goods)

are given by a bride's family to the groom's family

embeso ceremony in which gifts (clothing and household goods)

fula river 


\begin{tabular}{|c|c|}
\hline khongi & $\begin{array}{l}\text { mediator in marriage negotiations sent by groom's family } \\
\text { to girl's family }\end{array}$ \\
\hline lahlankosi & $\begin{array}{l}\text { branch of the Buffeldooring tree (Ziziphus mucronata) } \\
\text { used to guide spirits of the dead to their homes }\end{array}$ \\
\hline nakabaphathi & $\begin{array}{l}\text { young child who requires special care, here applied to } \\
\text { adults (patient) }\end{array}$ \\
\hline phako & food for the road \\
\hline phrofethi & a prophet \\
\hline phupe wesangoma & a degenerate diviner \\
\hline samo & $\begin{array}{l}\text { raised platform in a home, where offerings are made to } \\
\text { ancestral shades }\end{array}$ \\
\hline sebenzi & ritual ceremony (literally meaning work) \\
\hline sebenzi wedlozi & work of the ancestors \\
\hline sebenzi wocansi & work of the mat (sexual intercourse) \\
\hline shangazo & ARVs \\
\hline zala & cross-cousin \\
\hline
\end{tabular}

Nouns with prefix 'umu'

thi wokuncinda medicine licked from a pottery shard

Verbs prefaced by 'uku', meaning to:

bhebhetheke

bhimba

$c a b a$

chatha

gana

gquma

hlanza

hlonipha

hlowa kwezintombi

hudela

naka

nyanya

patha

phalaza

qoma

sisela

soma

teta

thinta

thwala

zimela to spread fiercely like a fire

to make disharmonious sounds while singing

to make incisions on the body into which medicines are rubbed

to empty intestines through an enema

to marry or elope without bridewealth having been given

to steam oneself with medicines

to use emetics

to respect

to test girls for virginity

to have diarrhoea

to pay attention (used in the form of nakisisa, paying attention)

to recoil in disgust

to carry, to treat, to care for

to vomit

to chose a lover on the part of a girl

to care for another's animals in return for any offspring they may have

to have thigh sex (non-penetrative sex)

to carry an infant on the back, used here to refer to carrying an adult as if they were an infant on one's back to touch, to cure, to cause change

to carry off a girl to a man's home (with or without her agreement)

to stand up, used here to mean to support oneself 
zula emgwaqeni to wander the roads (sexually promiscuous)

\title{
Other phrases and terms
}

\author{
Egoli \\ kipitile \\ Johannesburg (the place of gold) \\ Kuyafiwa \\ casual relationship \\ lesisifo \\ There is death. \\ Mashaya Bhuqe \\ this illness (term used most frequently to refer to HIV \\ and AIDS) \\ AIDS) \\ Ngiwusekela wakhe. I am his prop. \\ Qáthatha! \\ onomatopoeia for the sound of arrival \\ Usala 'ngamathambo. You are left with bones.
}





\section{Notes}

\section{Introduction}

I. The expression, 'return of my body', was used by a person I knew who described to me what it was like to experience the return of flesh to his body after having undergone antiretroviral treatment for some time.

2. As of April 2007, small child support grants of RI70 (\$24.28) a month were issued on application to poor children up to the age of fourteen by the South African Welfare Department. The child support grants have more recently been extended to poor children up to the age of eighteen years. The latter grants are relatively easy to obtain compared to the more substantial fostercare grants, for example, that require a visit from a social worker to the family in which the child resides and a court case. Nevertheless, Child Support Grants were dependent at the time on producing the birth certificates of children, documents that are not always obtainable.

3. Didier Fassin spoke of his ethnographic research with people suffering from HIV and AIDS in South Africa at the Life and Death in a Time of AIDS Symposium, held at the Wits Institute of Social and Economic Research (WISER) in October 2004. He asked participants to consider the ways in which the presence of AIDS often galvanised people afflicted with the disease into reordering their lives, into reshaping and often improving their relations with others in the face of death. Such possible strategies that intensified a way of living, a call to life prior to death, were often omitted in the ways in which the disease and its social effects were being written about at the time (personal notes).

4. Achille Mbembe (200I: I46) has explored the proximity of life and death in straightened circumstances in Cameroon where, citing Foucault (I970), he writes that for the vast majority of people, life and death fit 'exactly one against the other, surface to surface, immobilized and as it were reinforced by their reciprocal antagonism'. People living in extreme poverty experience a 'naked' need in which death is near. In relation to contemporary imaginaries is Kinshasa, Filip de Boeck and Marie-Françoise Plissart (2004: 56-8) who also draw on Mbembe, write of the encroachment of the 'second world', the world of the night, of the occult, into the 'first world', the world of the day, claiming that 'the seen and the unseen no longer balance one another'. Nor do they 'produce one another in equal ways'. The second world has come to 'inhabit and has overgrown its opposite'. Consequently, the space of the living has been 'invaded' by the dead. Mbembe (2003) has developed the term 'necropolitics' to charter the ways in which death has entered in uncanny ways into oppressive social worlds.

5. A few references that allude to illness, the body and society include Biehl (2005); Csordas (2002, I999); Kleinman \& Kleinman (I99I); Kleinman (I997, I995, I988); Petryna (2002); Scheper-Hughes (I992); ScheperHughes \& Lock (I987) and Valentine-Daniel (I996). Others have explored these themes in the context of political violence (see, for example, Das et al 200I; Das et al 2000 and Kleinman, Das \& Lock I997). 
6. No appropriate term exists for the locally identified areas in which people live in Okhahlamba. Although 'neighbourhood' conjures up the idea of neighbours living within an area in an urban landscape, the terms 'community', 'locality', 'settlement', 'informal settlement' do not capture people's identification with the areas in which they lived, or their social inter-relations within them. 'Community' is already an overused word, presuming coherence and common interests that do not necessarily exist. 'Locality' at least suggests a terrain to which people relate, which is closer to the ways in which people in Okhahlamba inhabited their varied living spaces. 'Settlement', although appropriate in some ways to the more over-crowded areas in Okhahlamba, such as Dukuza and Zwelisha, cannot be applied to scattered homesteads in some areas. 'Informal settlement' is too closely associated to the shantytowns of urban spaces and cannot encompass the values attached to homesteads and their graves, or their location in relation to one another. I therefore use the word 'neighbourhood' despite its inadequacies, because it suggests the social aspects of living alongside others.

7. Early anthropological literature explored the relationship a mother's brother had with a sister's son in ways that at the time were thought to be particularly exciting within the discipline of social anthropology, in its attempt to form general theories about the structures of kinship in human society (see, for example, Junod I9I2; Radcliffe-Brown I924; Goody I959, and Fortes I969). Later theorists questioned the monolithic ways in which kinship studies assumed universal structures and terms. David Schneider (I984), for example, questioned the notion of kinship related solely to biology, as well as the equivalence or similarity of basic institutions such as marriage across human societies. A more recent revisiting of the mother's brother, sister's son relationship in relation to psychological dispositions, is given by Bloch and Sperber (2006). See also Janet Carsten (2000 ed., 1995) who replaced the notion of kinship with what she called 'relatedness', a notion in sympathy with my own work. See also Sarah Franklin and Susan Mckinnon (200I) for a compilation of seminal works concerning kinship. Although the presumption of certain universalities within kinship studies has long since eroded, the particularities of a relationship of, for example, a mother's brother and sister's son within specific places and in relation to local histories, still informs social life in many parts of the world.

8. João Biehl (2005) in his book, Vita: Life in a Zone of Social Abandonment, has reinvigorated the notion of experience. In relation to Catarina, the main protagonist of his work, he demonstrates the meaningfulness of her record of her experience - the incantationary written fragments of her dictionaries. Other studies, for example, Desjarlais (1997, I994) questioned the idea of experience in relation to similarly marginalized individuals, many of whom were mentally afflicted and who, in his view, 'struggled along' in ways that were antithetical to the construction of experience through continuity, coherence and meaningfulness.

9. Veena Das (2002, 1997, 1990) in relation to the excruciating violence of partition with the inauguration of independent India and Pakistan, writes of silence and the ingestion of suffering that is too dangerous to articulate. Her work has to do with state and 'community' violence, but also the violence of culture, which she explores in relation to unpalatable knowledge and the inadmissibility of certain kinds of pain. She shows how political violence is 
played out on the bodies of women, a form of territorialization, and she examines the consequences of this for subjectivity.

IO. Kalpeni et al (2004) have pointed out the ways in which early models used to predict the scale of the epidemic were cruder than more recent models, and that early figures were often based on inaccurate data.

II. See Eleanor Preston-Whyte (I995) for a well-argued anthropological piece dealing with the importance of understanding the cultural specificities of sexuality and gender inequalities that engage with the constraints of a particular political economy and history in KwaZulu-Natal. She writes of the contribution ethnography may make to intervention programmes dealing with sexual risk. Given the establishment of relationships of trust between researchers in conversation with their interlocutors, she suggests that futures may be imagined together in which the issue of sexual risk is confronted, and in which methods of combating it take into account both gender dynamics and local views on fertility and sex. Other work, dealing with the issue of gender and prevention in KwaZulu-Natal and elsewhere include Hoosen and Collins (200I), Abdool Karim et al (1992b) and Abdool Karim $\&$ Preston-Whyte (I992).

I2. In relation to bewitchment see also Ashforth (2004, 2002, 2000); de Boeck and Plissart (2004); Devisch (200I); Ferme (200I); Moore and Sanders (200I); and Niehaus with Mohala and Shokaneo (2002a). In relation to southern Cameroon, for example, Achille Mbembe (200I: I45) alludes to the magic and bewitchment that fold into the everyday, rendering reality multiplicitous. Mbembe describes how the invisible does not constitute the other side of the visible in terms of an opposing reality. "The reverse of the world', the 'unseen', the secret, is rather part of the visible, and the inseparability of the being and non-being of persons and things. Jean and John Comaroff (I999) situate the occult within the context of jarring global and national inequalities within South Africa.

I3. Through examining old ethnographies, Peter Delius and Clive Glaser (2002) have given an historical overview of sexual norms in southern Africa.

I4. Within the city of Durban, Preston-Whyte et al (2000: 186-87) describe a broad range of 'survival sex' stretching from 'commercial sex' as it is narrowly defined, to 'a much more informal and essentially ambiguous category of action for which the term "commercial" is not appropriate'. As such, the work begins to describe the complexities of sustaining life in a context of poverty through particular sexual relations and suggests a reality not unlike that described by Mark Hunter, as summarized above.

I5. The Children's Bill (Act No38 of 2005) passed in parliament by the National Assembly on I July 2005, and thereafter considered by the National Council of Provinces, came into effect on I July 2007. The Bill outlaws the practice of virginity-testing for girls under the age of sixteen, indicating an emerging clash between the realm of constitutional rights - in particular the right to bodily integrity - and local practices. See Children's Institute (2005) for a policy discussion on the subject in which some of these issues are raised. See also the following newspaper reports: Cape Times, Io September 2007; Daily News, 4 July 2007, 25 August 2007; Mail \& Guardian, 23 June 2005; Mercury, 5 September 2007. Responses in the press suggest that the state will not be able to put an end to the wide range of activities associated with virginity-testing. 
I6. In relation to masculinities in South Africa, see also Reid and Walker (2005), Niehaus (2002b) and Catherine Campbell (I997). Leclerc-Madlala (2002) writes on sexuality and gender inequalities, in particular the construction of women in many parts of KwaZulu-Natal as carriers of pollution. She shows how local conceptions to do with gendered bodies reinforce the notion that women spread illness because of the particularities of their bodies in being 'open' and in the necessity of regularly shedding themselves of pollution through menstruation. In contrast, men in the particularities of their bodily formation are perceived as being 'closed' to pollution. They are nevertheless victims of women's pollution. Notions such as these pre-empt too close an examination of male sexuality and practise.

I7. Nonzizwe Madlala-Routledge was fired by the state president in early August 2007. See the following small sample of newspaper articles in which the public's response to the dismissal is made clear: Daily News, 9 August 2007; Sunday Independent, 2 September 2007; Mail \& Guardian on Line, IO August 2007, I4 August 2007.

I8. See Stoller (I995) for an ethnographic account of the embodiment of colonial memories. Stoller's work shows the ways in which an oppressive colonial history continues to haunt post colonial social worlds in enacted ways.

I9. Jacques Rancière (2004) has returned the notion of aesthetics to the analysis of social and political life. He shows how the particularity of aesthetic experience is intertwined with ways of life and everyday practice and yet exceeds it. Aesthetic appropriations and reflections upon life therefore hold within them the possibilities for critique and political action.

20. It is not surprising that Matiwane's ihubo (regimental song), created on his people's peripatetic and combative journeys, became: 'Sibang' inkomo nje, sibang' ilizwe’ (We strive for cattle only and for land) (Msebenzi I938: 20).

2I. Theophilus Shepstone, who from 1845 to 1876 was at first 'Diplomatic Agent to the Native Tribes' and later 'Secretary for Native Affairs' in the imperial government, devised the strategy of indirect rule. See Etherington (I989) for an account of Shepstone's divide and rule policy.

22. See Wright (I97I) for a detailed account of San cattle raids into Natal. Wright and Mazel (2007: 94) refer to groups of San and Phuthi mounted on horseback and armed with guns, who conducted successful cattle raids across the western borders of Natal during the I860s and 70 s.

23. See Colin Bundy's (I979) work for an overview of the rise and fall of an African peasant class in South Africa.

24. See Shula Marks (I970) for a thorough account of I906 tax disturbances.

25. Shula Marks (I986) has written an account of Champion's leadership of the ICU in Natal and given reasons for its eventual demise. Between I927 and I928 at the peak of its organization, there were over a I00,000 ICU members across racial groups within South Africa (Beck 2000: II8).

\section{The Vertiginous Body and Social Metamorphosis}

I. Recent theoretical approaches to the body have underscored that it is not a fixed entity 'subject to empirical rules of biological science, existing prior to the mutability and flux of cultural change' (Csordas [I994] 2000: I). In other 
words, the body has a history, as Foucault and others have argued (Foucault I977, 1978).

2. Nadia Seremetakis (I996: 23-43) writes of the embodied ways of learning in rural Greece between grandmothers and their grandchildren, in a grandmother's mastication of bread for a child, and in the naming of their body parts as if they were their own. She suggests that it is in these sensual repertoires that children come to know a particular sociality, conjoining the generations and giving rise to historical consciousness.

3. In the Phenomenology of Perception, Maurice Merleau-Ponty (2000: I50) writes: 'My body is made of the same flesh as the world'. He insists that knowledge of the world issues from our embodied perceptions, enabling us to encompass objects only through overcoming the subject/object divide.

4. The bulk of writing on HIV and AIDS in South Africa has insisted on distancing itself from the immediacy of individual suffering. Writing has predicted various outcomes for society: the projection of the scale of death in terms of numbers, further effects on the economy of the country, on governance, and the socialization of children etc. (see, for example, Bray 2003; Mattes \& Manning 2003; Nattrass 2004; Whiteside \& Sunter 2000). Predicting outcomes is a legitimate sociological pursuit, yet has a distancing effect in terms of language use and in terms of the framing of time.

5. Nkosinathi's mother's anger at her son not having sent home money from the city is understandable in a context of extreme poverty and in which on his return, she would have to support him and other dependents on a meagre state pension.

6. In the late I990s, 77 home-based caregivers were trained to assist sick people in their homesteads in eleven out of thirteen wards in Okhahlamba. Through the help of an NGO, the Thukela District Child Survival Project (TDCSP) and the Department of Health provided training for volunteers to assist a variety of patients, in particular those terminally ill with AIDS.

7. In Zulu indigenous medicine, important practices of healing involve ukuphalaza (induced vomiting) and ukuhlanza (emetics) (Bergland I976: 328; Ngubane 1977: I07-I08). Healing methods within this framework associate these practices with a cleansing out of the body's pollution, a pollution often induced through ubuthakathi (witchcraft). As many people afflicted with HIV and AIDS in Okhahlamba visited different kinds of healers, a large number underwent treatment that induced vomiting or the expulsion of the body's fluids through other means. In Zinhle's view, people who took the medicines of izangoma died more quickly than those who frequented the hospital and the clinics.

8. The idea of being injected with the virus powerfully demonstrated fears around its acquisition, as well as distrust of medical institutions and their technologies. Interestingly enough, several cases to do with the allegation that a person had been deliberately injected with the virus appeared in the South African Press. See The Witness, 6 February 2004: 3, local and national news. According to this newspaper report, a woman was abducted by a group of men after having complained about barking dogs. The men stopped the car and told the woman that they would give her AIDS. They injected her with something, leaving her at the roadside. See also The Witness, 20 January 2004: 3, local and national news. The article refers to a 
nurse who was arrested on charges of injecting her stepson with blood containing the HIV virus.

9. Many people in Okhahlamba thought that Ladysmith Hospital was better than Emmaus Hospital.

Io. Impepho is a cleansing herb associated with the shades because it and its flowers do not wither when picked. In analogous ways, shades never die. When harvesting the plant, diviners approach it with respect, asking it to agree to be picked for the purposes of communicating with the ancestors (Bergland, I976: II3; Bryant I905: 496; Colenso ı855: 466; Doke \& Vilakazi I948: 658).

II. Alphonso Lingus (2000: 25-39) explores the idea of both the body's permeability and the ways in which we learn broadening pleasures through touching and coming to know, in such non-violent ways, the particularities of creatures not of our own species.

I2. Julia Kristeva (I982: 3) has written in a telling way about seepage in the body and its connection with death. She writes: 'These body fluids, this defilement, this shit are what life withstands, hardly, and with difficulty, on the part of death. There, I am at the border of my condition as a living being. My body extricates itself, as being alive, from that border. Such waste drops so that I might live, until from loss to loss, nothing remains in me and my entire body falls beyond the limit - cadere, cadaver'.

I3. See Bourdieu I977; Csordas I994; Douglas [I970] I982, [1966] I980; Durkheim I951; Geertz I974; Hertz I960; Lévi-Strauss I967; Lock \& ScheperHughes, I987; Scheper-Hughes I992; V. Turner I969; T. Turner I980 and Van Gennep ig6o.

I4. The notion of the abject I am using is derived both from the work of Mary Douglas (I960) and that of Julia Kristeva (I982).

I5. Luce Irigaray (I985) shows how the fluid and the indeterminancy of fluids has not so much to do with their intrinsic qualities but with their cultural unrepresentability within prevailing philosophical models of ontology.

I6. Within a context of national liberation and constitutional freedoms, together with a widening visibility of sexuality in public discourse, Achille Mbembe (Mail a Guardian, II-I7 July 2003: 23) has written of the irony of the restrictions on current sexual happiness. These restrictions have to do with 'our own bodily constitution, its vulnerability to overwhelming and merciless forces of destruction, chief among which is HIV/Aids'.

I7. In relation to trying to solidify rural homesteads in peasant communities in Zululand, Hylton White (2002: 457), drawing on the ideas of Ernest Bloch (I935), has written of the evocation of the past as custom in times of crisis. The 'ghost of the old', whether real or imaginary, is 'conjured up' within the new. Spectres of the old are brought to bear on the present to render it coherent, if only for a while. Economic and political crises that have to do with global forces and the increasing marginalization of the poor are felt in embodied ways within families. These conflicts are played out in the particular ways in which individuals become possessed and consequently ill from the interference of shades - shades who are unhappy about past social, and in particular familial misdemeanours.

I8. Many explanations for the advent of HIV and AIDS in Okhahlamba revolved around the idea that whites had deliberately infected black people with the virus to finish them off once and for all. Reasoning behind this idea had to 
do with deaths having become more prevalent after the I994 elections. Whites were therefore killing black people because Africans now have the vote. In some instances, in shops owned by white people where food is sold to poor black people, it was said that the food was infected deliberately with the virus for the same reasons. These notions may be fruitfully analysed, for example, in relation to Bloch's (I935) idea of the spectral haunting of the figure of the past in the present. See Richard Eves (2003).

I9. The space for mutual recriminations in a relationship of intimacy, where both partners are HIV-positive is potentially vast. Neither is recrimination confined within a sexual relationship. Relatives begin to blame one another. For example, in a patriarchal setting, a man's mother often blames her son's girlfriend for his demise.

20. Robert Thornton (2003) in a paper entitled 'Flows of "sexual substance" and representation of the body in South Africa' draws attention to both the healing and pathogenic potential of the flow of sexual fluids between men and women in the symbolic dimensions of southern African sexuality. He suggests the importance of sexual flow through time in generational flows of semen between ancestors and the living in relation to procreation. In addition, he suggests the ways in which sexual exchange between lovers creates contemporaneous social networks associated ideally with material exchange. Sexual flow becomes polluting in particular circumstances, for example in relation to mourning. In this instance, the importance of sexual flow in shaping identities and relationships of obligation, as well as in linking the shades with the living, suggests positive attributes in relation to fluidity and the creation of identity through relationship.

2I. Luce Irigaray (1985) is responsible for highlighting the conversion from a fluid to a solid in the case of seminal fluid. It is of interest that the ideal to do with women's comportment during the sexual act amongst many Zulu speakers in Okhahlamba implies the control of female fluids during penetrative sex. Dry sex, meaning a dry vagina during sexual intercourse, is upheld as appropriate, and many women use herbal substances to promote the dryness of their vaginas during sexual intercourse.

22. The use of love charms (iziphonso) is nothing new. Young men are also renowned for using a particularly potent medicine on girls with whom they seek a sexual relationship and who are reluctant to comply. Ngubane (I977: 3I) suggests that while it is legitimate for young men to use love charms to win the hearts of the girls they court, this is not the case for girls. Wives are regarded as selfish in using love charms on their husbands (ibid).

23. Untreated sexually transmitted illnesses have in some cases resulted in infections in women's wombs that have led to an infestation of worms. For example, a home-based carer at a support group meeting at the Mazizini Clinic described in detail how a patient of hers suffered from an infestation of worms.

\section{Mortality and the Ethics of Ethnographic Research}

I. The reason AIDS is not referred to directly in spoken isiZulu is that as a devastating illness, it has taken on the attributes of a powerful presence or personage. It is therefore treated with respect and avoidance, as are other 
social relationships in which differences of status are manifest. In naming AIDS directly one would be calling upon oneself the 'attention' of the illness. For the intricacies of certain forms of avoidance in spoken isiZulu, as well as in relation to the disease, see Dowling, 2004, I988.

2. See Hunter I979:340.

3. In anthropological writings, Johannes Fabian (1983) echoes some of the characteristics of responsibility between two persons in relationship as described by Levinas in writing of the ideal of an 'I and Thou' relationship between coeval researchers and interlocutors in ethnographic research, a relationship said to facilitate mutual respect and influence; a formulation taken from the work of Martin Buber (I996). For an account of how Levinas' thought differs from that of Buber's in relation to the latter's coeval formulation of the I/Thou relationship, see Levinas 200I: 72-73.

4. Home-based carers reported three stories concerning patients in which neighbours were prevented from visiting them by the patients' relatives who claimed that they were somewhere else when visitors came to call.

5. See Edwin Cameron's (2005: 42-74) book for an examination of the ways those afflicted with AIDS sometimes contribute to their own isolation because of internalized shame. See Austin 1962; Butler i997; Matsuda et al, I993 for theoretical accounts of the pernicious effects of speech.

6 . For an example of the way in which language reaches beyond already established codes, see Maurice Merleau-Ponty I974: 36-94, I964: 84-97.

7. Much has been written about the South African state's response to the HIV and AIDS epidemic. See Posel (2004) and Cameron (2005) for particularly insightful contributions.

8. The home-based care kit available at the local clinic contained aqueous cream to soothe dry skin; two disinfectant sprays to clean the floor and room in which the ill person lay; cotton wool and Betadine antiseptic for swabbing wounds; elastoplasts; gauze; gloves to protect the carer from direct contact with faeces and body fluids; a mask to shield the carer from the smell of decay; a rubbish bag in which to place discarded swabs; an apron to protect the carer's clothes; napkins to contain the ill person's body waste; gentian violet to ease sores in a person's mouth; antiseptic soap to wash the hands of the carer and the body of the afflicted.

9. See previous chapter.

Io. Placing critically ill patients on a drip was common practice at the local clinic and seemed to revive patients who had lost much of their body fluid through diarrhoea.

II. The HIV virus destroys a type of white blood cell in the body known as CD4 + cells. CD4 or helper T cells defend the body against disease. As the virus destroys more and more $\mathrm{CD}_{4}$ cells, so the immune system becomes weaker and weaker. When a $\mathrm{CD}_{4}$ count is taken - a blood test administered to gauge the number of $\mathrm{CD}_{4}$ cells remaining in the body - and the results are below 200, the body's immune system is severely compromised. It is at this point that antiretroviral therapy was advised. 


\section{Children and Youth in Pursuit of Care}

I. Although the popular conception of an orphan issuing from the 'western' world is someone who has lost both biological parents, in global forums, orphans are defined as those under eighteen who have lost a mother, a father, or both biological parents.

2. When poor children are characterized as passive victims, negative stereotypes adhere to them. For example, Nancy Scheper-Hughes and Carolyn Sargent (I998: 3) show how poor children, through being relegated to a place of marginality and hence cast as passive recipients of national or global policies, come to be described as the 'quintessential supernumery other'.

3. Literature that has contributed to an appreciation of children as active agents in creating social worlds include, for example, Sharon Stephens (I995), Alison James and Alan Prout (I990) and James, Jenks and Prout (I998). See Reynolds (I987) and Nieuwenhuys (I994), who have produced seminal studies to do with children's contribution to the world of work. See Ed Cairns (1996), Robert Coles (I986), and Reynolds (2000, I995a, I995b) for children's contribution to political life. See Opie and Opie (1969, I977) and Goldman (I998) for children's playful use and creation of language and word games. On young people's creation of youth culture, see Amit-Talai and Wulff (1995).

4. See, for example, Barnett and Whiteside (2002: 2II); Coombe (2000: 2); Hunter (I990); Marcus (I999); Schonteich (I999, 200I); and UNICEF (2003: 49).

5. In relation to studies to do with orphanhood in Botswana, Zimbabwe and Uganda see, for example, Drew, Foster and Chitima, I996; Aspaas, I999; Basaza \& Kaija, 2002.

6. Jeremy Seekings (1996, 1995) has thoroughly explored the negative images of youth prevalent in media at the time. See also Njabulo Ndebele (I995).

7. Connolly and Ennew (I996) provide a critique of alarmist predictions of large increases in the numbers of street children in the world. See also Ennew (I994) with regard to the importance of examining the social networks of street children. Ennew (200I) also outlines the inadequacies of the ways in which children are defined as orphans in Sub-Saharan Africa and South East Asia.

8. For an exploration of the long-term attrition of multiple deaths within the context of the AIDS pandemic, particularly with regard to the layering of mourning, see Chapter Two.

9. UNICEF's report Africa's Orphaned Generations (2003) claimed that there were more than 34 million orphans in Sub-Saharan Africa, with II million of these being orphaned through AIDS. UNAIDS (2004), over the same region, suggested that 43 million children under eighteen had experienced the death of one or both parents by 2003. In South Africa, the Actuarial Society of Southern Africa (ASSA 2002) suggested that by July 2004 there would be 2.9 million children under the age of eighteen who would have lost their mother or father, and that 250,000 children under eighteen would have lost both parents.

IO. See Daniel (2003: 2-3) for an exploration of silence in relation to the social pain of being an AIDS orphan in Botswana. The author writes of the 'hidden 
wounds' that AIDS orphans bear because they are unable to speak of their pain in a context of social marginalization and stigma.

II. See for example, Bruno Bettelheim's (1978) The Uses of Enchantment: The Meaning and Importance of Fairy Tales.

I2. See the work of Filip de Boeck (1998) for an exploration of multiplicitous worlds in which the living and the dead interconnect in Zaire, as well as an appreciation of the seminal roles young people play in economic pursuits and the creation of meaning. See also de Boeck and Honwana (2004).

I3. It is interesting to note that in the whole of Okhahlamba - a region inhabited by approximately I50,000 people - the only orphanage set up by a church group in the small rural town of Winterton had three small children living there from March 2003 to November 2004. It was generally my experience that orphaned children were accommodated by relatives, often grandparents. And where no relatives were forthcoming, they were often taken in by neighbours.

I4. The standard of local education was extremely poor. Very few young people educated in that environment reaped the benefit of education in finding work once they had completed matriculation.

I5. Umdedelele is not the real name of the mountain under which Thulani and Vusi lived.

I6. Sisa and sisela are both Zulu verbs meaning 'to give out stock on loan'. See Dent and Nyembezi (1969: 485).

I7. One young man whom I knew in a neighbouring community shot himself because of the number of AIDS deaths in his family. He had planned to shoot his sister, whom he did not want to live a life of suffering, but not being able to find her, turned the gun on himself.

I8. This is a playful 'tongue in cheek' view of anthropological pursuits from the perspective of an interlocutor.

I9. See Tessa Dowling (2004) for an interesting look at patterns of speech avoidance in relation to serious illness, including HIV and AIDS. Other works examining the practice of ukuhlonipha include Dowling (I988), Findlayson (I995) and Mncube (I949).

20. The Child Support Grant is a relatively easily-obtained social grant for children. In terms of the law, the current caregiver must apply for the grant on behalf of the child. At the time the research was conducted, the grant was a monthly payment of Ri7o (\$25) granted to children up until the age of fourteen. More recently, the state has extended the grant for poor children up until the age of eighteen.

2I. The name, Scorpions, was 'borrowed' from a then existing state anti-corruption unit that shared the same name. The state unit was later dissolved by the president.

22. For an ethnographic study of children's active creation of culture, see Goldman (I998). He describes children's narrative expertize, pointing out their capacity for both mirroring adult society and creating culture in their own right. 


\section{Healers Negotiating the Local and the Global}

I. For an account of the ways in which people describe the scale of deaths due to AIDS in parts of Okhahlamba, see Chapter Two. See The Sunday Independent, 4 December 2005: 2.

2. Bergland (I976: I85-I86) explains that the term 'inyanga' denotes someone who is skilled in a craft or profession. In its everyday usage, the term refers to a diviner/ herbalist of some sort and is often used for a male diviner.

3. 'Isangoma' is a general term for a diviner (see Bergland i976: i86). Harriet Ngubane (1977: 3) distinguishes between an isangoma and inyanga, saying that it is predominantly the former who has the ability to divine and the latter who is involved in the dispensing of herbal medicines.

4. An in-depth exploration of the importance of maintaining bodily coherence and the fear accompanying a failure to do so in the context of HIV and AIDS in Okhahlamba is presented in Chapter One.

5. The policy of indirect rule through the manipulation of chiefs was a wellknown English colonial policy. With regard to the policy in relation to Zuluspeaking people see, for example, Guy (200I: 35, 356-7, 360-I).

6. Under apartheid legislation, it was compulsory for all Africans to carry passbooks (forms of identification) at all times. The documents formed part of influx control regulations that sought to bar most Africans from permanent residence in cities, whilst ensuring access to their labour.

7. See The Witness, 'Chiefly dispute will soon be over', 24 February 2005. The chieftaincy of the Ngwane has long been disputed, with one part of the Hlongwane family insisting that they are not historically affiliated to the amaZulu. Part of the ruling family largely supports the African National Congress (ANC), and the other, the Inkatha Freedom Party (IFP).

8. Note that these conflicts refer to both clashes between migrant hostel-dwellers, largely IFP supporters, and urban dwellers in the I980s and early I990s, as well as to conflicts between the apartheid state and the majority of South Africans.

9. For a detailed account of the inyoni yezulu and of the abelusi bezulu, see Bergland (1976: 37-42).

Io. 'Ithwasa' is derived from the idiom ukuthwasa, or 'coming out afresh after a temporary absence or disappearance'. It usually refers to the reappearance of the moon and to the seasons of the year. With reference to the calling of healer, or diviner, ithwasa refers to a person who has completed their training as a diviner and is ready to return to society to practise as a diviner (see Bergland, I976: 162 and Krige, I936: 307ff).

II. Woodstock Dam was built in I979, necessitating the removal of people living in the vicinity of the site. Its construction was negotiated by a steering committee made up of local chiefs and other community representatives, together with the state. However, this coincided with conflict among the Ngwane around support for the then chief, Tshanibezwe Hlongwane, who was subsequently sent into 'exile' in another part of KwaZulu-Natal.

I2. uMvelingqangi is made up of the word 'vela', to appear, and the word 'nqang', meaning the first and origin (see Bergland I976: 34; Bryant I905: 397; Callaway I870: 7-9; Doke \& Vilakazi I948: 517; Gardiner I836: I78 and Leslie I875: 207). 
I3. Broad Reach Healthcare Programme is an American-based anti-retroviral rollout programme supported by the President's Emergency Fund for Aid Relief (PEPFAR). The model relies on linking private doctors, community networks and organizations, and a small specialized team of Broad Reach administrators to create access to medication and care. Once established, its programmes are taken over by government structures. (See Broad Reach Healthcare Programme, 2005.)

I4. On the 7 th of December 2005, when Ntuthuko and Nonhlanhla's interviews were conducted, there were approximately 70 people taking ARVs in the Broad Reach Programme, and 330 people (including 22 children) taking ARVs from Emmaus Hospital (verbal communication with Phumzile Ndlovu with regard to Broad Reach, and with Dr Bernhard Gaede with regard to Emmaus Hospital).

I5. The Child Support Grant emerged out of a host of investigative processes including the formulation of a Constitution for a democratic South Africa, the Truth and Reconciliation Commission, and the concerted intervention of academics. In I996, Francie Lund headed the Commission for Children and Family Support that in part sought to reformulate the State Maintenance Grant (SMG) for the benefit of all poor children (Lund, 2007). The State Maintenance Grant had been given out by the apartheid state to predominantly white and coloured population groupings, to the general exclusion of Africans.

I6. The phrase 'grinding stones' refers to married women and is taken from a poem by Roman Khumalo, the poet. See Chapter Two.

I7. Some elaborate courting rituals are still enacted in some of the neighbourhoods of the Ngwane.

I8. Many HIV positive people whom I knew in Okhahlamba made their way through diverse healing possibilities in their quest for healing: Zulu medicine and divination, immune boosters, faith healers, and bio-medicine. Some were persuaded to jettison ARV medication, because the 'deep' cause of their illness was attributed to malevolence, or the involvement of ancestral shades. Others happily combined all forms of therapy. Many unequivocally embraced ARV treatment. Perhaps some of the social, cultural and historical tensions I have described contribute to an understanding of the complexity of choosing a treatment regimen. See Liz McGregor's (2005) account of the life and death of popular DJ, Khabzela, where she showed how fault lines between forms of healing were not easily breached. All of the above issues are complicated by a state whose response to the epidemic was at first ambivalent. Others have written how the state's 'Africanist' response to HIV and AIDS, at first stressing 'local solutions' to it, has obscured increasing class divides in South Africa. (See, for example, Robins 2004.)

I9. Ntuthuko is making a reference to 'necklacing', the killing of a person through placing a rubber tyre around their neck, dousing it with petrol, and setting it alight - a fate meted out to some individuals suspected of being apartheid spies or government functionaries within African suburbs during the ig8os.

20. The phrase 'Black Power' is used by Ntuthuko as a general reference to the Soweto uprising of 1976 , in which school children confronted the state, refusing Afrikaans as a medium of instruction in schools. It also refers to the ethos of the times, the black consciousness movement begun by Steve Biko. 
2I. The term 'the Boers' was used to refer generally to white oppressors.

22. Ntuthuko is referring to the Woodstock Dam mentioned in footnote eleven. Its construction was accompanied by community conflict in which several people died. (See the Introduction.)

23. In relation to the above point, Mbembe and Posel (2004: 2) write of the importance of 'critical humanism', and Bhabha and Comaroff (2002) of a 'new cosmopolitanism'. Homi Bhaba (I994: 239-4I) speaks of postcolonial forms of modernity operating as a source of renewal, because they are out of step with the disillusionment that has characterized the nation-state in other parts of the world.

\section{Love in a Time of Adversity}

I. Several factors, including migrancy, declining rates of employment, the financial cost of marriage, and change in gender relations have contributed to the decline of marriage in South Africa and in KwaZulu-Natal over several decades. See, for example, Eleanor Preston-Whyte (1978) for an account of declining marriage in KwaZulu-Natal in the I970s. In relation to women choosing to remain unmarried while bringing up their children, see Eleanor Preston-Whyte (I978) and Mark Hunter (2005: 2I6). According to the South African Census of 200I, only 28 per cent of women in South Africa aged fifteen or older were married. Historically, early patterns of labour migrancy and subsequent apartheid labour laws and influx control regulations separated spouses and children from their parents, laying the foundation for a decline in marriage. In more recent times, changing patterns of employment have both enabled some, mostly urban women and their children, an increasing degree of independence from men, whilst diminishing, in many instances, men's abilities to take on the role of major breadwinners in longterm relationships. In I998, half of all households in the rural areas of South Africa were de facto headed by women (South African Demographic Household Survey (SADHS), I998). In a context of high unemployment, the cost of ilobolo (bridewealth) becomes increasingly difficult to bear. Cohabitation of younger African men and women in their twenties has become more common, with the statistical proportion of marriages increasing with age (SADHS 1998). In relation to the overall impact of increasing unemployment on young men and women in KwaZulu-Natal and the formation of intimate relationships, see Hunter (2007). The overwhelming preponderance of gender-violence has adversely affected sexual relationships. See, for example Jewkes et al (I999), Walker et al (2004) and Wood et al (I998).

2. John Borneman (I996: 2I5), for example, has shown how marriage in much foundational anthropological literature (see, for example, Radcliffe-Brown, I950 and Claude Lévi-Strauss, I969 [I949]) was associated with the 'ordered' continuation of social life and was ubiquitously perceived as the 'regulative ideal of human societies'. Yet, in so far as marriage is related to the exclusion and marginalization of people considered from a hetero-normative point of view as 'anomalous', marriage is linked to various forms of death, to privilege, to exclusion and to abjection. Borneman further points to how sex and desire have been excluded from most accounts of marriage, obscuring sexuality across the boundaries of marriage and stigmatizing sex- 
ual life outside of marriage (Borneman I996: 220-22I). See Gilman (I998: 22-23) for the misleading ways in which marriage and purity have been associated with one another in literature. He points out that 'love, fantasy, trust and belief in marriage' are not a prophylaxis for disease.

3. The ways HIV and AIDS have disrupted threads of intimacy and social relationships remains the theme of Chapter One. During the course of research, responses to the discovery of an HIV positive status in one or both partners in relationship often led to the dissolution of the relationship if the partners were young, to secrecy and an unwillingness to disclose in more long-term relationships, or to acrimonious accusations and the pursuit of other relationships, sometimes returning to the primary relationship.

4. In considering Eros, I draw briefly on the work of Kristeva (I987) and Levinas (I989 [1987]). See Berger (2005) for an account of the lack of attention to sexual desire in prevention work. He explores the hetero-normative exclusion of sex outside the parameters of marriage, what he calls 'dirty' sex. He insists on departing from stereotypical conceptions of a ubiquitous vulnerability of young women, for example, and in foregrounding agency in sexual encounters. See also Carole Vance (I997) in relation to the coupling of pleasure and danger in sexual relations.

5. Many people in Okhahlamba insisted that it was appropriate to use condoms with girlfriends but not with a wife.

6. Deceased relatives who had been inaugurated as ancestral shades amongst many people whom I knew in Okhahlamba were important presences in the lives of the living. They were seen to intervene in their descendents' lives, through helping them to solve problems and by inflicting ill-health when relations in the family were not harmonious. Ancestral shades also played an important role in fertility and in sex itself, making lovers desirous of one another and helping to bring together bodily fluids that would form a child in a mother's womb.

7. Ntombikayise was one of an initial group of 77 women and one man in Okhahlamba who visited the ill in their homesteads, and who provided relatives with information in relation to the clinic and hospitals. They taught relatives practical methods of providing care for family members who were extremely ill. They often played a mediatory role between medical institutions and family members, and worked as 'translators' between worlds that were not always transparent to one another.

8. Isicathamiya is a popular performance genre made up of songs of a topical nature and a particular dance style. See footnote 15 for a fuller description.

9. Abakhongi, party sent by the groom to negotiate marriage (Doke et al, I999: 402).

I0. Krige (I933: I30) refers to the way in which the colour of the initial beast was often announced by an umkhongi in marriage negotiations in the early part of the 2oth century. She names it 'eyokumemeza' (the one to call out by).

II. The delightful effects of simply calling out the name of her husband were evident in the proud way in which Ntombikayise related his full name.

I2. The phrase, 'I want you to cook for me and for my mother' is used in courting banter even by young boys.

I3. 'Robot' is the South African term for a traffic light, and Kentucky refers to the fast-food outlet, Kentucky Fried Chicken. 
I4. The term used for accepting someone as a lover is ukuqoma. Younger girls in some parts of Okhahlamba indicated their choice of a lover through a gift of beads given to a young man the girl had chosen by an older girl, iqhikiza, who mediated her courtship.

I5. Ingoma yobusuku, night song, is also known as isicathamiya, a particular genre of singing and dancing devised by Zulu migrant workers who often had to practice at night, and who restricted the volume and scope of their movements so as not to disturb others. The term isicathamiya literally means to tread softly like a cat, and perfectly captures the muted and drawnin energy of this style of performance. Feet and hand movements are delicate and contained in contrast to the overt strength and power of other forms of Zulu dance. The songs are often topical in nature. For an exploration of contemporary isicathamiya performance around HIV and AIDS, see Liz Gunner (2005, 2003). See also Veit Erlmann (I996) for an exploration of the development of the genre.

I6. Amongst families in Okhahlamba, infertility was rarely attributed to a man. If there were difficulties in having a child, it was in most cases presumed that the woman 'was to blame'.

I7. It was not unusual for children born outside of a marriage to remain with their maternal grandparents after their mother has married.

I8. It is important to note that at the time of our conversations, no antiretroviral treatment was available in Okhahlamba through the state system.

I9. See Kristeva (1987) for a discussion of the horror attached to abjection and the pollution attached to certain body fluids. See Chapter One for an account of the fear attached to the metamorphoses of the body in undergoing AIDS - a disintegration of the body from solid flesh to one leaning towards the fluid in its uncontrollable voiding of what is ingested through diarrhoea and vomiting.

20. Fiona Scorgie et al (2006), through discussion and interviews with a range of rural women in Centocow, KwaZulu-Natal, as well as at an urban site in Durban, have suggested a range of vaginal practices in which herbal and commercial substances are used to 'tighten' and 'dry' a woman's vagina, and in which other substances are used for aphrodisiacal purposes. The use of substances in the latter way is also linked to 'love magic', in which women seek to secure their relationships and the interest of their men. As such, the above practices indicate the insecurities women and girls experience in relationships with men. For further literature on vaginal practices, including 'dry sex' in South Africa, see, for example, Belkinska et al (1999); Morar and Ramjee (1997); Morar and Abdool Karim (1998); Myer et al (2005). For anthropological literature on the same topic, see Leclerc-Madlala (2002) and Scorgie (2004).

2I. For the role of both a man and a woman's shades in creating desire, in the act of sex and in conception, see Bergland (I976: 94ff) In relation to the latter points, see Robert Thornton's work (2003).

22. To understand the importance of Njabulo's response to Ntombikayise, I will briefly contrast it to others. Younger people, in returning home from Johannesburg in extremely bad health, were often deserted by their lovers. Sometimes a known girlfriend or boyfriend would not even attend the funeral of their former partner. In the case of married couples, one or both partners often chose not to disclose their status to the other, and worried that they 
had caused the illness in the other. Sometimes women silently nursed their husbands to their deaths without the virus ever being mentioned. Husbands, when seeing the decline of a wife, sometimes took up permanently with a lover or girlfriend.

23. It was common for brides to be blamed for bringing HIV and AIDS into their husband's families, just as it was common for women marrying into a patrilineage to be blamed for witchcraft within the lineage. Women, although leaving their natal homes to marry, were never fully integrated into the homes of their husbands and were regarded as strangers within a patrilineage.

24. See Henderson (2004: 50-51) for an account of the association of women with pollution in the local context. See also Ngubane (1977: 78-79). Other writers have discussed the ways in which pollution is often attributed to women, because of their ability to retain fluids associated with sex and fertility (Scorgie et al 2006. See also Leclerc-Madlala 2002). The way in which menstruation is linked with pollution is explored by Ngubane (I977: 79). In the case of Zimbabwe, see Ray et al (1996: 69).

25. Withholding a beast from the full number of bridewealth cattle, where a wife has had a child in another relationship is common practice.

26. Practices of avoidance are referred to as ukuhlonipha. See Dowling (I988) and Findlayson (I995) for in-depth exploration of linguistic forms of ukuhlonipha. See Raum (I973) for a range of avoidance practices among Zuluspeaking peoples.

27. The umgano animal should not be killed. It signified a father's generosity towards and concern for his daughter. In Okhahlamba, the animal was sometimes called 'ukhezo lomntwana', meaning 'the spoon of the child'. When grown, the heifer provided the bride and her children with milk, and was not confused with the 'goat of the spoon' (imbuzi yokhezo) (Krige, I933: 394). The latter animal was given to the bride by her husband's family to signify that she had now been sufficiently accepted in her new home and could drink the milk of her husband's cattle. The umgano beast was associated with the bride's personal shades. Bergland (I978: 207-208) refers to the same animal as 'isigodo' (tree stump on which ancestors come to rest), maintaining that there were many names for it, including umbeka, as does Krige (I933: 392). The isigodo could be one of two or three cattle, the ukwendisa cattle, that accompanied the bride to her new home as a gift from her father, and that facilitated communication with the shades of her own lineage (ibid: 206), and between the shades of her own and her husband's lineage. Whereas the other two cattle were slaughtered when the bride arrives at the groom's homestead, the isigodo, or the umgano beast, lived out its natural life in the husband's homestead, providing comfort and a direct link with the shades of the bride's former home. See Krige's description (I933: 39I) of the ukwendisa cattle taken from the bride's to the groom's home. See Braadtvedt (I927) for an extensive exploration of 'customary' marriage amongst Zulu speakers.

28. Ntombikayise was angry at the way in which herbal medicines no longer helped Njabulo.

29. In Okhahlamba, a lift in another person's car to a hospital, clinic, or healer usually cost Rioo (\$I4.28) at the time of the research. 
30. Njabulo used the phrase, 'child of a person' to refer to Ntombikayise. It is an expression in isiZulu similar in weight to the English, 'human being'.

3I. In contrast to Levinas (I988 [I987]: 40-42), Heidegger's (I996 [I953]: 239, 26Iff) notion of being encompasses death, in that 'death makes possible all other possibilities'. For Heidegger, being leans towards death, as if death may be comprehended and faced. For Heidegger, incorporating an 'understanding' of death into being constitutes supreme lucidity and virility, a rounded completion of life.

32. Sevenhuijsen (1998), Sevenhuijsen et al (2003) and Tronto (1993, I995) have written extensively on issues to do with care and gender, suggesting that nation-states need to take responsibility for aspects of care. Welfare policies that depend on voluntarism, for example, take the availability of women to provide care, and to extend the number of persons to whom they administer care, for granted. Both the invisibility of care, and hence its seeming unimportance, are tied to the fact that women and girls are largely responsible for its provision in society.

33. Men did not generally attend support groups for people living with AIDS. Although I came to know intimately and individually several men afflicted with the disease over a long period, they preferred to speak of their illness privately and chose not to join support groups. In some public meetings, male leaders raised their concern about wide-scale deaths in their neighbourhoods, but they did not, in my hearing, speak of any first-hand experience of the disease. Five out of six support groups for people living with AIDS that existed in Okhahlamba at the end of the research period were comprised solely of women, often widows, whose husbands had died of AIDS-related illnesses. With encouragement, and with the increasing availability of antiretroviral treatment, younger women and girls joined support groups. The sixth support group comprised mostly men and was created through the husband of a home-based carer. The home-based carer 'recruited' members for the group through selling beer at her homestead.

34. Wedding protocol in Okhahlamba required that when an umkongi first arrived at a prospective bride's home, he would stand outside the homestead, and when he called out that he wanted to set up negotiations for marriage, he was at first sent away and told to return the next day. At wedding ceremonies, the bride's and the groom's parties tried to outdo one another in their singing and dancing. Physical fights often broke out during marriage celebrations. In relation to the rivalry of respective wedding parties, see Braadvedt (I927: 557), Krige (I936: I38-I40) and Samuelson (I928: II5).

35. Izingcosho, are described by Doke et al (I990: I25) as 'pickings'. The word is derived from the verb cosha, to pick up with the fingers.

36. See Bergland (I976: IIoff, I99ff, 215, 228ff); Bryant (I949: 274-75); Holleman (I940: 3I-75); Hunter (I979: 52, I90-93, 234); Krige (I933: I2O-I23, I84I88); Ngubane (I977: 47-48, 6I-67) and Poland, Hammond-Tooke \&Voigt (2003). See also Ferguson (1985) for important insights into how the significance of cattle amongst Basotho was not an archaic residue, but was fully integrated into a 'modern' political economy.

37. See Vilikazi (1965: 64) for reference to gifts exchanged in marriage. He refers to the gifts as izicelo and imibondo.

38. Umembeso refers to a set of gifts and clothing given by the groom to his wife's family during the build-up to a marriage. Umabo refers to a set of gifts 
given by the bride to the groom's people. Krige (I933: I37-I38) suggests that the gifts given by the bride to the groom's people at her wedding were important. But she does not explain why this may be so. She lists presents given by the bride as 'mats, baskets, beads etc.' (ibid.), 'blankets ... beer strainers, brooms etc.' (ibid: I52) and 'household utensils' (ibid: I22).

39. Ntombikayise's mother related several stories to me in which the dead insisted on receiving the blanket, pillow and sleeping mat due to them in wedding exchanges. Their insistence had been communicated through repeated dreams, often on the part of the relative who had failed to set the gifts aside for them. The dreams would cease as soon as the person had fulfilled their obligations. Ntombikayise's mother stated that it was more important to give gifts to the dead than to the living, because it was easier to explain the financial difficulties of a family to the living (interview, I6 June 2004). See Vilikazi (I965: 69) for reference to gifts given to ancestral shades during marriage negotiations.

40. See Ngubane (I977: 66).

4I. See Dieter Reutsch (I998: 20), who in an examination of the social life of pots amongst the Mabaso of Msinga in KwaZulu-Natal, reiterates similar points to do with the association between women, earth, fertility and the ancestral shades. Reutsch (I998: 37) distinguished between pots in which beer was brewed, which often retained their earth colouring, and izinkamba, the drinking vessels that were also used to make offerings to the shades at the umsamo. The latter vessels were always blackened through reduction firing with cow dung. Their blackened colour was a way of paying respect to the ancestors (see Davidson, 1985: 74-7). Pots in which beer was brewed were also smeared with fresh cow-dung. The inclusion of cow-dung in processes of pottery making and usage 'strengthen[ed] the association between the ancestors and the vessels, as cattle and their by-products [were] mediums through which the living descendents ... communicate[d] with their ancestors' (Reutsch I998: 37).

42. At rituals and ordinary occasions, drinking vessels were passed between drinkers, often marking their relative age and status through the order in which the vessel was passed from one person to another. For an in-depth exploration of the ways in which beer drinking consolidates social relationships between neighbours and relatives among Xhosa speakers in the Transkei, see Patrick McAllister (200I; I997: 294ff, 303). He writes: 'Important abstract social principles, such as locality, neighbourliness, co-operation, sharing and the interdependence of homesteads, are given concrete expression and perpetuated [in the beer drink]' (I997: 303). Beer is also shared between former antagonists in ceremonies of reconciliation. See Krige (I933: 59), for example, and Bergland (I976: 323-25).

43. The fire used to burn the offered meat was preferably made with two sticks: a 'male' and a 'female' stick (Reutsch, I998: 29). As heat was associated with reproduction, the heat produced with the sticks corresponded to sexual intercourse. Heat beneath a pot was always a metaphor for heterosexual sex, as the fire was associated with a man's penis and the pot with the womb of a woman in which a child was moulded by the shades of both parents.

44. During the course of open-ended interviews, many people in Okhahlamba mentioned the value of making things with their hands, as well as the idea that a person lived through the work of his or her hands. Hand-crafted ob- 
jects were particularly associated with the 'ways of isiZulu' as opposed to 'the ways of the whites' (isiLungu).

45. In Moari law, for example, the legal tie that develops through the exchange of things is 'one between souls, because the thing itself possesses a soul', and 'is of the soul' (Mauss I990: I2). Bayly ([I986] 2003), writing on cloth in India, makes a similar point. She describes how cloth absorbs the substance of the people who make it and who wear it, substances that are both benign and polluting.

46. See, for example, Plato's The Symposium ([1951] I985: 59-66), where Aristophanes discusses the three sexes (male, female and hermaphroditic) in relation to his amusing theory of circular beings, the original human beings who were made up of two parts (two male parts, two female parts or one male and one female part). From the time Zeus split each circular being into two, the two halves have been seeking one another desirously ever since.

47. For an exploration of the open-ended, non-goal directed nature of the caress, see Luce Irigaray's (I986) tribute to Emmanuel Levinas in her piece, 'The fecundity of the caress'.

\section{On Accompanying the Ill}

I. Few detailed studies on home-based care have been conducted within the KwaZulu-Natal region. The exceptions are two unpublished Master's theses: Ngubo (1996) and Nkwe-Mabua (2000). Ngubo describes an early homebased care programme in the Valley of a Thousand Hills, and Nkwe-Mabua outlines home-based care from a planning and practice perspective within KwaZulu-Natal. Uys (2002) has written on activities of paid home-based carers in a hospice setting in the Pietermaritzburg region. In earlier work, Russel and Schneider (2000) helped to document the home-based care programmes in place throughout the country and how they could be extended. Nina Hunter (2005) sought to document home-based care in 36 households across six research sites in KwaZulu-Natal, from the perspective of the carers. From a national perspective, critical work in relation to describing the extent of home-based care services within the country has been done by Russel and Schneider (2000). See Goudge, Gibson and Msigango (2003) for an account of the role of community based organizations (CBOs) in the rollout of home-based care and an appraisal of government responsibility in relation to this reality.

2. Antiretroviral treatment only became available through the sub-district hospital in March 2005. It naturally took some months for the hospital to build up the numbers of people on antiretroviral medication.

3. Through Broad Reach, an organization funded by the United States President's Emergency Plan for AIDS Relief (PEPFAR), Ioo patients from one ward in Okhahlamba and areas close to the town of Winterton and the mountain resorts were placed on antiretroviral treatment before they were available through the public health system. Broad Reach set up a number of projects in South Africa relying on private doctors to issue the medicine and to monitor patients. Members of local NGOs were called upon to coordinate the projects in Okhahlamba. Home-based carers from within the ward were 
asked to identify potential patients and to provide training to do with antiretroviral therapies and a life-long commitment to the medication. Broad Reach provided the cost of the medication through the importation of drugs from American pharmaceutical companies. It was envisaged that the patients on the Broad Reach programme would be absorbed by the public health system when Broad Reach withdrew its funding. Emmaus Hospital in Okhahlamba was soon in a position to quickly absorb the Broad Reach patients if necessary.

4. That people who are HIV positive require adequate nutrition was widely promulgated by NGOs, by the Department of Health and in the media in general. Communal and individual vegetable gardens had therefore been encouraged in Okhahlamba, predominantly through NGO structures. It was necessary to build strong enclosures for the gardens in the area where Zinhle lived because roaming goats, pigs and cattle could easily destroy anything planted. The women did not have money to buy fencing, and so had to carry heavy loads of wood to construct their gardens.

5. In the conversation, the women mainly referred to one another using their fathers' family names. Although in Okhahlamba, married women were referred to by their husband's surnames in their official dealings with state institutions, in everyday cultural practice, women retained the family names of their fathers. Their doing so is an indication of how women marrying into their husband's patrilineal families were not regarded as members of a husband's family, but upheld an identity linked to their own agnates.

6. In Okhahlamba and in most poor, rural and urban contexts within South Africa, as well as in southern Africa as a whole, women and girls overwhelmingly provide care for the ill (see Akintola 2004a, 2004b, Marais, 2005: 67, Mills 2004, Urdang 2006: I65). They are also disproportionately infected with HIV and AIDS. In some respects, poor women and children encapsulate what it means to live within the margins of the state (see Das \& Poole 2004), yet they contribute fundamentally to its reproduction.

7. During the time of mourning for a husband, widows were generally prohibited from working for a wage.

8. Accounting for all ro7 deaths in the area, the deceased included: I grandfather's sister, I father's brother, 3 grandfathers, 3 grandmothers, 20 fathers, I2 mothers, 37 children of the home, 22 brides of the home, 2 grandchildren and 6 unknown.

9. As part of a job-shadow programme, HIVAN provided funding for a group of home-based carers from Okhahlamba to visit the Church of Scotland Hospital in Msinga for a week in September 2004. A number of homebased carers from Msinga were later to visit Okhahlamba. The hospital in Msinga was able to access antiretroviral therapies several years before the national roll-out because it constituted an important research site for researchers from Yale University.

Io. The counsellor concerned worked for the Bergville municipality and contributed funds for the cheapest pine coffin on the market. At one point during my stay, Zinhle informed me that the fund for coffins had run out and that neighbours subsequently pooled funding to bury the dead.

II. After a person had died, neighbours visited the bereaved at their homestead throughout the day and into the night for several days, a time referred to as isililo. An account of an isililo is given in Chapter One. 
I2. Matt. 25: 34-40: 'Then shall the King say unto them on his right hand, ye blessed of my Father, inherit the kingdom prepared for you from the foundation of the world: for I was ahungered, and ye gave me meat: I was thirsty, and ye gave me drink: I was a stranger, and ye took me in: naked, and ye clothed me; I was sick, and ye visited me: I was in prison, and ye came to me. Then shall the righteous answer him saying, Lord, when saw we thee ahungered, and fed thee? or thirsty, and gave thee drink? When saw we thee a stranger, and took thee in? or naked, and clothed thee? or when saw we thee sick, or in prison, and came unto thee? And the King shall answer and say unto them, Verily I say unto you, Inasmuch as ye have done it unto one of the least of my brethren, ye have done it unto me.'

I3. One volunteer, for example, likened her hunger as a child and the physical and mental cruelties inflicted on her by her malumekazi (uncle's wife) as not being dissimilar to being ill. She was particularly concerned that her patients should be protected from harsh forms of speech and that they be "satisfied' by their verbal exchanges with her (interview, 26 March 2003).

I4. The body of home-based carers included izangoma (diviners) as well as staunch Christians. It was a governing principle of the group that it was for 'everyone in Okhahlamba', regardless of their political affiliations or personal beliefs.

I5. During the research period, a group of white farmers and their wives in Okhahlamba donated 30 tons of maize to impoverished communities in the region. The group was motivated to do so through strong religious convictions. They relied on home-based carers to identify the poorest homesteads in their neighbourhoods so that maize and basic household goods could be delivered to them. The farmers also assisted families and orphans in obtaining social grants due to them through the welfare system. Home-based carers were perceived as being less biased in their identification of poor families than, for example, counsellors, who when they were involved in food distribution, chose people affiliated to their own political parties, as well as within their families.

I6. The particular doctor proved to be seminal in ensuring the development of hospital protocols for the reception of antiretroviral therapies and their rollout in a surprisingly short period of three months. The hospital received accreditation from the Department of Health for the roll-out in November 2004. Due to a shortage of Stocrin in the country, however, patients began receiving antiretroviral therapies through the public health system in March 2005. Drawing on the example of another district, the doctor devised a plan by which antiretroviral medication could be issued from the clinics rather than from the hospital. The latter plan became fully operational in 2006 , and was made possible through doctors visiting the clinics for a few days a week, and through nursing sisters at the clinics performing many of the preparatory tests and much of the training necessary for the issuing of the drugs. This system has ensured that a larger number of people are accommodated in the antiretroviral programme than would have been possible if the roll-out had been centralized within the hospital. In addition, patients do not have to travel such long distances to have regular meetings with a doctor and to receive their medication. In September 2007, I500 people were on antiretroviral therapies within the public health system in Okhahlamba. By the end of 2007, the hospital and its clinics had already achieved the targets 
set by the Department of Health for 2012 in the National Strategic Plan for HIV and AIDS, Sexually Transmitted Infections (STIs) and Tuberculosis (DOH 2007). The doctor in question was later approached by neighbouring districts to convey to them how he had planned ARV roll-out from the clinics. He attributed the success of his approach in Okhahlamba to the fact that there had long been close working relationships in the region between the hospital and the clinics. If this had not been the case, the approach would have been more difficult to implement.

I7. No official action was taken against the person in question, however.

I8. The drawn-out nature of formal complaint procedures within the Provincial Department of Health was attested to in conversations between myself and doctors at Emmaus Hospital.

I9. Bactrim, an antibacterial antibiotic, a combination of trimethoprim and sulfamethoxazole, is prescribed in the treatment of a number of bacterial infections. In relation to people with weakened immune systems it is used for the prevention of Pneumocystis carinii pneumonia.

20. After home-based carers visited Msinga, a group from Msinga in turn visited Okhahlamba.

2I. Busisiwe's confusion lay in the fact that she had tried every avenue in seeking health care without satisfaction. Her experience had made her distrustful of the formal health system.

22. December was a particularly busy time in Okhahlamba because migrant workers returned home for the Christmas period.

23. Community health workers were distinguished from community-based caregivers. In order to qualify as a community health worker, a minimum standard of education was required. Within KwaZulu-Natal, it was generally only community health workers who received a stipend from the state for delivering health messages to communities. Ironically it is claimed that it is difficult to measure the work of a home-based carer. As we have seen in Zinhle's story, educational level is not an indication of the standard of care that a woman may offer her patients. Introducing such measures into homebased care evaluations would immediately cut out most of the carers in Okhahlamba, many of whom provided services of a standard far above any call to duty.

24. See Hein Marais (2005: 70), who is also concerned with the importance of paying stipends to home-based caregivers. See Stephanie Urdang (2006: I76), who shows how women and girls are withdrawn from formal employment and from schooling in order to take care of the ill. Care-givers within homes are thus confined within a domestic setting, where from the point of view of public life, their efforts sink into invisibility (Marais 2005: 67).

25. See Giese et al (2003), Hunter (2005) and Ogden et al (2004), who write of the stress experienced by home-based carers in doing their work.

26. Services such as crèches, laundries, pre-packaged food, restaurants, and oldage care facilities enable women to participate more broadly in the formal economy. Despite these facilities, women still take on a greater proportion of care work within homes. 


\section{Appendix: Interlocutors and Research Methods}

I. They were interviewed by Mam' Shabalala, together with several staff members of the NGO mentioned above, as well as Department of Health area personnel responsible for community health worker training in the clinics. 



\section{Bibliography}

Abdool Karim, Q., S.S. Abdool Karim, B. Singh, R. Short \& S. Ngxongo. I992a. Seroprevalence of HIV Infection in Rural South Africa. AIDS, 6: 1535-539.

Abdool Karim, Q., S.S. Abdool Karim, E. Preston-Whyte \& N. Sanker. I992b. Reasons for Lack of Condom Use among High School Students. South African Medical Journal, 82: I07-IIo.

Abdool Karim, S.S. \& Q. Abdool Karim. 2005. HIV/AIDS in Southern Africa. New York: Cambridge University Press.

Abdool Karim, Q., E. Preston-Whyte \& S.S. Abdool Karim. I992. Teenagers Seeking Condoms at Family Planning Clinics: Part I - A User's Perspective \& Part 2 - A Provider's Perspective. South African Medical Journal, 82: 356-59, 36062.

AIDS Committee of Actuarial Society of Southern Africa (ASSA). 2000. Actuarial Projection of the Epidemic: Summary Statistics. http://www.actuarialsociety.co.za/aids/

Adorno, T.W. 2003. Can One Live After Auschwitz? R. Tiedemann (ed.). Stanford: Stanford University Press.

Akintola, O. 2004a. Home-Based Care: A Gendered Analysis of Informal Care Giving for People Living with HIV and AIDS in a Semi-Rural South African Setting. PhD thesis, University of KwaZulu-Natal.

Akintola, O. 2004b. A Gendered Analysis of the Burden of Care on Family and Volunteer Caregivers in Uganda and South Africa. Health Economics and HIV/ AIDS Research Division (HEARD), University of KwaZulu-Natal.

Amit-Talai, V. \& H. Wulff (eds.). I995. Youth Cultures: A Cross-Cultural Perspective. London: Routledge.

Appadurai, A. (ed.). I986. The Social Life of Things: Commodities in Cultural Perspective. Cambridge: Cambridge University Press.

Aristotle. I979. On the Generation of Animals, Loeb 366. A. Peck (trans.). Harvard: Harvard University Press.

Ashforth, A. 2004. Witchcraft, Violence and Democracy in South Africa. Chicago: University of Chicago Press.

Ashforth, A. 2002. An Epidemic of Witchcraft? The Implications of AIDS for the Post-Apartheid State. African Studies, 6I (I): I2I-I43.

Ashforth, A. 2000. Madumo: A Man Bewitched. Chicago: University of Chicago Press.

Aspaas, H. 1999. AIDS Orphans in Uganda: Geographical and Gender Interpretations of Household Resources. Social Science Journal, 36 (2): 20I-226.

Atwell, D. 2005. Rewriting Modernity: Studies in Black South African Literary History. Durban, Pietermaritzburg: University of KwaZulu-Natal Press.

Austin, J.L. I962. How to Do Things with Words. Cambridge, Mass.: Harvard University Press.

Barnett, T. \& P. Blaikie. 1992. AIDS in Africa: Its Present and Future Impact. London: Belhaven Press. 
Barnett, T. \& A. Whiteside. 2002. AIDS in the Twenty-First Century: Disease and Globalization. Basingstoke, New York: Palgrave-Macmillan.

Basaza, R. \& K. Kaija. 2002. The Impact of HIV/AIDS on Children: Lights and Shadows in the 'Successful Case' of Uganda, pp. I-73. In AIDS, Public Policy and Child Well-being, G. Cornia (ed.). Florence: UNICEF-IRC.

Bataille, G. I988. The Story of the Eye: With essays by Susan Sontag and Roland Barthes. Harmondsworth: Penguin Books.

Bataille, G. I99I. The Accursed Share (vol. 1). R. Hurley (trans.). New York: Zone Books.

Bataille, G. I997. Madame Edwarda, pp. 223-36. In F. Botting \& S. Wilson (eds.), The Bataille Reader. Oxford: Blackwell Publishers.

Battaglia, D. (ed.). I995. On Practical Nostalgia: Self-Prospecting among Urban Trobrianders, pp. 77-96. In The Rhetorics of Self-Making. Berkeley: University of California Press.

Bayly, C.A. 2003 (1986). The Origins of Swadeshi (Home Industry): Cloth and Indian Society, I700-1930, pp. 285-322. In A. Appadurai (ed.), The Social Life of Things: Commodities in Cultural Perspective. Cambridge: Cambridge University Press.

Beck, R.B. 2000. The History of South Africa. Westport: Greenwood Press.

Belkinska, M.E., H.V. Rees, I. Kleinschmidt, \& J. McIntyre. I999. The Practice and Prevalence of Dry Sex among Men and Women in South Africa: A Risk Factor for Sexually Transmitted Infections? Sexually Transmitted Infections, 75: I78-I80.

Berger, J. 2005. Re-sexualizing the Epidemic: Desire, Risk and HIV Prevention. Development Update, 5 (3): 45-67.

Bergland, A.-I. 1976. Zulu Thought-Patterns and Symbolism. London: Hurst \& Company; Johannesburg: David Philip.

Bergland, A.-I. I957. Some African Funerary Inversions. Unpublished Doctoral Thesis, Uppsala.

Benjamin, W. I973. Illuminations. H. Zohn (trans.). London: Collins/Fontana.

Bettelheim, B. I978. The Uses of Enchantment: The Meaning and Importance of Fairy Tales. London: Penguin Books.

Bhabha, H. I994. The Location of Culture. London: Routledge.

Bhabha, H. \& J. Comaroff. 2002. Speaking of Postcoloniality in the Continuous Present: A Conversation, pp. I4-46. In Relocating Postcolonialism, D.T. Goldberg \& A. Quayson (eds.). Oxford: Blackwell.

The Bible: King James Version. 2002. Uhrichsville, Ohio: Barbour Press.

Biehl, J. 2005. Vita: Life in a Zone of Social Abandonment. Berkeley: University of California Press.

Bleek, W.H.I. I952. Zulu Legends. Pretoria: Van Schaik.

Bloch, E. (I935) I976. Nonsynchronism and the Obligation to its Dialectics. New German Critique, II: 22-38.

Bloch, M. \& D. Sperber. 2006. Kinship and Evolved Psychological Dispositions: The Mother's Brother Controversy Reconsidered, pp. II5-I4O. In D.R. Olson $\&$ M. Cole (eds.), Technology, Literacy and Evolving Society: Implications of the Work of Jack Goody. London: Routledge.

Borneman, J. I996. Until Death Do Us Part: Marriage/Death in Anthropological Discourse. American Ethnologist, 23 (2): 215-235.

Botting, F. \& S. Wilson (eds.). I997. The Bataille Reader. Oxford: Blackwell Publishers. 
Bourdieu, P. I977. Outline of a Theory of Practice. Cambridge: Cambridge University Press.

Braadvedt, H.P. I927. Zulu Marriage Customs and Ceremonies. South African Journal of Science, 24: 553-565.

Bray, R. 2003. Predicting the Social Consequences of Orphanhood in South Africa. Centre for Social Science Research Working Paper No.29. Cape Town: Centre for Social Science Research, University of Cape Town.

Broad Reach Healthcare Programme. 2005. Scaling up ARV Therapy: Lessons learned and New Models. Presented by Ernest Darkoh. www.broadreachhealthcare.com

Brookes, E.H. 1987. A History of Natal. Pietermaritzburg: University of Natal Press.

Bryant, A.T. I929. Olden Times in Zululand and Natal: Containing Earlier Political History of the Eastern-Nguni Clans. London. New York, Toronto: Longmans, Green and Co.

Bryant, A.T. 1905. A Zulu-English Dictionary. Marianhill: Marianhill Monastry.

Buber, M. I996. Thou and I. Charles Schribner's Sons (trans). New York: Touchstone.

Bundy, C. I979. The Rise and Fall of the South African Peasantry. London: James Currey.

Butler, J. I997. Excitable Speech: A Politics of the Performative. New York, London: Routledge.

Cairns, E. I996. Children and Political Violence: Understanding Children's Worlds. London: Blackwell Publishers.

Callaway, H. I870. The Religious System of the Amazulu. London: Folk-Lore Society.

Cameron, E. 2006. Normalising Testing - Normalising AIDS. 4th May 2006. Forum Lecture, University of KwaZulu-Natal.

Cameron, E. 2005. Witness to AIDS. Cape Town: Tafelberg.

Campbell, C. I997. Migrancy, Masculine Identities and AIDS: The Psychosocial Context of HIV Transmission on the South African Gold Mines. Social Science and Medicine, 45 (2): 273-28I.

Canguilhem, G. 20II. Writings on Medicine (Écrits sur La Médecine, Seuil 2000). T. Myers \& S. Geroulanos (trans.). Forms of Living series. New York: Fordham University Press.

Caputo, J. I993. Against Ethics. Bloomington: Indiana University Press.

Carsten, J. (ed.). 2000. Cultures of Relatedness: New Approaches to the Study of Kinship. Cambridge: Cambridge University Press.

Carsten, J. (ed.). I995. The substance of Kinship and the Heart of the Hearth: Feeding, Personhood, and Relatedness among Malays in Pulau Langkawi. American Ethnologist, 22 (2): 223-24I.

Carter, M.R. \& J. May. I999. Poverty, Livelihood and Class in Rural South Africa. World Development, 27 (I): I-20.

Children's Institute. II October 2005. Virginity Testing and the Children's Bill: Discussion Paper. University of Cape Town: Children's Institute.

Chimwaza, A.F. \& S.C. Watkins. 2004. Giving Care to People with Symptoms of AIDS in Rural Sub-Saharan Africa. AIDS Care, I6 (7): 795-807.

Christopher, A.J. I969. A Study in Colonial Land Settlement. PhD dissertation, University of Natal. 
Clifford, J. I988. The Predicament of Culture: Twentieth-Century Ethnography, Literature, and Art. Cambridge, Mass: Harvard University Press.

Clifford, J. \& G. Marcus. I986. Writing Culture: The Poetics and Politics of Ethnography. Berkeley: University of California Press.

Cohen, R.A. (ed.). I986. Face to Face with Levinas. Albany: State University of New York.

Colenso, J.W. I855. Zulu-English Dictionary. Pietermaritzburg.

Coles, R. 1986. The Political Lives of Children. Boston: Houghton Mifflin.

Comaroff, J. \& J. Comaroff. 2004. The Struggle between the Constitution and 'Things African'. The WISER Review: 6.

Comaroff, J. \& J. Comoroff. I999. Occult Economies and the Violence of Abstraction: Notes from the South African Postcolony. American Ethnologist, 26 (2): 279-303.

Connolly, M. \& J. Ennew. I996. Introduction: Children Out of Place. Childhood, 3 (2): I3I-I45.

Connolly, W.E. I999. Why I am not a Secularist. Minneapolis, London: University of Minnesota Press.

Coombe, C. 2000. Keeping the Education System Healthy: Managing the Impact of HIV and AIDS on Education in South Africa. Current Issues in Education, ejournal of Teacher College Columbia.

Csordas, T.J. 2002. Body/Meaning/Healing. Basingstoke, New York: PalgraveMacmillan.

Csordas, T.J. (ed.). (I994) 2000. Embodiment and Experience: The Existential Ground of Culture and Self. Cambridge: Cambridge University Press.

Csordas, T.J. I999. The Body's Career in Anthropology, pp. I72-205. In H. Moore (ed.), Anthropological Theory Today. Cambridge: Polity Press.

Dalley, G. I996. Ideologies of Caring: Rethinking Community and Collectivism. Houndmills, London: Macmillan.

Daniel, M. 2003. Children Without Parents in Botswana: The Safety Net and Beyond. Paper presented at a Scientific Meeting on Empirical Evidence for the Demographic and Socio-Economic Impact of AIDS, 26-28th March, Health Economic and HIV/AIDS Research Division (HEARD), University of Natal Durban, South Africa.

Das, V. 2000. The Act of Witnessing: Violence, Poisonous Knowledge, and Subjectivity, pp. 205-225. In V. Das, A. Kleinman, M. Ramphele, \& P. Reynolds (eds.), Violence and Subjectivity. Berkeley: University of California Press.

Das, V. I997. Language and Body: Transactions in the Construction of Pain, pp. 67-9I. In A. Kleinman, V. Das, \& M. Lock (eds.), Social Suffering. Berkeley: University of California Press.

Das, V. 1996. Language and Body in the Construction of Pain. Daedalus, I25 (I): $67-93$.

Das, V. (ed.). I990. Our Work is to Cry: Your Work is to Listen, pp. 346-398. In Communities, Riots and Survivors in South Asia. Oxford: Oxford University Press.

Das, V. \& D. Poole. 2004. Anthropology in the Margins of the State. New Delhi: Oxford University Press.

Das, V. \& P. Reynolds. 2003. The Child on the Wing: Children Negotiating the Everyday in the Geography of Violence. An opening paper for Workshop One of a project under the Rockefeller Foundation Resident Fellowships in the 
Humanities and the Study of Culture Program at Johns Hopkins University 2003-2006. I5 November 2003.

Das, V., A. Kleinman, M. Lock, M. Ramphele, \& P. Reynolds (eds.). 200I. Remaking the World: Violence, Social Suffering, and Recovery. Berkeley: University of California Press.

Das, V., A. Kleinman, M. Ramphele, \& P. Reynolds (eds.) 2000. Violence and Subjectivity. Berkeley: University of California Press.

Davidson, P. I985. South African Beer Pots. African Arts, I8 (3): 74-77.

Davis, C.O. 2000. Death in Abeyance: Illness Therapy among the Tabwa of Central Africa. Edinburgh: Edinburgh University Press.

De Boeck, F. I998. Beyond the Grave: History, Memory and Death in Postcolonial Congo/Zaire, pp. 2I-57. In R. Werbner (ed.), Memory and the Post Colony: African Anthropology and the Critique of Power. London: Zed Books.

De Boeck, F. \& A. Honwana (eds.). 2004. Makers and Breakers, Made and Broken. Children and Youngsters as Emerging Categories in Postcolonial Africa. London: James Currey.

De Boeck, F. \& M.-F. Plissart. 2004. Kinshasa: Tales of the Invisible City. GhentAmsterdam: Ludion.

Delius, P. \& C. Glaser. 2002. Sexual Socialisation in South Africa: A Historical Perspective. African Studies, 6I (I): 27-54.

Devisch, R. 200I. Sorcery, Forces of Life and Death among the Yaka of Congo, pp. IOI-I30. In G.C. Bond \& D.M. Ciekawy (eds.), Witchcraft Dialogues: Anthropological and Philosophical Exchanges. Athens, Ohio: Ohio University Center for International Studies.

Dent, G.R. \& C.L.S. Nyembezi. I969. Scholar's Zulu Dictionary. Pietermaritzburg: Shuter and Shooter.

Desjarlais, R. I997. Shelter Blues: Sanity, Selfhood and the Homeless. Philadelphia: University of Pennsylvania Press.

Desjarlais, R. 1994. Struggling Along: The Possibilities for Experience Among the Homeless Mentally Ill. American Anthropologist, 96 (4): 886-9oI.

Derrida, J. 200I. The Work of Mourning. P.-A. Brault \& M. Naas (eds.). Chicago, London: University of Chicago Press.

Derrida, J.I989. Memoires for Paul de Man. C. Lindsay, J. Culler, E. Cadava \& P. Kamuf (trans.). New York: Columbia University Press.

De Sade, M. I987. The 120 Days of Sodom and Other Writings. R. Seaver \& A. Wainhouse (trans. \& eds.). New York: Grove Press.

De Sade, M. I988. Juliette. A. Wainhouse (trans.). New York: Grove Press.

De Sade, M. I990. Justine, Philosophy in the Bedroom and Other Writings. A. Wainhouse (trans.). New York: Grove Press.

Doke, C.M \& B.W. Vilikazi. I948. Zulu-English Dictionary. Johannesburg: Witwatersrand University Press.

Doke, C.M., D.M Malcolm, J.M.A. Sikakana \& B.W. Vilakazi. I990 (2006). English-Zulu, Zulu-English Dictionary. Johannesburg: University of the Witwatersrand Press.

Dorrington, R. 200I. The Demographic Impact of HIV/AIDS in South Africa by Province, Race and Class. Paper presented to the AIDS in Context Conference, 4-7 April, University of the Witwatersrand, Johannesburg.

Dorrington, R., D. Bourne, D. Bradshaw, R. Laubscher \& I. Timaeus. 200I. The Impact of HIV AIDS on Adult Mortality in South Africa, Technical Report, Burden of Disease Research Unit. Cape Town: Medical Research Council. 
Dorrington, R., D. Bradshaw \& D. Budlender. 2002. HIV/AIDS Profile of the Provinces of South Africa: Indicators for 2002. Pretoria: Research Council and Actuarial Society of South Africa.

Dorrington R, T.A. Moultrie \& I.M. Timaeus. 2004. Estimation of Mortality using the South African Census 200I Data. Centre for Actuarial Research Monograph No. II, Cape Town: University of Cape Town.

Douglas, M. (I960) I980. Purity and Danger. An Analysis of the Conceptions of Pollution and Taboo. London: Routledge \& Kegan Paul.

Douglas, M. (1970) I982. Natural Symbols: Explorations in Cosmology. New York: Pantheon.

Dowling, T. 2004. uQedisizwe - The Finisher of the Nation: Naming and Talking about HIV/Aids in African languages. Unpublished article circulated on the Internet.

Dowling, T. I988. Isihlonipho Sabafazi -The Xhosa Women's Language of Respect. M.A. Thesis. University of Cape Town.

Drew, R., G. Foster \& J. Chitima. I996. Cultural Practices of Orphaned Families in the North Nyanga District of Zimbabwe. Journal of Social Development in Africa, II: 79-86.

Du Preez, M. 2004. Of Warriors, Lovers and Prophets: Unusual Stories from South Africa's Past. Cape Town: Zebra Press.

Durkheim, E. I951. Suicide: A Study in Sociology. Glencoe: The Free Press.

Durkheim, E. I947. The Division of Labour in Society. Glencoe Illinois: Free Press.

Ennew, J. I994. Parentless Friends: A Cross-Cultural Examination of Networks Amongst Street Children and Youth, pp. 409-426. In F. Nestmann \& K. Hurrelmann (eds.), Social Networks and Social Support in Childhood and Adolescence. Berlin, New York: Walter de Gruyter.

Ennew, J. 200I. Dead Parents or Absent Parents: Who is Defining Orphans in the Twenty-First Century? Some Reflections on Policies for Orphans in SubSaharan Africa and South East Asia. Notes towards a presentation at the Conference on 'Orphans and Vulnerable Children in Africa' University of Uppsala, I3-I6 September 200I.

Erlmann, V. I996. Nightsong: Performance, Power and Practice in South Africa. Chicago: Chicago University Press.

Etherington, N. I989. The 'Shepstone System' in the Colony of Natal and Beyond its Borders, pp. I70-I92. In A. Duminy \& B. Guest (eds.), Natal and Zululand from the Earliest Times to 1910: A New History. Pietermaritzburg: University of Natal Press.

Eves, R. 2003. AIDS and Apocalypticism: Interpretations of the Epidemic from Papua New Guinea. Culture, Health Q Sexuality: An International Journal for Research, Intervention and Care, 5 (3): 249-264.

Fabian, J. 1973. How Others Die: Reflections on the Anthropology of Death, pp. I77-20I. In A. Mack (ed.), Death in American Experience. New York: Schoken Books.

Fabian, J. I983. Time and the Other: How Anthropology Makes Its Object. New York: Columbia University Press.

Farmer, P. 2003. Pathologies of Power. Berkeley: University of California Press. 
Farmer, P. I997. On Suffering and Structural Violence: A View from Below, pp 26I-283. In A. Kleinman, V. Das and M. Lock (eds.), Social Suffering. Berkeley: University of California Press.

Farmer, P. I992. AIDS and Accusation: Haiti and the Geography of Blame. Berkeley: University of California Press.

Fassin, D. 2007. When Bodies Remember. Experiences and Politics of AIDS in South Africa. Berkeley: University of California Press.

Ferguson, J. I985. The Bovine Mystique: Power, Property and Livestock in Rural Lesotho. Man, (20): 647-74.

Ferguson, J. 1988. Cultural Exchange: New Developments in the Anthropology of Commodities. Cultural Anthropology, 3 (4): 488-573.

Ferme, M.C. 200I. The Underneath of Things: Violence, and the Everyday in Sierra Leone. Berkeley: University of California Press.

Findlayson, R. I995. Women's Language of Respect: Isihlonipho sabafazi, pp. I40-53. In R. Mesthrie (ed.), Language and Social History. Cape Town: David Philip.

Fortes, M. I969. Kinship and the Social Order. London: Routledge.

Foucault, M. I986. The Care of the Self: History of Sexuality, Vol. 3. R. Hurley (trans.). New York: Pantheon.

Foucault, M. (I978) I981. History of Sexuality: Volume One, an Introduction. R. Hurley (trans.). Harmondsworth: Penguin Books.

Foucault, M. I977. Discipline and Punish: The Birth of the Prison. A. Sheridan (trans.). London: Allen Lane.

Franklin, S. \& S. McKinnon. 200I. Relative Values: Reconfiguring Kinship Studies. Durham: Duke University Press.

Gardiner, A.F. I836. Narrative of a Journey to the Zoolu Country in South Africa. London: William Crofts.

Geertz, C. I974. Myth, Symbol, and Culture. New York: W.W. Norton.

Geschiere, P. I997. The Modernity of Witchcraft: Politics and the Occult in Postcolonial Africa. P. Geschiere \& J. Roitman (trans.). Charlottesville: University of Virginia.

Giese, S., H. Meintjes, R. Croke \& R. Chamberlain. 2003. Health and Social Services to Address the Needs of Orphans and Other Vulnerable Children in the Context of HIV/AIDS: Research Report and Recommendations. Report submitted to HIV/AIDS Directorate, National Departments of Health, January 2003. Cape Town: Children's Institute, University of Cape Town.

Gilman, S.L. I998. Love + Marriage $=$ Death: STDs and AIDS in the Modern World, pp. I4-39 in Love + Marriage = Death and Other Essays on Representing Difference. Stanford: Stanford University Press.

Goldman, L.R. 1998. Child's Play: Myth Mimesis and Make Believe. Oxford: Berg.

Goldstein, K. I933. L’Analyse de l'aphasie et l'essence du langage. Journal de PsYchologie Normale et Pathologique, 30: 430-96.

Goody, J. I959. The Mother's Brother and Sister's Son in West Africa. Journal of the Royal Anthropological Institute, 89: 6I-88.

Goudge, J, L. Gibson \& L Msigango. 2003. How to 'Roll-Out' CBO Provided HomeBased Care for AIDS: Government's Role? Centre for Health Policy, Johannesburg.

Grosz, E. I994. Volatile Bodies: Towards a Corporeal Feminism. Bloomington, Indianapolis: Indiana University Press. 
Gunner, E. 2003. 'Those Dying Generations at their Song': Singing of Life, Death and AIDS in Contemporary KwaZulu-Natal. English in Africa, 46 (2): 4I-53.

Gunner, E. 2005. Mapping Texts Differently: A Case for Re-reading the South African Imaginary. Gramma: Journal of Theory and Criticism. Sp. Iss. on Comparative Literature and Global Studies, I3: I3I-I46 (School of English, Aristotle University of Thessaloniki, Greece).

Guest, W.R. I962. The Langalibalele Rebellion and its Consequences I873-I874. B.A. Honours thesis. University of Natal.

Guy, J. 200I. The View Across The River: Harriett Colenso and the Zulu Struggle against Imperialism. Charlottesville, Oxford, Cape Town: University Press of Virginia, James Currey, David Philip.

Guy, J. I983. The Heretic: A Study of the Life of John William Colenso 1814-1883. Pietermaritzburg: University of Natal Press.

Heidegger, M. [1953] 1996. Being and Time: A Translation of Sein and Zeit. J. Stambaugh (trans.). Albany: State University of New York.

Henderson, P.C. 2005. Mortality and the Ethics of Qualitative Rural Research in a Context of HIV/AIDS. Anthropology Southern Africa, 28 (3\&4): 78-90.

Henderson, P.C. 2004. The Vertiginous Body and Social Metamorphosis in a Context of HIV/AIDS. Anthropology Southern Africa, 27 (I\&2): 43-53.

Henderson, P.C. 2003. Questions on Fostering: An Anthropological Perspective, pp. 9-3I. In S. Burman (ed.), The Fate of the Child: Legal Decision Making in South Africa. Cape Town: Juta.

Henderson, P.C. I999. Living with Fragility: Children in New Crossroads. Doctoral thesis, Department of Social Anthropology, University of Cape Town.

Hertz, R. I960. Death and the Right Hand. London: Cohen \& West.

Herzfeld, M. I992. The Social Production of Indifference: Exploring the Symbolic Roots of Western Bureaucracy. Oxford: Berg.

Holleman, J.F. I940. Die twee-eenheidsbeginsel in the sosiale en politieke samelewing van die Zulu. Bantu Studies, I4: 3I-75.

Hoosen, S. \& A. Collins. 200I. Women, Culture and AIDS: How Discourses of Gender and Sexuality Affect Safe Sex Behaviour. Paper presented at the AIDS in Context Conference, 4-7 April, University of the Witwatersrand, Johannesburg.

Hunter, M. 2007. The Changing Political Economy of Sex in South Africa: The Significance of Unemployment and Inequalities to the Scale of the AIDS Pandemic. Social Science Medicine, 64: 689-700.

Hunter, M. 2005. Cultural Politics and Masculinities: Multiple Partners in Historical Perspective in KwaZulu-Natal. Culture, Health \& Sexuality, 7 (3): 209223.

Hunter, M. 2002. The Materiality of Everyday Sex: Thinking Beyond 'Prostitution'. African Studies, 6I (I): 99-I20.

Hunter, M. I979. Reaction to Conquest: Effects of Contact with Europeans on the Pondo of South Africa. Cape Town: David Philip.

Hunter, N. 2005. An Assessment of how Government's Care Policy is Working in Practice: Findings from Kwa-Zulu-Natal. Working paper No. 42. Durban: HEARD.

Hunter, S. I990. Orphans as a Window on the AIDS Epidemic in Sub-Saharan Africa: Initial Results and Implications of a Study in Uganda. Social Science and Medicine, 3I (6): 68I-69o. 
Irigaray, L. I986. The Fecundity of the Caress, pp. 23I-56. In R.A. Cohen (ed.), Face to Face with Levinas. Albany: State University of New York Press.

Irigaray, L. I985. This Sex Which is Not One. C. Porter \& C. Burke (trans.). Ithaca: Cornell University Press.

Isikhugusethu Environmental Services (IES). 200I. Integrated Development Plan for the Okhahlamba Local municipality. http://www.devplan.kzntl.gov. za/.../Okhahlamba/Okhahlamba\%20IDP\%20Phase\%20I\%20Report\%20I/5

James, A. \& A. Prout. I990. Constructing and Reconstructing Childhood: Contemporary Issues in the Sociological Study of Childhood. London: The Falmer Press.

James, A., C. Jenks \& A. Prout. I998. Theorizing Childhood. Cambridge: Polity Press.

Jeffreys, M.D.W. I95I. Funerary Inversions in Africa. Archiv für Völkerkunde (Wien), IO: I45-I84.

Jewkes, R., L. Penn-Kekana, J. Levin, M. Ratsaka \& M. Schrieber. I999. 'He Must Give Me Money, He Mustn't Beat Me': Violence Against Women in Three South African provinces. Report, CERSA (Women's Health) Medical Research Council: Pretoria.

Jones, S. I993. Assaulting Childhood: Children's Experiences of Migrancy and Hostel Life in South Africa. Johannesburg: Witwatersrand University Press.

Junod, H. 1912. Life of a South African Tribe. Neuchatel, Switzerland: Attinger Bros.

Kalpeni, E., S. Craddock \& J. Ghosh. 2004. Mapping the AIDS Pandemic in Eastern and Southern Africa: A Critical overview. In HIV and AIDS in South African Cross-Sectional Study. Social Science and Medicine, 56: 25-134.

Kark, S.L. 1949. The Social Pathology of Syphilis in Africans. South African Medical Journal 23 (5): 77-84.

Kark, S.L. I950. The Influence of Urban-Rural Migration on Bantu Health and Disease. The Leech, 2I (I): 23-37.

Kittay. E.F. I999. Love's Labor: Essays on Women, Equality, and Dependency. London and New York: Routledge.

Kleinman, A. I997. Depression, Somatization and the 'New Cross-Cultural Psychiatry'. Social Science and Medicine, II: 3-IO.

Kleinman, A. I995. Writing at the Margin: Discourse between Anthropology and Medicine. Berkeley: University of California Press.

Kleinman, A. I988. The Illness Narratives: Suffering, Healing, and the Human Condition. New York: Basic Books.

Kleinman, A. I986. Social Origins of Disease and Distress. New Haven: Yale University Press.

Kleinman, A. \& J. Kleinman. I991. Suffering and its Professional Transformation: Towards an Ethnography of Interpersonal Experience. Culture Medicine and Psychiatry, I5: 275-302.

Kleinman, A., V. Das, \& M. Lock (eds.) I997. Social Suffering. Berkeley: University of California Press.

Krige, E.J. I936. The Social System of the Zulus. Pietermaritzburg: Shuter \& Shooter.

Kristeva, J. I987. Tales of Love. L.S. Roudiez (trans.). New York: University of Columbia Press. 
Kristeva, J. I982. Powers of Horror: An Essay on Abjection. L.S. Roudiez (trans.). New York: Columbia University Press.

Laband, J. 1995. Rope of Sand: The Rise and Fall of the Zulu Kingdom in the 19th Century. Johannesburg: Jonathon Ball.

Lambert, J. I995. Chiefship in Early Colonial Natal 1943-I879. Journal of Southern African Studies, 2I (2): 269-85.

Leclerc-Madlala, S. 2002. On the Virgin Cleansing Myth: Gendered Bodies, AIDS and Ethnomedicine. African Journal of AIDS Research, I: 87-95.

Leclerc-Madlala, S. 2000. Virginity Testing for AIDS Prevention: Consolidating the Gendered Epidemic. Paper presented at the I3th International Conference on AIDS, post-workshop on 'Social Inequality, Community Mobilization and HIV and AIDS Vulnerability', University of Natal, Durban, I5 July.

Leslie, D. I875. Among the Zulus and amaTongas: With sketches of the natives, their language and customs and the country, products, climate, wild animals, being principally contributions to magazines and newspaper. W.H. Drummond (ed.). Glasgow: Gilchrist.

Levinas, E. 200I. Is it Righteous to Be? Interviews with Emmanuel Levinas. J. Robbins (ed.). Stanford: Stanford University Press.

Levinas, E. I999. Alterity and Transcendence. M.B. Smith (trans.). New York: Columbia.

Levinas, E. I99I. Entré Nous: Thinking of the Other. B. Harshaw (trans.). New York: Columbia University Press.

Levinas, E. I989. Time and the Other, pp. 37-58. In The Levinas Reader. S. Hand (ed.). Oxford: Blackwell Publishers.

Levinas, E. I987. Time and the Other. R.A. Cohen (trans.). Pennsylvania: Duquesne University Press.

Levinas, E. I985. Ethics and Infinity: Conversations with Philippe Nemo. R.A. Cohen (trans.). Pittsburgh: Duquesne University Press.

Lévi-Strauss, C. I969 [1949]. The Elementary Structures of Kinship. Boston: Beacon Press.

Lévi-Strauss, C. 1967. The Effectiveness of Symbols, pp. 186-205. Structural Anthropology. C. Jacobson \& B. Grundfest Schoepf (trans.). New York: Doubleday Anchor Books.

Lingus, A. 2000. Dangerous Emotions. Berkeley, Los Angeles: University of California Press.

Lingus, A. I994. The Community of Those Who Have Nothing in Common. Bloomington, Indianapolis: Indiana University Press.

Lock, M. \& J. Farquhar (eds.). 2007. Beyond the Body Proper: Reading the Anthropology of Material Life. Duke University Press.

Lock, M. \& N. Scheper-Hughes. I987. The Mindful Body: A Prolegomenon to Future Work in Medical Anthropology. Medical Anthropology Quarterly, I (I): 6-4I.

Lund, F. 2007. Changing Social Policy: The Child Support Grant in South Africa. Cape Town: HSRC Press.

Lyotard, J.-F. 1988. The Differend: Phrases in Dispute. G. van den Abbeele (trans.). Minneapolis: University of Minnesota Press.

Marais, H. 2005. Buckling: The impact of AIDS in South Africa. Pretoria: University of Pretoria. 
Marcus, T. I999. Wo! Zaphela Izingane - It is Destroying the Children - Living and Dying with AIDS. Report prepared for the children in Distress Network (CINDI). Pietermaritzburg: CINDI.

Marks, S. 2002. An Epidemic Waiting to Happen? The Spread of HIV/AIDS in South Africa in Social and Historical Perspective. African Studies, 6I (I): I3-36.

Marks, S. I989. Patriotism, Patriarchy and Purity: Natal and the Politics of Zulu Ethnic Consciousness, pp. 216-234. In L. Vail (ed.), The Creation of Tribalism in Southern Africa. London, Berkeley: University of California Press.

Marks, S. 1986. The Ambiguities of Dependence in South Africa: Class, Nationalism, and the State in 2oth Century Natal. Johannesburg: Raven Press.

Marks, S. 1970. Reluctant Rebellion: The 1906-8 Disturbances in Natal. Oxford: Claredon Press.

Mattes, R. \& R. Manning. 2003. The Impact of HIV/AIDS on Democracy in Southern Africa: What Do We Know, What Do We Need to Know, and Why? Centre for Social Science Research Working Paper No. 34. Cape Town: Centre for Social Science Research, University of Cape Town.

Matsuda, M.J., C.R. Lawrence III, R. Delgado \& K. Williams Crenshaw (eds.). I993. Words that Wound: Critical Race Theory, Assaultive Speech, and the First Amendment. Boulder: Westview Press.

Mauss, M. I990. The Gift: The Form and Reason for Exchange in Archaic Societies. W.E. Halls (trans.). London: Routledge.

Mbembe, A. 2003. Necropolitics. Public Culture, I5 (I): II-40.

Mbembe, A. 200I. On the Postcolony. Berkeley: University of California Press.

Mbembe, A. \& D. Posel. 2004. A Critical Humanism. The WISER Review: 2.

McGregor, L. 2005. Khabzela: The Life and Times of a South African. Johannesburg: Jacanda Press.

Mda, Z. I997. Ways of Dying. Cape Town: Oxford University Press.

Means, R. \& R. Smith. I998. Community Care: Policy and Practice. Second Edition. London: Macmillan Press.

Meintjes H. \& S. Giese. 2006. Spinning the Epidemic: The Making of Mythologies of Orphanhood in the Context of AIDS. Childhood I3 (3): 407-430.

McAllister, P. 200I. Building the Homestead: Agriculture, Labour and Beer in South Africa's Transkei. Leiden: African Studies Centre.

McAllister, P. I997. Ritual and Social Practice in the Transkei, pp. 279-3I0. In Culture and the Commonplace: Anthropological Essays in Honour of David Hammond-Tooke. P. McAllister (ed.). Johannesburg: University of the Witwatersrand Press.

Merleau-Ponty, M. (I964) 2000. Phenomenology of Perception. C. Smith (trans.). London, New York: Routledge.

Merleau-Ponty, M. I964. Signs. R.C. McCleary (trans.). Evanston: Northwestern University Press.

Merleau-Ponty, M. I974. Phenomenology, Language and Sociology: Selected Essays of Maurice Merleau-Ponty. J. O’Neill (ed.). London: Heinemann.

Mills, E.A. 2004. HIV/AIDS and the 'Continuum of Care': An Ethnographic Study of Home-Based Care in KTC, Cape Town. Honours thesis. Department of Social Anthropology. University of Cape Town.

Mncube, F. I949. Hlonipha Language as Found among the Zulu-Xhosa Women. Master's thesis. University of the Witwatersrand. 
Moore, H. \& T. Sanders (eds.). 200I. Magical Interpretations, Material Reality: Modernity, Witchcraft and the Occult in Post Colonial Africa. London: Routledge.

Mpe, P. 200I. Welcome to our Hillbrow. Durban: University of KwaZulu-Natal.

Morgan, J. \& the Bambanani Women's Group. 2003. Long Life: Positive HIV Stories. Cape Town: Double Story Books.

Morar, N.S \& G. Ramjee. I997. 'Dry Sex' \& Douching Practices among Sex Workers at Truck Stops in KwaZulu/Natal. Health Systems Trust Update, 27: 56.

Morar, N.S. \& S.S. Abdool Karim. I998. Vaginal Insertion and Douching Practices among Sex Workers at Truck Stops in KwaZulu-Natal. South African Medical Journal, 88 (4): 470.

Msebenzi kaMacingwane. 1938. History of Matiwane and the Amangwane Tribe told by Msebenzi to his kinsmen, Albert Hlongwane. N.J. Van Warmelo (ed.). Ethnological Publications, Vol. VII. Pretoria: Government Printer.

Myer, L., L. Kuhn, Z.A. Stein, T.C. Wright Jr. \& L. Denny. 2005. Intravaginal Practices, Bacterial Vaginosis, and Women's Susceptibility to HIV Infection: Epidemiological Evidence and Biological Mechanisms. Lancet, 5: 786-94.

Nattrass, N. 2007. Mortal Combat: AIDS Denialism and the Struggle for Antiretrovirals in South Africa. Pietermaritzburg: University of KwaZulu-Natal Press.

Nattrass, N. 2004. The Moral Economy of AIDS. Cambridge: University of Cambridge Press.

Ndebele, N. I995. Recovering Childhood: Children in South African National Reconstruction, pp. 32I-33. In S. Stephens (ed.), Children and the Politics of Culture. Princeton: Princeton University Press.

Ngubane, H. I977. Body and Mind in Zulu Medicine: An Ethnography of Health and Disease in Nyuswa-Zulu Thought and Practice. London, New York, San Francisco: Academic Press.

Ngubo, T.E. I996. Home Care of Chronically Ill Persons in a Rural Community in Valley of a Thousand Hills. Master's thesis, University of Natal.

Niehaus, I. with E. Mohala \& K. Shokaneo. 2002a. Witchcraft, Power and Politics: Exploring the Occult in the South African Lowveld. London: Pluto Press.

Niehaus, I. 2002b. Renegotiating Masculinity in the South African Lowveld: Narratives of Male-Male Sex in Labour Compounds and in Prisons. African Studies, 6I (I): 77-97.

Nieuwenhuys, O. I994. Children's Lifeworlds: Gender, Welfare and Labour in the Developing World. London: Routledge.

Nkwe-Mabua, G.N. 2000. Community Home-Based Care for People Living with AIDS: Exploring Policy, Planning and Practice in KwaZulu-Natal. Master's thesis. University of Natal.

Ogden, J., S. Esim \& C. Grown. 2004. Expanding the Care Continuum for HIV/ AIDS: Bringing Carers into Focus. Horizons Report. June. Population Council and International Center for Research on Woman. Washington, DC. http:// www.popconcil.org/pdfs/horizons/xpndngcrentnm.pdf

Okhahlamba Municipality. 2006. Integrated Local Development Programme 2006-20I0. Mageba projects. http://www.kznded.gov.za

Okri, B. I99. The Famished Road. Cape Town: David Philip. 
Opie, I. and P. Opie. I969. Children's Games in Street and Playground. Oxford: Oxford University Press.

Opie, I. and P. Opie. (1959) I977. The Lore and Language of Schoolchildren. Oxford: Oxford University Press.

Petryna, A. 2002. Life Exposed: Biological Citizens after Chernobyl. Princeton: Princeton University Press.

Pile, S. I996. The Body and the City: Psychoanalysis, Space and Subjectivity. London. Routledge.

Phillips, A. 2002. Equals. London: Faber \& Faber.

Poland, M, D. Hammond-Tooke \& L. Voigt. 2003. The Abundant Herds: A Celebration of Nguni Cattle of the Zulu People. Vlaeberg: Fernwood Press.

Posel, D. 2004. Getting the Nation Talking about Sex: Reflections on the Discursive Constitution of Sexuality in South Africa since I994. Agenda, 62: 53-63.

Posel, D. 2005. Sex, Death and the Fate of the Nation: Reflections on the Politicisation of Sexuality in Post-Apartheid South Africa. Africa, 75 (2): I25-I53.

Platsky, L. \& C. Walker. I985. The Surplus People: Forced Removals in South Africa. Johannesburg: Ravan Press.

Plato. I985. The Symposium. W. Hamilton (trans.). Harmondsworth: Penguin Books.

Preston-Whyte, E.M. I995. 'Half-Way There': Anthropological and InterventionOrientated Research in KwaZulu-Natal, pp. 315-337. In H. Brummelhuis \& G. Herfdt (eds.), Culture and Sexual Risk: Anthropological Perspectives on AIDS. Langhorne: Gordon and Breach.

Preston-Whyte, E.M. I978. Families without Marriage: A Zulu Case Study. In J. Argyle \& E. Preston-Whyte (eds.), Social System and Tradition in Southern Africa. Cape Town: Oxford University Press.

Preston-Whyte, E.M., C. Varga, H. Oosthuizen, R. Roberts \& F. Blose. 2000. Survival Sex and HIV and AIDS in an African City, pp. I65-I90. In R. Parker, R. Barbosa \& P. Aggleton (eds.), Framing the Sexual Subject: The Politics of Gender, Sexuality and Power. Berkeley: University of California Press.

Radcliffe-Brown, A.R. I924. The Mother's Brother in South Africa. South African Journal of Science 2I: 542-55.

Radcliffe-Brown. A.R. I950. Introduction, pp. I-77. African Systems of Kinship and Marriage. A.R. Radcliffe-Brown \& D. Forde (eds.). Oxford: Oxford University Press.

Radcliffe-Brown. A.R. I933. The Andaman Islanders. Cambridge: Cambridge University Press.

Ramphele, M. 2002. Steering by the Stars: Being Young in South Africa. Cape Town: Tafelberg Publishers.

Rancière, J. 2004. The Politics of Aesthetics: The Distribution of the Sensible. G. Rockhill (trans.). London, New York: Continuum.

Raum, O.F. I973. The Social Functions of Avoidances and Taboos among the Zulu. Berlin: Walter de Guyter.

Ray, S., N. Gumbo, N. \& M. Mbizvo. I996. Local voices: What Some Harare Men Say about Preparation for Sex. Reproductive Health Matters, 7: 63-73.

Reid, G. \& L. Walker (eds.). 2005. Men Behaving Differently: South African Men Since 1994. Cape Town: Double Storey. 
Reutsch, D. I998. Imbiza kayibil' ingenambheki: The Social Life of Pots, pp. I9-37. In B. Bell \& I. Calder (eds.), Ukhumba: Aspects of Indigenous Ceramics in KwaZulu-Natal. Pietermaritzburg: Tatham Art Gallery.

Reynolds, P. I996. Traditional Healers and Childhood in Zimbabwe. Ohio: University of Ohio Press.

Reynolds, P. I987. Dance Civet Cat: Child Labour in the Zambezi Valley. London: ZED Press.

Reynolds, P. I995a. 'Not Known Because Not Looked For': Ethnographers Listening to the Young in Southern Africa. Ethnos, 6o (3-4): I93-22I.

Reynolds, P. I995b. Youth and Politics of Culture in South Africa, pp. 218-40. In S. Stephens (ed.), Children and the Politics of Culture. Princeton: Princeton University Press.

Reynolds, P. 2000. The Ground of All Making: State Violence, the Family and Political Activists, pp. I4I-I70. In V. Das et al (eds.), Violence and Subjectivity. Berkeley: University of California Press.

Robins, S. 2004. 'Long Live Zackie, Long Live': AIDS Activism, Science and Citizenship after Apartheid. Journal of Southern African Studies, 30 (3): 65I-672.

Ross, C.F. 2003. Bearing Witness: Women and the Truth and Reconciliation Commission in South Africa. London: Pluto Press.

Ross, C.F. 1995. Houses Without Doors: Diffusing Domesticity in Die Bos. Pretoria: The Human Sciences Research Council (HSRC). Cooperative Research Programme on Marriage and Family Life.

Russell, M. \& H. Schneider. 2000. A Rapid Appraisal of Community-Based HIV/ AIDS Care and Support Programmes in South Africa. Centre for Health Policy, Johannesburg.

Samuelson, L.H. [1928]. Zululand, its Traditions, Legends, Customs and Folklore. Marionnhill, KwaZulu-Natal: Mariannhill Mission Press.

Scarry, E. 1985. The Body in Pain: The Making and Unmaking of the World. New York: Oxford University Press.

Scheper-Hughes, N. I992. Death without Weeping: The Violence of Everyday Life in Brazil. Berkeley: University of California Press.

Scheper-Hughes, N. I992. Embodied Knowledge: Thinking with the Body in Critical Medical Anthropology. Paper delivered at the Social Anthropology Seminar, University of Cape Town, March i3th.

Scheper-Hughes, N. \& C. Sargent (eds.). I998. Small Wars: The Cultural Politics of Childhood. Berkeley: University of California Press.

Scheper-Hughes, N. \& M. Lock. I987. The Mindful Body: A Prolegomenon to Future Work in Medical Anthropology. Medical Anthropology Quarterly, I: 6-4I.

Schneider, D.M. I984. A Critique of the Study of Kinship. Ann Arbor: University of Michigan Press.

Schneider, H. 2002. On the Fault-Line: The Politics of AIDS Policy in Contemporary South Africa. African Studies, 6I (I): I46-i67.

Schonteich, M. I999. AIDS and Age: South Africa's Crime Time Bomb. AIDS Analyis Africa, Io (2): I-4.

Schonteich, M. 200I. A Generation at Risk: AIDS Orphans, Vulnerable Children and Human Security in Africa. Paper presented at a conference on Orphans and Vulnerable Children in Africa. Nordic Africa Institute, September 200 I. 
Scorgie, F. 2004. Mobilising 'Tradition' in the Post-Apartheid Era: Amasiko, AIDS and Cultural Rights in KwaZulu Natal, South Africa. Unpublished PhD Dissertation, University of Cambridge.

Scorgie, F. 2002. Virginity Testing and the Politics of Sexual Responsibility: Implications for AIDS Intervention. African Studies, 6 (I): 55-75.

Scorgie, F. 2006. Gender, Sexuality and Vaginal Practices in KwaZulu-Natal: Draft Report for WHO Co-ordinating Committee, GSVP Study: South African data.

Scully, W.C. I909. Fragments of Native History, iv: The amaHlubi and the amaNgwane I. The State, 2: 284-92.

Seekings, J. I995. Media Representations of Youth in the South African Transition, I989-1994. South African Sociological Review, 7 (2): 25-42.

Seekings, J. I996. 'The Lost Generation': South Africa's Youth 'Problem' in the Early I990s. Transformation, 29: I03-I25.

Seremetakis, C.N. (ed.). I996. The Senses Still: Perception and Memory as Material Culture in Modernity. Chicago, London: University of Chicago Press.

Seremetakis, C.N. I99I. The Last Word: Women Death and Divination in Inner Mani. Chicago, London: University of Chicago Press.

Sevenhuijsen, S.L. 2003. The Place of Care: The Relevance of the Feminist Ethic of Care for Social Policy. Feminist Theory, 4 (2): I79-I97.

Sevenhuijsen, S. I998. Citizenship and the Ethics of Care: Feminist Considerations on Justice, Morality and Politics. London and New York: Routledge.

Sevenhuijsen, S., V. Bozalek, A. Gouws \& M. Minnaar-McDonald. 2003. South African Social Welfare Policy: An Analysis using the Ethic of Care. Critical Social Policy, 23 (3): 299-321.

Sontag, S. 2002. Illness as Metaphor and AIDS and its Metaphors. London: Penguin Books.

South African Broadcasting Corporation (SABC) 7 February 2006. In the shadow of the mountain - Bergville script. SABC 3, 2Ih30. http://www.sabcnews.com specialassignment/shadowscript.html.

South African Census (SAC). 200I. Government Statistics of South Africa. Pretoria.

South African Census (SAC). 2006. Government Statistics of South Africa. Pretoria.

South African Department of Health Statistics (SADHS). I998. Pretoria.

South African Department of Health (SADOH). 200Ia. A National Guideline on Home-Based Care and Community-Based Care. http://www.doh.gov.za/docs/ factsheets/guidelines/homecare/index.html.

South African Department of Health (SADOH). 200Ib. An Enhanced Response to HIV and AIDS and Tuberculosis in the Public Health Sector - Key Components and Funding Requirements, 2002/03-2004/05. http://www.doh.gov. za/aids/docs/response.html.

South African Institute of Race Relations (SAIRR) I965. Factsheet Nr. 25/1965/ 2/3/65. Johannesburg: SAIRR.

Stadler, J. 2003. Rumour, Gossip and Blame: Implications for HIV and AIDS Prevention in the South African Lowveld. AIDS Education and Prevention, I5 (4): 357-368.

Stephens, S. (ed.) I995. Children and the Politics of Culture. Princeton: Princeton University Press. 
Stoller, P. 1995. Embodying Colonial Memories: Spirit Possession, Power and the Hauka in West Africa. New York, London: Routledge.

Sunter, C. \& A. Whiteside. 2000. AIDS: The Challenge for South Africa. Cape Town: Human and Rosseau, Tafelberg.

Surplus People Project, 1983. Forced Removals in South Africa, Vol. 4, Natal. Cape Town: Surplus People Project.

Taylor, C.C. I990. Condoms and Cosmology: The 'Fractal' Person and Sexual Risk in Rwanda. Social Science and Medicine, 3I (9): 1023-8.

Thornton, R. 2003. Flows of 'Sexual Substance' and Representation of the Body in South Africa. Seminar Paper presented at Wits Institute for Social and Economic Research (WISER), University of the Witwatersrand, Johannesburg, March 2002.

Tronto, J.C. I993. Moral Boundaries: A Political Argument for an Ethic of Care. New York \& London: Routledge.

Tronto, J.C. I995. The care ethic and welfare policy. Unpublished paper.

Thorrington-Smith, E, Rosenberg, M. \& McCrystal, L. 1978. Towards a Plan for KwaZulu: A Preliminary Development Plan, 2 vols. Ulundi: KwaZulu Government.

Turner, T. ı980. The Social Skin, pp. II2-40. In J. Cherfas \& R. Lewin (eds.), Not Work Alone. London: Temple Smith.

Turner, V. I969. The Ritual Process: Structure and Anti-Structure. Chicago: Aldine. Tyler, J. I891. Forty Years Among the Zulus. Boston: Congregational SundaySchool and Publishing Society.

United Nations AIDS (UNAIDS). 2004. 2004 Report on the Global AIDS Epidemic: 4th Global Report. Geneva: UNAIDS.

United Nations Development Programme (UNDP). 2005. Development Indicators, downloaded on 25 October 2005 from hhtp://hdr.indp.org/statistics/ data/indicators.cfm?alpha=yes

United Nations Children Fund (UNICEF). 2003. Africa's Orphaned Generations. New York: UNICEF.

Urdang, S. 2006. The Care Economy: Gender and the Silent AIDS Crisis in Southern Africa. Journal of Southern African Studies, 32 (I): I65-I77.

Uys, L.R. 2002. The Practice of Community Caregivers in a Home-Based HIV/ AIDS Project in South Africa. Journal of Clinical Medicine, II: 99-Io8.

Valentine-Daniel, E. I996. Charred Lullabies: Chapters in the Anthropography of Violence. Princeton: University of Princeton Press.

Vance, C. I997. Pleasure and Danger: Toward a Politics of Sexuality, pp. 327-335. In S. Kemp \& J. Squires (eds.), Feminisms. Oxford: Oxford University Press.

Van Gennup, Arnold. I96o. The Rites of Passage. Chicago: University of Chicago Press.

Van Zyl, M.C. I955. Luitenent-Goeweneur Martin West en die Natalse Voortrekkers. Archives Year Book. Vol.II.

Vilikazi, A. I965. Zulu Transformations: A Study of the Dynamics of Social Change. Pietermaritzburg: University of Natal Press.

Walker, L., G. Reid \& M. Cornell. 2004. Waiting to Happen: HIV/AIDS in South Africa. Cape Town: Double Story. 
Walker, M.U. I998. Moral Understandings. A Feminist Study in Ethics. New York and London: Routledge.

Walker, M.U. I999. Mother Time. Women, Aging, and Ethics. Lanham, MD: Rowman \& Littlefield Publishers.

Whiteside, A. \& C. Sunter. 2000. AIDS: The Challenge for South Africa. Cape Town: Human \& Rousseau, Tafelberg.

Web, C. \& J.B. Wright (eds.) I978. A Zulu King Speaks: Statements Made by Cetshwayo kaMpande on the History and Customs of his People. Pietermartizburg: University of Natal Press.

White, H. 2002. Tempora et Mores: Family Values and the Possessions of a PostApartheid Countryside. Journal of Religion in Africa, 31 (4): 457-479.

Wood, K., F. Maforah \& R. Jewkes. I998. 'He Forced Me to Love Him': Putting Violence on the Adolescent Sexual Health Agenda. Social Science and Medicine, 47: 233-42.

Wright, J.B. I97I. Bushman Raiders of the Drakensberg 1840-1870. Pietermaritzburg: University of Natal Press.

Wright, J.B. I989. The Dynamics of Power and Conflict in the Thukela-Mzimkhulu Region in the late 18th and early 19th Centuries: A Critical Reconstruction. Doctoral thesis submitted to Faculty of Arts, University of the Witwatersrand, Johannesburg.

Wright, J. \& C. Hamilton. I989. Traditions and Transformations: The PhongolaMzimkhulu Region in the Late I8th Century. In A. Duminy \& B. Guest. Natal and Zululand from the Earliest Times: A New History. Pietermartizburg: University of Natal Press.

Wright, J. \& A. Manson. I983. The Hlubi Chiefdom in Zululand-Natal: A History. Ladysmith: Ladysmith Historical Society.

Wright, J. \& A. Mazel. 2007. Tracks in a Mountain Range: Exploring the History of the uKhahlmaba-Drakensberg. Johannesburg: Wits University Press.

Young, I. M. I997. Intersecting Voices: Dilemmas of Gender, Political Philosophy, and Policy. Princeton: Princeton University Press.

\section{Newspaper Cuttings}

Cape Times. September 10, 2007: 4. Sipho Khumalo. We cannot apologise for our traditions.

Cape Times. August 20, 2007: 9. Steven Robins. Grounding Mbeki's AIDS stance in 'rationalities'.

The Daily News. August 25, 2007: 3. Amelia Naidoo. Leave our cultural practices well alone.

The Daily News. August I0, 2007: 7. Sally Scott. Virginity testing: is it right?

The Daily News. August 9, 2007, I2:00am. Madlala-Routledge relieved of her duties. http://www.iol.co.za

The Daily News. July 4, 2007: I. Bongani Mthembu. Reed dance festival faces bleak future.

The Daily News. II August, 2005. Bekho Madlala. Inkosi claims his kingdom. http://www.iol.co.za

The Mail and Guardian. June 23, 2007, I0:4I am. Ben Maclennan. Children's Bill approved by assembly. http://www.mg.co.za 
The Mail and Guardian. August I4, 2007, I2:08am. Michael Gregory. Mbeki vulnerable after sacking Nozizwe. http://www.mg.co.za

The Mail and Guardian. August Io, 2007, 7:30am. Madlala-Routledge was set up. http://www.mg.co.za

The Mail and Guardian. July 8, 2007, ir:59am. Niren Tolsi. My chiefdom for a kingdom. http://www.mg.co.za

The Mail and Guardian. July II-I7, 2003: 23. Achille Mbembe. Sex after liberation.

The Mercury. September 5, 2007: 2. Sipho Khumalo. KZN maidens defy Children's Act.

The Mercury. July 2, 2007: 4. Sipho Khumalo. Traditional leaders oppose KZN chiefs' claims.

The Mercury. July 6, 2007: 2. Sipho Khumalo. Zwelithini angered by 'king' claims.

The Mercury. July I7, 2007: 2. Sipho Khumalo. Hlubis stand firm on kingship.

The Witness. September 6, 2007: 2. Corruption at Home Affairs: DA blames department's 'absentee minister'.

The Witness. February 24, 2005. Chiefly dispute will soon be over, http://www. witness.co.za

The Witness. January 20, 2004: 3 .

The Witness. February 6, 2004: 3.

The Sunday Independent. September 2, 2007. James Macharia. Tutu lays blame for HIV/Aids deaths. http://www.iol.co.za

The Sunday Independent. December 4, 2005: 2. Xolani Mbanjwa. She's lost I6 of her progeny to the illness that cannot be named: a woman from KwaZuluNatal reflects on the loss of eight children and eight grandchildren.

The Sunday Tribune. July I, 2007: 2. Aziza Hlongwane. The Fight for Zulu Kingship. 


\section{Index}

abadala asebalala (the old ones who are sleeping, the ancestral shades) II7

abalele (those who are sleeping, ancestral shades) 62

abaphansi (those from below, ancestral shades) 49, 62, I47

abelungu (whites) II9

Abdool Karim, Q. 203

Abdool Karim S. 26

abject 26, 5I-3, 206

abjection 26, 53, 2I3, 2I5

Adorno, T. 68

adults $24,35,83-7$, I98

adversity 30, I27-8, I30, I32, I34, I36, I3 $8, \mathrm{I} 40, \mathrm{I} 42-4, \mathrm{I} 46, \mathrm{I} 48, \mathrm{I} 5 \mathrm{O}, 2 \mathrm{I} 3$

affliction $42-3,52,62-3,66,71,73$, IO9, I27

Africans 3I-2, 86, I05, I07-8, I25, 207, 2II-I3

AIDS deaths 86, 88, 210

AIDS education workshop I34-6, I4O-I, I44

AIDS epidemic $83,85,88$, I05, I87, I89, 208

AIDS-related deaths 60,84

AIDS-related illnesses 6I, 2I7

Akintola, O. 220

amadlozi (ancestral spirits) II4

amakhambi esintu ('curative herbs of mankind': 'indigenous' herbal medicines) 6I, IO6, I24

Amatikwe 60, 86-8, 95, 97, I0I, I03, I9O-I

children and youth of 87,89 , 9I, 93

amasotsha ozimba (soldiers-of-thebody, immune system) I4, IO7 amatshitshi (young prepubescent girls) IOO

Amit-Talai, V. 209 ancestral shades $20,46,62-3,93$,

І03, І16-І8, І23, I25, I29, I46-9,

I95-6, 2I4, 218

Anthropology Southern Africa I2

antiretroviral therapies I7, 2I, 29, 78,

I55, I6I, I67-70, I72-3, I75, I82-4,

I9I, 220-2

antiretroviral treatment I7, 29, I05, I44, I67, I70, I72, I88, 20I, 2I5,

219

apartheid state $29,34,84$, IO7, I53,

2II-2

Appadurai, A. I49

Aristotle 55

Ashforth, A. 203

Aspaas, H. 209

attention I7, 2I, 25, 27-8, 38, 68, 77, 80-I, 99, ІоІ-2, I47, I8I, I84, I98, $2 \mathrm{I} 4$

Atwell, D. 126

aunt 96-7, I67

Austin, J. 208

authority I02, I26, I70-I, I85

Barnett, T. 26, 209

Basaza, R. 209

Bataille, G. 54

Battaglia, D. 107

Bayly, C. 219

Beck, R. 204

beer I47, 2I 8

Belkinska, M. 2I5

Benjamin, W. I25

Bergland, A. 69, I34, 205-6, 2II, 2I58

Berger J. 2I4

Bhaba, H. 213

Bhengus 97-8, I3I, I34, I37, I45-6

Bible I22-3, I38, I62

Biehl, J. I7, 20I-2

bio-medicine I05, I2I, I23-4, I85, 2 I2

birth, giving $146-8$ 
blankets 48, 5I, 74, 77, 93, I45-6, I48, Butler, J. 208 I72, I74, 218

Bleek, W. 69

Bloch, E. 206

Bloch, M. 202

blood I3, 2I, 53, 55, 89, I25, I35, I3940, I68, I7I

bodily comportment 54

bodily practice 54

body I7, I9, 2I-4, 4I-3, 49-57, 70, 723, 77-9, 89-90, 106-7, II6, I38-40, I4 $8,203-8$

human 20, 26, 36, 106, 185

scientific 29

body fluids 53-4, I5I, 206, 208, 2I5

body image $52-3$

body maps 57

body's 5I, 54, I07, I73, I77, 20I, 209

body's permeability 54

body's workings Io6

boils (amathumbu) $138-40$

bones I2, I8-20, 22, 42, I23, I99

Bone of my heart 20

'Ngiyabonga Ukungithinta amathambo' ('Thank you for touching my bones') I8

Usala ngamathambo. (You are left with bones.) 42

Bongi Mazibuko 9I-3, 95, IO2

boys $63,74,87,94-5$, 99-100, Іо2, I20, I69, I7I, I74, I89

Borneman, J. 213-4

Bourdieu, P. 206

Braadvedt, H. 2I7

Bray, R. 84-6, 205

bride (umakoti) 99, I3I, I34, I36-7, I45-6, I95, I97, 216, 218, 220

bride's 2I6-7

bridewealth (ilobolo) I09, I3I, I34, I36-7, I45-6, I47, 213

Broad Reach I6, II9, I89, 2I2, 220

Brooks, E. 32

brooms I47-8, I95, 2I8

brother 22, 45-9, 56, 60, 9I-3, 97, I08, I32-4, I36, I39

brother-in-law 44-5

Bryant, A. 3I, 206, 2II, 2I7

Buber, M. 208

Busingatha I34-5, I38, I4O-I, I44

Busisiwe I7I-2

Cairns, E. 209

Callaway, H. 2II

Cape Town 32, 9I-2, II2

Cameron, E. 208

Campbell, C. 204

Canguilhem, G. I85

Caputo, J. 43

care (ukunaka) 24 carry, treat, rule (ukuphatha) 24 carry like an infant (ukuteta) ig touch, cure, reform (ukuthinta) 23

care work, home-based carers 23-5, 5I, I54, I60, I62, I75, I87, 208, 219, 222

caring 39, 6I, 94, I48, I76, I82-4, I87

Carsten, J. 202

cattle 3I, I3I, I37, I45-7, I90, I95-6, 204, 2I6-8, 220

Cebsile Mazibuko 9I-3, 95, IO2

Cebsile's father 9I

ceremonies 36, I29, I31, I37-8, I48, 2I 8

certificate III, I85

chest $42,88,9$ I, I55-6

child I9, 4I-2, 48, 55, 60-I, 85-6, II 8, I32-5, I37, I4I-2, I48, I57-8, I63, I9 $6,214-8$

Child Support Grant 35, IOI, II9, I93, 2OI, 2IO, 2I2

childhood I2, I9, 24, 84, 86

children I9, 47, 60-I, 64, 83-I03, I08-9, I47-8, I51, I58-61, I90, 209IO, 2I 2-3

million 209

mobility of 95

poor $37,86,88,201,209$-IO, 2I2 street 209

children-of-the-home $\quad{ }_{15} 8$

Children's Institute 203

child-rights discourse 84

Christ I63, I73

church 48, II4, I30, I32, I38, I6I-2

Church of Scotland Hospital I72

Clifford, J. I7

clinics I7, 44-5, 70-I, 76, I25, I33-4, I39-40, I54, I56-7, I60-2, I65-6, I69-7I, I 83, I88-9, 22I-3

clothes $77,89-90, \mathrm{I} 34, \mathrm{I} 37, \mathrm{I} 45$ 
coherence I9-20, 36, 42, 52, 57, I07

Colenso, J. 32

Coles, R. 209

communities IO, 27, 48, 60, 87, 89, 97, IOI, I03, II6, II9, I53-4, I6I, I66, I76-7

community-based care I53

community health workers 222

community workers IO, I65

compassion $64,66,80-\mathrm{I}, 87, \mathrm{I} 6_{5}$

condoms I4 5 , 22, 50, II9, I42, I5I

Congress of South African Trade Unions (COSATU) 35

Connolly, W. 43, 209

consolation 67,69

context 2I, 23-4, 28, 4I, 43, 49, 55, 73, 8I, 84-5, I26-7, I42, 202-3, 205-6, 209-IO

control 42, 52, 54-5, 76, 79, IO7, II2, II7, I2O, 207

conversations $44-6,52,66,74$, I05, I20-2, I44, I55, I57, I66, I88, I90, 203, 2I5, 220

Coombe, C. 209

COSATU (Congress of South African Trade Unions) 35

couple 38, I30-I

courage 97, I4O-I, I43

cousin II4-5

creation 63, 65, IOI, I03, I28, 207, 209-IO

Csordas, T. I8, 22, 26, 20I, 205-6

Dalley, G. I76

dancers 99-100

dances 99-IOI, I03, I33

dancing IOO, IO2, $2 \mathrm{I} 7$

danger 43, 54-5, 67-8, 83, I6I, 2I4

Daniel, M. 209

Das, V. I7-8, 69, 83, 202

daughter I8-20, 22-3, 43, 60, 62, 75, 88, 92, I09, III, I29-30, I37, 216

daughter-in-law I44, I46-7

Davidson, P. I27, 218

Davis, C. 18

death I7-2I, 35-7, 47-9, 52-4, 59-63, 66-9, 85-9, I27, I35-6, I40-3, I56-8, I72-3, I8I-2, 2OI, 2I6-I7

closeness of I27, I4I daughter's I8, 22

father's 3I, 9I, IO8

mother's 90-I

multiple 60, 209

parents' 85, 88, 92

preponderance of 59, I05

death rituals 69

de Boeck, F. 69, 210

Delius, P. 203

Dent \& Nyembezi I6, 46

Department of Health I70, 205, 2202

Derrida, J. 67-8, 8I

de Sade, M. 54

Desjarlais, R. I8, 202

Devisch, R. 203

(to) die of

the feet (izinyawo) 42

the head (ikhanda) 42

the chest (isifuba) 42

the stomach (isisu) 42

difficulties $30,92,98$, I03, I08, IIOI, I5I, I82, I85, 2I 5

dignity $72,76-7,80$, I4I

dimensions 37, I78, I8I-2

disability grants 45, 70-I, 76-7, 79, I56, I66

disease 9, 21-2, 24-5, 35-6, І05-6, І202, I28-9, I33, I35-6, I59, I6I-2, 20I, 208, 2I7

Disease-of-the-Mat (uZifo zoCansi) I4, 2I-2

diviner IO, I4, 35, 37, 62, 90, IO5, III, II3, II 8, I2I, I24, I29, I60, 2II

Dladlas 46, 48, I3I-2, I37, I45-6

doctor I4, 3I, 35, 44, 46, 70-3, I20-I, I33, I5I, I63, I68-70, I72-3, I83, I $87-8,22 \mathrm{I}-2$

documents I9, 98, III, I76, 20I, 2I9

DOH I53-4, 222

Doke, C. I6, 24, 2I4, 2I7

Dorrington, R. 26

Douglas, M. 53-5, 206

Dowling, T. 63, 208, 210, 216

Drakensberg II, 30-I, 33

dreams 62, 95, I08, II2-I4, II6, I75

drink 56, I73-4, 216, 221

Du Preez, M. 64

Durkheim, E. 69, 206 
earth $64,74,86$, IIо-3, II7-8, I22-3, I47, I64, 218

Emmaus Hospital 7I, II9, I72, I89, I9I, 206, 2I2, 222

employment 28, 34-5, 7I, I66, 2 I3

Ennew, J. 209

epidemic 26-7, 54, I20-I, I60, 203, $2 \mathrm{I} 2$

Erlmann, V. 2I5

Escourt 3I-2, 97-8

Etherington, N. 204

ethical relationships 79

ethics I2, 23, 25, 36-7, 43, 59, 77, 80I, I63, I77-9

ethics of ethnographic research 60 , $62,64,66,68,70,72,74,76,78$, 80

ethnographic research 9, 59-60, 62, $64,66,68,70,72,74,76,78,80$, 85,208

everyday $18,30,38-9,69,72,79,83$, 87 , IOI-2, I83, I85, 203, 220 everyday life I7, 2I, 26, 28, 30, 39, 6о-I, 69, 83, IO2, I25, I28, I48, I5O, I83-4

Eves, R. 207

exchange I0, I9, 23, 28, 30, 38, 55, 66, 8०, 93-4, I28, I42, I46-7, I49, I76-8

Fabian, J. I7, 69, 208

familiarity I60-I

families 2I-2, 26-7, 35-9, 43-9, 62, 66, 68, 7I, 75, 9I-3, 95-6, I23-4,

I44-5, I60-I, I8I-3

bride's 93, I3I, I45, I96-7

father's 89, 96-7

groom's I3I, I37, I96-8

husband's I30, 216

the space of $2 \mathrm{I}$

family members $45-6,49$, I60-I, I8I2, $2 \mathrm{I} 4$

Farmer, P. I20

farms, white-owned 3I-3, I08

Fassin, D. 28-9, 20I

father $48,55,64,87-91,93-4,96-7$, I08-9, I23, I29, I32, I34, I37, I39, 209-IO, 220-I

father-in-law I47

father's homestead 88, I30, I33 fault-lines 2I, 24, 54

fecundities I28, I49-50

Ferguson, J. 2I7

Fermé, M. 203

fertility 38, I28, I3I, I47, I49, 203, $2 \mathrm{I} 4,2 \mathrm{I} 8$

field 9-II, 27, 29, 33-4, 74, I3I, I74

fieldnotes 60-I

fieldwork 9, II, 35, 55

fight $2 \mathrm{I}-2,57,64,73,78-9$, I07, I2I

Findlayson, R. 210, 216

flesh I8-20, 26, 4I-4, 50, 70, II7, I3O, I40, I55, I67, 20I, 205

floor 48, 60, I42, I70, I72, 208

fluids $26,36,4$ I, 52-6, I34, I42, 206$7,215-6$

flying $\mathrm{I} 6$, II2

food $44,47,49,51,56,76-7,79$, 902, II4, II9, I23, I39, I47, IGI-2, 207

Fort Louis II4-5

Foucault, M. 54, I27, 20I, 205

Franklin, S. 202

friendship IO-I, 35, 37, 97, I31, I65, I89

funding $\mathrm{I} 6 \mathrm{I}, 220$

funerals 42, 46, 48, 59-6I, 68, I49, I6I, 2I5

gardens 97, 190, 220

gate $72,76,79$

gender 52, 54, I20, I46, I76, 203, 217

Geertz, C. 206

Geschiere, P. 27

Giese, S. 84-6, 222

gift-exchange in courtship and marriage $93, \mathrm{I} 28, \mathrm{I} 44, \mathrm{I} 49-50$

umabo (event in which gifts are given to groom's people from bride's family) I3I, I37, I45-6 umembeso (event in which gifts are given to bride from groom's family) I3I, I37, I45-6

symbolic significance of objects (see objects)

Gilman, S. $2 \mathrm{I} 4$

Goldman, L. 209-10

Goldstein, K. 22

Goody, J. 202

Goudge, J. 219

Grosz, E. 26, 52-5 
Gunner, E. II, 2I5

Guest, W. 32

Guy, J. 32, 2II

Hamilton, C. I2

Happy Mbhele 89-9I

healers I0, 23, 37, I05-6, Iо8-Iо, II2, II4-8, I20-22, I24, I26, I39, I60, I84, I89, 205, 2II, 2I7

healer narratives I08-9, III

healing 22, 24, I05-6, I09, II2-3, II6, I20, I38, I43, I8I, I85, 205

health $3 \mathrm{I}, 35,39,79$, I05-6, I20, I33-5, I57, I59, I66-7, I70, I75, I8I-3, I85, I89, I93, 205, 220-2

health system, formal I53-4, 222

health system, public I53, I55, I67, I69, 219-22

health workers $\mathrm{I}_{3}$

heart $20,74, \mathrm{I} 26, \mathrm{I} 3 \mathrm{I}-5, \mathrm{I} 64, \mathrm{I} 68,207$

heat $49,70,218$

heaven I22-3, I96

Heidegger, M. 2I7

help 90-I, II8, I24, I34-5, I39, I54, I6I, I64, I68, I74-5, 205

Henderson, P. 85, I20, 216

Hertz, R. 206

Herzfeld, M. 43

history I8, 28-30, 37, 88, I07, I25, I53, I63, I8I, 203, 205

HIV (Human Immunodeficiency Virus) 9-IO, I6, I8, 20-2, 25-30, $35,37-8,4 \mathrm{I}-5,49,55,57,60,62-5$, 68-9, 7I, 8I, 83, 85, 88, IоI-2, I057, II9, I2I, I23-4, I27-30, I33-6, I38, I40, I42, I44, I5I, I54-5, I59-62, I66, I68, I7I-2, I76, I8I, I83-5, I88 HIV, context of 9, I2, I7, 42, I06, I28, 2II

HIVAN (Centre for HIV Networking) 9-II, 35, I93, 220

Hlubi 3I-3

Holleman, J. 69, 2I7

home Io, 33, 44-5, 56, 59-60, 70-2, 76, 89-90, 94-5, 97-8, 102, I07, III-I5, II7, I2O-I, I23, I3O, I32, I34, I36, I44, I47, I53-4, I57-6I, I64-5, I67-9, I72-4, I77-8, I82, I84, I88, I9O-I, I98, 2I 6, 220, 222

home, new 97, 216 home, returned 70, 89, I09, I66, I74, 222

home area 44, 73, 85, II4, I54, I58, I65-7, I73, I9I

home-based care I53, I59, I63-4, I66, I76, 219

home-based care network I59, I65

home-based carers Io, I8, 24, 36, 389, 44, 66-7, 50-I, 60-I, 74-5, I29, I33-4, I39, I54-62, I66-7, I69-72, I75-6, I8I, I83-4, I87-9, I9I, 207-8, 2I7, 219-22

homesteads Io, 32, 36, 43-5, 47, 5I, 56, 59-6I, 63-4, 70-5, 77-9, 88, 9I4, 96, 99-100, I03, I06, I08, II5, I2O, I29-30, I35, I40, I47, I54, I579, I65-6, I69, I7I, I83, I88, I90, 202, 205, 2I4, 2I7-I $8,22 \mathrm{I}$

Hoosen, S. 203

horror 26,5 I, 53, 57, 78, IIо, I36 hospice I72-3

hospital I7-I8, 38-9, 45-6, 5I, 60, 70, 75-9, 89, I20, I33, I35, I39-40, I42, I53-4, I57, I60-3, I66, I69-70, I72, I74, I76, I8I, I83-4, I88-9, 205, 2I4, 2I7, 2I9, 22I-2

house 2I, 44-6, 56, 60, 62, 72, 75, 778, 88-90, 92, 94-5, I23, I39, I64, I74, 2 I9

household goods 197

Human Immunodeficiency Virus (see HIV)

husband 45, 48, 54, 56, I29, 137-9, I42, I44, I47, I54, I63, I66, I68, 207, 2I4, 2I6-7, 220

igciwane (germ, virus) I3-6

identity document(s), (ID(s)) 98, IOI, I76, I82

ill IO-II, 23-9, 36-38, 4I, 47, 50-I, 53, 56, 59, 6I, 66-7, 70-3, 79, 8I, 87, 89, 91, I05, I08, II3-4, II6, I25, I27-9, I33, I35-6, I38-9, I4I, I43, I5I, I53-4, I56-60, I62-4, I66-72, I74-6, I78, I8I-4, I87, I88, I96, 205-6, 208, 214, 219-22

illness 9-I0, I7-8, 20-7, 29, 37-9, 4I2, 44, 48-5I, 53-4, 56-7, 60-I, 63, 66, 70-80, 83, 88-9, 105-7, І09-Іо, II6, II9, I2I-5, I27-30, I33-6, I38, 
I43-4, I49, I5I, I55, I60, I62-3, I67, I75, I8I-5, I89, I9I, I99, 20I, 204, 208, 210, 212, 2I6-7

illness, lesisifo 9, 18, 42, 60, 63, 106, I09, II9, I25, I44, I55, I62, I8I, I83, I99

illness, Mashaya Bhuqe 62-3, I02, II9, I99

illness, new 7I, I25

illness and sociality 2I

illness, the politics of II9, I2I, I23

(i) mpepho (helichrysum miconiaefolium) 46, II3, I23, I48

immune system I4, 22, 106, I93, 195, 208-9

immune system, soldiers-of-the-body (amasotsha omzimba) I4, IO7

in-depth interviews 88, I90-I

individuals 9-IO, I7, 2I-2, 27, 36, 43, 5I-3, 65-6, 68, 98-9, II9, I2I, I43, I48-9, I54, I60-I, I70, I78, I8I-5, I87, I9I, 202, 206, 2I2

infant(s) I9, 4I-2, 55, 96, I46, I98

ingculaza (AIDS) I6, I35, I40

injection(s) I56, I7I

inoni (jelly-like medicine deployed by a woman to keep a man faithful) 56

interview 46, 6I-2, 89-90, 92, I09I3, II5, II7-8, I22-6, I3I, I33-4, I42, I46, I62-4, I67, I69, 2I8, 221

intimacy I7-2I, 27, 30, 32, 34, 4I, 42, 49, 52, 54, 59, 80-I, І27-8, І36, I42-3, I48, I82, I84, I88, I90, I96, 206

invasion Io6-7

inyanga (herbalist) 37, 76, 105, 108, III-3, II6, I2I, I38-9, 2 II

Irigaray, L. I9, 206-7

Isangoma (diviner), izangoma (plural) 62, 105

Isikhugusethu Environmental Services (IES) 34

isililo (mourning ceremony) 46-7, 567, I6I, 22I

isiZulu Iо-I, I6, 23, 35-6, 44, 50, 63, $74,88,90$, 100, 106, I30, I88, I90I, 195, 208, 2I7, 219

iziguli (ill people) 24

izintandane (orphans) 86, IOI, I89
James, A. 209

Jeffreys, M. 69

Jewkes, R. 2I3

Johannesburg I9-20, 44-5, 47-9, 704, 76, 78, 88-90, I05, I08-iI, II3, II5, I64, I68, I72, I99, 2I5

Jones, S. 9, 85

journeys IO, 23-4, 38, I08, I60-I, I73, I75, I79, I8I-5, 204

Junos, H. 202

jurisdiction $33, \mathrm{I} 26, \mathrm{I} 47$

Kalpeni, E. 203

Kark, S. 29

kingdom 31, 33, 50, I26, 221

kinship I2, I8, 2I, 27, 74, 88, 92, 202

kinship of bones I2

kin terms:

abakwekazi (relatives from the woman's side, a man's in-laws)

I37

abalingane (groom's people) I37

baba (father, husband) I3, I32, I39, I44

babomkhulu (grandfather) 94, I97

indodana (son) I3-4

malume (mother's brother) I4, 22

malumekazi (mother's brother's

wife) 46

mama (mother) 92

mamezala (mother-in-law) I46,

I47

mamkhulu (grandmother) 90, 97 I97

mamncane (mother's younger sis-

ter) 46, 90, I97

mzala (cousin) II4-5

sisi (older sister) 132

umkhwenyana (betrothed, son-in-

law) I5, I34, I48

kipitile (term used for casual relationship) 44

Kittay, E. I77

Kleinman, A. I8, 24, 20I-2

Krige, E. 69, I46, 2II, 2I4, 2I6-8

Kristeva, J. 26, 36, I3I-2, I34, I50, 206, 2I4-5

KwaZulu-Natal 9, II-2, I7, 27, 33, 35, 85, 91, Іог, II3, I6I, I88, I9I, 2034, 2II, 2I3, 2I5, 2I8-9, 222 
Ladysmith 3I, 46, 49, 73, 76, 89, I29, I32, I66, I73-4, 206

Ladysmith Hospital I4, 49, 76, I66, 206

land I4, 30-3, 74, I08, II9, I9O-I, 204 Langalibalele $32-3$

language $\mathrm{I7}, 22-3,30,35,65-7,84$, 86,88 , IOI, I03, I30, I45, I57, I77, 205, 208-9

learning 60, 67, 80-I, IO9-II, II3, I6I, I68, I75, 205

learnt $23,35,37-8,60,75,90,108-2$, I29, I40-I, I6I, I70

Leclerc-Madlala, S. I2O, 204, 2I5-6

letter I6, 7I, 75, 90, 97-8, II5, I39

Levinas, E. 25-6, 37, 64-5, 77, 8I, I4I, I5O, I78, 208, 2I4, 2I7, 2I9

Levi-Strauss, C. 206, 2I3

Lingus, A. 37, 66-7, 206

living 9, I7-I $8,20,23,27,30-5,37$, $44,46,48,53,59,60,63-5,68-70$, $76,85,87-9$, 9I-5, I03, I05-6, II2-3, II6-7, I2I, I23-4, I28-9, I46, I48-9, I7 $8,208,2 \mathrm{I} 4,2 \mathrm{I} 7-8$

living circumstances $7,37,87,89$, 9I, 93

living waters II2

living world I8, I03

local clinic 44-5, 79, I09, I7I, 208

local hospital 3I, 38, I69, I87

Lock, M. 26, 202, 206

loss I8, 47, 49, 63, 79, 85-6, 94, 102, I08, 206

love 9, I2, I8-9, 22-3, 26, 49-50, 62-3, $85,97, \mathrm{I} 27-30, \mathrm{I} 34, \mathrm{I} 36, \mathrm{I} 38, \mathrm{I} 40$, I42-44, I46, I48, I50-I, I64, I97, 207, 213-15

love charms I97, 207

lovers $28,36,38,56$, I20, I35, I50, 207, 2I4-5

Lund, F. 2I2

Lyotard, J. 68

Makhosi I67, I82

Maluju! (Exclamation to stop a fight.) 63-4

Mandla Shabalala 5I, 59, 66, 70-8I, I55, I66

death 76

employers 7I
Manson, A. 32

Marais, H. I53, I77, 220, 222

marijuana 34-5, I96

Marks, S. 29, 204

marriage 22, 32, 38, 69, 93, I02, I09, I20, I27-3I, I33, I36-8, I4I-9, I5I, I95-6, I98, 202, 213-8

marriage beast(s) I37, I96

Mashaya Bhuqe (The Great Annihilator) 62-4, 102, II9, I99

maternal uncles I4, 22

Matsuda, M. 208

Mattes, R. 205

Mauss, M. I49, 219

Mazel, A. 3I-5, 204

McAllister, P. 2I 8

Mbembe, A. 20I, 203, 206, 2I3

Mda, Z. I27

Means, R. 176

meat $147-8,196,218,22 \mathrm{I}$

medication 2I-2, 29, 46, 5I, 62, 67, 73-4, I2I, I33-4, I2I, I33-4, I53-5, I57-8, I6I, I67, I69-72, I75, I85, I88, 212, 219-222

medicinal plants Io6, Io8

medicinal practices on the body ukubhema (to smoke the body) Io6

ukuchatha (enemas) Io6, I20 ukuchela (to sprinkle medicines) Io6

ukugcaba (rubbing medicine into small incisions on the body) 106, I20

ukugquma (steaming the body with herbal infusions) Io6

ukuphalaza (to vomit) Io6, I20, 205

medicines I6, 6I, 70, 72, 76, 106, I09, III-II3, II7-8, I2I, I24, I35, I38-40, I48, I72, I84-5, I95, I97-8, 205, 2II, 2I 6

meetings 36, 5I, 97, 99, I29-30, I43, I59, I6I, I64, I66, I72, I83, I87-8, I9O-I, 2I7, 22I

Meintjes, H. 84-6

members 28, 35, 45-6, 49, 5I, 62, 8I, 87-8, 95-6, 99, Іог, І36, I46, I57, I60-I, I66-7, I70, I8I-3, I87, I89, I9I, 204, 2I4, 2I7, 220, 223 
Merleau-Ponty, M. 22, 26, 205, 208 metaphors 2I-22, 55, 74, I06-7, I28, I44-5, I96

Mills, E. I53, I76, 220

Mncube, F. 2IO

mobility, pain of $95-96$

money I4, 32, 44, 53, 70-I, 73-4, 76-8, 90-I, 96, 98, I09, II4, II9, I38-9, I45-6, I56, I6I, I67, I74-5, 205, 220

Moore, H. 203

Morar, N. 2I5

Morgan, J. 57

mortality $7, \mathrm{I} 2,25,34,50,59-60,62$, 87,208

mother I8-9, 22, 44-9, 55, 60-2, 64, 67, 70-5, 77-80, 86, 88-94, 96-8, I09, II2, II5, I23, I29, I32, I34, I40, I44, I46-7, I58, I64, I9I, I95, I97, 207, 209, 2IO, 2I4-5, 2I8 mother, the I9, 55, 60, 62, 64, II5, I40

mother-in-law I29, I44, I46-7, I95, I97

mountains IO, 3I-2, 36, 45, 92, 94, I0०, І07-8, ІІ2, ІІ8, I45

mourning I7-8, 20, 30, 36, 6I-2, 689, 158, 196, 207, 209, 220

Mpe, P. 20

Msinga I6I, I67-75, I88-9, 2I8, 220, 222

multiple deaths 68,85

Myer, L. 2I5

names 9-10, І2, 36, 63, 68, 99, Іо2, I08, III, I23, I37, I88, III, I23, I37, I88, 2I4, 2I6, 220

Nattrass, N. II, 28-9, 205

neighbourhoods 2I, 36, 38, 59, 6I, IOI, I57, I65, I87-9, I9I, 2I2, 2I7, $22 \mathrm{I}$

neighbours 22, 32, 6I-2, 66, 68, 73, 83, 9I-2, 95, I02, I44, I47-8, I6I-2, I64, I7I, 202, 208, 2IO, 2I 8 , 220-I

Ndebele, N. 209

ngculazi (AIDS) 63-4

Ngubane, H. 52, 55, I7I, 205, 207 , 2II, 2I 6-8

Ngube, T. 219

Ngwane I7, 3I-34, I09, I9I, 2II-2
Niehaus, I. 203-4

Nieuwenhuys, O. 209

Njabulo Bhengu I27, I29, I29-I38, I40-I45, I48-5I, 209, 2I6-7

Nkosinathi Dladla 44-50, 53, 56-7, 7I, I54, I6I, I8I

death of $44-5,47,49$

brother-in-law 44-5

mother 44-5, 48, 7I

sister 46

Nkwe-Mabua, G. 2 I9

Nonhlanhla Duma I05, II3-25, I30, I33, I73-5, I84, I89

nouns $195-8$

Ntombikayise Dladla I27, I29-38,

I40-5, I47-5I, 2I4-7

mother $145-7,218$

father I36-7, I46, I48, 218

words I3I, I35, I49, 2I 8

Ntuthuko Hadebe I05, I08-I3, II6, $\mathrm{I} 20-4, \mathrm{I} 84,2 \mathrm{I} 2-3,2 \mathrm{I} 8$

nurses $39,5 \mathrm{I}, 76$, I38, I43, I8I

objects $38,43,49,93, \mathrm{I} 28, \mathrm{I} 44-5$, I48$8,205,219$

Ogden, J. 222

Okhahlamba 9, II-2, I7-24, 27-3I, 345, 37-8, 4I-2, 44, 46-7, 52, 54-5, 6I, $65,68,70,83,86-8,94-6,98-9$, I05-8, II2, II8-2I, I26, I34, I38, I45, I49, I54-5, I60-I, I64-7, I697I, I73, I8I, I84, I87-9I, I93, 202, 205-7, 219-23

Okri, B. 86

ontologies 53

Opie, I. 209

orphanhood 84, 86, I89, 209

orphans I2, 35, 37, 64, 83-8, IOI-2, I89, I93, I97, 209-IO, 22I

patients I0, 24, 29, 38, 44, 5I, 60, 68, 70, 75, IO9, II9, I2I, I23, I29, I534, I57-8, I60-3, I65-70, I72-3, I75-

6, I79, I83-4, I87-9, I96, 205, 208, 219-222

pace $29,37,66,72,80$, I 24

pain 20-I, 25, 54, 59, 65, 67-8, 70, 723, 76-7, 79-8I, 85, 88, 95-7, IOI-2, I09-IO, I36, I4I, I5O, I55, I63, 203 , $2 \mathrm{IO}$ 
pain, personal 85 , IOI

paper 84 , III

parents IO, I2, 35, 37, 60, 83-9, 92-3, 96, 98, IOI-2, I29, I33, I36, I46, I60, I83-4, I87, 209-IO, 2I3, 2I 8 biological 83, 86, 88, 209

particularities 49, 68, IOI, 202, 204, 206

partners 4I, 52, I5I, 207, 2I4, 216

paying attention $66,77,80-\mathrm{I}, 83$, IO9-IO, II7, I98

person 9, I3-5, I9-25, 38, 4I-2, 48-50, 59-6г, 65-7, 80, 86, Iо6-7, IIо, ІІ34, II6, I22-5, I29, I30-32, I38, I402, I48-50, I53-4, I58-60, I63-4, I69, I73, I75, I79, I8I, I85, I9O-I, 2OI, 205, 208, 2II-I2, 2I7-I9, 22I22

personhood 20, 79, I27, I63, I97

Petryna, A. I8, 20I

Philips, A. 80

photographs I29, I74

Phumzile Ndlovu Io, 35, 37, 44-7, 5I, 56, 59-61, 70-5, 77-8I, І19, І23, І30, I48, I54, I56-7, I64, I70-I, I83, I879, I9I, 2I2

physical death 136

Pietermaritzburg 32, 35, 45, 187, 219 Pile, S. 43

pills 76, I23-4, I40-I, I56, I68-7I, I735

plasterer I08-9, III-2

poets 25-6, I9I

poetry $30,36,63,187,195$

politics II9, I2I-3, I26, I 83

politics of illness, the II9, I2I, I23

Poland, M. 2I7

pollution 26, 36, 4I, 44, 5I, 54, IO6, I48, 204-5, 2I5-6

population 3I-2, 34, IO6, 2I2

Posel, D. II, 208

pots I48, 2I 8

poverty $29,83-5,87-8,95, \mathrm{I} 27, \mathrm{I} 58$, I69, I7I, I75, 20I, 203, 205

power $23-5,27,33,43,54,63$, I05, I08-9, III, II3, II8, I20-I, I28, I34, I43-4, I5O, I75, I84, 2I2, 2I5 praise names (izihasho) 63, 99-Ioo pray II3, I2I, I38, I42, I62
Preston-Whyte, E. 9, 203, 213

Pretoria 34

prison I62-3, 22I

procreation 38, I42, I47-5I, 207

projects $20,84,189,220$

pursuit $37-8,83-8,90,92,94-6,98$, I00-2, I38, I44, I57, I75, 205, 209, 2I4

Radcliffe-Brown, A. 69, 202, 213

rain 6I-2, II2-3, I69

Ramphele, M. 85

Raum, O. $2 \mathrm{I} 6$

Ray, S. $2 \mathrm{I} 6$

recognition I9, 23, 25, 27, 30, 38, 43, 5O-I, 80, I28, I44, I5I, I57, I75, I77-

8, I8I-2, I85

reconciliation 69, 2I2, 2I8

Reid, G. 29, 204

relatedness 2I, 24-5, IO2, I83, 202

relationships IO, 2I, 24-8, 30, 36, 4I, $49,52,59,70,79,83,93,95$, I00, Iо6, II6, I28, I33, I47, I55, I57, I6o, I65, I76, I78, I8I, I83, 203 , 207-8, 213-5, 218, 222

intimate $27,2 \mathrm{I} 3$

sexual 28, 52, 2I 3

relationships of intimacy 2I, 25

relatives $13,32,46,49,61,66,74,83$, 90-3, 96, I02, I3I, I37, I69, I95,

207-8, 210, 2I 4 , 2I 8

request $49,73,80$, II 8

resonance $25-6,43,93,97$, IO7, III, II 8 , I3I, I46, I48-9, 201

resources $39,43,45,53,87, \mathrm{I} 38, \mathrm{I} 53$, I57, I59, I6I-2, I69, I76, I82-3 responsibility 24-5, 37, 6I, 64-6, 8I, 94, I08, II9-20, I23, I47, I53, I63, I77-8, 208, 2I7, 2I9

Reutsch, D. 2I 8

Reynolds, P. II, 5I, 83, 209

rituals $28,30,36,48,68-9,74,96$, I03, I28, I48, I67, I95, 2I2, 2I 8

roads $73-4$, IIO-3, I58, I73, I90, I99

Robins, S. I2, 29, $2 \mathrm{I} 2$

Ross, F. II, 69, 83

rural homes 42-3, 53-4, IIо, II6, I78, I8I, I96

Russel, M. 219 
SABC 34, I93

SAC I93

SADHS I93, 2I3

SADOH 193

SAIRR I93

Samuelson, L. 2I7

Scheper-Hughes, N. 20I, 206, 209

Schneider, D. 202, 219

Schonteich, M. 209

school Io, 34, 47, 89-92, 96-IоI, I089, III, I64, I74, I76, I90, 2I2

Scorgie, F. II, 28, I20, 215-6 sediments of death (of grief) $6_{3}$

Seekings, J. 209

self $20,24-5,38-9,43,52,54,65-66$, 68, 77-8, 96, 99, І03, І27, I32, I48, I50, I53, I65, I8I-2, I90

semen 52-3, 55, I34, 207

Seremetakis, C. I8, 69, 205

Sevenhuijsen, S. I76-8, 2I7

Sex I4-5, 2I, 27, 38, 54-5, I2O, I22, I2 8, I30, I32-4, I42, I48, I5I, I98, 203, 207, 2I4-6, 2I8

sexual risk 203

sexuality 26-8, 52, 54, 74, I20, 203-4, 206-7, $2 \mathrm{I} 4$

shades $23,46,55,62-3,74,93,96$, I03, I09, II6-8, I2I, I23, I25, I29, I34-5, I46-7, I60, I95-6, I98, 206$7,2 \mathrm{I} 2,2 \mathrm{I} 4-6,2 \mathrm{I} 8$

Shaka 3I, 33, 64

spirit house 94

Sibongile 46-50, I58, I72-5

silence $25,43,5 \mathrm{I}, 57,59,66-7, \mathrm{I} 28$,

I43, I55, I60, I8I, 202, 210

sister 22, 44, 9I-2, 94, I08, I83, 22I

Sizakhele Mdunge 70

skills Io, 48, 99, IO9-II, I82

skin I8, 20, 4I-2, 49-5I, 70, 72-4, 789, 90, I32, I48, I96, 208

sleep 9I, 93, II5, II7, I32, I48, I74 social life $20,22-3,37,4 \mathrm{I}, 53,56,62$,

8I, I20, I50, I65, I76-7, I8I, 202, $2 \mathrm{I} 3$

social worlds 30, 4I, 53, 69, 84-6, 95, I06, I29, 201, 204, 209 disintegration of 84 sociality I8, 2I, 25, 42, 50, 54, 65-6, I75, I8I, I83-4, 205

solidity $20,36,53-4,57,60$ son I3-5, 3I, 43, 48, 56, 60, 62, 7I-2,

$74,76-7,79,93,108, \mathrm{II} 4, \mathrm{I4} 6-8$,

I57, I7I-2, 202, 205

son-in-law I5, I46-8

songs 35, I33, 2I4-5

Sontag, S. 50, 53, I06

Sophie's mother's death 88

spaces 2I, 25, 4I, 54, 62, 99, IOI, IO3, II6, II9, I65, I8I-3, I89, 202

speech 23, 25, 59-60, 66-7, 122, 136, I4O, I43, I57, 208, 210, 22I

Stephens, S. 209

Stoller, P. 204

stories 9-10, 24, 28, 34, 36-7, 5I, 55, 6o, 65, 77, 89, 94-5, 98, 103, II9, I39, I67, I8I-2, I89, 208, 2I 8

streets I9, III

subjectivity 203

subjectivities 24-5, II5, I65

subjects 25, 52, 90, I26, I84

substances 26, 52-3, I06, I35, I49, 207, 215, 219

Sunter, C. 26, 205

support group meeting $156,173-5$, 207

support groups I55, I88, 2I7

surprise $25,35,45,65,67,78,80$, $\mathrm{I} 43, \mathrm{I} 46$

sustain 2I, 30, 32, 86, I49, I66

TAC (Treatment Action Campaign) 29, I87, I93

Taylor, C. 165

taxis II9, I6I, I73-4, I89

temporalities I28-9

Tholi I55-6

Thornton, R. 207

Thulani Hadebe 93-4, I00, 210

touch I9, 23-4, 4I, 44, 49-50, 67, 72, II7, I24, I5O, I8I, I9 8

touch, non-violent 49

towns 3I-2, I08, II9, I29, I9I

tradition(s) I05, I08

transport 44, 7I, 73, 96, II4, I6I, I67

treatment I7, 27, 29, 4I, 44, 46, 6I, 69, 76, 78-9, 97, І05, І16, І23, І33, I35, I38, I40, I42-4, I5I, I54, I60, I66-7, I70-74, I84, I87-9, I93, 20I, 205, 2I2, 2I5, 2I7, 2I9, 222

Trinity Njoko Busisiwe I3, 2I 
Tronto, J. I77, 2I7

truth I7, 29, I32-3, I44, I64, 2I2

Turner, V. 206

Tyler, J. 69

ubuntu (humanity) 25, 92, 94, I49, I 53,165

Uitval I73-4

ukhamba (clay pot) $\quad \mathrm{I} 47-8$

ukugana ('informal' marriage) 93

ukuhlonipha (to respect) 99, I44, 210, $2 \mathrm{I} 6$

ukunakisisa (to pay attention) Io9

ukunyana (to recoil in disgust) 50,76

ukuqoma (a girl choosing a lover) IOI, I2O, I3O, 215

ukusisela (looking after animals that have been loaned to one) 94

ukuthwala (marriage through abduction) 93

ukuzula emgwaqeni (to wander the roads, to be sexually promiscuous) 74

ukwelapha kwesintu (curative herbs of humankind) 106

umabo (event in which gifts are given to groom's people from bride's family) I3I, I37, I45-6

umembeso (event in which gifts are given to bride from groom's family) I3I, I45-6, 2I7

umkhongi (marriage negotiator) I30I, I37, I45, 2 I4

umlahlankosi (Buffeldooring tree, Ziziphus mucranata) 94

umphako (food for the road) 44

umsamo (altar to the ancestral shades) 62, I47-8, 2 I 8

umsebenzi wocansi (work-of-the-mat, sex) I3O, I33, I48

umshanguzo (ARVs) I4I

Urdang, S. I77, 220, 222

UNAIDS I93, 209

UNICEF I93, 209

Uys, L. 2I9

Valentine-Daniel, E. 69, 201

Vance, C. 2I4

Van Gennep, A. 206

Vilikazi, A. 2I7-8 violence I7, 2I, 25, 27, 54, 64-5, 83-5, IIO, I59, I78, 202-3, 2I3

virus I5-I6, 2I, 42, 45, 50-2, 57, 63, 88, IOI, IO7, II9, I2I-3, I34-5, I40, I42, I5I, I60, I7I, I93, I95, 205-8, $2 \mathrm{I} 6$

voice $20,62,70,79,86$, I05, І1з-6, I3I-2, I75

volunteers I54, I58, I62, I65-6, I70-I, I87

vulnerabilities $24,37,65,77,80,162$, I84

vulnerable children 35, 87-8, I87, I93

Vusi Hadebe 93-4, I00, 210

Vuyiswa $70,72-4,76-8,80$

Walker, L. 29, 33, I77, 204, 2I3

waste, ill person's body 208

water 22, 44, 55, IIO-I3, II8, I2I, I23,

I34-5, I44, I69, I73-4

Web, C. 3I

wedding I34, I36-9, I4I, I44-6, I48, I5O, I97, $217-8$

welfare $35,108,229,187,201,217$, 22I

White, H. 206

Whiteside, A. 26, 205, 209

wife $45-6,54,6$ I, 90, 92-4, 97, I09, III, I2O, I29-3I, I36, I4I, I43, I589, I97, 2I4, 2I6, 22I witness 22, 38, 49, 53, 66-7, 80-I, 87, I50, I54, I58, 205-6, 2II

Witness, The 205-6, 2II

Wits (University of Witwatersrand) I2, 33, 35, I66

Wood, K. 213 woman I9, 44, 47, 55-6, 60-I, 70, 72, $74,76,92,95-8$, I05, I23, I32, I35, I43, I46, I48, I55, I57-60, I63, I67, I69, I7I-2, I76-7, I9I, I96, 205, 2I5, 2I 8,222

women 22, 25, 27-8, 32-3, 35, 38, 46, 50, 54-7, 6I-3, 73, 85, 93, II9-20, I27, I34, I36-7, I43-4, I46, I48, I54-5, I59, I65-6, I74-8, I84, I88, 203-4, 207, 212-8, 220, 222 work in medical anthropology 38 work-of-the-mat (umsebenzi wocansi, sex) I30, I33, I43 
workers Io, 32-34, 76, 97, I63, I65, I75-6, 215, 222

migrant 76, 215, 222

social 97

workshop 96, IOI, I34-6, I38, I40-I, I44, I9I

world I8, 20-22, 30, 37, 4I-2, 47, 49-

$50,54,57,59,65-6,72-3,75,79,8$ I, 94, 99, I03, I05-6, IO9-II, II5-6, I22-3, I44, I49-50, I60, I63, I65, I83-4, 20I-3, 205, 209, 2I3, 22I

Wright, J. 3I-5, 204

Wright, J. and Mazel, A. IO4

Xoli Bhengu 96-8

young girls 28, IOO, II9-20, I95

young woman I9, 44, 70, 72, 74, 92, 98,167, I69, I7I-2, I9I younger brother I4, 2I, 9I-2, I39

younger children $46-7,49,62$, 90-I, IOO, I97

younger sister $46-7,49,62$, 90-I, IOO, I97

youth I2, 37, 63, 83-6, 98-100, I02, I87, I89-90, 209

Zanele Mchunu Io, 35, 87, 97-9, IоI, I03, I87, I89-9I

Zinhle Vilakazi 44-5, 47, 50, 59-6o, I54-64, I66-7, I69-70, I72-5, I83, I88, 220

husband I64, I66

words $162-3$

Zulu I2, I6, 3I, 33, 36, 53, 63-4, 69, 74, 76, I02, I09, II2, I2I, I24, I9I, 205, 207, 2IO, 2I2, 2I5-6 